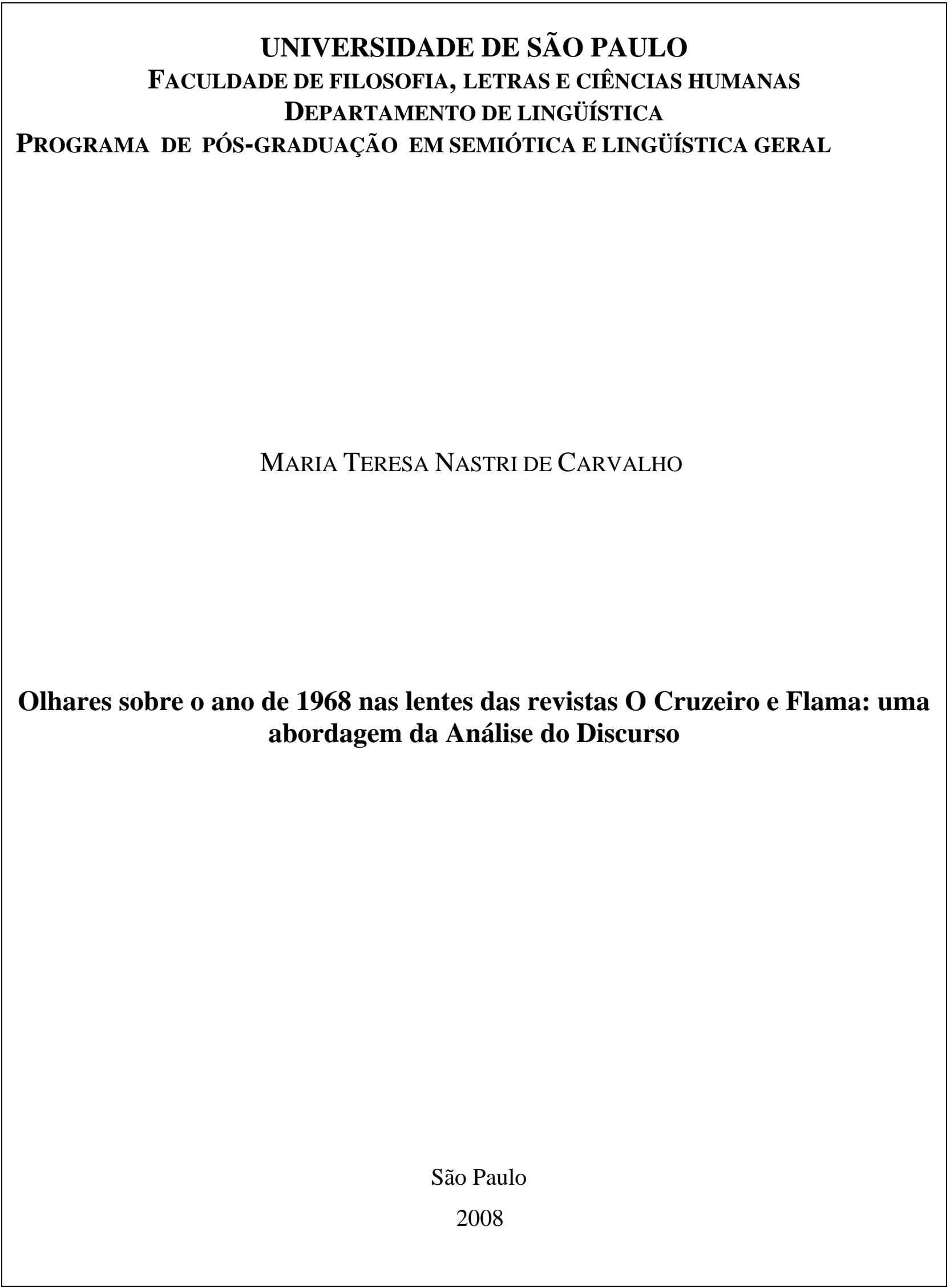




\author{
UNIVERSIDADE DE SÃO PAULO \\ FACULDADE DE FILOSOFIA, LETRAS E CIÊNCIAS HUMANAS \\ DEPARTAMENTO DE LINGÜÍSTICA \\ PROGRAMA DE PÓS-GRADUAÇÃO EM SEMIÓTICA E LINGÜÍSTICA GERAL
}

\title{
Olhares sobre o ano de 1968 nas lentes das revistas O Cruzeiro e Flama: uma abordagem da Análise do Discurso
}

\section{MARIA TERESA NASTRI DE CARVALHO}

Tese de Doutorado apresentada ao Programa de Pós-Graduação em Semiótica e Lingüística Geral do Departamento de Linguiística da Faculdade de Filosofia, Letras e Ciência Humanas da Universidade de São Paulo, como exigência para obtenção do título de Doutor em Lingüística.

Orientadora: Profa. Dra. Irenilde Pereira dos Santos

São Paulo

2008 
Autorizo a reprodução e divulgação total ou parcial deste trabalho, por meio convencional ou eletrônico, para qualquer meio convencional ou eletrônico, para fins de estudo e pesquisa, desde que citada a fonte.

Carvalho, Maria Teresa Nastri de

C325 Olhares sobre o ano de 1968 nas lentes das revistas O Cruzeiro e Flama: uma abordagem da Análise do Discurso/ Maria Teresa Nastri de Carvalho; orientadora: Irenilde Pereira dos Santos. - São Paulo, 2008.

211 f.+ anexos.

Tese (Doutorado- Programa de Pós-Graduação em Lingüística. Área de Concentração: Semiótica e Lingüística Geral) -Departamento de Lingüística da Faculdade de Filosofia, Letras e Ciências Humanas da Universidade de São Paulo.

1. Análise do Discurso - 2. Ideologia - 3. Polifonia - 4. Mídia Impressa - 5. Ano de 1968. I. Título 


\section{Maria Teresa Nastri de Carvalho}

\section{Olhares sobre o ano de 1968 nas lentes das revistas O Cruzeiro e Flama: uma abordagem da Análise do Discurso}

Tese de Doutorado apresentada ao Departamento de Lingüística da Faculdade de Filosofia, Letras e Ciências Humanas da Universidade de São Paulo, como exigência para obtenção do título de Doutor em Lingüística.

Área de pós-Graduação: Lingüística

Área de Concentração: Semiótica e Lingüística Geral

Orientadora: Profa. Dra. Irenilde Pereira dos Santos

\section{BANCA EXAMINADORA}
Profa. Dra. Irenilde Pereira dos Santos
DL - FFLCH/USP
Orientadora

\begin{tabular}{rr}
\hline & $\begin{array}{r}\text { Prof (a) Dr(a): } \\
\text { Instituição }\end{array}$ \\
\hline & Prof (a) Dr(a): \\
Instituição \\
\hline \\
\hline Prof (a) Dr(a): \\
Instituição \\
\hline \\
Prof (a) Dr(a): \\
Instituição
\end{tabular}


Ao Wagner, a melhor descoberta de minha vida. Pela sua calma, pela sua doce voz, pelo seu carinho, pelo seu amor. Declaro aqui o meu grande amor, respeito e admiração. 


\section{AGRADECIMENTOS}

Agradeço a Deus por ter me guiado nestes quatro anos e por ter me cercado de tantas pessoas boas

Aos meus pais pelo incentivo de sempre, por me encorajarem em todos os momentos e por entenderem essa minha longa ausência

Às minhas muito queridas irmãs, pela cumplicidade, por serem minhas grandes e eternas amigas, agradeço também aos meus cunhados, por fazerem minhas irmãs felizes, assim como as minhas sete paixões, que são os meus sete sobrinhos

Agradeço ao Wagner pela leitura cuidadosa de minha tese, por muitas opiniões fundamentais ao longo de todo o doutorado e por ter aberto mão de sua vida e partido para Portugal comigo, enfim, por fazer minha vida mais feliz

Ao Mané e a Cynira, meus sogros, pela atenção e por também entenderem minha ausência, agradeço a Laila por sua doçura e por ser minha amiga

Aos colegas do GPDG (Grupo de Pesquisas em Dialetologia e Geolingüística da USP), parceiros muito importantes, ao longo desses anos, com quem convivi bons momentos. Em especial ao Clézio, por nossas andanças, por nossas crenças, por nossas eternas alianças de amizade e de companheirismo

Agradeço, especialmente, minha orientadora, a profa. Dra. Irenilde Pereira dos Santos, não só pela orientação, mas também por ter depositado confiança na minha pesquisa, pelo cuidado, pelo carinho, pela presença constante e por tantas leituras, releituras e encaminhamentos, sem os quais não teria conseguido chegar até aqui

À banca da qualificação, ao prof. Dr. Luiz Antônio Ferreira, pelas valiosas contribuições e

à profa. Dra. Neusa Maria Oliveira Barbosa Bastos, professora desde a graduação, orientadora do mestrado, pelas contribuições fundamentais durante o exame de qualificação, em 2006, amiga nos momentos difíceis, porto seguro de tantos momentos... e musa inspiradora de muitos anos

A CAPES pela bolsa sanduíche concedida para estágio no exterior

À profa. Dra. Olívia Maria Ferreira Gonçalves Figueiredo, minha co-orientadora da Universidade do Porto, pela importante contribuição no período de estágio em Portugal 
Aos professores e funcionários do Departamento de Lingüística, área de concentração: Semiótica e Lingüística Geral

Aos amigos da Faculdade Taboão da Serra, Marcelo, por ter se mostrado mais amigo e menos coordenador e à Cássia, amiga e atenta revisora

À Margarida, amiga portuguesa, pela grande ajuda na terra de Pessoa

Às amigas do coração, Carla, Nancy, Andréia. 
CARVALHO, Maria Teresa Nastri. Olhares sobre o ano de 1968 nas lentes das revistas O Cruzeiro e Flama: uma abordagem da Análise do Discurso. São Paulo, 2008. 211 f. Tese (Doutorado em Semiótica e Lingüística Geral) - Faculdade de Filosofia, Letras e Ciências Humanas da Universidade de São Paulo.

\section{RESUMO}

Este trabalho teve por objetivo geral verificar a relação do homem com a sociedade, por meio da linguagem. Assim, partiu-se para revistas de variedades, que circulavam no Brasil e em Portugal em 1968 - O Cruzeiro e Flama. Especificamente, objetivou-se detectar a polifonia, bem como o dialogismo que perpassavam os textos das mencionadas revistas, a fim de que se conseguisse depreender o ethos das publicações, assim como o ethos dos colaboradores das revistas, além do ethos das próprias pessoas envolvidas nos fatos noticiados. A polifonia detectada não proporcionou, entretanto, a depreensão da ideologia de cada uma das publicações, o que pode demonstrar um posicionamento de obediência

frente à censura imposta pelos dois países naquele ano ou mesmo retratar opções e interesses dos proprietários de $\mathrm{O}$ Cruzeiro e da Flama. A pesquisa realizou-se com base teórica na Análise do Discurso de linha francesa e, não de forma central, mas consubstanciada também por teorias linguiísticas que enfocam a interação e em autores que, de algum modo, apresentam-se afinados com alguns preceitos da AD, em especial Bakhtin, sendo bastante importantes também Charadeau e Maingueneau. A confluência dessas teorias propiciou (re) ver um ano tão marcante tanto em termos de mudanças comportamentais, como em termos políticos. Por meio das revistas e amparo da teoria apresentada, traçou-se um percurso historiográfico do ano, nos dois países. Levando em conta as categorias citadas, a análise possibilitou uma visão mais ampla de cada uma das revistas. Concluiu-se que muito do ano de 1968, no tocante ao aspecto político, foi apresentado de modo parcial e não contou com um fio ideológico claramente definido tanto numa quanto em outra publicação. 
CARVALHO, Maria Teresa Nastri. Olhares sobre o ano de 1968 nas lentes das revistas O Cruzeiro e Flama: uma abordagem da Análise do Discurso. São Paulo, 2008. 211 f. Tese (Doutorado em Semiótica e Lingüística Geral) - Faculdade de Filosofia, Letras e Ciências Humanas da Universidade de São Paulo.

\begin{abstract}
This research aims to check the relation between men and society through language. Thus, we have analyzed fait-divers magazines which used to be published both in Brazil and Portugal in the year of 1968- such as "O Cruzeiro" e "Flama". Specifically, we have tried to detect the polyphony and the dialogism in those magazines so as to reveal the ethos of the issues, of the writers of such magazines and also of the people involved in the narrated facts. However, the polyphony did not detect the ideology of each publication which can show a certain obedience to the censorship imposed by the two countries in that time or else it can show options and interests of the owners of the magazines mentioned above. The research was based not only on the theory of French discourse analysis but also on some auxiliary linguistic theories which focus on the interaction and on certain authors like Bakhtin, Charaudeau and Maingueneau. The study of these theories has offered a chance to (re) view the importance of such a remarkable year in terms of changes of behavior, and also in terms of politics. Through the magazines it was possible to trace a historical route of that year in both countries. Taking into account the categories cited, the analysis provided an ample vision of each magazine. We have concluded that much of what happened in 1968 had not been clearly ideologically defined in both publications.
\end{abstract}

Key words: discourse analysis, ideology, polyphony, press, the year of 1968. 
CARVALHO, Maria Teresa Nastri. Olhares sobre o ano de 1968 nas lentes das revistas O Cruzeiro e Flama: uma abordagem da Análise do Discurso. São Paulo, 2008. 211 f. Tese (Doutorado em Semiótica e Lingüística Geral) - Faculdade de Filosofia, Letras e Ciências Humanas da Universidade de São Paulo.

\section{RÉSUMÉE}

Ce travail a eu comme objectif général de vérifier la relation de l'homme avec la société, par le moyen du langage. De cette façon, on est parti vers les magazines de variétés qui circulaient au Brésil et au Portugal en 1968 - «O Cruzeiro » et « Flama ». Spécifiquement on a eu comme objectif détecter la polyphonie, ainsi que le dialogisme qui parcouraient les textes des magazines mentionnées, pour que l'ethos des publications réussissait à se déprendre, ainsi que l'ethos des collaborateurs des magazines, au-delà de l'ethos de propres personnes qui font partie des faits informés. La polyphonie détectée n'a pas pourtant entraîné la deprise de l'idéologie de chaque publication, ce qui peut démontrer un positionnement d'obéissance devant la censure imposée par les deux pays dans cette annéelà ou même décrire des options et intérêts des propriétaires de «O Cruzeiro » et de «Flama ». La recherche a été conduite avec une base théorique sur l'Analyse du Discours de ligne française et, non de façon centrale, mais consolidée aussi par des théories linguistiques qui abordent l'interaction, et sur des auteurs qui, d'une certaine manière, se présentent liés à quelques préceptes de $\mathrm{AD}$, surtout Bakhtin, étant Charadeau et Mainguenau très importants aussi. La réunion de ces théories a possibilité (re)voir une année extrêmement remarcable aussi en termes de changements comportementaux qu'en termes politiques. Par le moyen des magazines et du support de la théorie présentée, on a tracé un parcours historiographique de l'année dans les deux pays. En considérant les catégories citées, l'analyse a possibilité une vision plus large de chaque magazine. On a conclut qu'une grande partie de l'an 1968, en ce qui concerne l'aspect politique, a été présentée d'une façon partiale et n'a pas compté avec une ligne idéologique clairement définie dans les deux publications.

Mots-clés: Analyse du Discours, Idéologie, Polyphonie, Média Imprimé, An de 1968. 


\section{SUMÁRIO}

Introdução

Capítulo 1 -

O Panorama Sociopolítico da Era Salazar, em Portugal, e da Ditadura Militar no Brasil....21

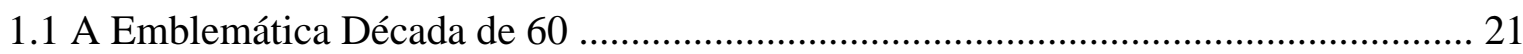

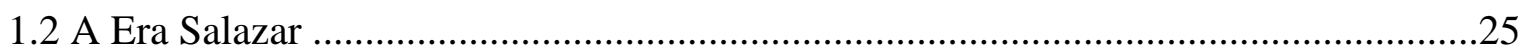

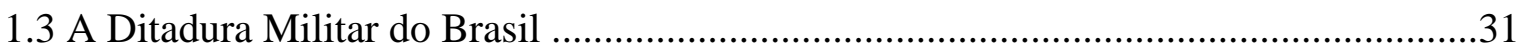

Capítulo 2 -

Ideologia e Mídia Impressa

2.1 A Ideologia e seus variados conceitos ....................................................................

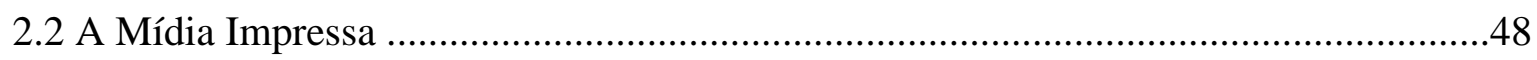

Capítulo 3 -

A Análise do Discurso, as teorias lingüísticas que enfocam a interação e os Gêneros do Discurso .55

3.1 A Análise do Discurso em seus primeiros momentos ...................................................55

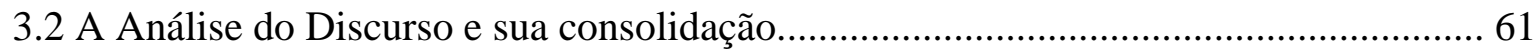

3.3 A Sociolingüística Interacional e alguns aspectos relativos aos Gêneros do Discurso.. 70 3.4 Os possíveis laços entre a Análise do Discurso e as teorias que enfatizam a interação..75

Capítulo 4 -

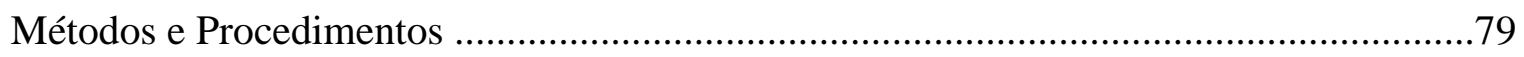

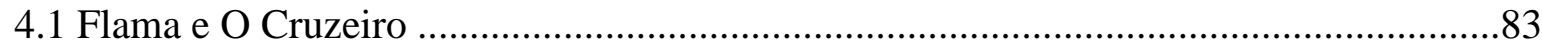

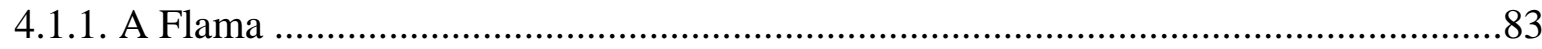

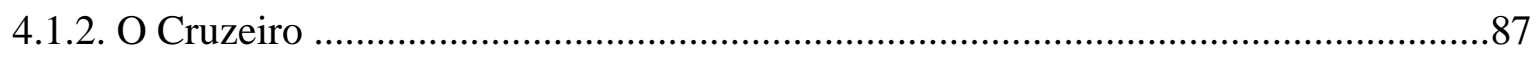

4.2. O Olhar da Análise do Discurso .......................................................................... 
Capítulo 5 -

Análise das revistas

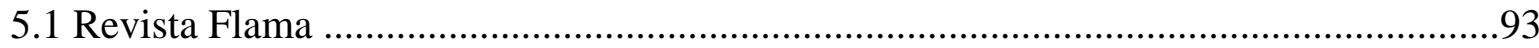

5.1.1 Flama, número 1049, ano XXIV, de 12 de abril de 1968. ........................................93

5.1.2. Flama, número 1068, ano XXV, de 23 de agosto de 1968. .....................................115

5.1.3. Flama, número 1072, ano XXIV, de 20 de setembro de 1968 .................................132

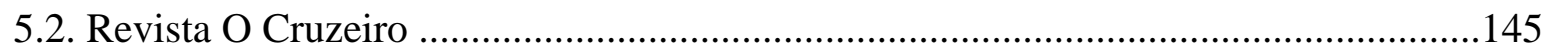

5.2.1. O Cruzeiro, número 14, ano XL, de 06 de abril de 1968. ..........................................145

5.2.2. O Cruzeiro, número 31, ano XL, de 03 de agosto de 1968. .....................................168

5.2.3. O Cruzeiro, número 37, ano XL, de 14 de setembro de 1968...................................183

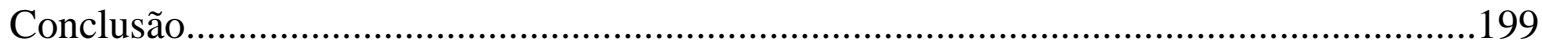

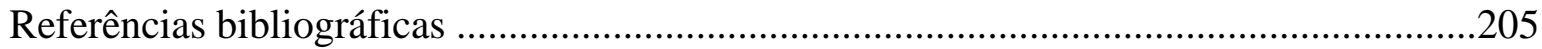

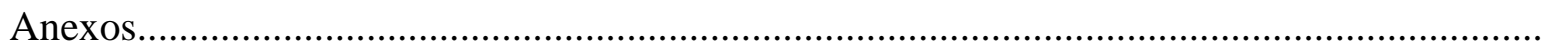




\section{INTRODUÇÃO}

Refletir sobre o homem, inserido na sociedade, é recorrente em incontáveis estudos, sob diversos olhares. Tal relação parece ser inesgotável. Assim sendo, no campo científico, estudiosos da área das humanidades, vêm, enfaticamente, há muito tempo, explorando aspectos que propiciam analisar detidamente o ser humano vivendo e convivendo em uma dada comunidade.

O homem estabelece variadas relações com o meio, pela linguagem. Essas relações são amplas e envolvem a tríade homem-linguagem-sociedade num constante agir e, de algum modo, quando o homem age, essa ação se reflete na sociedade e esse reflexo ocorre por meio da linguagem. Ou seja, ao agir, o homem se expressa de algum modo e, ao fazê-lo atinge/afeta, em maior ou menor grau, indivíduos ou instituições que compõem uma sociedade. Contudo, parece haver realmente um ciclo, pois assim como o homem age e a sociedade sofre/recebe, é destinatária da ação do homem; este também é destinatário de ações/sanções da sociedade. É uma cadeia em que há a ação do homem no meio e viceversa. Nas palavras de Brandão (2003, p. 25)

Eu sou eu na medida em que interajo com o outro. É o outro que dá a medida do que eu sou. A identidade se constrói nessa relação dinâmica com a alteridade.

Esse encadeamento de ações e reações em que ora homem, ora sociedade são agentes ou receptores nos interessa, quando analisado sob o viés da imprensa que muito filtra e/ou maquia, de acordo com interesses oriundos de instituições, de grupos detentores do poder, que podem contar com segmentos da mídia, muitas vezes mostrando-se aliada a eles.

Toda essa relação do homem com o meio se dá, também, pela atuação política, própria do ser que vive em sociedade. Aspectos externos influenciam direta ou indiretamente a vida privada de qualquer ser. A linguagem de que faz uso uma determinada comunidade recebe claramente interferência, levando-se em conta a época, assim como o contexto sociopolítico. Leite (2005, p.194), respaldada por Aléong, afirma: 
... a língua é um fato social, um veículo simbólico que, portanto, não pode ser analisada fora do ambiente em que se atualiza. A premissa dessa perspectiva é a de que a língua obedece a normas sociais e esquemas de comportamento e só pode ser estudada a partir de sua inserção na sociedade, na cultura de que faz parte.

Para a elaboração desta pesquisa, alicerçamo-nos especificamente por teorias da Análise do Discurso de Linha Francesa e por alguns conceitos de Bakhtin, que convergem para questões exploradas pela Análise do Discurso. Buscamos, ainda, compreender os conceitos de ethos, em especial, sob a perspectiva de Maingueneau e aspectos relativos aos Gêneros Textuais, ${ }^{1}{ }^{1}$ já que nosso corpus contou com uma grande variedade de gêneros.

Estudos importantes de Análise do Discurso, releituras e pesquisas a partir das obras fulcrais de Bakhtin, aspectos relativos ao conceito de ethos, de Aristóteles a uma abordagem na Análise do Discurso, como na Semiótica e trabalhos sobre os Gêneros Textuais vêm sendo realizados há décadas, tanto na Europa, nos Estados Unidos como no Brasil por renomados pesquisadores. Apesar de todo esse arcabouço bibliográfico, não deixamos de lado a nossa pilastra capital que é a própria Lingüística e, ao longo de nosso estudo, tivemos sempre em conta analisar nos textos a materialidade lingüística e esta, em consonância com as teorias acima apresentadas, deram-nos uma direção. Assim sendo, bem amparadas teoricamente, passamos a olhar detidamente um específico período.

Numa era de rigidez imposta por regimes totalitários, os textos escritos, sobretudo os jornalísticos, de alguma forma, apresentam-se ou ideologicamente comprometidos com o regime, ou ideologicamente censurados, limitados ao que é possível, em termos de expressão.

Nossa hipótese central era levantar marcas mais ou menos explícitas, tanto no que diz respeito à estrutura textual, ao gênero textual, à matéria escolhida como capa, ao assunto central da edição impressa, como o recorte feito por órgãos da imprensa, especificamente revistas semanais que apontassem para uma opção pautada nos interesses e ideologias, mas que, de algum modo, permitem que o leitor construa um ethos da revista.

\footnotetext{
${ }^{1}$ Em virtude de estar cada vez mais na ordem do dia o trabalho com os Gêneros, inúmeros são os estudiosos que pautam suas pesquisas no assunto. Entretanto, alguns teóricos o qualificam como Gêneros Textuais, outros, seguindo mais de perto as teorias de Bakhtin se referem aos Gêneros do Discurso e alguns fazem referência a Gêneros discursivos. Para nós, que não trataremos centralmente do tema, usaremos indistintamente as denominações.
} 
Desde o início de nossa pesquisa, almejamos proceder a uma analogia entre as publicações brasileiras e as portuguesas, que circulavam semanalmente, que fossem bastante lidas e tivessem um caráter de revista de atualidade. Num primeiro momento, conseguimos exemplares das revistas portuguesas: "O observador", "Vida Mundial", "Século Ilustrado" e "Flama". Entre as brasileiras, lançamos mão, de início, às revistas "Realidade", "Visão", "Fatos e Fotos" e "O Cruzeiro". O segundo passo, com o intuito de delimitar mais nosso trabalho, foi escolher uma publicação que, embora denominada como sendo de variedades, tivesse um enfoque também nas amenidades, sem deixar de explorar questões relativas ao contexto social e político. Para nós, isso serviria até para mensurar o peso dado pelas mesmas a assuntos de pouco reflexo social ou político e outros de maior relevância nesses aspectos, quer num contexto nacional ou no internacional

As portuguesas "O observador", "Vida Mundial", "Século Ilustrado" foram descartadas, por terem um aspecto mais formal, um público-alvo provavelmente mais masculino e por terem um espaço pequeno para assuntos menos densos, em detrimento de questões políticas, econômicas e culturais. Por motivo semelhante, também descartamos as brasileiras "Realidade" e "Visão". A "Fatos e Fotos" foi excluída por motivo contrário, o quase nulo espaço para assuntos mais sérios, de cunho mais social e político.

Em relação às publicações, tínhamos por hipótese que as revistas destinadas a um público mais amplo e que abordassem também temas até certo ponto menos relevantes, na medida em que se destacavam as pessoas que estavam na mídia, na época, assim como assuntos de cunho mais político, tanto do próprio país, como notícias sobre política internacional, permitir-nos-iam dados mais concretos, a ponto de detectarmos a polifonia nesses meios impressos, bem como sua ideologia.

Nessa medida, de forma a investigar nossa hipótese, tomamos por corpus, as revistas de generalidades, a saber: Flama, em Portugal e O Cruzeiro, no Brasil revistas que sintetizavam nossas expectativas e que tinham espaço claro para as mulheres, estas que na década de 60 passaram, de fato, a conquistar mais o espaço na sociedade. Imaginamos que um paralelo entre a situação sociopolítica impressa pelo regime Salazar em Portugal e a situação vivida no Brasil com a ditadura militar podem ser um tipo de termômetro desse emaranhado de relações, em que a linguagem usada em tais periódicos pode refletir o poder instituído. 
Dentre tal gênero de revistas há, no entanto, algumas que aparentam uma maior ou menor preocupação com a situação sócio-político-histórica. Algumas, provavelmente, apesar da censura, tentavam, por meio de uma linguagem mais elaborada, quiçá mais enigmática, lacunar e/ou metafórica, levar questões a um público inquieto com o regime imposto. Outras publicações visavam a um público menos preocupado com tais questões e selecionavam não só a maneira de abordar um tema, mas o próprio tema, seguindo um caminho menos politizado.

São essas diferenças, verificáveis desde a capa dessas revistas, a artigos veiculados, bem como a maneira de interagir com seu público, que nos propiciarão respostas a certas hipóteses levantadas. Parece-nos não só justificável como bastante fértil um estudo acerca de prováveis influências na concretização de enunciados lingüísticos presentes em revistas de variedades, em circulação regular tanto em Portugal, como no Brasil, nos anos 60 do século XX. A era Salazar, no estudo em questão restrito ao ano de 1968, como o regime militar brasileiro, também delimitado ao mesmo ano de 1968, no que se refere a certos meios de comunicação, no caso as revistas analisadas, devem apresentar um papel significativo nas mudanças de determinadas marcas lingüísticas, bem como na manutenção de outras.

Não se pode negar que construções lingüísticas, orais ou escritas, estão subscritas a uma determinada ideologia. Do ponto de vista mais delimitado, referimo-nos a uma ideologia da revista e, no aspecto mais abrangente, nossa referência diz respeito à ideologia do contexto social, político, histórico e cultural na qual está inserida.

Em momentos de pouca abertura política, típicos de governos autoritários, órgãos da imprensa que não compactuam com tal situação, necessitam, para abordar temas, de bastante perspicácia para não serem censurados. Por outro lado, mesmo os meios que comungam com o "prescrito" pelo poder devem proceder a uma seleção não só de assuntos abordados, como também a maneira de os tratar, resguardados por um discurso, se não claro, ao menos implicitamente em concordância com a "ordem do dia".

Quando falamos de textos jornalísticos, não delimitamos um ou outro gênero, sabemos da existência de variados gêneros, inseridos no discurso jornalístico. Embora não seja foco desta pesquisa questões relativas aos gêneros textuais, estes permearão nosso estudo, já que nosso corpus, composto de variados gêneros textuais encontrados 
comumente em revistas, serão explorados. O fato é que no nosso cotidiano vemo-nos atravessados por uma grande variedade de gêneros textuais, nas mais diversas situações. A respeito disso, Lonardoni (2004, p.13) afirma:

... verifica-se a estreita relação do texto com o universo real do indivíduo que, a cada dia, se vê às voltas com novas marcas, símbolos de produtos, textos de diferentes modalidades que acabam incorporando ao seu cotidiano, como elementos fundamentais à sua existência, como a água ou a alimentação básica.

No entanto, independente da inserção de determinados textos em um ou outro gênero do discurso, no que se refere aos textos inseridos num âmbito jornalístico, Lonardoni (2004) faz menção ao afirmado por outros pesquisadores, no que concerne à idéia de que o maior desafio para o jornalismo como campo de conhecimento é a configuração de sua identidade como objeto científico. Tal identidade do jornalismo está relacionada à autonomia jornalística que, para o citado autor, passa pela sistematização dos processos sociais que dizem respeito à captação, ao registro e à definição da informação da atualidade.

No que tange à participação do leitor para com o veículo de comunicação de referência, encontram-se menções a autores que crêem numa clara distinção da interação entre um veículo de comunicação e seu público, em virtude do tipo de regime que governa certos países. Conforme Lonardoni (2004, p. 46):

O autor afirma que nos antigos países denominados 'socialistas', a participação do leitor é valorizada e são reservados espaços de divulgação para toda correspondência que chegue à redação dos jornais e revistas.

Como o contexto sociopolítico do período abordado, no Brasil e em Portugal, está bastante distante de uma visão socialista, entendemos que quando ocorria uma interação do leitor para com a revista, por meio de cartas, estas deviam passar por sério controle, quando não editadas, a fim de que compusessem material das revistas, de maneira apropriada ao que se julgava como adequado, segundo as posturas político-ideológicas mencionadas. Por outro lado, não temos convicção de que essa real interação tenha, de fato, ocorrido em países ditos socialistas. 
Ao buscar a presença de determinados indícios em textos analisados, acreditamos na possibilidade de interpretação de marcas do processo comunicativo, tendo em vista como objeto concreto o uso de algumas palavras em detrimento de outras, na composição de textos.

Souza (1998), em sua dissertação de mestrado, também recorreu aos aspectos lingüísticos e sociais, contudo afirmou que, apesar de ter a intenção de relacionar os universos lingüísticos e sociais, não buscava estabelecer relações de causalidade entre ambos, o que também não é nossa preocupação. Esse tipo de abordagem talvez fosse mais pertinente para um trabalho de cunho mais sociológico.

Proceder a um cuidadoso olhar para a imprensa como material propulsor do pensamento e da reflexão, no que tange às relações sócio-histórico-políticas, por meio de um questionamento do par: mundo / linguagem pode abrir perspectivas para uma ótica transdisciplinar. Dito de outra forma, observar e analisar a utilização de palavras num texto é uma forma de levantar hipóteses concernentes ao pano de fundo social e das relações que permeiam todos envolvidos numa dada comunidade, cada qual exercendo o papel que lhe cabe, segundo o regime de poder instituído.

Assim, há que se levar em conta que as palavras, que, como afirma Bakhtin (2004, p.41), são tomadas a partir de uma multidão de fios ideológicos, os quais servem de trama de todas as relações sociais, em todos os domínios. Continua o autor:

... a palavra será sempre o indicador mais sensível de todas as transformações sociais, mesmo daquelas que apenas despontam que ainda não tomaram forma, que ainda não abriram caminho para sistemas ideológicos estruturados e bem formados.

$\mathrm{Na}$ sequiência do que expusemos como abertura deste trabalho, cumpre-nos esclarecer nossos objetivos. Como um objetivo geral, intencionamos analisar aspectos concernentes à relação do homem com a sociedade, uma relação nem sempre pacífica, amistosa e clara. Interessa-nos delimitar uma pequena fatia dessa interação do homem com o meio pela linguagem.

Para a realização de nosso estudo, temos como objetivos específicos:

- $\quad$ explorar o discurso ideológico que permeia a publicação das revistas analisadas e que pode se mostrar distinto de revista para revista; 
- verificar a abordagem de certos assuntos em diferentes revistas, que, provavelmente, por imposições da censura e/ou postura ideológica, devem ou podem estar orientados de alguma maneira. Isso permitirá verificar como se dá a construção da argumentação, a qual é elaborada, objetivando atingir determinado público-alvo;

- $\quad$ identificar e analisar, por meio de marcas lingüísticas, bem como pela polifonia presente nos textos o ethos das revistas e de seus colaboradores.

Organizamos nosso trabalho em cinco capítulos:

No primeiro capítulo, inicialmente apresentamos dados que situam a década de 60 como uma época de transição, de mudança de paradigmas em todos os setores da sociedade e, portanto, tão marcante. Na seqüência, partimos para uma síntese da ascensão e da queda da Era Salazar. Da mesma forma procedemos para nos remeter à ditadura militar no Brasil, dos conchavos para sua instauração até o seu fim. Mesmo tendo o ano de 68 como período por nós eleito, tanto em Portugal como no Brasil, nesse capítulo, voltamos no tempo, para a década de 20 e seguimos até a década de 80 , para demonstrarmos, cronologicamente, causas e efeitos de um período singular, tanto em Portugal como no Brasil.

No segundo capítulo, abordamos o conceito de ideologia, sob vários aspectos, a partir de dicionários de língua e de um dicionário específico de Sociologia, entretanto, centramo-nos em Althusser, com seus Aparelhos Ideológicos. Em seguida, exploramos o conceito de mídia, em especial da mídia impressa. Com os conceitos traçados, expusemos a relação inquestionável entre ambos.

No terceiro capítulo, buscamos apresentar estudos teóricos que nos propiciaram proceder a análises dos textos do nosso corpus. Nesse capítulo, certificamo-nos da relevância e da possibilidade de articular teorias relativas à Análise do Discurso, aos estudos de Bakhtin, em especial no tocante ao dialogismo e à polifonia, aos Gêneros Textuais, ao ethos.

No quarto capítulo, apresentamos os métodos e os procedimentos adotados para a execução da pesquisa. Além disso, servimo-nos de um histórico relativo a cada uma das revistas trabalhadas, desde sua criação até o encerramento de suas atividades. Esse histórico das revistas foi respaldado no contexto da época de cada país. 
No quinto capítulo, demonstramos, nos textos selecionados das revistas, o modo como procedemos na leitura, na releitura, na decomposição dos mesmos, a fim de chegar a uma análise global do número, num primeiro momento, e da revista, como um todo num segundo momento.

Na conclusão, retomamos nossos objetivos, com o fito de demonstrar o alcance dos mesmos, além de mostrar os resultados encontrados, a partir desse longo percurso. Na seqüência, apresentamos nossas referência bibliográficas e os anexos, em que se encontram os artigos das capas das mencionadas revistas. 


\section{CAPÍTULO 1 - O PANORAMA SOCIOPOLÍTICO DA ERA SALAZAR, EM PORTUGAL, E DA DITADURA MILITAR NO BRASIL}

Se houve na história um movimento em que seus componentes não souberam o que era egoísmo, anulando-se como indivíduos para se encontrar como massa, esse movimento foi o da espetacular, pública e gregária geração de 68

Zuenir Ventura

\subsection{A Emblemática década de 60}

Sob vários aspectos, a década de 60 do século passado mostrou-se muito peculiar no Ocidente, sobretudo no que se refere a uma quase ruptura em cadeia, em relação a padrões, aos paradigmas vigentes até então. Isso se deu tanto no campo político, como no científico e no cultural, não sendo possível nem relevante, para nós, identificar o que influenciou o quê.

É inegável, entretanto, que é um período emblemático e também fonte das mais variadas pesquisas. No entanto, optamos por delimitar alguns anos desse período, nessa parte de nosso estudo, no que se refere especificamente a questões históricas e políticas. Assim nosso olhar ficará mais restrito aos anos de 1964 e início dos anos 70. 1964 é um ano historicamente relevante para o Brasil, em virtude do golpe militar e todas as mudanças e regras por que teve que começar a passar a sociedade, de forma geral. Apesar de nosso objetivo de estudo não adentrar a década de 70 e mesmo a de 80, estas são mencionadas em certos trechos, pelo fato de pontuarem passagens significativas no aspecto sociopolítico de que tratamos.

O período corresponde a uma fase inicial do regime militar brasileiro, mostrandose, pouco a pouco ferrenho e sisudo. Portugal era ainda comandado pela política imposta pelo regime Salazar, já no poder há décadas. 
Em recente matéria da revista Época, o jornalista Amauri Segalla fez uma avaliação do ano de 1968 e seus inesgotáveis reflexos de um ano que, ainda segundo ele, está envolto em uma "aura de magia", (2008,p. 61):

Quarenta anos depois, 68 continua enigmático, estranho e ambíguo como um adolescente em crise existencial (...) ano da livre experimentação de drogas. Das garotas de minissaia. Do sexo sem culpa. Da pílula anticoncepcional. Do psicodelismo. Do movimento feminista. Da defesa dos direitos dos homossexuais. Do assassinato de Martin Luther King. Dos protestos contra a guerra do Vietnã. Da revolta dos estudantes em Paris. Da Primavera de Praga. Da radicalização da luta estudantil e do recrudescimento da ditadura no Brasil. Da tropicália e do cinema marginal brasileiro.

Se a década de 60 apresenta-se como emblemática, o ano de 1968, aos olhos do Ocidente, mostra-se como especialmente simbólico. Courtine recupera o mês de maio do mencionado ano e assevera (2006, p.104):

Maio de 68 marca a emergência repentina de novos valores: um desejo de liberdade individual, de expressão pessoal que refuta as hierarquias, as tutelas e as tradições. Esses valores vão tocar os jovens operários, vão incitá-los a questionar as autoridades familiares, patronais, políticas e sindicais. Maio de 68 é a fase de transição brutal entre dois períodos políticos, a passagem tumultuosa do tempo das "grandes narrativas" ideológicas àquele das expressões individuais, o momento de uma ruptura sentida entre uma idade genealógica baseada no pertencimento, na filiação, na autoridade, e uma idade pessoal, que vai pregar a realização de si, contestando os discursos de transmissão.

Um outro forte ponto de vista sobre o ano, também retirado da revista Época (2008,p.75) é de Zuenir Ventura, que também foi colaborador da revista O Cruzeiro e é o autor do livro "1968: o ano que não terminou”, em que afirma:

Um momento de uma sintonia mágica, misteriosa, que fez ao mesmo tempo as coisas acontecerem em países de regimes diferentes - na Tchecoslováquia, na Polônia, no Japão, na Alemanha, na França e no Brasil. Foi um movimento planetário (...) Acho que foi a primeira manifestação de globalização, antes mesmo de a globalização existir. É um mistério na História, ninguém conseguiu responder até hoje como começou, por que começou naquele ano. 
Levantamos uma possível hipótese de interpretação para o que Ventura afirma, no que se refere ao fato de 1968 ter sido um ano sem fim. Em 68, várias das manifestações ocorridas objetivavam anunciar ou pré-anunciar ações que se faziam necessárias e muitas simplesmente não levaram ao esperado desfecho. Há mesmo quem julgue que de todas as importantes manifestações, a luta das feministas foi a que conseguiu ir mais longe e frutificar. O movimento teve repercussão estrondosa, a ponto ser presente e instituído o lugar da mulher na sociedade, como membro atuante, como profissional, enfim, como cidadã.

Alguns analistas entendem que o período, comparando os acontecimentos do Brasil, os da França e os dos Estados Unidos, os ocorridos aqui apresentavam um aspecto mais político do que nos outros países. Não compactuamos com essa idéia, por não crermos que, de fato, na França os movimentos tenham se dado apenas por exigência dos estudantes para haver quartos mistos nas universidades, como o também exposto na revista Época, mas entendemos o episódio como uma demonstração de descontentamento frente ao governo De Gaulle. O mesmo pode ser dito em relação aos Estados Unidos, em que um movimento tido como "paz e amor" e valorização da natureza, tinha claro teor político, já que uma das sérias reivindicações era o retorno dos soldados americanos que estavam no Vietnã e o fim dessa sangrenta guerra. Fora esse posicionamento avesso à guerra, 1968 foi um ano simbólico para os negros naquele país, na tentativa de alcançar direitos civis, restritos aos brancos, até então. Esse era um movimento pacífico, liderado por Martin Luther King, morto nesse mesmo ano, o que só acelerou o processo dessas conquistas ambicionadas.

É preciso, todavia, não enxergar o momento histórico como igual em diferentes países. Aliás, a repercussão do período apresentou-se distinta de região para região de um mesmo país, em virtude de muitos fatores. A maior ou menor proximidade com as áreas centrais dos países, onde normalmente se iniciavam os movimentos, faz diferença para se analisarem as consequiências de um possível contágio, no que se refere a um engajamento mais politizado.

Toda agitação de uma época é fonte para as mais variadas manifestações artísticas e, no Brasil, 1968 contou com marcantes presenças nesse campo, tanto no chamado cinema novo, como na música com a Tropicália, encabeçada por Caetano Veloso, Nara Leão, Gilberto Gil e também no teatro, com produções da chamada contracultura, com José Celso 
Martinez, encenando a peça marginal "Roda Viva", de Chico Buarque. São muitas as opiniões de que graças ao aumento da censura, em especial a partir de 1968, os festivais de música, aqui, representavam quase que uma forma de resistência, quando inúmeros jovens conseguiam estar juntos, em grupos. Orlandi (1997) afirma mesmo ter sido um momento em que as pessoas, como não podiam se manifestar politicamente, aprenderam a se reunir, a juntar a multidão em encontros musicais. O cantar de mãos dadas, até mesmo o hino nacional e o empunhar a bandeira assumiam o valor bem mais elevado do que o patriotismo apregoado pelos militares.

Se a censura, paradoxalmente, impulsionou uma arte tida como subversiva, muitos crêem também que para combater o autoritarismo a mídia também se viu impulsionada pelas reações de oposição à ditadura militar. É nesse período que surgiu, como forma de expressão cultural, a imprensa alternativa. Os jornais alternativos defendiam a liberdade de expressão e foi essa imprensa a tida como portadora de um projeto político no Brasil.

Num âmbito mais global, o mundo assistia a efeitos da Segunda Grande Guerra, que originou o período denominado "Guerra Fria". Diante desse quadro, a população mundial, de forma geral, via-se dividida entre duas potências, os Estados Unidos e a União Soviética. Essa divisão foi uma facilitadora para a instauração de governos totalitários, com o intuito da chamada preservação da ordem.

Paulatinamente após a guerra, os socialistas começaram a perder a combatividade. Muitos de seus adeptos, segundo alguns historiadores, por medo ao Comunismo e/ou descrença no regime, graças ao que se soube sobre as barbáries de Stalin, tenderam, de forma dominante, a fazer com que o Socialismo se aproximasse do centro. Isso contribuiu para um posicionamento político preponderantemente mais autoritário e até conservador.

Descrever o cenário sociopolítico de um país que esteve subordinado à ditadura apresenta, em virtude do "pano-de-fundo" de leis e obrigações inquestionáveis, não muito distinto de uma nação para outra. Há particularidades, contudo entendemos que as estratégias de manutenção de um governo totalitário não se mostram muito inovadoras, nem tão pouco sutis, tudo em nome dos interesses que envolvem um regime dessa natureza. Volta e meia, então, temos a impressão de que atitudes governamentais ora podiam ser atribuídas à ditadura militar do Brasil, ora à ditadura Salazar em Portugal, tendo em conta 
os métodos, as ações de quem estava a serviço do governo, assim como as conseqüências vividas pela população.

Essas conseqüências, entretanto, também apresentam uma gradação não só pontuada pela maior ou menor rigidez do período de determinada ditadura, como também levando em conta o reflexo das ações em uma cidade grande ou uma aldeia, uma pessoa letrada ou um camponês, um indivíduo mais idoso, aposentado e um jovem universitário, por exemplo.

Não nos parece adequado nem relevante partirmos de um julgamento para verificar se uma ou outra ditadura foi mais nefasta, mais ou menos severa. Passaremos a uma breve retomada dos aspectos políticos de Portugal em seus quarenta e oito anos da era Salazar e, no Brasil, da ditadura que também atravessou décadas.

\subsection{A Era Salazar}

Em Portugal, o salazarismo teve seu início em 28 de Maio de 1926. Como em alguns países europeus, a ascensão de Salazar, uma imposição ao país, por meio de dois generais - Gomes da Costa e Mendes Cabeçadas - inseriu-se numa conjuntura de ascensão de governos autoritários que se apresentava em conformidade com ideais nazi-fascistas e franquistas.

Salazar tomou posse como ministro das finanças, porém, aos poucos, tornou-se, aos olhos de muitos, como "um senhor absoluto", em especial após 1932, ao assumir o cargo de Presidente do Conselho de Ministros. A essa longa época salazarista denominou-se "Estado Novo".

Os partidos políticos foram proibidos e o poder ficou restrito e concentrado na figura de Salazar. Só poderia concorrer à eleição para presidente da república um candidato indicado por Salazar. O regime foi ficando mais severo e, como tantos outros, contava com um órgão de vigia e controle, a PIDE - Polícia Internacional de Defesa do Estado. Para Magalhães e Alçada (2004), era mesmo uma rede de espionagem interna. A PIDE ainda mantinha informantes civis, contratados para avisar sobre qualquer pessoa ou fato que se mostrasse contrário ao governo. 
Portugal era um país que tinha sua população muito mais concentrada nas aldeias do que nas cidades. De acordo com Verdasca $(2006)^{* 2}$, cerca de apenas trinta a trinta e cinco por cento da população vivia nas cidades. Apesar dessa concentração, poucas eram as aldeias que contavam com escolas secundárias e era comum, até os anos cinqüenta e sessenta, grande parte das pessoas ter muito pouca educação formal. Esses dados são relevantes, se levarmos em conta que um governo, ditador ou não, poderia nem sequer ser questionado por pessoas com pequena participação política, em virtude da parca escolaridade e da escassez de informação. Assim sendo, não podemos deixar de colocar em causa que a ditadura Salazar, bem como outra qualquer, deve ser vista de maneira distinta, pelos diversos setores da sociedade. $\mathrm{O}$ fato é que, em uma ditadura, geralmente quem se beneficia é uma minoria.

Quanto à estrutura política e administrativa, havia as freguesias e quem as presidia eram indivíduos nomeados e não eleitos pelo voto popular. Apesar de não existirem eleições para esse tipo de cargo, comum era que as pessoas dessem mostras de aprovação dos mandatos desses administradores, caso se vissem, de alguma maneira, sanadas em suas necessidades pessoais, caso recebessem, direta ou indiretamente, tais benefícios.

Nos limites urbanos, o Estado Novo assumia um papel mais centralizador, embora o governo Salazar mantivesse eleições para a Assembléia Nacional, onde os deputados discutiam e aprovavam leis, que não representavam a vontade do povo, mas apenas seguiam interesses do governo.

Para alguns, havia um forte "jogo de cena" de Salazar, em virtude de sua preocupação com a imagem fora do país. A respeito disso, afirmam ainda Magalhães e Alçada (2004, p. 19):

... para criar uma certa ilusão dentro do país e para dar uma imagem de abertura ao estrangeiro, na altura das eleições, e só na altura das eleições, o governo fingia tolerar alguma oposição. Não aceitava a existência de partidos políticos, mas admitia que surgissem candidatos a Presidência da República. Mas se por acaso os opositores vencessem, os resultados eram alterados, porque só as pessoas fiéis a Salazar é que faziam a contagem dos votos.

\footnotetext{
${ }^{2} \mathrm{O}$ autor e estudioso português José Verdasca concedeu-nos uma entrevista em primeiro de dezembro de 2006.
} 
Contudo, de acordo com Teles (2000), a pacatez lusitana viu-se abalada com o desenvolvimento da campanha relativa à candidatura à presidência da república, em torno do general Humberto Delgado, em 1958. Indubitavelmente, esse quadro político-social foi material importante para manifestações culturais, que assim como a imprensa, sofriam severa censura. Não raro jornais saiam com textos em que facilmente se percebia a exclusão de períodos ou trechos; obra da censura em eterna vigília.

Por causa dos grandes contrastes sociais e da pouca informação que chegava a muitas aldeias de todas as regiões, um número elevado de pessoas não se dava conta da real situação e do que, de fato, representava o poder de Salazar e suas medidas inquestionáveis. Sem dúvida, o analfabetismo e a fraca e/ou pouca instrução eram fundamentais para esse estado de coisas.

Levando-se em conta outros países da Europa, Portugal ficava, dia-a-dia, mais para trás, estagnado nos seus próprios limites. Entretanto, tal isolamento atingia também pessoas mais bem formadas, tendo em vista a proibição da entrada de livros, revistas, além da proibição da censura a determinadas publicações locais, do que o governo entendia como um tipo de atentado à sua manutenção no poder.

Pouco a pouco, o descontentamento foi atingindo cada vez mais pessoas, uns por poderem viajar e ter acesso a mais informação, outras por sofrer as conseqüências de um governo ditatorial que parcamente provia seu povo. Entretanto, nas aldeias, as poucas pessoas que tinham uma visão contrária à situação e tentaram se organizar para algum tipo de resistência foram rapidamente reprimidas pela PIDE. Muitas das aldeias eram compostas por mil e quinhentas, duas mil pessoas, das quais grande número vivia com dificuldade. Essa situação facilitava a ação da PIDE, no sentido de comprar informações e, assim, agir de forma imediata e direta nas poucas pessoas que tentaram se opor.

Não era incomum que essas pessoas fossem conduzidas pela PIDE à prisão política de Caxias, local em que eram detidos os oponentes a Salazar. O local era bastante temido, pois, segundo informações, existia uma sala destinada à prática de tortura, que havia sido preparada com auxílio da CIA. Contudo, muitos dos que lá chegavam, após algum tempo, por se verificar que não representavam, de fato, uma ameaça, simplesmente eram liberados.

A situação começou a tomar um outro sentido, no momento que outros países europeus, paulatinamente, viram como inadiável a desocupação dos territórios ocupados, 
muitos no continente africano. $\mathrm{O}$ anticolonialismo passou a ser uma tendência natural do pós-guerra, juntamente com a emergência do Terceiro Mundo. O fenômeno anticolonialista se manifestou de forma violenta e acabou por introduzir significativas alterações na estrutura política-jurídica do Ultramar.

Portugal se viu mais pressionado, a partir de sua entrada, em 1955, como membro das Nações Unidas. Um ano mais tarde, as Nações Unidas, por meio do chamado artigo 73, questionaram se Portugal mantinha colônias, no Além-Mar. De acordo com esse artigo, esses territórios deveriam ter seus interesses reconhecidos como prioritários e ter assegurado o desenvolvimento político, econômico, social e educativo dos respectivos povos e promover a implantação de governo próprio. Todavia Portugal negou manter colônias e afirmou que os territórios em questão constituíam-se em províncias que integravam uma nação pluricontinental. Em outras palavras, Portugal não admitiu administrar territórios não-autônomos e ainda afirmou que os mesmos não tinham vocação para independência.

O posicionamento de Portugal gerou perplexidade não só para líderes afro-asiáticos, como repercutiu muito mal em outros países da Europa. As Nações Unidas voltaram a pressionar e pedir que o governo Salazar prestasse contas de sua administração nos territórios em voga. Portugal recusou-se a fornecer essas informações e a crise só se agravou, em especial a partir de 1961, em virtude de o país ser rotulado como colonialista. De outro lado, para "salvaguardar" os direitos dos então ainda colonizados, uma eleição nos Estados Unidos pareceu trazer a resolução para tais impasses.

Conforme Nogueira (2000, p. 256):

É a eleição de John Kennedy, e a sua política da "Nova fronteira" que, conduzido pelos intelectuais de Harwad, atribui aos Estados Unidos uma nova missão global de natureza messiânica. Esta abrange a África, e o governo Washington quer apresentar-se perante o continente no mesmo terreno e com a mesma imagem que se tem apresentado a União Soviética. Ambos os países são campeões da liberdade dos povos, paladinos do anticolonialismo, arautos dos direitos humanos, defensores da paz internacional.

Foi nesse mesmo ano de 1961 que se iniciaram em Angola, seguidamente de Guiné e Moçambique, levantes armados contra a colonização portuguesa, de séculos de 
exploração. Nesse contexto, os órgãos de imprensa de muitos países, inclusive do Brasil, após a eleição de Jânio Quadros, passaram a ter uma atitude hostil em relação a Portugal. Outro forte baque sofreu o Estado Novo com a luta e a independência de Goa. Mesmo com medidas para tentar abrandar os ânimos dos afro-asiáticos, como, por exemplo, o estabelecimento daquilo que o governo chamou de completa igualdade de direitos políticos entre os portugueses da África e da metrópole, ecos de movimentos libertadores começaram a eclodir, com cada vez mais frequiência.

Em 1962 foi anunciada a criação de um partido africano para a independência da Guiné e de Cabo Verde. No ano de 1964, surgiu a OUA (Organização de Unidade Africana), constituída em maio de 1963. Por outro lado, a partir de 1962 as críticas da ONU a Portugal tornaram-se sistemáticas e constantes.

Para descontentamento de todos os lados, das Nações Unidas, de países de outros continentes, bem como das próprias famílias portuguesas, a crise se agravou ainda mais, e soldados continuavam a ser enviados à África para combates e mais combates, numa guerra que já não fazia mais sentido, mas que seguia fazendo vítimas e desestruturando famílias.

Embora não se possa afirmar que uma ditadura seja feita por um único homem, Salazar era centralizador ao extremo, a ponto de, segundo algumas fontes, demitir ministros, ele próprio, sem prévio aviso, por telefone. Isso apenas para elucidar a forma como conduzia o país, além da insistência na manutenção da interminável ocupação de tropas portuguesas na África.

Ainda conforme nos relatou Verdasca (2006), em entrevista, a vida na África era insalubre na maioria dos casos, onde muitos dos soldados, além de pouco preparados, contavam com sucatas como equipamentos bélicos e se sentiam sob forte ameaça, uma vez que eram minoria absoluta nos países africanos.

Em 1968, Salazar sofreu um acidente e se afastou definitivamente do poder, que já estava em franca decadência. Foi sucedido por Marcello Caetano, no mesmo ano. Apesar de este manter a linha salazarista, notou-se uma pequena abertura, sem, no entanto, apresentar profundas alterações. No ano de 1969, houve eleições para a Assembléia Nacional, embora tenham se apresentado legendas de oposição ao governo, esta não conseguiu eleger nenhum deputado. Salazar veio a falecer em 1970. 
Dentro do panorama da guerrilha, a situação conservou-se sem alteração significativa entre os anos de 1964/1965 e 1970/1971. Alguns estudos apontam que dos dez milhões de habitantes de Portugal, cerca de um milhão foi enviado ao continente africano, nos anos de guerra. Muitos dos quais ou não voltaram ou voltaram com terríveis seqüelas. Esses anos corresponderam ao período mais intenso da guerra no Ultramar. O quadro se modificou a partir dos primeiros anos da década de 70, muito pelo fato de aumentar a dificuldade no recrutamento de soldados para combater na África e da crescente reprovação internacional, no que se refere ao colonialismo. Somado a esse quadro de problema com o contingente a ser enviado para a África, Portugal estava cada vez mais comprometendo capital vultoso para manter os homens no Ultramar e para a compra de materiais bélicos.

Enfim, a situação já não contentava a grande maioria, então conspirações passaram a ter maior repercussão e o caminho para a revolução parecia estar melhor traçado e definido. Magalhães e Alçada resumem o período (2004, p. 39):

A iniciativa de preparar a revolução partiu de um grupo de oficiais das Forças Armadas (...) As reuniões clandestinas tinham começado em 1973, na intenção de derrubar a ditadura, implantar a democracia e acabar com a guerra colonial. (...) Uma primeira tentativa, a 16 de março de 1974, falhou. Mas os conspiradores (...) mantiveram-se firmes na decisão e fizeram um plano muito completo (...) contactaram unidades do Exército e conseguiram que 27 aderissem (...) unidades da Marinha e da Força aérea prometeram manterem-se neutras.(...) os conspiradores resolveram que o dia " $\mathrm{D}$ " seria a 25 de abril. (...) à meia noite e vinte e cinco minutos, já madrugada de 25 de Abril, a rádio Renascença transmitiu "Grândola, Vila Morena", uma das poucas canções de Zeca Afonso que a censura não tinha proibido. E isso significava "Chegou a hora. Avancem!"!

O compositor e cantor, de acordo com o jornalista Teles (2000), transformou-se, mesmo a sua revelia, na representação viva do 25 de abril. Um nome muito importante na chamada música de intervenção no período e que, por conta disso, sofreu com a censura e chegou mesmo a ser preso.

Vale a pena relembrar que, na música, o fado, música tradicional portuguesa, representava a canção nacional, de alguma maneira, em consonância com o regime salazarista. É em Coimbra que um movimento ligado à música começou a desenhar-se como distante do fado tradicional. José Afonso e Adriano Correia de Oliveira eram os 
grandes impulsionadores do movimento que atraiu muitos jovens. A escolha como sinal de avanço para a revolução de abril, da música Grandôla, Vila Morena, não se deu aleatoriamente. Foi a única música de Zeca Afonso a passar, na íntegra, pelas malhas da censura. Ainda em Teles (2000, p. 156):

... foi o grande coro colectivo, a culminar (...) a entoar os versos de Grandôla, Vila Morena (...) E é o seu grande impacto na noite de 29 de março que irá determinar a sua escolha para senha do movimento das Forças Armadas, na noite de 24 para 25 de abril.

O fato é que poucas horas depois do sinal, Lisboa encontrava-se sitiada. Houve alguma tentativa de resistência, entretanto os ministros renderam-se ao fim da tarde, sobre forte emoção popular. A única organização que não se rendeu foi a PIDE. Alguns agentes, fechados na sede, atiraram contra a multidão que se encontrava em frente ao edifício. Houve quatro mortes. Mesmo com essa tentativa cruel e covarde de resistência, nada puderam fazer além de se entregar, pouco tempo depois.

Como o previsto num final de ditadura, presos políticos foram soltos e Portugal finalmente passava a fazer parte dos países livres e democráticos. Um dos movimentos políticos mais importantes do período, a "Revolução dos Cravos", em 1974, só ocorreu pelo gradativo enfraquecimento do poder de Salazar e com a emancipação das colônias africanas.

\subsection{A Ditadura Militar do Brasil}

A década de 60 , no Brasil, foi crucial e extremamente marcante por inúmeros acontecimentos. Já em 1960 a inauguração de Brasília, construída no regime JK, obra marco de um governo populista, é simbólica do momento em que se começou a abrir o país para o capital externo.

Juscelino Kubitschek, no final de 1961, passou a faixa presidencial a Jânio Quadros. Após sua posse, o país presenciou um número assustador de fatos políticos que envolveram toda a sociedade e, apenas sete meses depois de empossado como presidente, Jânio renunciou. 
Nos bastidores da crise, os militares já se articulavam e achavam por bem que o vice de Jânio, João Goulart, o Jango, por sua suposta ligação com comunistas, não assumisse o poder. Contudo, os militares sofreram forte reação e aceitaram como solução que Jango exercesse o poder, mas sob o regime parlamentarista. Jango não foi mantido no poder por muito tempo e sobre esse fato, Arruda e Piletti (1996, p. 321) explicam:

Jango tomou medidas que, em parte, o levariam a perder o poder: * convocou plebiscito em que, por ampla maioria, em 06 de janeiro de 1963, recuperou os poderes de presidente previstos na Constituição de 1946;

* em dezembro de 1963, estabeleceu o monopólio estatal sobre importação de petróleo e derivados;

* em janeiro de 1964, regulamentou a remessa de lucros ao exterior;

* em 13 de março de 1964, durante um comício no Rio de Janeiro, assinou decretos que nacionalizavam as refinarias de petróleo e desapropriou mais de cem hectares, numa faixa de $10 \mathrm{~km}$ ao longo de rodovias e ferrovias federais.

Eram reformas de base; elas incluíam o voto do analfabeto e a reforma universitária, que assegurava a liberdade de ensino.

Nesse período, cresceu maciçamente a participação popular, que pressionava o governo Goulart por transformações no país. A UNE, os jovens católicos, os comunistas lutavam, cada um a seu modo, em seu próprio espaço de atuação, pelas chamadas reformas de base. Os comunistas, apesar de desenvolverem intenso trabalho de organização e mobilização popular, tinham seu partido na ilegalidade. Somando-se a esse "cordão" de pessoas engajadas, houve crescente número de sindicados, os rurais, por exemplo, multiplicaram-se.

Todas essas mobilizações provocaram reações, sobretudo nos setores conservadores da sociedade, surgindo, então, grupos que denunciavam a "subversão" no Brasil. Com todo esse panorama, Jango começou a perder o apoio popular e os militares continuavam sua conspiração. As dificuldades econômicas também ajudaram a derrubar Jango; a inflação de 1963 foi de 73\%. O começo de 1964 se deu de forma muito tumultuada. Então, conforme os dados apresentados por Arruda e Pilettti (1996, p.323):

Em 30 de março, tropas mineiras começaram a deslocar-se rumo ao Rio. Na noite de 31, o governador de Minas, Magalhães Pinto, lançou manifesto rompendo com Jango e acusando-o de tentar 
realizar reformas sacrificando a normalidade constitucional e de acolher planos subversivos que pretendiam tiranizar o povo. Outros comandantes e os governadores de São Paulo, (...) e da então Guanabara (...), aderiram aos conspiradores.

Em primeiro de abril, Jango viajou para o Rio Grande do Sul, onde Leonel Brizola, agora deputado federal, pretendia organizar a resistência junto com organizações populares. À noite, o presidente do senado, Auro de Moura Andrade, declarou vaga a presidência, contra a Constituição, pois Jango se encontrava em território nacional, e deu posse ao presidente da Câmara, Ranieri Mazzili. Jango estava deposto.

Antes mesmo da deposição de Jango, eram fortes as negociações para um eminente sucessor. Estava praticamente acordado que este seria um militar. De acordo com Fausto (2000), o movimento de 31 de março de 1964 se deu, aparentemente, com o fito de livrar o país da corrupção e do comunismo, além de ser proclamado como um instrumento para o retorno da democracia. Sabe-se, no entanto, que o regime começou a agir em várias instituições do país, por meio dos atos institucionais, os AI, justificados como decorrência do exercício do poder constituído.

O primeiro AI foi baixado em início de abril de 1964, tendo por conteúdo a manutenção da Constituição de 1946, entretanto com diversas modificações, além de os militares mostrarem ter poder para interceder no funcionamento do congresso, o que, aliás, foi uma das características de todo o regime militar. Muitas das medidas desse primeiro ato institucional visavam ao aumento do poder executivo, na mesma proporção em que diminuía o poder do Congresso e da Câmara, além de ter criado condições para a instauração, também, dos inquéritos policiais-militares.

Mazzili antecedeu o chamado poder instituído, foi presidente interino por, talvez, menos tempo que pensava ocupar o cargo, mas que nada podia fazer contra esse estado de coisas, a não ser se conformar e aceitar a precipitação para as eleições indiretas.

Diante dos fatos, UDN e PSD entenderam como viável o nome de Castelo Branco, um general tido como de linha branda. A UDN acreditava na importância de um militar que, de preferência, não tivesse participado de ações militares internas; então tudo indicava que tinham chegado mesmo a um nome adequado para o cargo. Para alguns, o militar pode ter tido a idéia de que ocuparia o cargo para reestabelecer a ordem de que tanto precisava o país, não tendo muito a noção do precedente que estaria abrindo. Castello Branco (1977, p.1) explicou a situação, de acordo com seu ponto de vista: 
O governo Castelo Branco foi um movimento que, tendo pretendido ser uma intervenção saneadora para assegurar o funcionamento dos poderes da república, terminou por implantar um longo regime militar, orientado por um sistema ou um aparelho, que preservou das instituições civis apenas um arcabouço sem alma.

Nesse panorama de tanta instabilidade, Juscelino Kubitschek era uma figura que claramente simbolizava uma perturbação política, já que ainda contava com grande prestígio, em variados setores da sociedade. O ex-presidente, de forma estratégica, apesar de se dizer favorável a um militar no poder, insistia nesse quadro, como sendo provisório e já iniciara certa sondagem, para uma possível aliança com o PTB, visando à eleição presidencial de 1965. Havia quem apostasse que o clima instaurado por essa sondagem fizesse parte do plano de JK, a fim de conseguir maior visibilidade, uma eventual aliança dos trabalhistas com o candidato do PSD à próxima eleição popular para presidente.

Castelo Branco sagrou-se presidente, mas, embora houvesse certa ansiedade para que o poder fosse logo transferido do chamado comando revolucionário para o chefe do governo escolhido internamente e que, dessa forma, findasse o conturbado período do exército nas ruas, este decidiu não tomar posse de imediato. O presidente tinha uma árdua tarefa: enfrentar a catastrófica situação financeira deixada pelo governo Goulart. Nasceu, assim, o PAEG, Programa de Ação Econômico do Governo, com o propósito de cortar imediatamente os gastos públicos.

Na sequiência de sua posse, muitos políticos se viram com seus direitos cassados, como foi o caso, por exemplo, de Juscelino Kubischek, Jânio Quadros e Leonel Brizola e Lacerda se candidatou, oficialmente, para concorrer às eleições presidenciáveis de 1965, que não viriam a ocorrer.

Em virtude do que estava previsto no AI-1, somando-se à suspensão das imunidades parlamentares, das cassações, desencadearam-se as primeiras perseguições aos oponentes ao regime militar, com prisões e torturas. Contudo, o regime ainda não era totalmente fechado, sendo possível, por exemplo, a utilização do recurso do Habeas Corpus. Nesse período inicial do regime, a imprensa apresentava-se como relativamente livre. Aliás, segundo Fausto (2000), foi graças a uma denúncia do jornal do Rio de Janeiro, "Correio da 
Manhã”, que o presidente Castelo Branco veio a saber de denúncias de tortura e, assim, autorizou uma investigação sobre o caso, entretanto esta acabou por ser arquivada.

Ainda em 1964, criou-se o SNI, Sistema Nacional de Informação, uma maneira de controlar os cidadãos, com o objetivo de não abrir precedentes para algum tipo de ato subversivo. Para Fausto (2000), na prática, transformou-se em um centro de poder quase tão importante quanto o Executivo, que agia por conta própria na "luta contra o inimigo interno".

As eleições diretas estaduais, de 1965, deixaram os militares da linha dura em estado de alerta, já que a oposição conseguiu vencer em importantes estados. Esse grupo do exército enxergou a situação como de responsabilidade de um governo complacente.

Como o presidente passou a sofrer mais pressões, aprovou outros AIs, reforçando ainda mais os poderes do executivo, extinguiu os partidos políticos, possibilitando a existência apenas de dois, a ARENA e o MDB, aquele a serviço do governo. Essas entre outras medidas viabilizaram ao regime cada vez mais seu enrijecimento. Essa linha tida como mais branda do exército não conseguiu fazer um sucessor. $\mathrm{O}$ mandato de Castelo Branco imprimiu ainda mais algumas mudanças nas instituições do país, finalizando por conseguir aprovar nova constituição, no início de 1967.

A eleição para presidente ocorreu em 1966, e quem assumiu a presidência, em março de 1967, foi um militar, já tido como parte do grupo linha dura, o general Costa e Silva, que se por um lado se distanciava da maneira intelectualizada de conduzir o cargo, próprio do general Castelo Branco, por outro parecia mais afinada com o grupo mais severo do regime. Não se pode negar, no entanto, que havia também certo alvoroço positivo, pairando na sociedade, ao menos é o que afirma Ventura (1988, p. 23)

Com algum otimismo, encontravam-se boas razões para se esperar um feliz 1968. A efervescência criativa de 67 não era por certo um mau sinal. "Terra em Transe", "Quarup", o Tropicalismo, "Alegria, alegria", "O Rei da Vela", talvez fossem só o começo. Além do mais, o movimento estudantil, cujas entidades haviam sido postas fora da lei pelo golpe de 64, vinha se reorganizando e mobilizando a massa de secundaristas e universitários.

No entanto, a repressão política se intensificou no país, a partir desse segundo presidente militar, apesar de publicamente o discurso geral ser de democracia ou de 
restabelecimento desta, além da retomada da ordem da nação. É dessa época o crescimento de militares em cargos importantes e também é desse período o início de uma reprovação mais clara de membros da Igreja, no tocante ao governo, de forma geral.

Lacerda decidiu se aproximar de antigos inimigos políticos, como Juscelino Kubitschek e Jango, a fim de formar uma ampla e forte oposição ao regime. Para tanto, necessitaram se reunir fora do país, mas houve eco dessa possibilidade de redemocratização do país.

Assim, em 1968 as mobilizações passaram a ser mais constantes e ganharam variados setores da sociedade, o que foi, de fato, também um reflexo do que vinha ocorrendo, de forma mais generalizada nos países do Ocidente, em especial na Europa e nos Estados Unidos, onde as manifestações contra a guerra do Vietnã se fizeram ouvir.

Outras questões estavam em voga, nas reivindicações dos jovens, como relacionadas à educação, à liberdade sexual, bem como um papel mais ativo da mulher na sociedade. Todas esses aspectos, da mesma forma, inflamaram muitas pessoas no Brasil. Muito desse eco pôde ser verificado nas manifestações culturais. Um especial espaço foi verificado pela música de protesto.

1968 eclodiu como um ano de necessárias e imprescindíveis mudanças, o que também o foi no Brasil, onde as mobilizações ocorreram por variados motivos, mas que confluíam para um desejo maior: o fim de um governo de ditadura militar. Ainda do ponto de vista de Fausto (2000) se houve um motivo catalisador para as inúmeras manifestações que passaram a ocorrer, sem dúvida a morte de um estudante secundarista, no Rio de Janeiro, pelas mãos da polícia, contou enormemente com isso. Com união da Igreja e da classe média carioca, aconteceu a famosa "Passeata dos 100 mil", em junho de 1968. De maneira quase concomitante, ocorreram, apesar de proibidas, duas greves operárias, uma em Contagem, Minas Gerais, um movimento de cunho mais espontâneo e, outra, em Osasco, de maneira mais orquestrada pela influência da esquerda, em que houve o envolvimento de alguns estudantes.

Nesse panorama conflituoso, a esquerda dividia-se na ala favorável e na contrária a ações armadas. O PCB se opunha e, portanto, sofreu com o rompimento de um ativista importante: Carlos Marighella. Este, juntamente com outros dissidentes, criou a ALN (Aliança para Libertação Nacional) e assim se iniciaram as primeiras ações em 1968, que 
foram desde atentados a bombas, como no consulado americano em São Paulo, a assaltos a trens pagadores e bancos.

A linha mais autoritária dos militares estava em alerta e precisava apenas de um pretexto para agir. Foi então, frente a um discurso de um deputado carioca, que propôs um boicote à parada militar de setembro, ato de pouca relevância e visibilidade para a sociedade civil, mas visto como o espaço propício para atuação militar. $\mathrm{O}$ alto comando militar não levou em conta a imunidade parlamentar, que tinha voltado a existir, num dos AIs assinados ainda por Castelo Branco, e impôs um processo criminal contra o deputado. Para dar prosseguimento ao processo, necessitava-se de uma licença do congresso, que não cedeu às pressões dos militares e como sanção, menos de vinte e quatro horas depois, viuse fechado, pela instauração do AI-5, de dezembro de 1968, assinado por Costa e Silva.

Fausto (2000, p. 480) entende o e AI-5 da seguinte maneira:

... instrumento de revolução dentro da revolução; não tinha prazo de vigência como os outros e durou até início de 1979. O presidente da república voltou a ter poderes de fechar provisoriamente o congresso e ainda intervir nos municípios e estados, voltou a poder cassar mandatos e direitos políticos e proibiu-se a utilização do Habeas Corpus. Estabeleceu-se na prática a censura aos meios de comunicação, a tortura passou a fazer parte integrante dos métodos do governo.

A ditadura brutal e impiedosa estava instituída. Em 1969, Costa e Silva sofreu um derrame, mas os ministros não aceitaram o vice em seu lugar, uma vez que este era civil, além de ter se colocado oposto ao AI-5. Assumiram, entretanto, o poder os ministros da aeronáutica, da marinha e do exército.

Se é correto afirmar que o pulso firme do governo militar ficou muito mais rígido e cruel, é verdade também que as ações dos chamados subversivos se mostraram mais contundentes. Haja vista o êxito no seqüestro do embaixador americano, que possibilitou a troca deste por quinze presos políticos. Após liberados, viram-se banidos do território nacional. $\mathrm{Na}$ tentativa de controlar firmemente essas ações, o regime criou os DOI-CODI, em vários estados. Eram os destacamentos de operações e informações e centro de operações de defesa interna, o maior centro de tortura do regime militar. 
Em outubro de 1969 foi marcada a eleição para presidente. Este assumiria o cargo em trinta de outubro e teria findado seu mandato em março de 1974. Assumiu o comando da nação o general Emílio Garrastazu Médici. Era um nome já ativo nos governos anteriores, tinha sido chefe do SNI no governo de Costa e Silva. Sem dúvida o período mais nebuloso, violento e voraz de todos os mais de vinte anos de ditadura.

Já como presidente, Médici comandou a seleção dos então futuros governadores dos estados. Seguiu-se um período bastante sinistro, de perseguição e sumiço de pessoas tidas como iminentes ameaças à ordem da nação. A notícia de tortura de presos atingiu a imprensa internacional, o que foi sumariamente desmentido pelo governo.

Foi sob o comando de Médici que os grupos armados começaram, de forma rápida a decair e praticamente desaparecerem, muito devido à eficaz repressão mais forte instaurada. Marighella morreu em novembro de 1969, fruto de uma operação policial; Lamarca seria morto em 1971, na Bahia, ainda no governo Médici. Um outro grupo, ligado à ação armada e que se encontrava em relativo sigilo, no Pará, perto do rio Araguaia, foi descoberto em 1972. Após anos de resistência e conflitos e de não terem cedido facilmente à tortura, em 1975 os guerrilheiros do Araguaia, em sua maioria foram exterminados, de uma forma ou de outra.

Vários desses acontecimentos não chegaram ao conhecimento do grande público, muito por causa da censura nos órgãos de imprensa. Como a divulgação desses assuntos era proibida, o mais comum eram apenas boatos acerca dessas questões.

Apesar de atos escusos, a sociedade conhecia bem a propaganda favorável ao governo Médici, feita em especial pela ARENA. Muito de o governo ter boa avaliação e/ou aceitação se dava por causa dos bons resultados na área econômica. Em virtude desses resultados, por exemplo, adquirir um televisor ficou cada vez mais facilitado para um grande número de pessoas. O que se chamou de "milagre brasileiro", período compreendido entre 1969 e 1973, não passou, realmente, de um engodo para a sociedade, já que os números da economia eram positivos, muito por causa de empréstimos contraídos com o FMI e capitais estrangeiros de outras instituições, que fez com que o país se visse com uma dívida externa imensa.

Aliado a esses reais dados, aumentou a dependência do capital estrangeiro, que a partir da crise do petróleo começou a minguar e a população passou a sentir os efeitos do 
falso milagre econômico, uma vez que se viu abandonada, no que se referia aos programas sociais, com baixos níveis escolares e de saúde, isso somado a uma grande falta de habitação.

Ao final do mandato, Médici também não conseguiu fazer um sucessor e quem subiu para o comando do Brasil foi o general Ernesto Geisel, que compactuava com muitas das idéias do grupo castelista. Alguns estudiosos acreditam mesmo que foi um colaborador de Castelo Branco e conseguiu, de alguma maneira, conter à distância a ala linha dura do exército, naquela altura de início de regime militar. No entanto, não seria adequado entender o general como "mensageiro" de um iminente início de abertura. O período de seu mandato, de 1974 a 1978, foi marcado por avanços e recuos, no tocante a um possível afrouxamento do regime, no sentido de uma abertura, que se deu de forma lenta, gradual e insegura.

O desgaste do governo se dava em grandes proporções e por diferentes áreas e motivos, um deles foi o constante confronto com a Igreja, que se mostrava claramente contrária à tortura.

Em 1975 houve um outro baque não só para a sociedade, mas para a imagem do governo, a morte do jornalista da TV Cultura, Vladimir Herzog. Ele havia sido intimado a comparecer ao DOI-CODI para prestar esclarecimentos, sob uma suposta ligação com o PCB. O jornalista apresentou-se e, ao que tudo indica, como não sobreviveu à tortura, veio a falecer. O governo não tinha como esconder um fato dessa dimensão e nem podia se mostrar comprometido, então a versão apresentada sobre a morte de Herzog é que teria sido um suicídio.

Diante de tanta indignação da sociedade, de uma forma geral, Geisel resolveu agir e cessaram as torturas nos DOI-CODI. Por outro lado, em 1977, intentando a aprovação de várias medidas e não tendo o apoio de que necessitava, viu como alternativa colocar o congresso em recesso e, assim, baixou alguns decretos-lei, entre eles o aumento de cinco para seis anos no mandato do presidente.

Como já dito antes, o momento era de uma certa inconstância, se falar em paradoxo pode parecer exagero. Em 1978, o governo iniciou um certo diálogo com líderes do MDB, assim como com representantes da CNBB, a fim de que encontrassem um caminho para a restauração da liberdade pública. Foi desse ano, ainda, a aprovação de uma emenda, que 
revogava o AI-5, e, assim, o poder executivo já não teria poder para fechar o congresso, nem cassar mandatos ou poderes políticos de cidadãos, além de o recurso do Habeas Corpus ter sido restaurado.

O fim de mandato do presidente Geisel foi bastante conturbado, começaram a existir pressões dos empresários, que já não viam com bons olhos a grande intervenção do Estado; o movimento sindical tornou-se mais estruturado e atuante, além do surgimento de um movimento sindical, ligado à Igreja. Em 1979, um grande número de trabalhadores entraram em greve, em todo o país. Mais uma vez um militar foi acusado de um mandato complacente com ações que poderiam comprometer ainda mais o controle da nação, já tão fragilizado.

No mês de março de 1979, tomou posse o último presidente militar, o general João Baptista Figueiredo. O nome de Figueiredo era tido pelo alto comando como representativo para, enfim, comandar e prosseguir com o processo de abertura. No poder, não coibiu a luta pela anistia. Esta foi, aos poucos, ampliada, assim como a grave crise econômica. Mais uma vez o governo se viu com a necessidade de cortar gastos públicos e nova recessão bateu à porta do país, entre 1981 e 1983, quando, outra vez, o Brasil recorreu ao FMI.

Em 1984 o movimento pelas "Diretas Já” inflamou e tomou conta das ruas de todo o país. O ano de 1985 iniciou com uma situação de um certo alívio para a economia e também pela esperança frente ao primeiro governo civil, depois de mais de vinte anos. Assim, finalizou-se um período político obtuso e que não deixou saudades.

A esse cenário nevrálgico é que dirigimos nosso olhar, auxiliado pelas revistas já mencionadas. Ou seja, passamos a ter como objeto de análise textos que contavam um pouco da realidade não só do país, mas do mundo, obviamente, de acordo com o ponto de vista de cada uma das revistas estudadas. 


\section{CAPÍTULO 2 - A IDEOLOGIA E A MÍDIA IMPRESSA}

Vou voltar

Sei que ainda vou voltar

Para o meu lugar

Foi lá e é ainda lá

Que eu hei de ouvir cantar

Um sabiá

Chico Buarque- 1968

\subsection{A Ideologia e seus variados conceitos}

O conceito de ideologia, além de bastante amplo em sua acepção, é extremamente utilizado em diversos contextos e situações, como também abordado à luz de vários campos científicos, na área das humanidades.

Num dos dicionários pesquisados por nós, o político, a ser adiante mais explorado, há a afirmação de que tanto na linguagem política como na linguagem filosófica, social e político-científica, não existe nenhuma outra palavra que possa ser comparada à ideologia, pela freqüência com a qual é empregada e, ainda mais, pela gama de significados diferentes a ela atribuídos.

O termo ideologia, entendido por alguns estudiosos como equivalente ao ocultamento da realidade, desde o século XVIII, apresentou também um aspecto pejorativo. Isso se deveu ao uso da palavra ideologia por Napoleão, num discurso ao Conselho de Estado, em meados do século XIX, em que atribuiu todas as desgraças pelas quais passava a França, em virtude da ideologia, a que se referiu como tenebrosa metafísica, maléfica por querer fundar sobre suas bases a legislação dos povos, em vez de adaptar tais idéias ou ideais ao conhecimento e às lições de História.

Alguns outros estudiosos vêem o conceito sob dois significados. Por um lado, ideologia continua sendo aquela atividade filosófica-científca que estuda a formação das idéias a partir da observação das relações do homem com o mundo; por outro lado, a ideologia passa a significar o conjunto de idéias de uma época. 
Para uma mais aprofundada exploração acerca dessa terminologia, lançaremos mão de quatro significativas referências bibliográficas e suas respectivas atribuições para o que se entende por ideologia.

Segundo o Dicionário Aurélio (s/d):

Ideologia- Ciência da formação das idéias; tratado das idéias em abstrato; sistema de idéias; sistema segundo o qual a sensação é a única origem dos nossos conhecimentos; conjunto das convicções e convenções filosóficas, religiosas, jurídicas, sociais e políticas relacionadas com a situação social dos seus representantes dentro da sociedade.

Já no Dicionário do Houaiss (2001):

Ideologia- Ciência proposta pelo filósofo francês Destutt de Tracy (1754 - 1836) nos parâmetros do materialismo iluminista, que atribui a origem das idéias humanas às percepções sensoriais do mundo externo; no marxismo, conjunto de idéias presentes nos âmbitos teórico, cultural e institucional das sociedades, que se caracteriza por ignorar a sua origem materialista nas necessidades e interesses inerentes às relações econômicas de produção e, portanto, termina por beneficiar as classes sociais dominantes; totalidade das formas de consciência social, o que abrange o sistema de idéias que legitima o poder econômico da classe dominante (ideologia burguesa) e o conjunto de idéias que expressa os interesses revolucionários das classes dominada (ideologia proletária ou socialista); sistema de idéias (crenças, tradições, princípios e mitos) interdependentes, sustentadas por um grupo social de qualquer natureza ou dimensão, as quais refletem, racionalizam e defendem os próprios interesses e compromissos institucionais, sejam estes morais, religiosos, políticos ou econômicos; conjunto de convicções filosóficas, sociais, políticas etc. de um indivíduo ou grupo de indivíduos; ciência que tem por objeto de estudo as idéias, doutrina que inspira ou parece inspirar um governo ou um partido.

Com referência a um dicionário de especialidade, recorremos ao Dicionário de Política de Bobbio, Matteuci, Pasquino, (1995), em que Bobbio divide o termo ideologia, no que chama de "significado fraco" e "significado forte". Para tanto, ideologia, em seu sentido fraco diz respeito aos sistemas de crenças políticas: um conjunto de idéias e de 
valores respeitantes à ordem pública e, tendo como função orientar os comportamentos políticos coletivos. Já o que afirma ser o significado forte do termo tem origem no conceito de ideologia de Marx, entendido como falsa consciência das relações de domínio entre as classes.

Para os autores do Dicionário de Política, a ideologia, no sentido fraco, tem o pretenso caráter de neutralidade, já no sentido forte é um conceito negativo que denota precisamente o caráter mistificante de falsa consciência de uma crença política. Os autores ainda acreditam haver uma outra distinção, que concerne à questão da ideologia no conhecimento e na política. Para eles, na ideologia do conhecimento o problema é se o conhecimento do homem é condicionado ou distorcido ideologicamente e em que grau o pode ser. Já a ideologia na política apresenta como problema se esta é um aspecto essencial da política e, uma vez concluído que seja, o que ela é e como pode ser explicada. Nesse caso, parece importar não seu valor de verdade, mas o valor funcional da ideologia.

Restringindo mais o olhar para o termo em questão, buscamos uma outra fonte e selecionamos parte do que se compreende por ideologia, inserida na área de pesquisa da AD de Linha Francesa, já que nossa pesquisa tem por aspecto central uma leitura de textos veiculados em revistas, que, de uma forma ou de outra, apresentam marcas ideológicas das instituições a que representam.

Foucault posiciona-se frente à ideologia, relacionada à ciência, da seguinte forma (1987, p. 210 e 211):

\footnotetext{
... a questão da ideologia proposta à ciência não é a questão das situações ou das práticas que ela reflete de um modo mais ou menos consciente; não é tampouco, a questão de sua utilização eventual ou de todos os empregos abusivos que se possa dela fazer; é a questão de sua existência como prática discursiva e de seu funcionamento entre outras práticas. Estudar o funcionamento ideológico de uma ciência para fazê-lo aparecer e para modificá-lo não é revelar os pressupostos (...) é colocá-la novamente em questão como formação discursiva; é estudar (...) o sistema de formação de seus objetos, tipos de enunciação conceitos e escolhas teóricos.
}

Uma abordagem mais ampla sobre o conceito pudemos verificar, em Charadeau, \& Maingueneau. Dicionário de Análise do Discurso. (2004, p. 267 e 268) encontramos: 
Ideologia- (em Análise do Discurso) Na análise do discurso francesa dos anos 6070, a ideologia é um conceito central. O filósofo marxista Althusser desenvolve então uma teoria das ideologias, segundo ele, a ideologia está ligada ao inconsciente pelo viés da interpretação dos indivíduos em sujeitos (...)

Referindo-se ao mesmo tempo ao marxismo e à teoria lacaniana do inconsciente, a maior parte dos fundadores do que se chama correntemente a análise do discurso "à francesa" inscrevem-se no quadro dessa teoria. É em torno de Pêcheux que, de 1969 a 1983, lingüistas, historiadores e filósofos se esforçam para articular teoria do discurso e teoria das ideologias (...) essa articulação se cristaliza em algumas fórmulas que marcam época. Primeiro, é o empréstimo de "formação* discursiva" de Foucault e sua reformulação no campo do marxismo (...) Em seguida, a definição do pré-construído* cuidadosamente distinguido da pressuposição* como “impensado do pensamento" (...) e a colocação em funcionamento da noção de interdiscurso* como o que faz o laço entre ideologia, inconsciente e discurso (Pêcheux, 1975, p. 146)(...).

Charadeau e Maingueneau (2004) exploram o conceito amplamente, além de o dividirem, de acordo com seu uso, no decorrer do tempo*. ${ }^{3}$ Assim, reportam-se aos anos de 60 e 70 para se referirem à ideologia e, para tanto, recuperam um nome capital, o qual explora largamente o conceito de ideologia, trata-se do filósofo Louis Althusser, que produziu o que chamou de nota, publicada em 1970.

Se para certos autores ideologia pode ser entendida como sinônimo de teoria, não pode ser vista como sinônimo de subjetividade, oposta à objetividade, por ser um fato social, justamente se levarmos em conta que é produzida pelas relações sociais. A ideologia demonstra razões determinadas para surgir e se conservar.

Althusser escreveu os "Aparelhos Ideológicos do Estado: nota sobre os aparelhos ideológicos de Estado (AIE)”. Nesse trabalho, o autor estabelece a relação entre ideologia e instituições, aborda os mecanismos de sujeição que, de uma forma ou de outra, atinge todos os indivíduos de uma sociedade. De acordo com o autor, sujeição deve ser compreendida como um mecanismo com duplo efeito: o agente se reconhece como sujeito e se sujeita a um sujeito absoluto.

2. Procedemos a um recorte do apresentado pelos autores, com base no que consideramos como mais relevante para nosso estudo. 
A ideologia é um dos instrumentos da dominação de classe e uma das formas da luta de classe. Para o autor, para que se mantenha a dominação, a classe dominante estabelece/produz mecanismos de perpetuação de reprodução das condições materiais, ideológicas e políticas de exploração. Se há luta de classes, obviamente existe mais de uma classe social. Chauí (1980) afirma que as classes sociais não são coisas nem idéias, mas são relações determinadas pelo modo como os homens, na produção de suas condições materiais de existência, separam-se no trabalho, instituem formas determinadas da propriedade, reproduzem e legitimam aquela divisão e aquelas formas por meio das instituições, sociais e políticas, representam para si mesmas o significado dessas instituições, com seus ideais, que exprimem e podem esconder o significado real de suas relações.

É possível afirmar que uma ideologia mostra-se mais ou menos eficaz, dependendo do aumento de sua capacidade para ocultar a origem da divisão social em classes e a luta de classes. Não é difícil que a ideologia da classe dominante seja percebida como tal pelos dominados, mesmo que estes notem que essa classe luta por interesses que lhes são exclusivos, essa percepção não altera a aceitação das idéias e valores dos dominantes, porque a tarefa da ideologia consiste em separar os segmentos dominantes e as idéias dominantes, fazendo com que apareçam como independentes uns dos outros.

Além disso, Althusser explora contundentemente a distinção do que designa por aparelhos ideológicos do Estado e aparelhos repressivos do Estado. Mais do que isso, Althusser estabelece uma clara distinção entre o poder de Estado e o aparelho de Estado (ideológico ou repressivo) e assevera (1985, p. 19):

Para fazer progredir a teoria do Estado é indispensável levar em conta não somente a distinção entre poder de Estado e aparelhos ideológicos de Estado, mas também uma outra realidade, que se encontra manifestamente ao lado do aparelho (repressivo) de Estado, mas se confunde com ele. Chamaremos essa realidade pelo seu conceito: os aparelhos ideológicos de Estado.

Ao longo de seu texto, esmiúça a ideologia, retomando, assim como Houaiss o fez, a primeira menção ao termo, feita pelo francês Destutt de Tracy, além de recuperar a concepção de Marx, autor este que concebe a idéia de ideologia de uma forma geral, uma 
vez que não separa a produção das idéias e as condições sociais e históricas nas quais são produzidas.

Nas considerações sobre uma ideologia em geral, Marx e Engels determinam o momento de surgimento das ideologias, quando ocorre a divisão social do trabalho e este se divide em trabalho material ou manual e trabalho intelectual. Para Chauí (1980), enquanto esses dois trabalhos estiverem separados, enquanto o trabalhador for aquele que "não pensa" ou que "não sabe pensar", e o pensador for aquele que não trabalha, a ideologia não perderá sua existência nem sua função.

Para Althusser, não há ideologia, como conceito geral, sendo assim, discorda dessa utilização da palavra e opta por um enfoque múltiplo do termo e se refere às várias ideologias e afirma que estas não existem no campo das idéias, visto que têm existência material.

Por existência material podemos deduzir a própria luta de classes, de suas experiências de luta, por exemplo. Ao estabelecer uma diferença entre ideologia em geral e ideologia em particular, Althusser postula que o que move o indivíduo - por si só - não é a ideologia em geral, mas as ideologias (práticas) concretas. O que importa é conhecer os mecanismos concretos de ideologias particulares, inscritas em práticas específicas e em instituições concretas.

Em diversos momentos de seu texto, Althusser reafirma o entendido por aparelhos ideológicos do Estado. Estes seriam mais do que somente objeto, seriam a materialização da luta de classes. Porém, via uma possibilidade de harmonia entre os aparelhos ideológicos e os aparelhos repressivos. Entretanto, esta só poderia ocorrer pelas mãos de uma ideologia dominante. A definição do que vêm a ser os aparelhos ideológicos do Estado, na teoria marxista, mostra-se um pouco diferente do que é entendido por Althusser (1985, p. 67):

... na teoria marxista, o aparelho de Estado (AE) compreende: o governo, a administração, o exército, a polícia, as prisões, etc., que constituem o que chamaremos a partir de agora de aparelho repressivo do Estado.

De toda forma, não há como confundir o aparelho ideológico do Estado e o aparelho repressivo do Estado, primeiro porque há um aparelho repressivo do Estado, ao passo que existe uma pluralidade de aparelhos ideológicos de Estado. O aparelho repressivo do 
Estado pertence inteira e unicamente ao domínio público, enquanto a maior parte dos aparelhos ideológicos do Estado remete ao domínio privado. Segundo, que os aparelhos ideológicos do Estado funcionam predominantemente por meio da ideologia, distinguindose dos aparelhos repressivos do Estado que funcionam primeiramente por meio da violência.

Quanto à função, assevera o autor que todos os aparelhos ideológicos do Estado concorrem para o mesmo resultado: a reprodução das relações de produção, ou seja, das relações de exploração capitalista. O papel dominante, para Althusser, cabe à escola, tendo em vista que (1985, p. 31):

Ela (escola) recebe as crianças de todas as classes em sua idade mais "vulnerável", inculcando-lhe saberes práticos envolvidos na ideologia dominante (...) Cada massa que "cai" do AIE está praticamente provida da ideologia que convém a seu papel na sociedade de classes (...) Grande parte dessa ideologia se aprende fora da escola, mas "nenhum aparelho ideológico de Estado dispõe, durante tantos anos, dessa audiência obrigatória (...) 5 a 6 dias em 7, à razão de 8 horas por dia, da totalidade das crianças da formação social capitalista.

É, para ele, papel essencial da escola inculcar a ideologia dominante, o que não quer dizer produzir essa ideologia. A finalidade da escola é ensinar, objetivando que, futuramente, certos indivíduos saibam dar ordens, a dirigirem-se adequadamente aos seus subordinados e, em relação a isso afirma (1985, p. 58):

... a escola (mas também outras instituições do Estado, como a Igreja e outros aparelhos como o Exército) ensina o "Know-how" mas sob forma que asseguram a submissão à ideologia dominante ou o domínio de sua prática.

Althusser objetiva, com seu livro, constituir uma teoria da ideologia em geral. Ele vê como objeto da ideologia não propriamente o mundo, mas as relações do sujeito com o mundo, com suas condições reais de existência. Então, levanta algumas teses:

I - A ideologia representa a relação imaginária dos indivíduos com suas condições reais de existência.

II - A ideologia tem uma existência material.

III - Não existe ideologia senão por meio do sujeito e para sujeitos. 
IV - Não existe prática senão por meio de e sob ideologia.

V - O aparelho ideológico de Estado que assumiu a posição dominante nas formações capitalistas maduras, após uma violenta luta de classe política e ideológica contra o antigo aparelho ideológico do Estado dominante é o aparelho ideológico escolar.

A partir de tais teses, é possível enunciar a teoria da interpelação do sujeito que, para muitos, é a contribuição original e real de Althusser à teoria da ideologia.

Para concluir o que exploramos acerca da ideologia, respaldados por vários filósofos entre outros estudiosos que, de uma forma ou de outra, abarcaram o conceito em questão, temos a crença de que ser partidário de uma dada ideologia significa optar por uma situação no mundo, de certa maneira, ser parcial com o que se acredita ou com o que se optou por defender por um motivo ou outro. Ou seja, atuar em sociedade é agir ideologicamente. Não apenas a atuação política, partidária ou não, é ideologia. Em todas as atividades sociais somos orientados, segundo certos valores de indivíduos, de classes ou até mesmo de sociedades inteiras.

Nossa opção por recuperar os conceitos atribuídos à palavra ideologia justifica-se, especialmente, na medida em que acreditamos construir o nosso próprio conceito para ideologia, "atravessados" por várias outras vozes, por uma polifonia. Assim, o que entendemos pelo termo, exposto no parágrafo anterior, derivou-se, certamente, desses pontos de vista dos teóricos conclamados para este trabalho.

\subsection{A Mídia Impressa}

Desde Gutemberg, o conhecimento, por meio da informação escrita, atingiu níveis astronômicos, em todo o mundo. Se especialmente nos dois últimos séculos o índice de analfabetismo vem caindo drasticamente, não podemos também dizer que ser alfabetizado é ter conhecimento, de forma geral. Contudo, desde que o homem tornou-se um leitor proficiente, busca incessantemente pela informação. Não que não o fizesse antes, na condição de analfabeto, mas o faz de forma mais autônoma e consciente, na medida em que se vê como cidadão.

Não é nosso objetivo levantar a questão do conhecimento, mas da ânsia pela informação. Como próprio da lei da oferta e da procura, em se havendo público para 
comprar informação, há que se produzir informação. Isso é assim há séculos, entretanto, os meios de comunicação se modernizaram, diversificaram-se e cada um deles conta com suas próprias ferramentas, para não só seduzir o público leitor/ouvinte/telespectador, como objetiva mantê-lo como público.

Nos dizeres de Charadeau (2006, p. 19)

As mídias acham-se (...) na contingência de dirigir-se (...) a um número planetário, se possível. Como fazê-lo a não ser despertando o interesse e tocando a afetividade do destinatário da informação?

As estratégias para conseguir dado público não são recentes, há décadas, por exemplo, já havia jornais em Portugal que ofereciam junto ao exemplar de determinado dia da semana uma revista do grupo; hoje, inúmeros outros brindes são oferecidos (de cds a canecas e talheres) em jornais e revistas, em muitos países, o que vemos como um dos procedimentos mais comuns na busca de fidelizar esse consumidor.

Com o aumento de leitores, houve uma ampliação das formas de produzir a informação impressa, que é o que nos interessa. Essa ampliação tem a ver com os variados públicos a que se destinam determinados periódicos, além dos interesses das empresas proprietárias dos jornais e/ou revistas, assim como a relação destas com quem representa o poder numa dada sociedade. Em síntese, a mídia, em qualquer uma de suas versões, é claramente ideológica.

Santos (2001) vê a posição dos jornalistas de maneira comprometidamente ideológica, uma vez que estes precisam decidir o que é normal, para poderem escolher o anormal; têm de decidir o que está certo, para poderem noticiar o que está errado. Nesse ato de escolha, os jornalistas remetem-se para seus próprios quadros de valores, ou referenciais ideológicos, além dos valores das empresas para as quais prestam serviços. Continua o autor (2001, p. 40):

É como se os meios de comunicação seguissem a estrutura narrativa de ficção, suprimindo elementos que contradigam a narrativa dominante, de modo a produzir um discurso com uma coerência ideológica interiorizada que reflicta uma certa visão de mundo. 
A análise de um período, por meio de documento da mídia impressa, que é nosso foco, se por um lado é rico e contundente, na medida em que há possibilidade de comprovação documental do que se quer apresentar, por outro lado deve ser trabalhado com crítica e precaução, já que não podemos nos esquecer de que a mídia, em grande parte das vezes, está ligada a interesses empresariais e, como tal, está a serviço de alguém, objetivando lucro.

Assim, precisamos ter em mente o objetivo primordial de uma empresa: conquistar e manter um público. Nessa medida, é difícil não considerar o aspecto ideológico de tal empresa, bem como de seus interesses e relacionamentos com o regime de governo do período em questão. É possível, apesar dessas precauções, analisarmos fatos pontuais, a partir do que se noticiou e por caminhos apresentados pela $\mathrm{AD}$, essa trilha não parece insólita. Brandão (2003, p. 21) afirma:

Lembremo-nos dos acontecimentos políticos ocorridos em maio de 1968, em que as indagações e a perplexidade diante dos fatos e dos discursos então produzidos fazem surgir um sentimento de urgência teórica e política que vai buscar na $\mathrm{AD}$ um modo de leitura para a interpretação desses eventos.

Enfim, da mesma forma que muitos outros pesquisadores, nós também compactuamos com a crença de que o Jornalismo detém a concessão de lugar de seleção e (re) construção da informação que objetiva (ou não) o conhecimento, detém o poder de dizer e de silenciar, de julgar e de eleger quem participa ativamente da definição do conhecimento, assim como quem é excluído desse processo. Com base nessas possibilidades de dizer, de julgar, de eleger, retomamos o apregoado por Bakhtin (2004), quanto ao caráter dialógico da palavra. Contudo, se a palavra é um signo dialógico por excelência, a mídia, de forma geral, configura-se, para nós, como um signo polifônico por excelência. É polifônica, na medida em que seu poder advém de valores, crenças, interesses apresentados por meio de distintas e variadas vozes.

Nossa intenção, nesta parte do capítulo, é priorizar uma visão sobre a mídia impressa, todavia não há como fazê-lo sem retornarmos para a questão da ideologia, vez por outra. Ao finalizar o aspecto ideológico tratado no início do capítulo, afirmamos o fato inquestionável de estarmos e nos colocarmos em dada sociedade, segundo certas 
orientações pessoais ou não. Tudo isso é levado em conta por órgãos da imprensa, para produzir determinado tipo de periódico: jornal ou revista.

De toda forma, busca-se a informação, que é para Charadeau (2006) a transmissão de um saber, por meio de um tipo de linguagem, passada de alguém que presumidamente detém o saber para outro alguém que não o possui. Continua o autor (2006, p. 72):

Como em todo ato de comunicação, a comunicação midiática põe em relação duas instâncias: uma de produção e outra de recepção. A instância de produção teria (...) duplo papel: de fornecer a informação (...) e de propulsor do desejo de consumir as informações, pois deve captar o público. A instância de recepção (...) deveria manifestar seu interesse e/ou seu prazer em consumir tais informações.

Para que um órgão de imprensa qualquer tenha repercussão e visibilidade, urge que se conheça quem é a pessoa que recebe as informações. É preciso saber quem é esse receptor para, de fato, atingi-lo. Normalmente, o receptor não é apenas o alvo ideal visado por quem fornece a informação.

A fim de conseguir atingir determinado público, além de presumivelmente conhecer o público-alvo, é necessário demonstrar que tem a competência para não reproduzir, mas para reconstruir um acontecimento. Nas palavras de Santos (2001, p. 7):

O Jornalismo, como de resto qualquer discurso supostamente não ficcional, não tem a ver com a reprodução dos acontecimentos, mas com a sua reconstrução. Não se trata de um juízo de valor, mas de uma constatação que deriva de um fenómeno muito mais vasto que abarca todas as áreas do conhecimento humano. De resto, o próprio discurso científico, regulado por métodos considerados de rigor, possui a mesma característica. Na base do problema estão fundamentalmente as nossas limitações na relação com a realidade.

Mas afinal o que é realidade, o que é verdade?

Kant, em relação ao Mito da Caverna de Platão, afirmava que do real, apenas vemos as sombras, não o próprio real. Por mais que o conceito de verdade seja não só questionável, às vezes, contestável, todo meio de comunicação vocifera-se como detentor de verdade, o que é um outro recurso para cooptar maior número de pessoas possível. 
Aliado ao dito compromisso de dizer a verdade, todas as mídias utilizam-se de seus portavozes, para que eles sejam como um tipo de "encarnação" da própria verdade.

A forma com que a mídia, por meio de textos, apresenta a verdade, o real, o conhecimento sobre algo, dá-se não pelo uso de uma palavra em detrimento de outra, mas por uma certa linguagem, que conta com uma estrutura específica e que para demonstrar seu valor, cada palavra não depende de si mesma, mas da relação que ela estabelece com as demais palavras e com a própria estrutura, que já fora afirmado antes por Saussure (1971), acerca do funcionamento da linguagem. Assim sendo, o sentido de um texto ou de parte dele é relativo.

Cumpre à imprensa, então, lançar mão de outros recursos, no intuito de atrair seus adeptos. No que diz respeito ainda à relação informação - imprensa - conhecimento, Ponte (2004) traz a voz de Foucault, que embora tenha poucas referências claras ao Jornalismo, coloca-se quanto ao conhecimento não como objeto ontológico, mas como processo constituído por enquadramentos conceituais em construção discursiva contínua. Foucault distingue conhecimentos criados ou reproduzidos nas notícias, o que se dá com disputa de significados por parte de fontes de informação, jornalistas e público. Sobre sua concepção de ordem discursiva, afirma que os procedimentos discursivos de exclusão e de imposição podem ser mobilizados na apreciação da cultura jornalística.

Se parece que a mídia é capaz de (quase) tudo para se fazer presente no dia-a-dia de todo cidadão, não há como esta escapar do que muitas instâncias da sociedade lhe acusam: de manipuladora. Cabem, então aos órgãos de imprensa, realmente, duas férreas batalhas, pois além de precisar estar inserida no cotidiano de milhões de pessoas, precisa mostrar-se imparcial e não manipuladora.

Assim, para se mostrar não só imparcial, mas também democrática, elege caminhos, muitas vezes eficazes, no que se refere ao cuidado com a auto-imagem. Na mídia impressa, uma forma de fazer isso se dá, por exemplo, por meio das cartas ao editor/ ao diretor/ ao jornal/ à revista. Há que se refletir, no entanto, acerca do tipo de seleção das cartas a serem publicadas, se foram ou não publicadas na íntegra, se não, quais os critérios para o recorte do que se publicou, entre outros vários fatores. O que ocorre é um simulacro de interação leitor/veículo de informação. Sobre essa simulação de interação, outra vez damos voz a Charadeau (2006, p. 124): 
Por mais que as mídias recorram a técnicas ditas interativas, não há diálogo e troca, somente o seu simulacro (...) não chega a uma relação de hierarquia, e apesar da qualificação de "quarto poder", que muitas vezes é atribuída às mídias, estas não podem (...) produzir um discurso de poder.

Silva (2007) questiona ainda se é possível, realmente, considerar a seção de cartas dos leitores como um espaço público. O fato está em causa, pois a autora não vê como certa a ocorrência de um debate. Aliado a esse pensamento, questiona quem são os leitores que escrevem para um jornal, para uma revista. De acordo com o estudo que realizou, pôde verificar, por exemplo, o ocorrido nos Estados Unidos. Os resultados mostram esses leitores como majoritariamente do sexo masculino, de meia idade ou mais velho, com formação acadêmica superior, bem empregado, conservador, norte-americano nativo, branco e residente há muito tempo na sua cidade.

As dúvidas da referida autora não param por aí, levanta outras, por exemplo se os leitores conseguem influenciar, por meio de suas cartas, o processo de formação das notícias; se o jornal / revista vê a seção de cartas como um fórum público alargado e como um espaço de interação com os leitores, além de acreditar, o que também temos a tendência, que os leitores com status social de relevância têm mais possibilidade de ver seus textos selecionados para publicação em detrimento de leitores comuns.

Se para alguns autores as mídias não podem assumir uma voz de poder, há quem a julgue capaz de grandes feitos/ efeitos/ conseqüências do que criou na produção de uma ou de algumas notícias. No que tange a essa capacidade midiática, Grillo (2004:20) retoma o papel da mídia frente a um movimento social:

É inegável o poder da imprensa de criar uma imagem positiva ou negativa de um movimento social, haja vista a opinião generalizada de muitas pessoas, contrárias ao MST, justamente pela imagem transmitida.

Há quem veja a relação entre imprensa e poder como constantemente instável. Talvez até porque tanto imprensa como poder oscilam em posicionamentos, tudo em nome de um interesse maior. Nunes (2007, p. 54) posiciona-se acerca da questão e menciona o ponto de vista de outra pesquisadora: 
A relação entre imprensa e poder é sempre tensa e conflituosa, movida por "altos e baixos". Isto porque segundo Maria Helena Capelato, "desde os seus primórdios a imprensa se impôs como uma força política. Os governos e os poderosos sempre a utilizam e temem; por isso adulam, vigiam, controlam e punem os jornais.

A função precípua da mídia é dar conta de acontecimentos recentes, estar o mais próximo possível do fato. Nesse aspecto, a mídia televisiva e radiofônica saem à frente, por contarem com o rico material da imagem e do som do ocorrido.

Como cada mídia conta com recursos próprios, a mídia impressa, composta por palavras sobre um papel, pode recorrer a outros efeitos, por meio de gráficos, pela composição de fotos, por desenhos. Enfim, cabe à mídia impressa um grande número de gêneros textuais. Bem verdade é que estes, apesar de progredirem, atualizam-se menos que os gêneros textuais da mídia televisiva. 


\section{CAPÍTULO 3 - A ANÁLISE DO DISCURSO, AS TEORIAS LINGÜÍSTICAS QUE ENFOCAM A INTERAÇÃO E OS GÊNEROS DO DISCURSO}

... a partir da análise do discurso (...) o estudo da constituição da memória histórica como processos discursivos salienta essa memória que é coletiva e, portanto, memória de todos.

Jean-Jacques Courtine

\subsection{A Análise do Discurso em seus primeiros momentos}

Parece inesgotável fonte de estudo de várias áreas das chamadas ciências humanas o homem e suas relações com o meio em que vive. A forma com que o ser humano se relaciona em seu meio social é possibilitada pela comunicação. Uma hipótese para que o motivo de essa relação inesgotável ocorra seja o fato de que tanto o homem como o meio estão em constante mudança. A linguagem, responsável pela intermediação homem/meio sofre intensa transformação, na medida em que ao se comunicar, o homem, reflexo do que vive, imprime tais mudanças no ato de comunicação, para que esta se efetive.

Nesse sentido, a Lingüística é uma ciência que serve de base para muitas pesquisas, no intuito de responder a questões relativas ao homem e sua linguagem, ou seja, sua forma de ser e estar no mundo.

Ao se levar em conta as relações homem-mundo, os estudos que privilegiavam apenas os aspectos lingüísticos não mais contemplavam os trabalhos de muitos cientistas da linguagem e das Ciências Humanas, de uma forma geral. Assim, fenômenos lingüísticos começaram a ser interpretados, de maneira a se considerar o aspecto ideológico. Uma porta aberta para estudos dessa natureza se deu por meio da Análise do Discurso de Linha Francesa, esta inserida numa linha da Lingüística, a chamada Teoria do Discurso.

Um olhar social e ideológico, respaldado por discursos que perpassam as relações do homem com o seu meio é, em outras palavras, o fomento da História, são os recursos de que a História dispõe para se firmar como disciplina que possibilita uma reflexão, via de regra datada por inúmeros fatos. No que diz respeito a uma observação dos discursos, Chartier (1988, p. 41) afirma: 
Os discursos (...) constituem não o único, mas o mais maciço dos materiais da História. Nenhum discurso pode ser manejado sem ser submetido ao duplo questionário crítico e genealógico proposto por Foucault, que visa a identificar suas condições de possibilidade e de produção, seus princípios de regularidade, suas imposições e suas apropriações.

Como a Análise do Discurso, doravante denominada AD, servir-nos-á de referencial teórico, ao longo de nosso trabalho, entendemos como relevante fazer um breve histórico de sua origem, já na década de 50, quando houve um movimento, na tentativa de constituição da Análise do Discurso como uma disciplina. Nesse período, o trabalho de Harris foi de suma importância, ao propor uma análise que superasse os limites da frase. Contudo, aos olhos de muitos teóricos, o trabalho de Harris era uma continuação da teoria lingüística, por não levar em conta, nas análises, questões sócio-históricas que, de acordo com Brandão (1993), vão distinguir e marcar posteriormente a AD.

Para Courtine, o surgimento da problemática do discurso no interior da Lingüística francesa é contemporâneo à conjuntura política dos anos 1968 - 1970, bastante influenciada por fatos ocorridos em maio de 68. Tendo em conta tais questões, afirma, ainda, o autor (2006, p. 9):

Tomei como ponto de partida a seguinte tese: a Análise do Discurso é uma prática da leitura dos textos políticos, e até mesmo um pouco mais: uma política da leitura.

O inquestionável é, entretanto, que o caráter mais político do que lingüístico da $\mathrm{AD}$ se dá a partir da década de 70. Na França, especialmente, esse posicionamento mais político tem muito a ver com o que as pesquisas lingüísticas e sociolingüísticas tiveram em relação com o marxismo do fim dos anos 60.

A AD de linha francesa, para Maingueneau (1987), citada por Brandão (1993), emerge, realmente, na década de 60, dentro dos cânones da conjuntura intelectual francesa, em que se entendeu como necessária a relação entre a Lingüística, o Marxismo e a Psicanálise. Assim sendo, surge uma teoria de cunho interdisciplinar, na medida em que passou a ser tema de interesse não só de lingüistas, mas de historiadores e de psicólogos. 
Silva (2007) entende que tanto o desenvolvimento da Lingǘstica como o da $\mathrm{AD}$ mostraram que uma abordagem da linguagem que não levasse em conta o seu contexto era não só parcial, como inadequada. Dessa forma, o que a autora chama de metodologia multidisciplinar por natureza, considera o discurso como uma forma de prática social, o que implica a existência de uma relação dialética entre um acontecimento discursivo particular e as situações, instituições e estruturas sociais que o enquadram.

Ao se falar em AD, além de imprescindível delimitar os conceitos mencionados anteriormente, vemos como uma área que contempla muitos estudos, por se apoiar no que se refere ao aspecto político. A esse respeito, também afirmam Gadet e Hak, na apresentação do livro Por uma análise automática do discurso - uma introdução à obra de

\section{Michel Pêcheux.}

Gadet e Hak (1997, p. 89) asseveram:

$\mathrm{AD}($...) nasce na crença em uma visão de intervenção política, porque aparece como portadora de uma crítica ideológica apoiada em uma arma científica (...) uma característica da Análise do Discurso Francesa, cuja forma acabada é a de Michel Pêcheux, com o apoio sobre uma teoria do discurso. "Para ele, é impossível a Análise do Discurso sem sua ancoragem em uma teoria do sujeito, tema que também deve ser visto como um lugar problemático, que deve ser constituído.

Após essa premissa do que se chamou inicialmente de $\mathrm{AD}$, e de retornarmos para a França, cumpre que nos reportemos, enfim, a Michel Pêcheux, com o objetivo de expor um breve percurso do que entendemos como fundamentos teóricos que se coadunam.

A década de 60 foi um momento de muita reflexão acerca do que estava vigente em termos de teorias científicas, bem como de ideologias. Nesse período, o Estruturalismo, tanto na Lingüística, como nas Ciências Humanas, de maneira geral, ainda gozava de grande prestígio. Pêcheux, por sua vez, caminha mais à frente, de certa forma negando uma visão reducionista, no que se referia à linguagem. Como era um momento de clara ruptura, a afirmação de Pêcheux de que, num certo modo, toda ciência é a ciência da ideologia com a qual rompe, parece fazer sentido. $\mathrm{O}$ ponto central de seu estudo dizia respeito às Ciências Sociais, de forma geral, que, para ele, não eram vistas realmente como ciências, mas como ideologias. Como sintetiza Orlandi (1997), para a AD não há discurso sem sujeito nem 
sujeito sem ideologia. A autora (1997, p. 16) ressalta o ponto de vista de Pêcheux, nome capital da Análise do Discurso:

... Pêcheux (...) o que singulariza o pensamento desse autor, e estabelece conseqüentemente a sustentação fundamental da análise de discurso, é o lugar particular que ele dá à língua, de um lado, em relação à ideologia, que ele trata no domínio conceptual do "interdiscurso", e, de outro, ao inconsciente, na relação da língua com o que seria a "lalangue" (Lacan) (...) visa-se justamente o outro lado dessa relação: o discurso como lugar de contato entre língua e ideologia.

Ponte (2004) menciona esse período de franca efervescência como a "viragem lingüística", expressão também comum a partir dos anos 60. Segundo a autora, é um momento em que se retomam e se desenvolvem conceitos introduzidos pela Escola de Chicago, no início do século XX, no que se refere ao interacionismo e a formas de pesquisa social, e continua (2004, p. 10):

... o interaccionismo e a pesquisa social têm em conta os mundos de experiências, como as pessoas se exprimem, como exprimem (...) o senso comum e os seus pressupostos de inclusão e de exclusão com que operam (...) o conhecimento. Esta viragem integra contributos da Filosofia Pragmática (em particular Austin, 1962) com a substituição da sua análise formal por uma análise de sua realização em contexto. Trata-se de uma viragem do texto para o discurso, da linguagem para o social, do enunciado para a enunciação e as suas condições de produção e de recepção e de que é constituinte nomeadamente o dialogismo de Bakhtine.

Nessa direção também parece seguir Benveniste, que já apontava uma brecha na fenda aberta no Estruturalismo, que não levava em conta o sujeito, uma vez que a língua era como materializada, como se ela falasse por si. Benveniste, além do reconhecimento do papel da enunciação, apresenta o princípio da alteridade.

A própria abordagem do tema discurso mostra-se abrangente, na medida em que este só existe se houver a aproximação entre um eu e um tu. Aliado a isso, deve-se entender como uma das características da AD de linha francesa a historicidade. Começa-se, então, a analisar não um discurso solto, mas inserido em um determinado contexto, este que se constrói no e pelo discurso, bem como se julga determinante, também, sua condição de 
produção. Em outras palavras, o ponto que possibilita uma articulação entre fenômenos lingüísticos e processos ideológicos é o discurso.

Acerca do termo discurso, encontramo-lo atravessado por uma gama polifônica de teorias relativas a ele. Assim, consideramo-lo, quanto ao seu conceito e função, como um ato comunicativo, em que estão envolvidos ao menos dois interlocutores. O discurso é uma atividade que produz sentido, a partir de uma interação entre os indivíduos envolvidos em uma comunicação. O discurso leva em conta, como já afirmado antes, além dos fatores lingüísticos, os extralingüísticos. A contextualização é própria do discurso, que é produzido por um sujeito para o qual a alteridade é imprescindível, quando se busca um discurso que faça sentido.

Assim, o discurso é interativo. Nessa medida, é dialógico na essência. Se é verdade que para nos comunicar dialogamos com o outro, é também verdade que o diálogo não se restringe a um outro indivíduo, mas perpassa mesmo outros discursos. Enfim, o discurso ascende a um caráter ainda mais amplo, graças a essa polifonia.

A AD de linha francesa mostra-se adequada a certos aspectos que pretendemos abordar em nossa análise, uma vez que propõe a articulação entre a materialidade lingüística e aspectos externos à língua, como o sócio-histórico e o político, que são, naturalmente, guiados por uma ideologia. Todavia, mesmo ao se falar da AD de linha francesa, é preciso delimitá-la melhor, por ter se mostrado diferente, de certa forma, no decorrer das fases pelas quais passou.

Quanto à especificidade da $\mathrm{AD}$, surge uma questão: percebeu-se a necessidade de delimitar essa teoria, para melhor entender os processos de análise de determinadas condições de produção. Segundo Brandão (1993, p. 18):

Dessa forma, a linguagem passa a ser um fenômeno que deve ser estudado não só em relação ao seu sistema interno, enquanto formação lingüística a exigir de seus usuários uma competência específica, mas também enquanto formação ideológica, que se manifesta através de uma competência sócio-ideológica.

Para que enfim houvesse um quadro teórico próprio à $\mathrm{AD}$, entendeu-se como condição sine qua non que este aliasse aspectos lingüísticos aos sócio-históricos. Dessa maneira, os conceitos capitais da teoria são a ideologia e o discurso. 
No que se refere à ideologia, a $\mathrm{AD}$ alicerça-se em Marx, ao passo que para o discurso sua base será Foucault. Então, para este, discurso define-se por um conjunto de enunciados que apresenta seus princípios de regularidade em uma formação discursiva. Ainda para ele, a análise de uma formação discursiva consistirá na descrição dos enunciados que a compõem. Explicitando melhor o conceito, Foucault (1987, p. 134):

... discurso é um conjunto de enunciados, na medida em que se apóiem na mesma formação discursiva (...) é constituído de um número limitado de enunciados para os quais podemos definir um conjunto de condições de existência.

Então, é a partir desses dois teóricos que Pêcheux constrói seus conceitos.

Se a $\mathrm{AD}$ parece contemplar o que presumimos como imprescindível para compor nossa base de sustentação teórica, há que se fazer referência a outros estudos, os quais permeiam nossa pesquisa, o da Sociolingüística Interacional assim como aspectos relativos ao gênero. Frisamos, novamente, no entanto, que tais estudos não são nosso alvo teórico, mas referências significativas que nos serviram como elementos propulsores de uma reflexão mais amadurecida, no que tange ao estudo mais aprofundado, como o que pretendemos com este trabalho.

Cumpre retomarmos certos preceitos que caracterizaram os primeiros estudos da, até então, nova área da Lingüística, a Sociolingüística. De acordo com alguns estudiosos, na tentativa de ultrapassar os limites irreais de um discurso perfeito, alguns lingüistas partiram para um trabalho mais próximo do que ocorre com as pessoas em situação de comunicação corriqueira.

O sociolingüista está interessado nas interações entre os grupos dentro da cultura que se reflete pelos fenômenos lingüísticos de determinada espécie. Para alguns pesquisadores, a Sociolingüística representa para a Lingüística um passo à frente, por levar em conta a linguagem em seu uso.

Os estudos relacionados à Sociolingüística se desenvolveram bastante nas décadas de 50 e 60, nos Estados Unidos. Muito do interesse pela área se deu, possivelmente, por causa da grande divulgação dos estudos de comunicação, também devido à necessidade de uma maior aproximação entre povos e, sem dúvida, pela divulgação de trabalhos de Sociologia e de Lingüística. Conforme Preti (1994, p.13): 
... estudiosos como William Bright, Dell Hymes, Willian Labov, J. Gumperz (...) entre outros, têm conduzido a Sociolingüística aos mais diversos caminhos, no estudo do que os especialistas americanos costumam chamar de dialeto social, ou seja, habitual subvariedade da fala de uma dada comunidade, restrita por operações de forças sociais a representantes de um grupo étnico, religioso, econômico ou educacional específico.

Dos nomes citados, entre os de maior repercussão encontra-se Labov. Muitos estudiosos, seguindo Labov, encaminharam a disciplina, no que se refere ao seu aspecto quantitativo, o qual não será trabalhado neste estudo. Aqui, reportar-nos-emos, em algumas situações específicas, a trabalhos voltados à Sociolinguiística Interacional, exatamente por privilegiar a interação.

Parece-nos necessário, no momento, que apresentemos nosso ponto de vista para o que entendemos por interação. Interação é uma efetiva comunicação entre um locutor e um interlocutor, independentemente do meio pelo qual a mensagem é transmitida. Se muitos acreditam que a interação real só ocorre na situação face a face, nós avaliamos que uma manifestação escrita só existe por ser direcionada a alguém (singular ou coletivo), é uma interação por atingir, de alguma forma, o outro. Se é mais ou menos eficaz, por motivo de sua estrutura, de seu conteúdo, de seu contexto, isso também é verdade numa situação face a face, numa situação de conversa, de construção de texto oral.

Ao entendermos que a interação é um inconteste ato social, damos voz a Silva (2007, p. 122) que considera:

Ao produzir ou emitir um texto, o homem realiza um acto social, fazendo com que a comunicação tenha lugar nessa interacção social na qual o destinatário, mediante a enunciação, é influenciado de alguma maneira pelo emissor.

\subsection{A Análise do Discurso e sua consolidação}

Explorar questões que envolvam aspectos discursivos exige, sempre, que retomemos o conceito de discurso para um determinado autor. Já retomado o conceito de discurso para Foucault, nas páginas anteriores, são também centrais para a $\mathrm{AD}$ os conceitos de enunciado e de enunciação. Objetivando explicitar a maneira com que explora o 
enunciado, Foucault (1987) levanta, inicialmente, alguns questionamentos acerca da noção de enunciado. Após esses questionamentos, aventa a hipótese de que seria possível afirmar haver enunciado sempre que se pudesse reconhecer e isolar um ato de formulação, o ato ilocutório, ou seja, o que se produziu pelo próprio fato de ter sido enunciado, em dadas circunstâncias. O autor, então, afirma (1987, p. 98):

... a enunciação não é uma unidade do mesmo gênero da frase, proposição ou ato de linguagem; não se apóia nos mesmos critérios; mas não é tampouco uma unidade como um objeto material poderia ser, tendo seus limites e sua independência (...) ele é indispensável para que se possa dizer se há ou não frase, proposição, ato de linguagem: e para que se possa dizer se a frase está correta (ou aceitável, ou interpretável), se a proposição é legítima e bem constituída (...)

De acordo com a autor, o enunciado tem a particularidade de poder ser repetido, no entanto, sempre em condições estritas e continua (1987, p. 121):

... o enunciado (...) aparece com um status, entra em redes, se coloca em campos de utilização, se oferece a transferências e a modificações possíveis, se integra em operações e em estratégias onde sua identidade se mantém ou se apaga.

Alguns estudiosos entendem, conforme Grillo (2004), que a enunciação pressupõe e estrutura, simultaneamente, o universo social que a torna exequíivel, pelo fato de os sujeitos produzirem a ordem social, ao participarem das interações conversacionais. Como o conceito de enunciação é fundamental também para $\mathrm{AD}$, retomamos o que afirmam sobre ela Charaudeau e Maingueneau, (2004, p. 193):

A enunciação constitui o pivô da relação entre a língua e o mundo: por um lado, permite representar fatos no enunciado, mas, por outro, constitui por si mesma um fato, um acontecimento único definido no tempo e no espaço (...) Faz-se geralmente referência à definição de Benveniste (1974:80), que toma a enunciação como colocação em funcionamento da língua por um ato individual de utilização, que o autor opõe a enunciado. (...)

(...) A reflexão sobre a enunciação pôs em evidência a dimensão reflexiva da atividade lingüística: o enunciado só faz referência ao mundo na medida em que reflete $o$ ato de enunciação que o sustenta. Assim, as pessoas e o tempo do enunciado são selecionados em relação a sua situação de enunciação; desse modo, 
o enunciado possui o valor ilocutório que ele mostra por meio de sua enunciação.

A enunciação é marcada pela sua singularidade, uma vez que não se repete, já o enunciado pode ser repetido. Para Brandão (1993, p. 31):

As idéias de Foucault são fecundas na medida em que colocam diretrizes para uma análise do discurso. Mas verificar como se concretizam essas diretrizes, no nível lingüístico propriamente dito, é uma tarefa que deixa ao lingüista, e ele não a realiza uma vez que não tinha como preocupação central o enfoque do discurso enquanto problema lingüístico.

Para Foucault (1979), o discurso é o espaço em que saber e poder se articulam, na medida em que quem fala, fala de um lugar, a partir de um direito reconhecido institucionalmente. Assim, entende-se que o discurso é gerador de poder. No entanto, a produção desse discurso gerador de poder é controlada, selecionada, organizada e redistribuída por determinados procedimentos, que têm por função eliminar toda ameaça à permanência desse poder.

Parece não ser possível pensar o discurso sem levar em conta seu contexto, em outras palavras, é fato que o discurso só é pronunciado a partir de condições de produção dadas. No que tange às condições de produção, Courtine (1981) crê em três condições básicas para que essas condições de produção existam. São elas: a) inicialmente, parte-se da análise de conteúdo, praticada em especial na Psicologia Social; b) num segundo caso, originam-se, de forma indireta, da Sociolingüística, pelo fato de esta partir de variáveis sociológicas e, por último; c) conforme assevera Courtine (1981, p. 20) faz parte do discurso as frases:

... que foram pronunciadas ou escritas umas em seguida das outras por uma ou várias pessoas em uma só situação (...) as particularidades de personalidade que provêm da experiência do indivíduo em situações interpessoais, condicionadas socialmente.

Cumpre, então, verificar essas condições de produção, ou seja, há que se levar em conta o sujeito inserido em determinada situação e em nome, referência, resposta, crítica a 
que ele se pôs a proferir tal discurso. Nessa medida, consoante Pêcheux (1975), in Gadet e $\operatorname{Hak}(1997$, p. 77):

O processo discursivo não tem, de direito, início: o discurso se conjuga sempre sobre um discurso prévio, ao qual ele atribui o papel de matéria-prima, e o orador sabe que quando evoca tal acontecimento, que já foi objeto de discurso, ressuscita no espírito dos ouvintes o discurso no qual este acontecimento era alegado, com a "deformação" que a situação presente introduzida e da qual pode tirar partido.

Tomando por base o contexto, é preciso que entendamos, então, o seu entorno e/ou as ideologias que perpassam determinada situação. Assim, considerando-se a ideologia, mais uma vez vemos autores outros que não apenas os analistas do discurso de linha francesa, que compuseram seus trabalhos em algumas mesmas bases. É o caso de Bakhtin. Seus estudos se coadunam com a linha francesa, visto que o conteúdo de seus trabalhos permeia as Ciências Sociais, o que Pêcheux já apregoava em seus primeiros textos. Além de haver semelhança em determinados tópicos abordados pelo grupo, intitulado círculo de Bakhtin, como pela $\mathrm{AD}$, tanto num grupo como em outro, trabalha-se com a noção de sujeito, o conceito de enunciação e de enunciado e ainda a questão da formação discursiva, bastante explorada por Foucault. Acerca dessa articulação de idéias, Courtine (2006, p. 13) completa:

... a $\mathrm{AD}$ seria (...) um ramo da tradição historicista em Lingüística; ou mesmo um prolongamento da tradição francesa de sociologia da linguagem; ou ainda, ela se encontraria em germe na relação da Lingüística com a Literatura pela via dos formalistas russos e do círculo de Praga; mais adiante ainda, em gestação da reflexão marxista sobre a língua, como a de Lafarge ou de Voloshinov, ela teria nesse ínterim surgido (...)

Se dissemos que a questão da ideologia nos leva a perceber a relação clara entre o trabalho de vários analistas do discurso de linha francesa e Bakhtin faremos, no mínimo, uma afirmação reducionista. Deve-se levar em conta questões outras e fundamentais no trabalho de Bakhtin, ou seja, o dialogismo e a polifonia; no entanto, o diálogo, para Bakhtin, tem de ser visto de forma ampla, como ato de enunciação, independente de haver, ou não, interação face a face. Curi (1995) explica que o diálogo para Bakhtin não é a 
simples troca de fala entre interlocutores, mas um processo de autoconhecimento e de conhecimento do outro, uma forma de exercitar a alteridade, levando-se em conta a consciência que se tem de si e do outro. No que diz respeito, especialmente, à enunciação, Bakhtin* $^{4}$ (2004, p. 112) afirma:

... a enunciação é o produto da interação de dois indivíduos socialmente organizados e, mesmo que não haja um interlocutor real, este pode ser substituído pelo representante médio do grupo social ao qual pertence o locutor (...) não pode haver interlocutor abstrato (...) O mundo interior e as reflexões de cada indivíduo têm um auditório social próprio bem estabelecido.

Bakhtin trabalha a relação com o outro, no discurso, devido à força que o outro tem no seu discurso. A força que esse outro exerce sobre dado sujeito depende, contudo, do tipo de relação estabelecida entre ambos, depende do grau de poder de cada um dos envolvidos naquela dada situação comunicativa, ressaltando-se, ainda, a ideologia que atravessa a situação. O simples ato de viver configura-se, necessariamente, na participação de um constante e inconcluso diálogo.

No que diz respeito à polifonia, Bakhtin explora esse conceito, das várias vozes que permeiam um discurso, em seu livro "Problemas da Poética de Dostoiévski”, com versão para o português de 1981. No livro, o autor tratou do aparecimento de um gênero, o romance polifônico, no qual era possível depreender algumas vozes orquestradas, de forma pessoal ou institucional, ou até cultural da sociedade russa da época de Dostoiévski. Segundo Curi (1995), Bakthin considerou Dostoiévski o criador desse gênero, por ter feito com que, ao mesmo tempo, autor ou narrador se multiplicasse e dessa forma fosse possível verificar que as personagens também assumiam personalidade e consciência, por ser importante para Dostoievski a visão de mundo da personagem. É capital entender a personagem no mundo, sua tomada de consciência, para que a emergência de sua voz se faça distinta das demais e, ainda, audível.

\footnotetext{
${ }^{4}$ Apesar de sabermos que alguns estudiosos, por exemplo os do grupo de Interacionismo Sociodiscursivo, liderado por Jean-Paul Bronckart, acreditarem, hoje, que muito do que se conhece por teoria formulada por Bakhtin, seria, de fato, de autoria de Volochínov, não entraremos nessa questão e reportar-nos-emos a conceitos propostos por Michael Bakhtin. Essa polêmica esteve em pauta, em alguns momentos, no Segundo Encontro de Interacionismo Sociodiscursivo, ocorrido em outubro de 2007, na Universidade Nova de Lisboa; evento de que participamos.
} 
Ainda em Bakhtin, em seu livro "A Estética da Criação Verbal” (2003), o autor relaciona a noção de gênero ao uso do discurso numa determinada esfera da vida humana e afirma que o indivíduo utiliza o discurso em cada momento da vida, mas não o faz da mesma maneira, pois a cada uma das esferas da atividade social vai corresponder um tipo de discurso. Por meio de nossa competência nas atividades cotidianas de linguagem, é comum do ser humano, que vive em sociedade, comportar-se em consonância com a situação, em termos de uso do gênero de discurso e suas respectivas especificidades, mais ou menos fixas. A esse respeito, podemos recuperar Pêcheux (1975), in Gadet \& Hak (1997, p. 82):

... A e B designam lugares determinados na estrutura de uma formação social, lugares dos quais a sociologia pode descrever o feixe de traços objetivos característicos, assim, por exemplo, no interior da esfera da produção econômica, os lugares do "patrão" (diretor, chefe da empresa, etc.), do funcionário de repartição, do (...) operário são marcados por propriedades diferenciais determináveis.

Nossa hipótese é a de que esses lugares estão representados nos processos discursivos em que são colocados em jogo (...) o que funciona nos processos discursivos é uma série de formações imaginárias que designam o lugar que A e B se atribuem cada um a si e ao outro, a imagem que eles fazem de seu próprio lugar e do lugar do outro.

Considerar a posição do outro, de uma forma mais geral, é o mesmo que admitir como importante num discurso as condições de produção, no entanto, tais condições originam-se, de dada maneira, da Sociolingüística, na medida em que aceita variáveis sociológicas como responsáveis pelas condições de produção. Assim, de acordo com alguns teóricos, as condições de produção têm uma origem implícita nos estudos de Harris, já na década de 50.

No estudo em questão, não há propriamente o termo 'condições de produção', mas o termo 'situação', ao referir-se como parte do discurso somente frases ditas ou escritas, em seqüência, por uma ou mais pessoas, em uma única situação. Segundo Brandão (1993, p. $35)$ :

Essa noção de situação se mostra insuficiente e ainda bastante próxima da formulação de $\mathrm{CP}$ elaborada pela análise de conteúdo 
da psicologia social ou da sociolingüística. (...) Segundo Courtine (1981), essa tentativa de definição da noção de CP, esboçada por Pêcheux, não rompe, entretanto, com as origens psicossociológicas já assinaladas na fase anterior. Para ele, os 'termos 'imagem' ou 'formação imaginária' poderiam perfeitamente ser substituídos pela noção de 'papel' tal como é utilizada nas "teorias do papel" herdadas da sociologia funcionalista de Parsons ou ainda do interacionismo psicossociológico de Goffman.

Portanto, considerando-se o outro e o papel que exerce no discurso, cumpre-se que passemos a explorar o eu que se coloca de determinada maneira, em uma dada situação, em virtude de sua relação com o outro. Sendo assim, recuperamos o conceito de subjetividade em Benveniste.

Este incorporou aos estudos lingüísticos o conceito de subjetividade. O aspecto subjetivo vem sendo bastante explorado em muitos trabalhos, tendo em vista uma preocupação maior não com o texto enunciado, mas com o próprio ato de produzir um enunciado, ou seja, considerando-se o processo e não apenas o produto.

Benveniste (1995), para definir enunciação, retoma a língua e a entende como que não concretizada, materializada somente no ato de enunciação. Tomando por base a situação enunciativa, passa a explorar mais detidamente o sujeito, em outras palavras, conforme Brandão (1993, p. 47) “introduz aquele que fala na sua fala”.

Para o estudioso, a subjetividade é a possibilidade de o locutor se colocar como sujeito do seu discurso, propiciado pelo uso da língua. Ainda em Brandão (1993, p. 49):

... o sujeito em Benveniste é um eu que se caracteriza pela sua homogeneidade e unicidade e se constitui na medida em que interage com um tu - alocutário- opondo-se à não-pessoa, ele (eutu $x$ ele). Apesar desse tu ser complementar e indispensável, na relação é o eu que tem ascendência sobre o tu.

Ao refletirmos mais acerca de quem é e como é esse sujeito numa relação comunicativa, compactuamos com a opinião de muitos estudiosos, ao admitirem não ser o sujeito inteiramente livre, nem tampouco assujeitado, no sentido de pertencer a uma determinada classe social, com mesmos valores, crenças, portanto é um sujeito de uma dada formação discursiva comum. Nossa opção pela AD como base teórica pode muito bem ser justificada novamente chamando à tona Brandão (1993, p. 83), quando esta conclui: 
... o desafio a que a AD se propõe é o de realizar leituras críticas e reflexivas que não reduzam o discurso a análises de aspectos puramente lingüísticos nem o dissolvam num trabalho histórico sobre a ideologia. Ela é interdiscursiva (...) disciplina em que o lingüístico é o lugar, o espaço, o território que dá materialidade, espessura a idéias, conteúdo, temáticas de que o homem se faz sujeito, não um sujeito ideal e abstrato, mas um sujeito concreto, histórico, porta-voz de um amplo discurso social.

Entendemos como realizável e importante para nosso trabalho articularmos as questões relativas à $\mathrm{AD}$ acima elencadas, em especial as condições de produção, com a subjetividade e com os aspectos ideológicos, levando em conta também os pressupostos de Bakhtin, no que tange tanto à dialogia como à polifonia, que permeiam as situações comunicativas, bem como aspectos relativos aos Gêneros e conceitos explorados por um outro analista do discurso de linha francesa, Dominique Maingueneau.

Faz-nos sentido abordar aspectos da teoria de Maingueneau, tendo em vista o fato de este explorar certos conceitos como -ethos-, que nos aponta determinados caminhos para nossa interpretação de textos que constituem nosso corpus.

O conceito de ethos não é uma noção nova, foi desenvolvida na Retórica Antiga por Aristóteles e apropriada pela AD. É o fenômeno em que, por meio da enunciação, revela-se a personalidade do enunciador.

Brandão (1993) procura estabelecer certa distinção entre o conceito de ethos na sua origem, em Aristóteles, e sob o ponto de vista da AD. Na Retórica, o autor define o tom empregado pelo discurso, tendo em vista os efeitos que objetiva produzir sobre o auditório. Ainda na perspectiva da Retórica, o ethos era aplicado apenas aos textos orais. Já na AD, acredita-se que o sujeito não possui o controle de seu discurso, os efeitos são impostos pela formação discursiva, além disso, esse conceito, no ângulo da $\mathrm{AD}$, não se restringe somente ao texto oral, abarca também o texto escrito. Quanto à crença de o sujeito não possuir controle sobre o seu discurso, gostaríamos de ponderar essa afirmação, já que consideramos que este, além de ser, de certa maneira, atravessado por ideologias, em muitas situações é senhor consciente de seu discurso, possivelmente baseado em uma dada orientação ideológica .

Retomando o conceito de ethos, este faz parte, como o logos e o pathos, da trilogia aristotélica dos meios de prova da retórica. O que concluímos como relevante do conceito 
mencionado, reapropriado por Maingueneau, é porque o autor o entende também para o texto escrito, diferente da retórica antiga, que concebia o conceito no tocante à eloqüência jurídica ou aos enunciados orais.

Nesse sentido, entendemos como uma ferramenta apropriada, quando procedermos às análises que comporão este estudo, pois, afinal, desvendar 'personalidades' dos enunciadores de textos das revistas deve propiciar relevantes dados para nossa pesquisa. Nossa crença na possibilidade de uma leitura/interpretação dessa natureza se dá, tendo em vista também o que Foucault (1987, p. 31) afirma quanto ao fato de se encontrarem marcas de um e não de outro enunciado, a partir de uma dada formação discursiva e segue justificando seu ponto de vista:

... um conjunto definido de discursos (...) é tratado de tal maneira que se tenta encontrar, além dos próprios enunciados, a intenção do sujeito falante, sua atividade consciente, o que ele quis dizer, ou ainda o jogo inconsciente que emergiu involuntariamente do que disse ou da quase imperceptível fratura de suas palavras manifestas; de qualquer forma, trata-se de reconstituir um outro discurso, de descobrir a palavra muda, murmurante, inesgotável, que anima do interior a voz que escutamos de, reestabelecer o texto miúdo e invisível que percorre o interstício das linhas escritas e, às vezes, as desarruma.

Maingueneau (2004), no capítulo intitulado "Ethos", antes mesmo de expor sua definição, retoma Barthes que afirmara como característica essencial do ethos os traços de caráter apresentado pelo orador, a fim de se mostrar para o auditório, de forma as causar boa impressão, pouco importando a sinceridade ou não no que foi demonstrado. Para esclarecer o conceito, Maingueneau (2004, p. 99) prossegue:

O ethos implica (...) uma disciplina do corpo apreendido por intermédio de um comportamento global. (...) O poder de persuasão de um discurso consiste em parte em levar o leitor a se identificar com a movimentação de um corpo investido de valores socialmente especificados. A qualidade do ethos remete (...) à imagem desse "fiador" que, por meio de sua fala, confere a si próprio uma identidade compatível com o mundo que ele deverá construir em seu enunciado.

Para Lonardoni (2004), abordar o conceito de ethos no discurso é tratar de um aspecto próprio a esse discurso, pois, conforme afirma Maingueneau (2004), toda fala 
procede de um enunciador encarnado. Em outras palavras, qualquer que seja o enunciado (escrito ou falado) ele traz a voz de um sujeito que se situa espacial e temporalmente. Continua Lonardoni (2004:120):

... o ethos é um fenômeno ocorrido com o desdobramento da retórica tradicional e, através da enunciação, revela-se a personalidade de quem fala. (...) a eficácia do ethos está relacionada ao fato que ele faz parte da (...) enunciação, mas sua existência não vem ou não está explicitada no enunciado.

Silva (2007) explica o conceito de ethos como sendo uma estrutura que se revela pela enunciação e que faz emergir a personalidade do enunciador. Acredita a estudiosa que o estilo, por meio do qual um sujeito se exprime, é um aspecto discursivo da identidade e um componente desse ethos. Enfim, os vários autores mencionados apresentam um posicionamento sobre o ethos, em conformidade com o explorado por Maingueneau (2004).

\subsection{A Sociolingüística Interacional e alguns aspectos relativos aos Gêneros}

No Brasil, muitos trabalhos alicerçados em estudos da Sociolingüística Interacional tiveram por tema o conteúdo de fitas do projeto NURC, em que ocorrem situações de fala em sala de aula, em conversa corriqueira, entre diversas outras situações. Entretanto, há que se frisar que a Sociolingüística Interacional não prevê apenas a interação face a face, conforme Souza (2003, p. 59) aponta:

As interações referem-se não apenas àquelas que acontecem face a face, os processos interativos também decorrem de uma compreensão ativa em que o leitor aceita, reformula, contrapõe, complementa as informações do texto, conforme seus conhecimentos e experiências.

Se não há uma relação direta, face a face, por exemplo, entre autor (es) de textos da revista e o leitor, obviamente a interação não deixa de existir, até porque não há texto neutro, independentemente de ser oral ou escrito, que não tenha um leitor como alvo.

A um trabalho teórico sob enfoque central da $\mathrm{AD}$ e que, de dada maneira, aborda questões da Sociolingüística Interacional, faz-se necessário refletir, também, sobre o gênero 
no qual se insere o(s) texto(s) analisado(s). Desta feita, mais uma vez podemos verificar o imbricamento dessas disciplinas com os conceitos de Bakhtin, no caso específico, as que se referem ao que este definiu como gênero do discurso.

Como comprovação dessa relação óbvia, basta ter em mente que os falantes utilizam a língua, por meio de alguns gêneros, para dada situação de uma esfera de atividade social. Silva, compactuando com essa crença, de que o uso de distintos gêneros ocorre, de acordo com situações dadas e afirma (2007, p. 123):

... quando produzimos diferentes tipos de discurso, apresentamos tipos de diálogos distintos uns dos outros; quando conversamos com alguém ou quando escrevemos um livro (...) estamos a utilizar níveis diferentes de diálogos. Da mesma forma, dentro do espaço do jornal, há discursos que se distinguem uns dos outros, conforme sejam notícias, reportagens, entrevistas, entre outros.

O enfoque nos gêneros não pode deixar de permear um trabalho, cujo foco é o texto jornalístico, de forma geral. Na mídia impressa, encontramos um variado número de gêneros. No que tange à imprensa, Grilo $(2004$, p. 64) explica:

Nos gêneros de informação da imprensa, o jornalista assume um papel exterior à realização do fato, que "preexiste" à sua ação, e exime-se da interpretação desta, papel atribuído aos gêneros opinativos (editorial, (...) artigos assinados). Com isso, o sujeito enunciador apresenta-se mais escondido que no discurso científico, o que se dá por meio do apagamento das condições de enunciação do discurso jornalístico (...) isso não quer dizer que não haja subjetividade no discurso jornalístico, mas que a natureza da produção de notícias e reportagens contribui para a construção de um discurso que se quer centrado no referente, elaborando estratégia de apagamento do sujeito da na natureza necessariamente significativa ou atribuidora de sentido de todo ato de linguagem.

As marcas peculiares a cada um desses gêneros e também a maneira de explorar um certo assunto pode revelar muito sobre esse produtor do texto e isso é bastante relevante para nossa pesquisa. Mesmo não sendo o gênero nosso enfoque aqui, mas indispensável no momento de procedermos às análises, urge que nos reportemos, novamente, a um nome de suma importância, Bakhtin. 
Primeiramente, o estudioso divide-os em gêneros do discurso primários, aqueles constituídos, próprios da vida cotidiana; e gêneros do discurso secundários, são gêneros mais complexos, elaborados e desenvolvidos em situação de troca cultural, geralmente são textos escritos, enquanto prioritariamente os gêneros do discurso primários são orais. Há, entretanto, relação imediata entre um e outro gênero do discurso.

A utilização de um ou de outro gênero implica uma série de fatores. Brandão (2004) avalia que cada um dos gêneros, em cada uma das áreas de comunicação verbal, apresenta sua concepção padrão do destinatário que determina como gênero. Dependendo do gênero, é possível verificar uma estrutura esquemática mais ou menos comum, muitas vezes préestabelecida. Ou seja, fala-se, então, em um tipo de regularidade, assim como apregoado também por Foucault, no que tange a sua visão sobre o discurso. Todavia isso não quer dizer que determinados gêneros não apresentem alguns desvios, completamente tolerados em certas situações comunicativas.

Como para nosso estudo o que nos interessa mais são os gêneros relativos ao discurso jornalístico, acreditamos também que, embora haja predomínio de uso dos gêneros secundários em relação aos primários, aqueles são, de fato, de alguma maneira, influenciados por estes. Acerca disso, Ponte (2004, p. 16) compreende que:

Há inter-relações entre géneros primários e secundários: se os discursos secundários vão absorver e assimilar conteúdos dos discursos primários, estes, (...) alteram-se e assumem um caráter especial quando entram em géneros secundários, perdem a sua relação imediacta com a realidade concreta (...) no discurso jornalístico (...) vemos circular com alguma frequência géneros primários como provérbios ou máximas, textos relativamente estáveis e de um autor colectivo, desinseridos do seu contexto e transferidos para novos contextos (...)

Bakhtin (2004), ainda no que se refere à teoria dos gêneros, mais precisamente ligados ao jornalismo, ressalta a questão do estilo, orientado para a variação que permite diferenciar como distintos discursos dizem respeito ao mesmo. Para isso, dentro do gênero de informação da imprensa, há realizações diversas como, por exemplo a notícia breve, a reportagem, o editorial, entre outros. Sousa (2003) fala que a tipologia dos gêneros jornalísticos opõe, de forma clara, os textos que levam o leitor a conhecer certos fatos, notícias e os textos que levam ao leitor idéias, os comentários. Para o autor, essa divisão tem raiz nos Estados Unidos, onde o jornalismo se desenvolveu desde cedo, com base na 
distinção entre story e comment. Tomando-se por base essa distinção de gêneros, a história, o acontecimento seria propriamente o fato ocorrido, já no que concerne ao comentário, Foucault (1997) considera este como um dos procedimentos internos de controle do discurso. O comentário seria um dispositivo discursivo para dominar o próprio discurso, reduzindo o que este tem de acontecimento e acaso.

Ainda relativo ao gênero, mas com um outro enfoque, Ponte (2004, p. 17) invoca Bakhtin (1981) que conclui seu entendimento sobre o estilo:

O estilo de um discurso está inseparavelmente ligado a unidades temáticas particulares e sobretudo a unidades particulares de composição. Construções particulares do todo, tipos da sua constituição, tipos de relação entre o orador e os outros participantes (leitores, ouvintes, parceiros, as suas falas (...) Os estilos caracterizam-se por poderem circular de um género para outro, numa transferência que (...) não só altera o modo como um estilo aparece nas condições de um género que não lhe é natural, como também viola ou renova o próprio género de origem.

Apesar de termos procedido apenas a um recorte da teoria dos gêneros neste momento de nosso estudo, tais conceitos serão recorrentes, ao longo de outros itens e capítulos.

Quanto à Sociolingüística Interacional, esta nos dará subsídios para analisarmos textos retirados de algumas revistas de atualidades que circulavam em Portugal e no Brasil na década de 60 do século XX, na medida em que nos interessa entender também os mecanismos de interação nos textos em questão. A área teórica citada visa a estudar o comportamento verbal no contexto da interação, nas relações sociais, em que os indivíduos mostram sua existência, inseridos naquela determinada situação. Assim, enfatiza-se a especificidade sócio-cultural do fenômeno da comunicação. Lima-Fernandez (2005, p. 150) se coloca acerca da relação entre aspectos sócio-culturais e a expressão lingüística, nos seguintes termos:

Tendo em vista que o aspecto cultural congrega interferências diversas, (...) a expressão lingüística que se inicia de modo restrito em um segmento social específico pode ser incorporada (ou não) pela sociedade como um todo. Sua assimilação por outros segmentos constitui-se, para o atento estudioso da língua, caso de 
fortalecimento e projeção social que deve ser observado mais de perto.

Fernandes (2001) afirma que o discurso na perspectiva sócio-interacional toma a língua, materializada em forma de texto, de maneira que em todas as instâncias, o discurso é o objeto central, por excelência.

Verificando a interação no texto escrito, entendemos como imprescindível ter claras as diferenças que se referem às marcas próprias de uma linguagem falada e de uma linguagem escrita. Tais distinções comumente são vistas da seguinte forma:

A fala não é planejada, é fragmentária, por vezes tida como incompleta, pouco elaborada, com predomínio de frases curtas, simples ou coordenadas e pouco uso de passivas. Já a escrita é vista como planejada, não fragmentária, completa, elaborada, com predomínio de frases complexas, subordinação abundante e emprego freqüente de passivas.

Apesar disso, sabemos que há gradações e tanto dentro de um texto oral como de um texto escrito, ou seja, nas duas manifestações, oral e escrita, há textos mais ou menos formais e elaborados. Entretanto, levando-se em conta as esperadas distinções, parece importante a observação de Koch (2000, p. 68):

Ocorre, porém, que estas diferenças nem sempre distinguem as duas modalidades, mesmo porque existe uma escrita informal que se aproxima da fala e uma fala que se aproxima da escrita, dependendo do tipo de situação comunicativa. Assim, o que se pode dizer é que a escrita formal e a fala informal constituem os pólos opostos de um contínuo, ao longo do qual se situam os diversos tipos de interação verbal.

Assim sendo, nossas interpretações dar-se-ão de maneira a procurar certa aproximação do que está presente nos textos estudados, sob a ótica das teorias referidas. Conforme afirma Lima-Fernandez (2005, p. 137):

Para sociolingüistas, a proliferação de formas para uma (aparente) função única basta como evidência de que fatores sociais condicionam os lingüísticos. 


\subsection{Os possíveis laços entre a Análise do Discurso e as teorias lingüísticas que enfatizam a interação}

São muitos os que vêem claras possibilidades de articular conceitos e estudos da AD e da Sociolingüística Interacional, de tal modo que certos pesquisadores já alicerçaram seus trabalhos tendo as duas disciplinas por condutoras.

Fernandes (1999) já percorreu tal trilha, no desenvolvimento de sua dissertação de mestrado. Ao mencionar a referida articulação, não consegue deixar de levantar questões e, em seguida, procura respondê-las, com o intuito maior de não fugir ao que inicialmente se propôs, explorar tanto a AD como a Sociolingüística Interacional. Dessa forma, Fernandes (1999, p. 92):

... em que ponto uma disciplina encontra-se com outra(s), e onde se separa (se é que se separa)? Afinal, quais são os limites de uma disciplina (será que tem limites)?

Sobre esta questão, Foucault (1970:31), ao discutir os procedimentos de controle e de limitação do discurso, fala sobre o discurso da disciplina (...) ousamos dizer que não nos limitamos aos domínios de uma disciplina da lingüística, até mesmo por não os conhecer, ou melhor, por não sabermos se existem; afinal caminhamos por domínios da lingüística, da psicologia social, da antropologia, da sociologia.

(...) ao entrarmos em um campo interdisciplinar, colocamos em contato diferentes princípios de controle do discurso, o que implica romper com os limites disciplinares, romper com o controle de uma disciplina específica. (...) a Análise do Discurso e a Sociolinguiística Interacional (...) se ocupam (...) da sobreposição de voz nas relações de poder, e consideram que o discurso do sujeito revela seus status e sua visão de mundo (...).

O mesmo autor, Fernandes, já em sua tese de doutorado, (2001) novamente articula perspectivas sócio-interacionais com a $\mathrm{AD}$, mais uma vez enfatizando a questão da interdisciplinaridade, presente em vários estudos e envolvendo diferentes áreas do conhecimento. Para o autor, a AD, centrada na interação social, é foco da Lingüística com distintas abordagens disciplinares, logo, distintas perspectivas são verificadas no que se refere ao tratamento dado ao objeto central de certa análise.

Um outro ponto de intersecção entre a AD e a Sociolingüística Interacional pode ser verificado, ao nos voltarmos para Maingueneau, que, em seu livro Análise de Textos de 
Comunicação, no segundo capítulo, intitulado "As leis do discurso", faz referência à chamada preservação da face. Esse conceito abarca a questão da polidez e tais fenômenos de polidez integram a teoria chamada "das faces", estudada por P. Brown e S. Levinson, os quais se inspiraram fortemente no trabalho do sociólogo canadense E. Goffman.

A preservação da face é um aspecto que entendemos como relevante para nossa pesquisa. Em fragmentos de texto é possível verificar, de forma explícita ou implícita, se a face de quem lê está ou não sendo ameaçada, bem como se a face de um indivíduo ou de uma instituição pode ter sua "face" ameaçada, pela maneira com que foi abordado em uma reportagem, por exemplo. Para Maingueneau (2004, p. 37):

Como a comunicação verbal é também uma relação social, ela se submete como tal às regras que costumamos chamar de polidez. Transgredir uma lei do discurso (falar fora do assunto, ser hermético, não dar as informações solicitadas etc.) é se expor a ser chamado de "mal-educado". O simples fato de dirigir a palavra a alguém, de monopolizar sua atenção já é uma intrusão no espaço, um ato potencialmente agressivo. Esses fenômenos de polidez estão integrados na teoria denominada "das faces" (...)

Nem sempre a questão da preservação ou não da face é facilmente verificada em textos veiculados nesses periódicos. No caso de cartas dirigidas à redação de uma revista, Lonardoni (2004) afirma haver ausência de prestígio do leitor em relação à linha editorial de jornais/revistas, o que é possível de se verificar no ato da leitura das cartas publicadas. Normalmente, são impressos apenas trechos, paráfrases e sínteses dos textos enviados pelos leitores. Dessa forma, o que predomina é o ethos da própria revista. Tal fato não pode ser entendido como o que ocorre em todas as revistas e da mesma forma.

Concluímos, assim, que o que diz respeito à preservação de face, no caso específico das revistas, é um fator determinante no critério de quais cartas serão publicadas, ou melhor, que parte das cartas será exposta. A referência às cartas destinadas à redação se deu por termos procedido à leitura de trabalhos, cujo enfoque era esse tipo de relação em que pode ser verificável a noção de polidez, de preservação de face, o que não é o nosso alvo.

Ao levarmos em conta a interação, de uma forma ampla, num primeiro momento, tanto a que envolve uma relação face a face, como aquela em que se presume um evento comunicativo, independente de estarem os interactantes em situação de conversa, por exemplo, parece-nos pertinente retomar Preti (1994), ao afirmar o que é relevante levar em 
conta, no ato da interação. Assevera o autor que é imprescindível, no que se refere ao falante, refletir acerca de fatores que determinam/influenciam a fala de um indivíduo, quais sejam: idade, raça, posição social, grau de escolaridade, local em que reside na comunidade. Se há clara influência de variados fatores na maneira com que um indivíduo se expressa, oralmente ou não, distinções há também quanto à opção por um gênero. Dessa forma, a afirmação a seguir, de Bakhtin (2003, p. 302), apesar de focar na questão do gênero do discurso, possibilita-nos estabelecer uma correspondência com o que foi dito por Preti, anteriormente.

\begin{abstract}
Nas condições de um regime de classes e particularmente de castas, observa-se uma excepcional diferenciação dos gêneros do discurso e dos respectivos estilos em função do título, da categoria, da patente, do peso da fortuna e do peso social, da idade do destinatário e da respectiva posição do próprio falante (ou de quem escreve).
\end{abstract}

Para Preti, em relação aos fatores pertinentes à situação de comunicação é importante considerar o ambiente, o tema, o estado emocional do falante (este possível de se detectar em situação em que não ocorre a interação face a face. Exemplo de uma carta em que o autor expõe seu amor/ódio, apreensão/ansiedade). Por outro lado, há que se considerar como relevante também a distinção que pode ocorrer entre os registros.

Estes podem se distinguir quanto ao campo do discurso (área de operação da atividade lingüística, assunto), o modo do discurso (fala e escrita), o estilo do discurso (coloquial ou polido). Em todos os gêneros do discurso, a natureza e o objetivo da interação são decisivos na seleção do registro que será utilizado.

Finalizamos o capítulo com a crença já apresentada anteriormente, quanto aos encaminhamentos teóricos que não só se mostram passíveis de conjunção, tendo em vista o corpus, mais à frente analisado, como nos parece importante voltar a ressaltar nosso entendimento da AD como "carro chefe" que nos guiou durante todo o percurso. Assim, comungamos da visão acerca da AD em Orlandi (1997, p. 184) que pondera:

A análise de discurso é enfim uma relação com a linguagem: relação em que se mantém a distinção forma/conteúdo, mas antes se pensa a questão da sua materialidade que é lingüística e histórica e na qual se pode pensar o silêncio em sua importância 
fundamental. E se assim é, vamos deixar nesse ponto, que os sentidos da reflexão que ela nos propõe façam seu percurso, acolham o tempo de sua previdência, e se devolvam o seu silêncio. Porque é nele que estão os outros sentidos. 


\section{Capítulo 4 - Métodos e Procedimentos}

A consecução deste trabalho ocorreu, desde o início, no segundo semestre de 2004, numa contínua busca e delimitação do corpus, bem como de teorias apropriadas que nos possibilitaram proceder às análises. Até o fim do primeiro semestre de 2005, sentindo-nos convencidas de que a Análise de Discurso de linha francesa e também as teorias de Bakhtin servir-nos-iam de pilastras teóricas e, ainda que tivéssemos nos decidido por um estudo com revistas de variedades no Brasil e em Portugal, assim como um determinado período, não tínhamos claro o número de textos, bem como a área temática como cultura, política Ciência, comportamento a serem trabalhados.

Em viagem a Portugal em 2005, durante a coleta de material, após conhecermos várias revistas locais do gênero variedades, estávamos decididas a traçar um paralelo entre publicações brasileiras e portuguesas. Assim, estas deveriam ser de uma mesma época. Por já termos escolhido analisar revistas que circulavam durante o período militar brasileiro, achamos que seria importante fazer um recorte no tempo, a fim de explorarmos, em ambos países, esse período de governos autoritários.

Dessa forma, fizemos uma primeira delimitação mais objetiva: que as publicações fossem de 1964 a 1973. Em seguida, por entendermos a década de 60 como tão singular, delimitamos mais e intencionamos verificar as publicações restritas aos anos 1964 e 1969. $\mathrm{O}$ passo seguinte foi pensar quais revistas trabalhar. Elegemos duas brasileiras e duas portuguesas. Como ainda não tínhamos decidido quais seriam essas publicações, conseguimos um bom número de exemplares do período de 1964 a 1969. Das brasileiras, tínhamos as revistas Realidade, Visão, Fatos e Fotos e O Cruzeiro. As portuguesas eram Vida Mundial, Século Ilustrado, Observador e Flama. Na seqüência, partimos para mais uma delimitação: analisar textos com temática política nacional ou internacional.

Com o grande corpus, partimos para algumas análises prévias e continuamos com leituras teóricas importantíssimas, algumas de forte confluência, no que se refere a um estudo voltado para o discurso das mídias, a sempre presente área teórica Análise do Discurso, estudos de História do Brasil e de Portugal, entre outras significativas contribuições, todas referências bibliográficas que se coadunavam. Nesse caminho, preparamo-nos para nosso exame de qualificação. 
A afirmação comum aos professores da banca, bem como já alertava a orientadora Profa. Dra. Irenilde, é de que seria necessário fazer um recorte mais drástico, a fim de que pudéssemos produzir análises aprofundadas. Dessa maneira, no início de 2007, tínhamos o recorte claro e preciso para darmos "corpo" ao nosso projeto. Decidimos por duas revistas, uma brasileira e uma portuguesa do ano de 1968.

Como já conhecíamos outras publicações dos dois países, não foi difícil perceber algumas relações entre duas revistas e por esses aspectos comuns optamos pela brasileira $\mathrm{O}$ Cruzeiro e pela portuguesa Flama.

Com o objetivo de melhor pesquisar as publicações portuguesas, bem como o contexto histórico da época e as marcas culturais passadas e presentes, solicitamos uma bolsa de estudo para Portugal. Foi-nos concedida a bolsa e partimos em setembro de 2007, onde permanecemos até janeiro deste ano e fomos co-orientadas pela Profa. Dra. Olívia Maria Ferreira Gonçalves Figueiredo, da Universidade do Porto.

Foi um período extremamente fértil, pois além dessa nossa recolha de corpus, das leituras teóricas que prosseguíamos, das análises que começavam a se delinear mais concretamente, ainda pudemos participar de congressos e seminários na área de Lingüística, além de ter um contato mais real com a cultura local.

Em virtude de nossa estada, conhecemos, ainda, muitos trabalhos acadêmicos, teses e livros de autores que também trabalharam a mídia impressa no período Salazar, bem como pós o 25 de abril. Todo esse cabedal nos foi fonte de conhecimento e de condução para um olhar mais atento, no que diz respeito às publicações portuguesas, quer pela época, quer pela empresa detentora da revista escolhida, quer pelo público alvo, entre os importantes fatores.

Após meses de procura das edições que viriam a compor nossa tese, as três publicações de 1968, de ambos os semestres, nosso trabalho começava a tomar uma forma bem mais definida, já que havíamos seguido a trilha da seleção, da ordenação, da leitura, da releitura, da interpretação, da montagem, da desmontagem de um ano. Tudo isso nos foi fundamental para conseguirmos chegar às análises. 
As revistas selecionadas são vistas, genericamente, como do estilo "atualidades". Tanto a brasileira "O Cruzeiro" como a portuguesa "Flama" eram de circulação semanal. Se a revista brasileira, em alguns momentos e números pode ter ficado mais próxima do que alguns entendem como uma revista de amenidades, em virtude da predominância de assuntos menos sérios, contundentes socialmente, esse pareceu ser mesmo o perfil da Flama, de uma forma geral.

Em relação ao que vem a ser uma revista de atualidades ou de amenidades, entendemos a primeira como uma edição mais voltada para questões sociopolíticas nacionais e internacionais atuais, ao passo que as revistas de amenidades abordam temas menos politizados ou os abordam sob um viés mais superficial, além de ter por enfoque notícias de pessoas de grande visibilidade na sociedade.

Nosso ponto de vista sobre a publicação portuguesa, o de enxergá-la como uma revista mais de amenidades, construiu-se com base em vários outros números, de diversos anos, graças às análises prévias iniciadas em 2005, em nossa primeira incursão pelos alfarrabistas $^{5}$ em Lisboa, além das leituras dessa e de outras revistas da época, na Biblioteca Nacional, também em Lisboa. No que diz respeito ao público-alvo, tanto a revista brasileira como a portuguesa, apresentavam apelos para a família, instituição ainda não tão em crise na época, para a mulher, sem deixar o homem de lado. Como critério de escolha, além do ano de 1968, previamente justificado, começamos a analisar as três revistas de Portugal e as três do Brasil.

Após esse segundo critério de delimitação, escolhemos iniciar nosso outro recorte pelas revistas portuguesas, aproveitando o momento de estágio no exterior. Assim, começamos nossa incursão, primeiramente nas bibliotecas, verificando as revistas, muitas das quais estão encadernadas por um período de alguns meses, ou seja, como eram semanais, estas estavam agrupadas, geralmente, num total de doze exemplares.

Como não vimos publicações que se mostrassem, por algum motivo, extremamente particularizadas, diferenciadas, distintas das demais, ao longo do ano de 1968, seguimos à procura das revistas em alfarrabistas e feiras de antigüidade. O trabalho foi difícil, de garimpagem, pois muitas vezes encontrávamos a Flama, mas não de 1968 ou, em alguns

\footnotetext{
${ }^{5}$ Mantivemos a palavra alfarrabista, locais explorados para nossa coleta para o corpus. A designação equivalente no Brasil é sebo.
} 
casos, em mau estado de conservação, o que, por vezes, impediria não só um manuseio, mas também uma devida leitura da revista, por não estar inteira, por exemplo.

Aos poucos, fomos conseguindo exemplares e pensamos num outro pré-requisito: que as mesmas não fossem todas do primeiro ou do segundo semestre. Queríamos revistas dos dois semestres. Chegamos, finalmente às publicações que foram analisadas: uma de abril, uma de agosto e outra de setembro de 1968.

De posse das revistas, voltamos à Biblioteca Nacional, para nos certificarmos de que, de fato, a seleção feita poderia corresponder a um perfil da publicação, de forma geral, do ano em questão. Concluímos que os critérios eram válidos para seguirmos com nosso trabalho e passarmos, efetivamente, para as leituras mais apuradas dos exemplares.

Apesar da grande crise pela qual passava Portugal, em virtude da longa guerra na África, no ano de 1968 apenas três exemplares da revista Flama trouxeram na capa tal assunto e exploraram o tema de uma maneira um pouco superficial. O motivo mais provável para a pouca exploração da guerra, nos textos, tenha se dado, porque o regime de governo não abria espaço para críticas ou conhecimento mais detalhado dos bastidores do interminável conflito. Assim, os exemplares escolhidos, como a maioria dos números de 1968, não exploraram o tema.

As questões de política externa eram mais exploradas do que a política interna, de forma geral. Houve números com capas relativas às eleições nos Estados Unidos, antes e depois da vitória de Nixon, mas apenas dois números sobre Marcello Caetano, então dirigente máximo do país.

Quanto à publicação brasileira, tínhamos, de antemão, a convicção de que seria menos difícil conseguir os exemplares, por dois motivos: primeiro por serem revistas brasileiras e o acesso não ser tão limitado, comparando-se com as publicações portuguesas; por outro lado, sabíamos que as revistas, ao menos alguns números delas, estavam disponíveis por meio eletrônico. Dessa forma, passamos a buscar exemplares correspondentes aos meses selecionados para as revistas portuguesas, sem, contudo, deixarmos de verificar, também, se no ano de 1968 houve algum número que se distinguiu sobremaneira, em relação aos demais. O que também nos foi possível, após buscarmos locais em que as mesmas estavam arquivadas, a saber, bibliotecas, colecionadores, casas 
especializadas em revistas antigas e também no Arquivo do Estado, situado na zona norte da capital. Muitos dos endereços foram conseguidos pela internet.

De posse dos seis números, mediante a seleção mencionada, tínhamos, então, como finalmente seguir nosso trabalho de leitura, releitura, interpretação, montagem e remontagem do que foi o ano de 1968, ao menos aos olhos das revistas em questão.

\subsection{A Flama e a Cruzeiro}

... os seus conteúdos estabelecem, precisamente, linhas às quais hão-de dar continuidade ininterruptas ao longo de 43 anos, não foi difícil reconhecer na sua história enormes descontinuidades, em termos dos critérios editoriais seguidos.

Diogo Ramada Curto

\subsubsection{A Flama}

A Flama foi uma das mais marcantes revistas em circulação em Portugal no século passado, tendo tido maior repercussão, sobretudo na segunda metade dos anos 60 e início dos 70, apesar de ter a significativa concorrência de outras publicações, como a "O Século Ilustrado" e "Vida Mundial", sem falar na "Seara Nova". Mas há a crença de que foi mesmo a Flama, de certa forma, a responsável por introduzir nos hábitos de leitura o gosto pelas newmagazines, um sucesso já de anos em outros países.

A revista foi fundada em fevereiro de 1937, ainda no formato de jornal quinzenal, de propriedade da instituição Juventude Escolar Católica. Naquele momento apresentava uma característica de jornal ilustrado de atualidades. Logo no número de estréia, o então diretor de redação explicou a escolha do nome, dizendo ser o jornal legenda e propaganda, já que Flama quer dizer luz e calor, o que era, segundo o diretor, a missão precípua daquela publicação justamente a de "espalhar luz e calor à sua volta".

A composição inicial do jornal contava apenas com oito páginas em preto e branco, no primeiro ano. As pessoas podiam adquirir o jornal avulso, nas bancas, ou fazer uma assinatura e chegou mesmo a poder ser conseguida nas colônias portuguesas, assim como em outros países.

\footnotetext{
${ }^{6}$ Para reproduzir trechos das duas revistas, optamos por usar as aspas duplas e o itálico, com o objetivo de destacar as passagens analisadas.
} 
Entretanto, essa aventura de jovens estudantes católicos teve seu fim em janeiro de 1942. Após um hiato de dois anos, a publicação voltou, mas sob forma de revista, tendo sua reestréia em maio de 1944. Apesar de um novo formato, continuava de propriedade da Juventude Escolar Católica, contando com o apoio de um cardeal de Lisboa. Os cargos de diretor e de editor estavam sob a tutela do frei João Diogo Crespo, que, embora não tivesse seu nome na ficha técnica da revista, era, de fato, seu real "diretor editorial", o qual assinava uma coluna de opinião sob o título: “À Margem”.

Instalados em novo endereço, foi lançado o primeiro exemplar da revista Flama, que passou a ter dezesseis páginas, contando com o recurso de utilização de muitas fotografias. É no segundo número da Flama, em 28/05/1944, que o diretor apresentaria o projeto da revista, até então mensal:

Flama tem entre os seus fins o de promover o progresso das letras e o do amor pela Ciência entre a gente môça. Podíamos ocultar um pouco a nossa qualidade de católicos activos e muito aumentaria o nosso público, mas a Flama não quer equívocos e tem amor a situações claras.

A revista mantinha a estrutura ideológica sob a égide do catolicismo, porém ia além da mensagem cristã, tendo espaço para o esporte, o teatro, o cinema. Ademais, logo nesse segundo número, incorporou a tradição de apresentar uma entrevista com pessoas de vulto, no cenário do mundo dos espetáculos. Essa opção por entrevistar indivíduos de muita visibilidade repercutiu positivamente, em especial nos anos 60, momento em que essas celebridades quase sempre eram as capas da revista.

Em seu terceiro número, houve espaço para outro gênero jornalístico, a reportagem, contando com a forte contribuição da fotografia. A revista foi ganhando cada vez mais visibilidade e leitores e em 1948 já era a revista mais assinada em Portugal, com venda de 17 mil exemplares por mês. Nesse período, a revista sofreu algumas alterações, em especial no que diz respeito à parte gráfica, mas continuando a dar relevo às fotografias.

No mês de novembro de 1948, a Flama passou a ser de propriedade da União Gráfica. A revista não saiu em janeiro de 1949 e voltou a circular em fevereiro do mesmo ano, como se nada tivesse ocorrido. A justificativa se deu no número de março, quando o

\footnotetext{
${ }^{7}$ Citação retirada do site
} 
frei Diogo Crespo explicou as transformações pelas quais passou a revista, tudo em virtude de uma dívida de 62 mil contos. De acordo com o explicado pelo frei, a nova remodelação deu-se graças à intervenção do Monsenhor Avelino Gonçalves, diretor da União Gráfica, que conseguiu a fusão de três revistas, a Renascença, a Flama, e a Papagaio. Assim, a Flama pôde contar com seções que já existiam nas outras. Passou a publicar uma seção infantil, a Papagaio, com histórias e jogos para crianças, além de apresentar também a programação da Rádio Renascença. A partir daí, nasceram outras seções, como a relacionada à crítica de cinema e à moda feminina, por exemplo. ${ }^{8}$

A União Gráfica investiu mais ainda em outra sede, além de contratar mais jornalistas, já que alterou sua periodicidade, sendo publicada semanalmente. O diretor da União Gráfica afirmava que a revista não se destinava à determinada categoria de pessoas, mas aos de fé e pessoas de bom gosto, "que preferem o belo ao pornográfico, o elevado ao banal e acham mais nobres e humanas as coisas da vida quando através delas perpassa um sopro de espiritualidade". Afirmava, ainda, ser a publicação isenta de caráter oficial ou oficioso guiado pela religião ou pela política.

No quinto aniversário da revista, a direção festejava mais de meio milhão de exemplares que chegavam a todos os cantos do país e atingia também outras nações. A revista ganhou mais leitores no decorrer da década de 50 e no início dos anos 60 contratou, sob orientação de um novo diretor, jovens jornalistas que, anos mais tarde ocupariam lugar de destaque na imprensa portuguesa.

Curto, em relação à publicação tão conhecida afirmou (2006, p. 525):

... na Flama, (...) é de referir o aparecimento de uma secção intitulada "A semana pela imagem", na qual se fotografavam manifestações protocolares onde participavam membros do aparelho de Estado e batalhões de militares embarcando para as colônias. O progressivo acento destas fotos afirma-se como claro prenúncio da guerra colonial e, de certo modo, como legitimação dessa intervenção. O que une ambas as secções é o ipso da imagem prevalecer sobre o texto e o modelo de legendagem se centrar na descrição dos títulos, postos ou grande parentesco dos indivíduos fotografados (...) A partir de 1960, os cenários bélicos são

\footnotetext{
${ }^{8}$ Vale ressaltar que o grande público da revista era feminino. Aliás, de acordo com recente pesquisa de 2007, $70 \%$ do público feminino português continua preferindo ler revistas. Dados obtidos em virtude da I Conferência PNL (Plano Nacional de Leitura), no dia 22/10/2007, em comemoração ao dia internacional da biblioteca escolar.
} 
paulatinamente ofuscados nas reportagens, contrastando com o efectivo avanço do movimento armado sobre as antigas colônias.

Em 1964, a direção da Flama foi entregue a António Reis, um homem com estritas relações com a hierarquia da Igreja. No fim dos anos 60, a revista foi constituída por uma equipe de reconhecida importância, por contar com alguns dos melhores jornalistas do país. Apesar disso, segundo o divulgado mais tarde, rara era a edição que não sofria com a tesoura da censura.

António Reis, em entrevistas mais recentes, afirmou que a revista era uma voz independente, que não se curvou às pressões de todos os lados. Afirmou ainda que tinham de ter sempre reportagens e notícias alternativas, devido aos grandes cortes que a censura praticou na Flama.

Mesmo com tantos obstáculos, a revista atingiu seu apogeu entre 1967 e 1971, momento em que teve suas páginas ampliadas para uma média de sessenta e oito, sendo cerca de metade ocupada por publicidade. Segundo a crença de alguns, a receita de sucesso residia na combinação de assuntos políticos importantes, aliados ao enfoque nas pessoas de relevância da sociedade ou do mundo do espetáculo, o que se dava em páginas bastante ilustradas de fotografias.

Após o afastamento de Salazar, a Flama, aos poucos, aproveitando o relativo afrouxamento do período marcellista, introduziu em suas capas pessoas, cujo perfil constituía em temas de polêmica abordagem, para o momento de ebulição política ocidental. Foi o caso de trazerem na capa Martin Luther King.

Em 1972, a revista voltou a mudar de mãos e passou a ser propriedade da Sociedade Editorial Flama. Ainda conforme seu último diretor, António Reis, o que levou a revista à difícil situação financeira foi o próprio poder capitalista. Como apontado em algumas fontes, o controle da imprensa pelo poder econômico era comum na época de Marcello Caetano. Muitos jornais e revistas que se encontravam em crise se viam sob o resguardo econômico do Banco Nacional Ultramarino ou da Caixa Geral de Depósitos, de acordo com a orientação do governo. O objetivo era o controle econômico da imprensa, em especial daquela que mantinha características de independência. É então nesse contexto de dificuldade financeira que a Flama encerra suas atividades em setembro de 1976. 
Curto (2006), a partir de um estudo mais abrangente da revista, com base nos números editados entre 1944 e 1976, acredita que a Flama tomou sentidos contraditórios, quer optando por uma estratégia mais popularizante, quer restrita, tendo como alvo um público mais informado.

Para Santos (2001), a trajetória do jornalismo em Portugal não pode ser separada da própria história do Jornalismo e da sociedade portuguesa dos últimos séculos. Assim, acredita em inegáveis influências (2001, p. 11):

A presença da censura política e religiosa com o exercício do exame prévio, o encerramento de jornais e a condenação dos seus responsáveis a pesadas penas, a quase ausência de um "espaço público de discussão" (...) as elevadas taxas de analfabetismo e os baixos índices de leitura de jornais, o provincianismo como ideologia ou a proibição ou criação de dificuldades à constituição de cursos profissionais nesta área nos tempos mais recentes são apenas alguns dos elementos de uma rede complexa de interacções que vão afetar os modos como, em Portugal, o jornal tem intervindo na escolha e tratamento de acontecimentos do país e do mundo.

\subsubsection{O Cruzeiro}

(...) na presidência de o Cruzeiro, Chateaubriand começava a dar uma nova cara a seus jornais e revistas.(...) começam a aparecer (...) personagens (...) como Manuel Bandeira, (...) Graça Aranha (...) David Nasser (...) Millôr Fernandes, Carlos Castello Branco e Frederico Chateaubriand (...) um dos grandes responsáveis pela transformação de O Cruzeiro em uma das mais importantes revista do Brasil(...)

Fernando Morais

A idealização do projeto da revista "O Cruzeiro" iniciou-se com um português, Carlos Malheiros Dias, que não deu continuidade à empreitada, por falta de recursos. Assis Chateaubriand interessou-se pelo projeto, mas também não tinha como arcar com os custos. Chateaubriand era uma figura singular, de grande projeção, bem nascido e com bons contatos. Apesar de ter passado por problemas pessoais que o impediram de se alfabetizar antes dos doze anos, aos dezoito já trabalhava em um pequeno jornal. Poucos anos depois, 
passou a integrar outros jornais mais importantes, até chegar ao seu objetivo inicial e ser proprietário de um, o que ocorreu em 1923. E, assim, principiou-se o que viria a ser o império das comunicações do embaixador Chateaubriand. Como pessoa bem relacionada, por intermédio de Getúlio Vargas, conseguiu uma ajuda para o novo projeto encampado, no valor de 250 contos, com um banqueiro gaúcho. Dessa maneira nasceu, em novembro de 1928, no Rio de Janeiro, a mais importante revista ilustrada do século XX, embora sua consolidação tenha se dado mesmo na década de 30.

Para seu número de lançamento, houve um pesado recurso de divulgação. Cinco dias antes de a publicação chegar às bancas, foram lançados de altos prédios quatro milhões de folhetos, na Avenida Central. Chateaubriand apostou ainda num lançamento simultâneo, em várias capitais do país. Com tanto alarde, logo de início atingiu a venda de cinqüenta mil exemplares. Já para a estréia da revista, outra novidade: a capa colorida, além de contar com o gênero entrevista.

De propriedade dos Diários Associados, grupo que chegou a contar com trinta e sete jornais diários, em todo o Brasil, O Cruzeiro já saiu como revista semanal, mantinha agentes em todo o país, bem como correspondentes em vários países da Europa, além de outro em Nova York. A publicação podia ser conseguida nas bancas, em números individuais, ou por meio de assinatura, mesmo do exterior. Continha nesses primeiros anos, em média, sessenta e quatro página, das quais cerca de metade destinada à publicidade. Foi a primeira revista brasileira a atingir todo o território nacional.

O texto de apresentação do primeiro número justificava o nome da revista, relacionando-o à História do Brasil e também ao cruzeiro, um símbolo cristão. O grupo Diários Associados afirmou, no número um da publicação, depositar nas mãos dos leitores a revista mais moderna do Brasil.

Outro recurso inovador, de cunho auto-promocional, eram os prêmios distribuídos, como o incentivo a concursos e, já no número de lançamento, promoveu-se um concurso de fotografia. O sucesso não tardou e, poucos meses depois de ter sido lançada, tornou-se a grande revista do país. Após emplacar, O Cruzeiro alcançava, em média, duzentos mil exemplares em cada tiragem. Houve, todavia, edições com setecentos mil exemplares vendidos. 
As estratégias para conquistar leitores continuavam e eram variadas, como propor manter contacto direto com o público, recebendo cartas em diversas seções. Por rigor de Chateaubriand, durante algum tempo as revistas eram impressas na Argentina, por este não gostar da qualidade técnica das gráficas brasileiras. Talvez por causa desse tipo de exigência de quem comandava a edição da revista, chame tanto a atenção o fato de esta ser tão colorida e rica em fotos de muita qualidade, se comparadas a outras revistas em circulação no Brasil e em Portugal, na mesma época.

A mulher tinha espaço garantido e era sempre um público a ser constantemente alvo. Na seção "Dona", esse alvo era ainda mais delimitado: a mulher de melhor poder aquisitivo, a leitora da revista. Havia, ainda, espaço para cinema, esporte, culinária, coluna social, moda, charges internacionais e saúde, na seção "Consultório Médico", em que um médico respondia às dúvidas dos leitores. Com tanta variedade, numa época de poucos recursos para entretenimento, não é de admirar que o público leitor fosse variado e facilmente conquistado.

Mesmo com tantas seções, era rara a página sem publicidade e a ilustração era sempre um destaque d'O Cruzeiro. O caráter mais nacionalista dominava o discurso da revista. Em datas nacionais significativas, O Cruzeiro direcionava alguns textos para a política interna. A revista mostrou oscilar apoio e ataque durante a era Vargas. Em alguns momentos explicitava o apoio claro e incondicional a Getúlio Vargas, em especial durante o Estado Novo e, em outros, uma oposição forte e desconfortável para o governo

Poucas mudanças se notaram nos anos seguintes, mas a partir de 1935 as páginas da revista contaram com um número ainda maior de fotos e mais seções destinadas a mulheres, como foi o caso de "Mãe" e "Filhos".

Os negócios de Chateaubriand passaram a ocupar uma sede própria, para onde também se mudou $\mathrm{O}$ Cruzeiro, um arranha-céu, assinado por Oscar Niemeyer. Chateaubriand seguiu ampliando fortemente seus negócios, em pouco tempo anexou ao seu império trinta e cinco emissoras de rádio espalhadas pelo país. Para conseguir tanto sucesso nos negócios, em especial na área da comunicação, o embaixador contava com os melhores jornalistas do Brasil, sem contar sua forte influência tanto no meio político, como no meio empresarial e na sociedade mais abastada de todas as regiões do país. 
O Cruzeiro passava pela caneta dos importantes jornalistas e, por mais de quarenta anos, teve por diretor de redação o médico e jornalista Accioly Neto, acrescentando-se um grupo seleto de colaboradores, dos quais alguns viriam a compor a Academia Brasileira de Letras, como os ilustres Carlos Castello Branco, José Cândido de Carvalho, Herberto Salles, Lêdo Ivo e Rachel de Queiroz.

A sensível mudança editorial na revista Cruzeiro ocorreu em 1940, em que o estilo de reportagem investigativa passou a ser o tom de uma nova maneira de fazer jornalismo. Dessa forma, o período ficou marcado por notícias que culminariam com a Segunda Guerra Mundial, sem deixar de lado textos noticiando a vida das estrelas de Hollywood.

No ano de 1945, a revista contou com mais novidades. Entrou, na primeira página, um índice, ao lado de um artigo. Foi desse período o início de uma dupla, o jornalista David Nasser e o fotógrafo Jean Manzon que, aos poucos, virou sinônimo da revista de Assis Chateaubriand. O fotógrafo chegou ao Brasil em 1943, após ter prestado serviços para uma publicação francesa, a revista Paris Match. Ambos foram os responsáveis por grandes reportagens e Manzon introduziu um novo tipo de fotojornalismo, com fotografias mais dinâmicas.

Foi, contudo, em 1944 que não só a revista, mas a dupla Nasser e Manzon ganhou ainda maior notoriedade, também em outros sessenta países, pela publicação de uma matéria intitulada: "Enfrentando os Xavantes", uma edição com dezoito páginas com fotos dos chamados selvagens em ataque de flechas e golpes, bem próximo do avião em que estavam os autores da reportagem. Há quem tenha julgado a estratégia dos mencionados profissionais uma forma de não só apresentar o desconhecido, o pitoresco, como também de se mostrarem como corajosos, valentes; já que estiveram tão próximo do perigo: os índios Xavantes. Uma das fortes características da dupla era o desenvolvimento de matérias com temas polêmicos.

Nos anos seguintes, notou-se um maior destaque para as páginas que se destinavam ao humor. Somado ao "Pif-Paf", de autoria de Millôr Fernandes, surgiu a extremamente popular charge "Amigo da Onça", do pernambucano Péricles de Andrade Maranhão, que apresentava sempre um tema cotidiano. O Cruzeiro normalmente ia para as bancas, tendo como capas modelos, atrizes, mulheres bonitas. Raras foram as vezes em que a capa destacava alguém do meio político. Segundo o verificado em alguns dados recentes, a 
revista ainda conta com recordes não quebrados, além de sua longevidade. A revista passou por alguns pequenos períodos sem publicação, mas circulou, sem interrupção, de 1943 a julho de 1975.

Foram vários os fatores que levaram ao fim da revista. O Regime Militar, segundo indícios, ajudou na promoção e na ascensão das Organizações Globo, fortíssima concorrente, somando-se ao fato de os Diários Associados virem perdendo prestígio. Em 1968, Chateaubriand morreu e o grupo não viu alternativa, se não se desfazer, aos poucos, de seus veículos.

Antes de seu fim, a revista enfatizou a publicidade, deixando as grandes reportagens num segundo plano, o que resultou em uma queda vertiginosa de venda. Como conseqüência, o grupo alterou sua periodicidade para mensal.

A revista que era destinada à classe média, mas também à elite, que trazia muitas e diferenciadas seções, com relevantes reportagens, saiu do mercado defasada. Com seu encerramento, abriu-se o espaço para a Realidade e para a recém-nascida Veja.

\subsection{O olhar da Análise do Discurso}

Em nossas análises recorremos à $\mathrm{AD}$, além de partirmos de alguns conceitos presentes especificamente na obra de Bakhtin "Marxismo e Filosofia da Linguagem". Detivemo-nos mais na questão do dialogismo, da polifonia, ou seja, afinamos nosso olhar para as vozes presentes nos textos.

Recuperando idéias basilares de Bakhtin (2004), no que se refere ao caráter dialógico da palavra e polifônico do discurso, buscamos essas vozes, explícitas ou não, mas presentes em textos variados da mídia impressa. Essa busca, consolidada pela materialidade lingüística, verificada pela escolha do tempo verbal, pelo uso do discurso direto ou do discurso indireto, pela reiteração de idéias percebida com a utilização de certos advérbios, pela modalização de afirmação, possibilitada, às vezes, pelo uso de determinados adjetivos, bem como a própria divisão em termos de diagramação do texto, no seu plano de expressão verbal e no plano de conteúdo. Isso tudo propiciou-nos depreender com um pouco mais de clareza se não a ideologia, ao menos algumas marcas ideológicas, até mesmo em virtude da 
opção por ora tratar, ora não tratar de alguns temas em voga no período, sem deixar de levar em conta que a imprensa, de forma geral, estava em alerta.

Em virtude desses caminhos, objetivando a composição de textos nas mencionadas revistas, foi-nos possível verificar marcas do ethos desse importante meio de comunicação, capaz de mostrar e também de omitir o que se viveu naquele intenso e emblemático ano de 1968. 


\section{CAPÍTULO 5 - ANÁLISE DAS REVISTAS}

Somos mortais porque vivemos no passado e no futuro. (...) embora a vida de uma pessoa seja composta de milhares $e$ milhares de momentos e dias, esses muitos instantes e esses muitos dias podem ser reduzidos a um único: o momento em que a pessoa sabe quem é, quando se vê diante de si.

Jorge Luis Borges.

\subsection{REVISTA FLAMA}

\subsubsection{Flama, número 1049, ano XXIV, de 12 de abril de 1968.}

Como o comum às revistas, o sumário traz o conteúdo da publicação, dividido em seções. Algumas foram verificadas em todos os números, enquanto outras contidas em números específicos. A Flama trazia, normalmente, as seguintes seções: "Especial", "Actualidade", "Reportagem", "Crônicas", "Rubricas" e "Da mulher". Verificamos a presença das seguintes seções, em alguns outros números: "Desporto", "Inquérito", "Concurso", "Exclusivo". Esse item nada mais era do que uma reportagem acerca de um assunto que envolve pessoas de certo destaque, por questões políticas, esportivas ou pela vida social que levam.

Com a necessidade concreta de delimitar nossa leitura e análise da revista Flama, como um todo, concluímos que o recorte em torno de um texto com enfoque político, além da menção ao que havia sido eleito para capa de cada número nos seria farta fonte para nosso estudo. Assim, exploraremos, não de forma central, a título de descrição a reportagem cujo assunto foi enfático para a revista, a ponto de ser escolhido como capa. Na seqüência, selecionamos um texto, por número analisado, da seção que trazia uma ou mais matérias relativas a uma abordagem de assuntos relacionados à política externa ou interna.

Antes de iniciarmos uma leitura e uma descrição da reportagem referente à capa e, em seguida, uma análise mais apurada de outro texto, com cunho mais político, cumpre que esclareçamos nossa consciência sobre alguns conceitos. Com base em algumas teorias, em especial da área da Comunicação, compreendemos haver uma distinção entre textos do 
gênero de informação da imprensa reportagem, notícia e artigo. De forma sintética, a distinção dos gêneros, de acordo com o Manual de Redação de o Estado de São Paulo, de 1997 sugere que a reportagem difere da notícia pelo conteúdo, extensão e profundidade. A notícia, de modo geral, descreve um acontecimento e, às vezes, seus efeitos.

A reportagem pretende ir mais longe. Parte do que é noticiado e desenvolve uma sequiência investigativa, o que não é o caminho seguido pelo gênero notícia, que se detém na apuração dos fatos, mas não suas razões. Essas diferenças podem muitas vezes não ser sentidas para um leitor menos preocupado com isso, mas encontram-se muito bem definidas e delimitadas nos variados manuais de redação e de estilo, bem conhecidos. Todavia, como isso não configurará em alterações no tocante a nossa análise, usaremos, indistintamente, as palavras reportagem, matéria e artigo.

A capa da revista em questão apresenta a cantora Massiel, a espanhola vencedora do festival da Eurovisão, ocorrido em Londres. Já na capa há a menção à marca patrocinadora da reportagem feita para o evento: "Menina Pescadinha".

Esse número da Flama traz, em seu sumário, além das seções comuns aos outros números, a seção "Inquérito", com reportagem sob o título "Portugal de capa e batina Lisboa: perfil do universitário". A matéria ocupou, entre texto e fotos, cinco páginas e traz, ao final, a informação da continuidade da matéria, no próximo número. Também há a seção "Desporto", na última página da revista, com texto sob o título: "O Sprint final do campeonato: Benfica e Sporting na hora da verdade"; a seção "Concurso", acerca do sorteio: "É quem é" e "Exclusivo", reportagem intitulada "Romy Schneider: nunca é tarde para recomeçar". Ao lado do sumário, há uma coluna: "Aos leitores”, em que, em nome da revista, deseja-se uma feliz páscoa, maneira de sempre deixar patente a religião por condutora da revista, e chama a atenção do leitor para a reportagem sobre o festival da Eurovisão. Há claro auto-elogio não só pela qualidade da cobertura do evento, mas pela rapidez com que a equipe da revista conseguiu pô-la nas bancas.

Além dessas seções, encontramos no presente número as habituais: "Actualidade", em que o subitem "Em foco nacional" traz pequenos textos, todos relativos a várias manifestações culturais, que vão dos livros, passam pela música, pelo cinema, pelo teatro e finalizam com exposições. A seção "Reportagem" vem com sete itens, dos quais vão da política à vida cotidiana de um trabalhador; um texto sobre envelhecimento; o agraciamento 
de um monsenhor, Avelino Gonçalves; além de um texto sobre uma fábrica de vidro e um artigo sobre literatura infantil. Contou, ainda, com um texto sobre Bob Kennedy, com o título: "Bob Kennedy: o homem que ninguém conhece". Essa foi uma reportagem que ocupou muitos números da revista. Uma grande matéria dividida em seis números. A família Kennedy teve muito espaço na Flama em 1968. Excetuando os números cuja reportagem explorava a vida de Bob Kennedy, outros números trouxeram textos sobre Edward Kennedy, além de uma capa com a foto de Jacqueline (ex-Kennedy).

Na seção "Crônica", há um texto sobre medicina, enfocando a enxaqueca. Quanto à seção "Rubricas", no item"Cartas ao Director", há duas, escritas por dois homens; programação de sete dias da TV; passatempos como: palavras cruzadas, humor, este com charges, menção a alguns discos; o item Flash, com fotos de personalidades de certo destaque, em um evento e/ou momento especial; além da bastante lida página intitulada "Crododilo", que no presente número apresentou-se com uma variante: "Krokòdeilos". A seção 'Da Mulher” trouxe a moda primavera/verão 68.

Após esse breve olhar para a edição mencionada, partiremos, de fato, para uma leitura mais generalizada da matéria da capa, no número presente na seção Especial: "Tudo sobre o Festival da Eurovisão" e propriamente a análise da matéria, encontrada no item "Reportagem", com o texto "Israel: o muro da paz".

A reportagem da capa traz a bem conhecida estratégia para deter o leitor, ou seja, mesclar o texto com imagens. Somam-se vinte e três fotos, em sua maioria com a função de registro, na medida em que servem como referência, literalmente ilustrativa, sobre o evento. Um outro recurso, comum numa matéria longa, como esta que ocupou oito páginas, é dividi-lo em subtemas, todos relacionados ao assunto central. Esse recurso está presente e a matéria assim se apresenta: na página 35, há a manchete mais importante: "XIII Grande Prémio Eurovisão da Canção - Massiel: A Vitória ao nosso lado". Apesar de o texto não guinar do que vinha antes sendo explorado, na página 36 há um outro título central: "Massiel: 15 mil dólares por três minutos".

A imagem capital da matéria, a da espanhola Massiel, assim como a parte do texto que trata especificamente da cantora, ao longo do artigo vão se diluindo e surgem imagens dos outros participantes e informações variadas, tanto da noite do Eurovisão, como dos dias que 
o antecederam, a rotina nesse período e informações sobre alguns inscritos para o importante festival.

Na página 38, encontramos a manchete: "Carlos Mendes: comprou em Londres a camisola do festival. Preço: 70 escudos", além de subtítulos, com letras menores, relativos a outros pequenos textos, ainda do evento: "Desvalorização do "fair-play", "Aparatos (e boatos) da grande vedeta" e "Mendes - comportamento regular".

Na página 40, a manchete é: "Londres: um verdadeiro "cocktail" de estrelas". A reportagem abre um pequeno espaço para falar e mostrar algumas imagens dos outros participantes.

Passamos a análise do texto que se encontra na seção "Reportagem": "Israel: O Muro da Paz”. Nas páginas seguintes, há a reprodução do texto veiculado pela revista. 


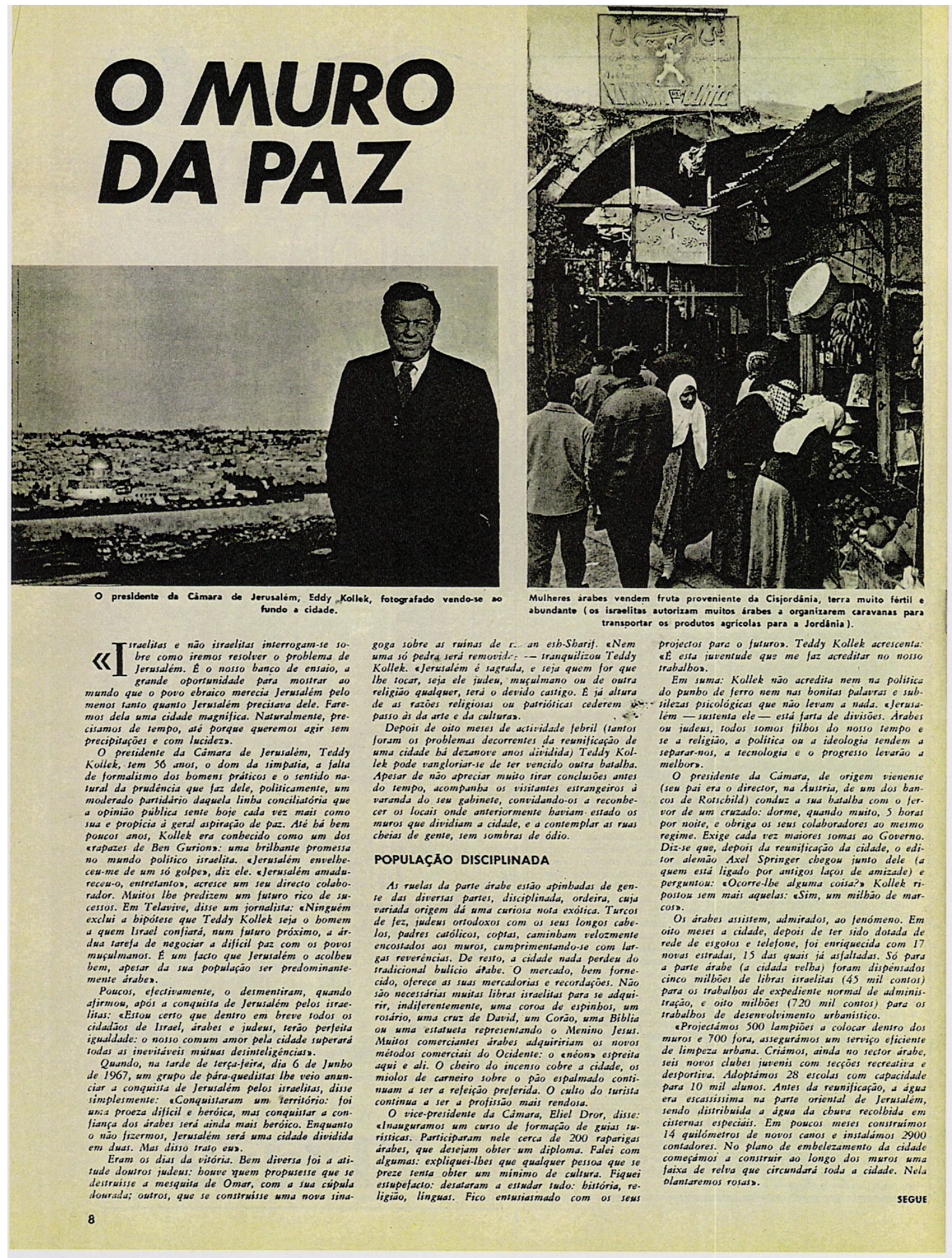



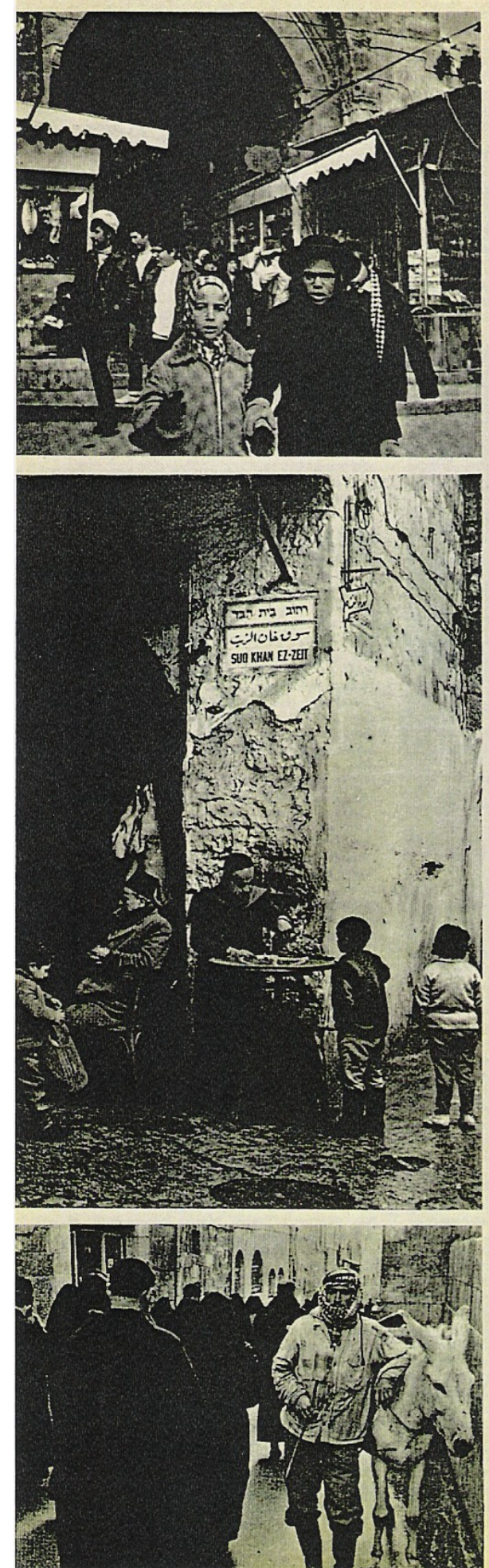

Nas très fotos do esquerda vé-se: a rua Dolorosa, í

velha de Jerusalém, um vendedor ambulanto vonde fatias

dum doce local. Ao seu iado o dono dum asougue

entrade pare o lobirinto de ruse da caro vollo:

da porth do Demasco. Na parte velhe do Jorusalím

preços de muitos góneros săo mais baratos que na

suas compras desto leva.

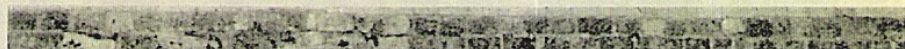

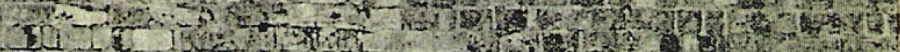
12.

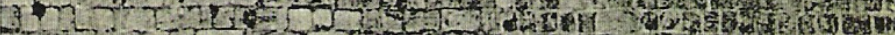

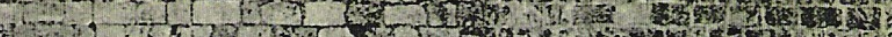

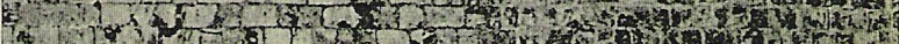

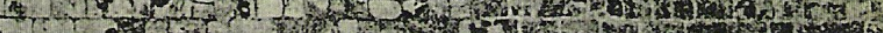

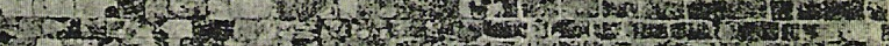

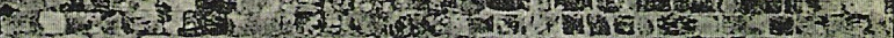

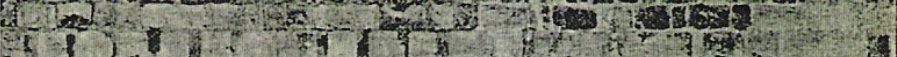

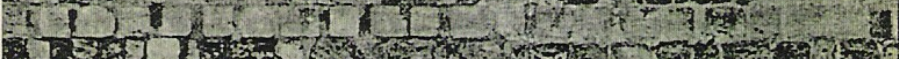

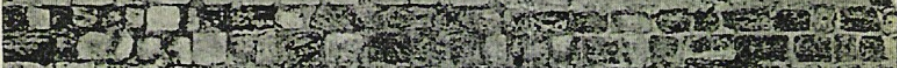

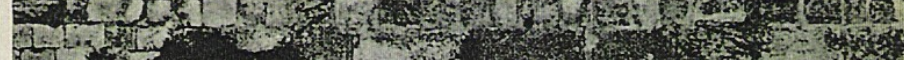
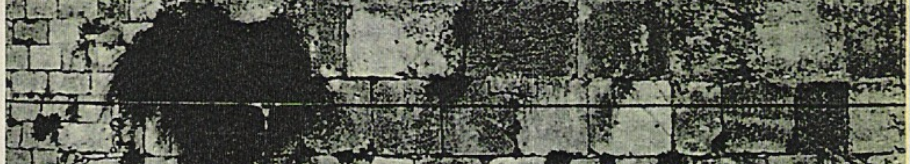

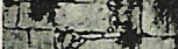

12
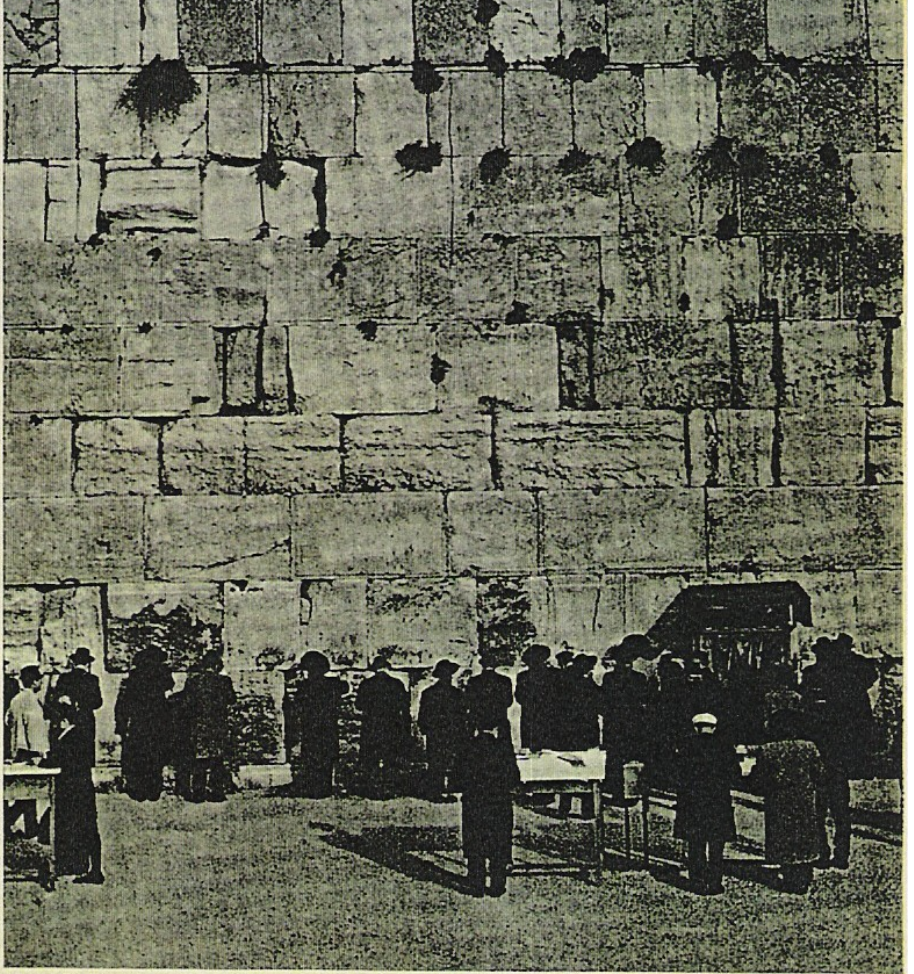

As podras salgadas. O muro das lamentasōess tom do altura corces de 35 metros a 80 de

lergura. E tudo o quo rests do templo destruido polos romanos em 70 d.C. 


\section{O MURO DA PAZ}

CURSOS DE HEBRAICO

Um padre franciscano que vive bid muitos anos em Jerusalem afirmou: ¿Os árabes näo são resigna. dos. Ná digo que näo apreciem alguns esforf̧os dos administradores de Jerusalem, mas sei tambem que ciso näo esquecer que os constrastess ultrapassam limites desta cidade aue é, como todas as vísimas, enganadoras.

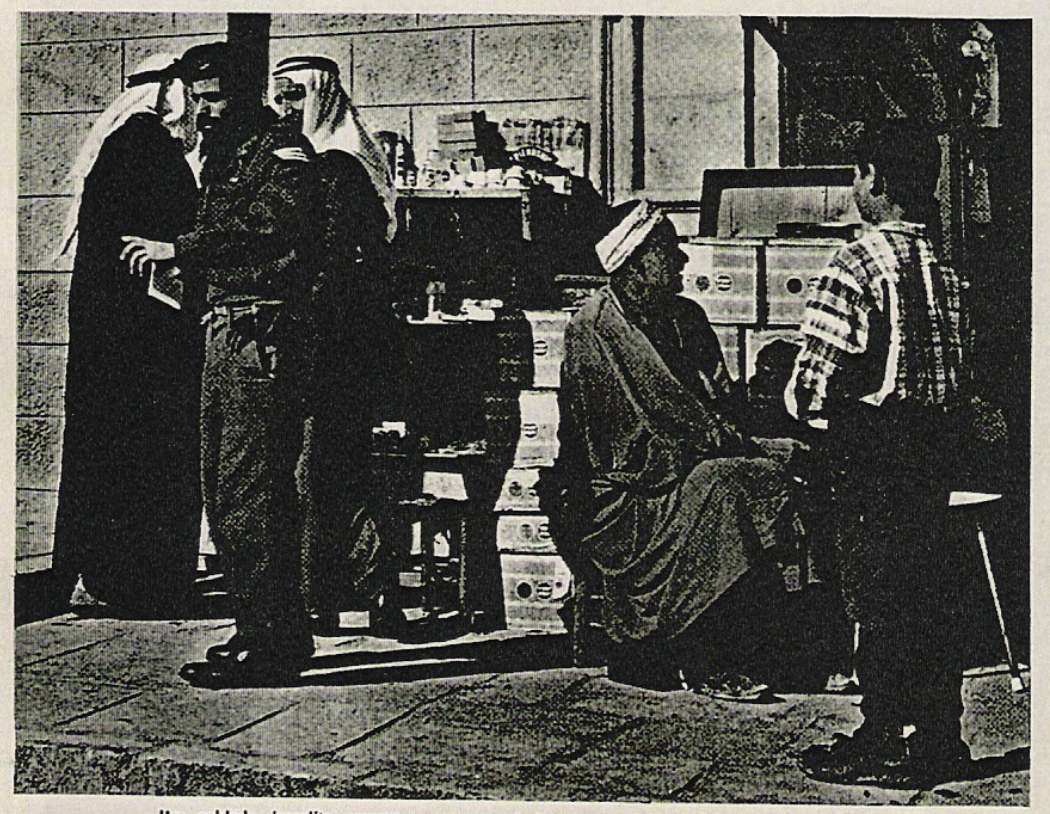

Um soldado israelita compra uma srecordaçaon numa lois arato da parto velthe de Jervistom.

Os arrabes, neste campo, säo extremamente parcos de palatras. Alguns dizem: serusalem tem visio

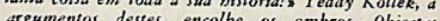
año me pasece a encolbe os ombros. Objecia dios de resistencia em Jerusalém. Bem pelo contrárion. Eis alguns episódios: 380 drabes, funcionário administratitios da cidade velha, voliaram ao ser vigo na Camara israelisa. Os vencedores organiz. trabalbo. Näo säo só eles que frequentam a escolo. Alguns professores da Universidade de Jerusalén que participam 400 muculmanos: homens de negócios, secretdrias, enfermeiras.

Depois de frequentarem um curso para aprender as leis 0 a lingua dos vencedores, boa parte do corpo de policia ex-jordana foi incorporada nos quadros oficiais da policia israelisa.

Cerca de 30 advogados e magissrados da velba Jerusalem recusaram.se a colaborar com os israeli. tas. O mesmo fizeram os velbos conselbeiros árabes, ainda que os convidassem a Darticipar na adminis-

Os israelitas säo particularmente duros com os
arabes que däo hospitalidade, escondem gem elementos hospiralidade, escondem ou prote lado do Jordío. $\vec{E}$ um facto que emientes do ousro se assinalam episodios de sabotagem grate ou de 10 dade bebraica: «Maitos árabes tém relutância em manifestar um excessito espirito de solidariedade, porque remem ser acusados de colaboracionismo no Particularmente descontentes está os propriets. rios dos 60 boteis diabes de Jerusalem. interrom. pidos os lacos com as agencias de viagem jordanos, estas näo conseguiram ainda reatar relaföes com propriestarios de boteis. eActualmente, poderosas so. ciedades israelitas estäo a construir, com capis americano, uma cadeia de grandes botéis: O She raton, o Hition, etc. Tambem a industria turistica grafas ao espirito empreendedor dos bebreus. D grafas ao espirito empreendedor dos bebreus. Du-

¿Jerusalem, do ponto de vista turistico, $\dot{\varepsilon}$ sm.

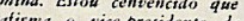

lembrando os grandes planos de festejos que se rea. lizaráo esta Primavera por ocasiäo dos 20 anos de
Estado (1948-1968). Na realidade, no quadro da iniciativas comerciais ligadas ao turismo, arabes israelitas mostram um cordeal entendimento. Come. cam if a surgir, por exemplo, pequenas sociedades, bebrea) que Ernst Jizchark Kabana (um negociante bebreu) fundou de colaboras com outro negoAse arabe: Kheirallab.

Ambos astutos e livres de preconceitos, foram ajsraelisa des o grande publicidade que a imprense agencia que se porpóa os membros das duas conir de medianeira entre negociar. Kabana e Kbeirallab oferecem sócios para empresas seguras, casas ou escritórios na cidade ve agencia of pars moesir dimberro. Actualmente agencia oferece, por aluguer, na cidade velha, so ou em qualquer outro canto da no batro arabo muito em mode entre os iovens, os arissas o lisera tos israelitas. Um representante da Junta Municipal lorneces a Kabana 9000 pedidos de apartamemtos do género. «Pelo menos, S000 destes pedidos seräo foi um dos primeiros israelitas a ter alugado um casa na cidade velba, para onde se mudou com

Tudo leva dgua ao moinbo da solidariedade. Es las aquisiföes creio que sáo musto aluspiciosas. Näo salis fevios duranie o anos - assegura kabana, que dirmos que babitar porta cow portas - diz Arich que faz parte do gabinete tecrico dependente primeiro-mimistro, instalado na cidade velba, encat regado de projectar a futura sistematizaça do cen tro bistorico de Jerusalem.

diz A lungao deste gabinete é muito imporsantes diz Teddy Kollok. aNäo tem apenas deveres técni estamos ainds, mum sociais e bamanos. Por enquamto

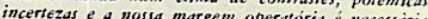
mente muito limiseds. $N_{0}$ fundo, of a necessaria. com maior desconfianfa säo os jrabes, a oue com preenderam que estamos animados por sentimentos de respeito pela sua arquisectura e pelos seus tem. plos, a parte da cilade mais atraente e mais suges. tivas. gabinete é composto por dois arquistectos, um urbanista e um administrador. A sua competência abarca todo o perimetro da cidade telha, ainda que protecsäo incidam apenas areas destruidas na guerra de Junbo e na de 1948 A cidade velba levanta namerosos problemos. Os rencedores, ou pelo menos uma parte deles, procaram que os arabes lbe perdoem o vandalismo que se seguin a reunificafáo da cidade, quando os mil: cares, sem o consentmento do Parlamento, abate musulmano: I35 casusta, toda uma ala do bairro rios recebersum casas demolidas, cujos proprieta. ¿ Uma destruicăos - dizio uma indemnizafäo. ponto de vista arquitectónico, sono, arambem do

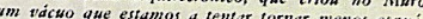
lido com obras puramente panorimicass.

Trasa-se de uma solufáa conciliatória. Os bebreus ortodoxos, no sen fanatismo, quando näo propōem abater a mesquisa de Omar ou de reconstruit templo de Salomáo (tornando fasal a barreira com carr mado mufulmano), sugerem projectos para colo. religiosos. modernas que näo ofendaus enconirar soluföes decidis deixar tudo como essa.
tungem, o Governo Isto significa que Teddy Kollek sbulanfas entre
dyus decisōes: procurar conciliar dyas decisōes: procurar conciliar vencedores e ven. anaticos compatriotas, por outro. Muitos confun. dem o valor politico e moral do sionismo com a missäo religiosa bebraica. slstael - diz Kollek A sua clarividéncia culsa, a auséncia de precon. A sua clarividéncia culsa, a ausencia de precon-
ceitos de bomem moderno, nem sempre encontram compreensäo fácil no clima de paixöes acesas que caracteriza ainda boje a vida de Jerusalém. Ao seu nome está ligada a realizafäo do magnifico Musen só pelos testemunbos bistóricics da sula pitria, mas pela arte em geral, e Jerusalem em particular. "Se pudesse, ele faria de Jerusalém um esplèndido mu. en. E ralvez consigan - disse Arieb Sonnino.

\section{DEMOCRÁTICOS}

Por ocasiäo do fim do Ramadio (a festa máxima
da religiäo mufulmana), nos muros da cidade velba apareceram mumerosos manifestos dam cidade velba de Teddy Kollek e de toda a Junta israelita na comunidade maometana.

o facto foi muiso apreciado pela comunidade arabe. Mas os drabes continuam a ser o ponto de incidencia dos sistemas democráticos de Teddy Kol. lek, que periodicamente organiza, com os outros seis vice-presidentes que compöem a Junta, debates Estas reuniöes, abersas a todos, decorrem sab lema: O cidadao pergunta, o Manicipio respondes. Num dos iltimos debates, alguns dirabes protess. ram porque as novas escritas toponimicas apareci. das em Jerusalem, na versáo drabe, apresentatiam graves erros orrográficos. \&Estou desolado, meus senhores. Podem ter a certeza que vou ver o que posso fazers. No dia seguinte, as placas desaparece.

0 sonbo de Kolleb é fazer de Jerusalém um centro universitário de cultsara e fé. Kolleh sabe que a realizar esta grande ambifäo sem de contar com rante o congresso internacional de afirma que adu. lizado recentemente em Israel so fratistectura rea. salém, de projecto: arquitectónicos andas de Jer dos para a zona destruida ou semi-destruida, inser. fáo de motivos modernos no contexto antigo, soly. föes talvez surrealistas. A verdade é que Jerusalén precisa, agora mais do que nunca, de bomen 
A reportagem escolhida para análise com maior profundidade, ainda da Flama de 12 de abril, não é assinada e ocupa três páginas. Tem por título: “O muro da paz”, um subtítulo, na primeira página da matéria: "População Disciplinada", mais dois subtítulos na terceira e última página "Curso de Hebraico" e "Sistemas Democráticos".

O texto jornalístico sem assinatura se não é, explicitamente um editorial, constitui-se em apagamento do sujeito/autor, em nome da linha editorial, carregado ideologicamente ao que foi sugerido pelo jornal e ou revista. Para Grillo (2004), nos gêneros informativos da imprensa, o sujeito enunciador apresenta-se ainda mais escondido que no discurso científico, o que ocorre por um apagamento das condições de enunciação do discurso jornalístico e uma utilização instrumental da linguagem, como forma de mostrar o tido por ela como real. Esse apagamento não quer dizer, no entanto, que não haja propriamente o aspecto subjetivo no discurso jornalístico, mas que, pela produção de notícias, constrói-se um discurso mais centrado em seu referente.

O título da manchete vem escrito com letras grandes e grossas, em caixa alta e esse uso não é ao acaso. Hernandes (2006) esclarece como se dá a utilização dos tipos gráficos, de acordo com sua significação. O autor afirma que as letras simulam o som. Dessa forma, o tamanho da letra relaciona-se com a altura da voz, que deve ser mais alta para uma notícia mais séria, mais importante. Esse recurso gráfico é convencional no meio jornalístico.

Como característica de revistas do gênero, além de um recurso importante do jornalismo e do próprio perfil da revista, mesmo numa reportagem que ocupa menos páginas, há muitas fotos. Apesar de a matéria não ser longa, o texto é grande e apresentado com letras bem pequenas.

A reportagem, em linhas gerais, em sua diagramação, conta com o aspecto verbal, além do fotográfico. Em termos de imagem, temos sete fotografias, todas com os devidos créditos. Dentro do Fotojornalismo, as fotos se dividem, segundo sua função, tomando por base a sequiência em que as mesmas apareceram. Respaldadas ainda em Hernandes (2006), julgamos que as cinco primeiras, além da sétima foto, são o que se conhece por foto de registro, aproximam-se de uma ancoragem para o texto. Já a sexta é chamada foto de síntese. Esta é mais adequada para representar a força expressiva do assunto abordado, no caso, o muro, que estimula orações, preces; ou seja, um caminho para a paz. Essa composição gráfica não ocorre de forma aleatória. A imprensa conta com um plano de 
expressão que não é apenas o verbal, a ela se associam vários elementos não-verbais, no caso em questão são as fotos, que compõem o todo textual pretendido.

Em razão da exploração desses recursos visuais, a página de um jornal ou de uma revista possibilita a leitura em duas velocidades. De acordo com Grillo (2004), a primeira leitura se dá de forma mais veloz e imediata, por corresponder à leitura dos títulos, das fotografias e das legendas, conforme estão organizadas na superfície da página. Já a segunda leitura é mais lenta e corresponde à leitura dos textos.

Como são muitas fotos, tomando-se por base o tamanho do texto, há que se refletir acerca do que se chama fotojornalismo, que nada mais é do que um gerenciamento do nível de atenção do leitor. A valorização desse recurso imagético tem crescido muito. De acordo com Hernandes (2006), isso acontece, tendo em vista uma aposta cada vez maior nas fotos para obter laços com os leitores. Ainda segundo Hernandes (2006, p. 214):

Uma fotografia deve ser uma das principais iscas para o olhar em uma página, ou seja, uma das mais importantes armas na estratégia de arrebatamento e de sustentação.

No que diz respeito ao texto verbal, encontramos passagens próprias de mais de um gênero do discurso secundário. Ao compararmos com reportagens atuais, com temas afins, ficam-nos mais claras as observações de Charadeau (2006) ao falar de uma certa evolução na estrutura dos gêneros do discurso na imprensa, embora essa evolução se dê de forma bem mais lenta do que ocorre com os gêneros do discurso na mídia televisiva.

$\mathrm{O}$ autor afirma que a imprensa do passado compunha artigos que apresentavam um desenvolvimento longo sobre as notícias do dia, a escrita aproximava-se mais de textos literários, havia uma menor visibilidade no anúncio das notícias e pouca distinção dos pontos de vista. Como há inúmeras diferenças na maneira de produzir os artigos, há também aspectos que naturalmente permanecem como, por exemplo, encontrarmos mais de um gênero do discurso em uma única reportagem.

No texto em questão, podemos verificar marcas do relato e também marcas do gênero comentário. Não desprezamos que haja posicionamentos diferentes quanto a esses gêneros, já que alguns julgam que ambos correspondem à tipologia narrativa, enquanto outros vociferam ser manifestações da tipologia argumentativa. Como não buscamos adentrar na 
questão da tipologia, limitamo-nos a apresentar nossa compreensão quanto à sutil distinção de um e de outro gênero.

Para nós, o relato segue mais os passos da narrativa, tendo por objetivo contar uma história ou acontecimento isolado. Já o comentário, como o próprio nome anuncia, propõese a apresentar um ponto de vista sobre o fato relatado. Obviamente, entendemos que esse posicionamento, na construção do comentário, é orquestrado por uma ideologia. Sendo então o comentário uma opinião, esta não pode ser tomada para enunciar uma verdade sobre o mundo. Como o comentário é construído por meio de critérios pessoais particulares, estes se apresentam passíveis de questionamentos e contestações.

Em “O Muro da Paz", encontramos dois planos de enunciação, o plano histórico da enunciação e o plano discursivo da enunciação. A distinção entre esses dois planos é atribuída a Benveniste (1995), que afirma ser próprio do plano histórico excluir marcas de referência ao momento da enunciação e comportar referências ao contexto. Ainda para o autor, o relato histórico apresenta os acontecimentos como pertencentes ao passado e sem referência a uma instância de produção, como se os fatos falassem por si. O comumente visto, nessa situação, é o uso de certos tempos verbais. São eles o pretérito perfeito, para pontuar algo como acabado; o imperfeito e o mais que perfeito, além do futuro do pretérito, que traz como efeito de sentido o aspecto condicional. Já o modo de enunciação discursivo caracteriza-se pelas marcas do momento da enunciação, verificados pela utilização de dêiticos de pessoa, de tempo e de lugar. Esse modo de enunciação discursivo apresenta um tom mais subjetivo e os tempos verbais mais freqüentes são o presente, o futuro e o pretérito perfeito. Apesar dessas distinções, o mais identificável é atribuir o uso do pretérito perfeito ao tempo da história, ao passo que o uso do presente ao tempo do discurso.

No artigo, sob a ampla "capa" da empresa editora da Flama, é possível detectar um grande número de vozes. Essas várias vozes materializam a chamada polifonia, como já exposto, um conceito atribuído a Bakhtin. Nos cânones da imprensa, a polifonia pode ser verificada em outros gêneros, concernentes à função precípua de um meio de informação, que é a de informar.

Antes de "desmontarmos" pouco a pouco o texto, passamos para uma síntese do que foi possível detectar, especialmente no que tange à polifonia, algumas marcas lingüísticas, como à sua organização, em termos de conteúdo. De partida temos, reproduzido por 
discurso direto, a fala de Teddy Kollek, que talvez como um simulacro, procurou mostrar, em alguns trechos, a voz sob a perspectiva de um homem, até certo ponto comum, todavia, por outro lado, em muitos momentos, o que mais se encontra é a fala de Kollek, sob a perspectiva de um político israelense, ou seja, conforme Foucault (1979) suas falas são pautadas pelo lugar de onde profere o discurso, assim como a situação vivida na ocasião. “(...) grande oportunidade de mostrar ao mundo que o povo ebraico 9 merecia Jerusalém pelo menos tanto quanto Jerusalém precisava dele". "Faremos dela uma cidade magnífica".

Na presente situação, essa é a voz representativa do discurso oficial. Esse discurso oficial ainda é verificado por meio da voz de colaboradores de Kollek: "Jerusalém amadureceu-o"; de um jornalista em Telaviv: "Ninguém exclui a hipótese que Teddy Kollek seja o homem a quem Israel confiará (...)”; do arquiteto italiano, que passou a morar em Jerusalém e a prestar serviço na área de urbanismo para a câmara da cidade: “(...) não há nada melhor, para nos compreendermos e fundirmos que habitar porta com porta". De certa forma, o discurso do poder é reforçado pela própria voz da Flama, que enaltece as qualidades do político, de algum modo, avaliza Kollek como um bom representante do povo de Israel.

Por outro lado, temos algumas outras vozes, mas com claro desprestígio quanto ao espaço para o que se pode entender como discurso oficial e discurso não oficial, no caso as parcas aparições literais da voz dos árabes, uma voz fraca ou enfraquecida, bem como a voz de um padre católico, residente no local. Não se pode deixar de frisar o pouco espaço concedido para os árabes, sobretudo os que não compactuavam com o governo israelita. Por exemplo, na passagem em que se mencionou uma nova tendência de alguns israelenses de procurarem apartamentos na região antiga da cidade, onde os árabes viviam: "Morar no bairro árabe ou em qualquer outro canto da cidade velha está muito em moda entre os jovens, os artistas e literatos israelitas”. Não houve nenhum depoimento sobre o que os árabes achavam desse movimento. Aliás, um movimento que poderia também ser entendido como uma nova forma de invasão.

Embora não tenha havido espaço para o árabe, quanto à procura por imóveis na região histórica, este, mesmo que de forma restrita, "soltou” sua voz, quando teve possibilidade.

\footnotetext{
${ }^{9}$ A palavra "ebraico" está sem h, já que foi reproduzida do texto original.
} 
Julgamos como um recurso inteligente da revista o fato de abrir espaço para essas falas, mesmo que de maneira minoritária. Parece-nos uma estratégia que contribui para que o leitor construa o ethos da revista como de um órgão da imprensa democrático, sincrético. Só pela perspectiva da religião, temos a voz dos árabes que seguem a religião muçulmana, a voz de judeus e a voz de um padre católico. Enfim, a revista promoveu uma manifestação polifônica e ecumênica.

Um aspecto lingüístico que pode fornecer subsídios no momento da análise fica por conta da utilização da voz passiva. Esta tem o "poder" de omitir o sujeito da ação, o que, às vezes, é uma estratégia ideológica para falar parcialmente sobre algo, ou ainda como forma de expor a limitação de uma pessoa, um grupo que se vê apenas como ser passivo de um acontecimento. Como exemplo de uso da passiva para omitir o agente de uma ação, apresentou-se apenas o fato, sem mencionar de quem partiu a referida ordem: “(...) convidando-os a conhecer os locais onde (...) haviam estado os muros que dividiam a cidade." No trecho, afirma-se apenas que os muros existiam no local, mas não se explicita quem os havia mandado construir. Por outro lado, há passagens em que o uso da passiva auxilia na demonstração da eficiência e da tolerância do governo israelita: “(...) a cidade, depois de ter sido dotada de rede de esgoto e telefonia, foi enriquecida com 17 novas estradas (...) foram dispensados cinco milhões de libras israelitas.” “(...)Depois de freqüentarem um curso para aprender as leis e a língua dos vencedores, boa parte do corpo da polícia (...) foi incorporado nos quadros (...) da polícia israelita”.

Do ponto de vista da organização, o texto apresenta uma divisão básica: a oposição entre o mundo árabe e o mundo israelense, este um mundo moderno e dito mais aberto que aquele, em que o vigente era o ceticismo e uma conduta mais retrógrada, para a época. Os recursos de uso da língua, ou seja, a própria materialidade lingüística, com a inserção de algumas palavras ou expressões que, com determinada carga semântica, contribuíram para essa visão dual da realidade vivida em Jerusalém em 1968 (e também ainda hoje, em relação aos palestinos). Alguns exemplos do acima afirmado são encontrados em; “(...) língua dos vencedores (...)”; “(...) negociar a dificil paz (...)”; “desintenligências”; “população disciplinada”, entre outros.

A voz do autor do texto, como já afirmado, misturou-se à própria voz da Flama, uma revista que se enquadrava, segundo seu posicionamento claramente católico, pelo que se 
sabe, sem sérios problemas com a política vigente, enfim, apresentou-se sob um ethos que foi sendo constituído ao longo de sua história de décadas.

O texto inicia com aspas, dando voz ao presidente da Câmara, ao mencionar o que se presume como parte de um diálogo, uma resposta a uma pergunta. No caso, esta teria sido proferida por vozes coletivas, as dos israelitas e dos não israelitas, que viviam próximos. Se a pergunta é a mesma, as orientações ideológicas e religiosas não são. A fala de Kollek abordou o problema que assolou Jerusalém, após a criação do Estado de Israel, em 1948, agravado pela invasão do local, em junho de 1967.

Logo no início do parágrafo, o político afirmou: “(...) grande oportunidade de mostrar ao mundo que o povo ebraico merecia Jerusalém pelo menos tanto quanto Jerusalém precisava dele". A utilização do verbo "precisar" pode ser entendida como forma de mostrar o sentimento de necessidade recíproca. No trecho, a fim de explorar o apelo emocional, o recurso lingüístico utilizado foi a personificação do local. Sem dúvida, uma maneira de não só justificar, mas amenizar as ações israelitas, em Jerusalém, em decorrência da "conquista" do território. Segue com uma promessa: "Faremos dela uma cidade magnífica". Promessa, aliás, bastante presente no discurso de tantos políticos.

Assim como ocorreu no primeiro parágrafo, em vários outros momentos, ao longo do texto, há espaço literal para as pessoas que, envolvidas no tema central da matéria, são apresentadas por meio do discurso direto. Alguns exemplos: voz de Kollek: “(...) o povo (...) merecia Jerusalém (...) tanto quanto Jerusalém precisava dele”; a voz de um colaborador do político: "Jerusalém amadureceu-o"; voz de um árabe: "Jerusalém tem visto tanta coisa (...)”. Contudo, vemos uma distribuição desigual das vozes. O político judeu, seus colaboradores e quem mais se mostrou simpático à atuação israelita no poder teve certo privilégio. Isso nos parece uma marca pontual do posicionamento da revista, além de ser a forma de demonstrar como reproduzem a realidade dos fatos.

O segundo parágrafo do texto ficou por conta de uma descrição muito simpática ao presidente da câmara, a quem a Flama afirmou: “(...) tem (...) o dom da simpatia (...) o sentido natural da prudência, o que faz dele um moderado partidário daquela linha conciliatória (...) propícia à geral aspiração de paz”. Segue com comentários elogiosos: “(...) brilhante promessa no mundo político (...)”. O parágrafo traz ainda, também em discurso direto, a afirmação de Kollek: “Jerusalém envelheceu-me de um só golpe", segue- 
se uma outra afirmação que suaviza o verbo "envelhecer" e este é substituído por um colaborador seu, ao dizer: "Jerusalém amadureceu-o". A retificação feita, por meio da troca dos verbos, só vai acrescentar dados favoráveis à figura do Presidente da Câmara. Nesse trecho temos claras três vozes: a do jornalista, que se camufla no "eu" da revista; a do presidente da câmara e de seu colaborador.

De acordo com Hernandes (2006), no texto jornalístico encontram-se quatro tipos de sujeito do texto. O que chama de sujeito 1, jornal: diz respeito a quem assume o discurso em um noticiário; sujeito 2, profissionais, são os jornalistas, os analistas, os colaboradores que escrevem e permitem que o leitor construa a hipótese da linha editorial do veículo em questão; sujeito 3, em que estão presentes personagens das histórias que aparecem nas narrativas, em reportagens e análises. É possível exemplificar um personagem de uma matéria, o político Kollek, presidente da câmara de Israel, no ano de 1968. Por último, o sujeito 4, este é representado pelo público ou consumidor do produto jornalístico: cada jornal ou revista faz menção a ele de maneira distinta, pode ser o leitor, o telespectador, o ouvinte.

No caso trabalhado, como o texto não é assinado, até entendemos uma possível mescla entre dois tipos de sujeito, o 1, o próprio órgão da imprensa, que assume a voz como responsável pelo conteúdo, como a do sujeito 2, ou seja, os profissionais, analistas, colaboradores que, por meio do texto, ajudam a compor o ethos do próprio jornal ou revista. Por outro lado, nas passagens em que o predomínio é a do relato, com uso do discurso direto, encontramos o sujeito 3, os personagens das histórias. A própria opção por um ou outro tipo de sujeito já é marca clara do efeito de sentido pretendido, o que se dá segundo uma perspectiva nitidamente ideológica.

O segundo parágrafo foi concluído, com a reprodução, em discurso direto, do afirmado por um jornalista em Telaviv: “Ninguém exclui a hipótese que Teddy Kollek seja o homem a quem Israel confiará (...) a árdua tarefa de negociar a difícil paz com os povos muçulmanos. É um facto que Jerusalém acolheu bem, apesar da sua população ser predominantemente árabe”. Para reafirmar o caráter polifônico, outra voz é requisitada.

No terceiro parágrafo, observamos estratégias para continuar com uma avaliação positiva de Kollek. Ele disse "na perfeita igualdade” entre árabes e israelenses. O propósito de convencer o leitor parece bem sedimentado, inclusive com o uso enfático do 
adjetivo "perfeita", para demonstrar o ethos de um governante simpático e propagador da igualdade. Esse tipo de afirmação pode ser entendida como um recurso retórico de um político que governa uma cidade, cuja maioria não é do seu povo, o povo judeu.

O político ainda contemporizou, ao dizer que: "O nosso comum amor pela cidade superará todas as inevitáveis mútuas desinteligências". Forma bastante apropriada para buscar um certo apoio de árabes, por não atribuir a esse povo o que ele chamou de "desinteligência". Fez menção à conquista de Jerusalém pelos israelitas, utilizando marcadores temporais precisos, como "em junho de 1967", ao afirmar que, embora fosse importante conquista, o necessário seria conseguir a confiança dos árabes, pois do contrário a cidade permaneceria dividida e finalizou o comentário, com outra promessa implícita e senso de dever que cabia ao cargo: "Mas disso trato eu".

Mesmo que implicitamente, o político invocou a ação mais heróica do que a dos páraquedistas mencionados, quando do período de retomada de Jerusalém, a que estaria em suas mãos, conseguir a união dos povos, de forma pacífica e de olho no futuro. Ou seja, a tão árdua tarefa não caberia em mãos de um herói que não tivesse seu vulto. Kollek assumiu o ethos de um "salvador da pátria", (aliás, uma pátria multifacetada) que olhava por todos e colocava a arte e a cultura, de distintos povos, como superior a questões religiosas ou nacionalistas. A composição do próprio ethos parece cuidadosamente construída. Em sendo um homem que valorizava as variadas manifestações artísticas, é possível olhá-lo, além de tudo, como uma pessoa sensível. Essa parte do texto termina com o convite de Kollek para: "contemplar as ruas cheias de gente, sem sombra de ódio". Enfim, até acabar com o ódio entre povos Kollek, pelos dados do texto, teria conseguido.

A segunda parte da reportagem vem com o subtítulo: "População disciplinada", em que se descreveu a zona árabe de Jerusalém, com gente oriunda de diversas localidades. São turcos, judeus ortodoxos, padres católicos. Esse trecho do texto apresentou o povo árabe como disciplinado e ordeiro. Há que se refletir se ambos os adjetivos não parecem bastantes propícios para se referir a uma pessoa ou a um grupo que, por inúmeras questões e situações, encontrava-se se não abaixo de outro, talvez servindo ou aceitando as imposições.

Para mencionar uma característica do local, o governante garantiu: "De resto, a cidade nada perdeu do tradicional bulício árabe”. Essa referência nos parece como quase 
mercadológica, o que hoje chamamos de "marqueteira", pois não podemos nos esquecer do contexto, ou seja, uma voz oficial, a qual apresentava suas ações no governo e seu explícito projeto de explorar a vocação da região para o turismo, muito por causa das tradições árabes.

Falava-se do também variado mercado dessa parte da cidade: "Não são necessárias muitas libras israelitas para se adquirir, indiferentemente, uma coroa de espinhos, um rosário, uma cruz de David, um Corão, uma Bíblia ou uma estatueta representando o Menino Jesus". De maneira não necessariamente verbal, todos esses símbolos são representativos de determinadas vozes, que se manifestam em imagens e objetos alusivos às religiões. Na passagem, de certa forma, ressalta-se a tolerância, no que se objetiva passar para o leitor, sobre a convivência de povos seguidores de religiões diferentes.

Com o trecho reproduzido, podemos fazer uma leitura de que a reunificação foi mesmo benéfica para o local, a ponto de pessoas, com crenças e religiões distintas, não só viverem próximas, como, de algum modo, relacionarem-se. Nessa segunda parte do texto, mais uma vez verificamos ações positivas advindas de medidas da câmara da cidade, pela fala do Vice-presidente da Câmara, reproduzida em discurso direto, que contou à Flama terem aberto um curso para formação de guias turísticos e havia duzentas moças árabes inscritas. Ou seja, os árabes precisavam de ações inclusivas para tentarem, num futuro, uma vida melhor. As ações inclusivas foram possíveis, graças ao governo israelita, que se mostrava democrático e isento de preconceito. Essa segunda parte do texto foi concluída com a afirmação de espanto, por parte dos árabes, quanto às melhorias significativas em Jerusalém, em tão pouco tempo.

O recurso da personificação da cidade mais uma vez foi utilizado por Kollek, como é possível verificar no trecho: “Jerusalém (...) está farta de divisões”. Já no trecho: “Os árabes assistem, admirados, ao fenômeno (...)”, verificamos como ideológica marca da revista o uso do adjetivo "admirados". Ao se afirmar que os árabes estavam se sentindo admirados com o que presenciavam, não se disse, mas pelo contexto geral recupera-se a idéia de um povo cético. Para ratificar que os árabes tinham motivo para a admiração, listou-se um rol de melhorias relevantes, pelas quais a Jerusalém não cindida assistia.

Na passagem a seguir, retirada de mais um trecho, em discurso direto, da fala de Kollek, vemos, nas entrelinhas, que a reconquista de Jerusalém pelos israelitas, não só beneficiou 
todo o povo que vive no lugar, como retirou os árabes do atraso a que estavam submetidos. “Antes da reunificação, a água era escassíssima na parte oriental de Jerusalém”. A utilização do adjetivo em seu grau superlativo ajuda a recompor a atmosfera insalubre da vida dos árabes, antes do governo israelita assumir o poder da cidade.

O destaque a ser dado a Kollek, um político que, pelo artigo, mostrou-se flexível, em especial por crer que a tecnologia e o progresso levariam a melhor, numa guerra que envolveu religião, política e ideologia. Muito desse posicionamento só ratificou o político como um homem de seu tempo, mas de olho no futuro, e que se colocou favorável ao progresso, haja vista as melhorias em termos de saneamento básico, comunicações, entre outras, promovidas em poucos meses de seu governo. Ao mesmo tempo, era um homem austero, no que tangia ao trabalho. Conforme a informação, dormia pouco e exigia o mesmo de seus colaboradores.

Na página 10, a manchete é a mesma: “O Muro da Paz”, entretanto apresentado com tipos menores e juntamente com o subtítulo temos a terceira parte: "Curso de Hebraico" e, finalizando a matéria, a quarta parte: "Sistemas democráticos". A terceira parte do texto inicia com uma opinião de quem vivia em Jerusalém há anos e não era judeu e sim um padre católico. Para ele, o povo árabe não era propriamente resignado e, apesar de aprovarem algumas ações do governo israelita, não deixava de lado o que pensavam os resistentes. O padre apresentou sua opinião sobre essa convivência entre os povos e seu ponto de vista em relação ao árabe, estruturado pela revista em forma de discurso direto. Apesar de ter sido uma constante ao longo do texto e isso não se mostrar incomum para o gênero, há que se pontuar que a revista, ao dar a voz a um padre, o qual ponderava sobre a atuação do governo israelita e suas relações com os árabes pode demonstrar marcas de um jornalismo imparcial. Não nos parece que seja bem esse o caminho da revista, entretanto propiciava uma leitura nessa direção.

A maneira encontrada pela revista para também chamar para esse diálogo, construído por muitas vozes, mas quase sem alternância, já que majoritariamente eram vozes oficiais ou a serviço do governo, foi abrir espaço para que um árabe tenha se colocado: "Jerusalém tem visto tanta coisa em toda a sua história!”. Se claramente a frase diz pouco, o árabe pode ter usado, parodiando Orlandi (1997), uma forma de silêncio. Um silêncio não contínuo, mas expressivo. Uma marca sutil e, ao mesmo tempo contundente, nos limites 
desse pequeno enunciado proferido pelo árabe, fica por conta do uso do sinal de pontuação, a exclamação para demonstrar descrença, dúvida, cautela.

É apenas nessa parte da reportagem que não se vê o teor mais tendencioso, pró-Israel. Logo na seqüência, foram mencionados alguns episódios que confïmariam um governo conciliatório, por exemplo: "380 árabes, funcionários administrativos da cidade velha, voltaram ao serviço na Câmara de Israel'. Pouco mais para frente, o trecho justificou o subtítulo: “Curso de Hebraico”, ao citar o curso como prática do serviço público israelita, e acessível a todos: “(...) professores da universidade de Jerusalém regem um curso acelerado de língua hebraica em que participam quatrocentos muçulmanos”.

No entanto, num dado momento o texto deixou clara a posição dos judeus em relação aos árabes, pelo uso do adjetivo "vencedores", no trecho: "Depois de freqüentarem um curso para aprender as leis e a língua dos vencedores, boa parte do corpo de polícia exjordana foi incorporada nos quadros oficiais da polícia israelita”.

Houve menção, mesmo que passageira, aos intolerantes, tanto árabes como judeus, além da afirmação de que israelitas eram mais "duros" ainda com árabes que davam guarida a "elementos" vindos do outro lado do Jordão. O adjetivo "duros" no contexto já fala por si, não há nada de subentendido em sua utilização, já o uso do substantivo "elementos" pode ser uma marca pejorativa, provável na relação complexa dos povos em questão.

Um outro trecho também volta a abrir espaço para demonstrar o descontentamento de proprietários de hotéis, árabes que viviam em Jerusalém, uma vez que sofreram diretamente, como se nota no trecho: “(...) interrompidos os laços com as agências de viagem jordanas, estas não conseguiram ainda reatar relações com os israelitas”. Se não conseguiram, entende-se que tentaram e o aspecto isento de preconceito do governo israelita pode ser colocado em causa. A crítica prosseguiu, em especial no ramo da hotelaria, com a acusação de os judeus poderem contar com a ajuda de capital americano e citou-se o potencial de Jerusalém para o turismo.

Pelo subentendido da fala de um árabe, a descrença foi mais longe: "Duvido muito que nos dêem uma fatia desta enorme torta”; metáfora utilizada para se referir ao potencial turístico do lugar. A esse tipo de crítica, o vice-presidente da câmara de Jerusalém contratacou, dizendo que o resultado disso daria para todos, sem especificar claramente quem eram "todos" a que se referia. 
O texto, em mais de um momento, suavizou a tensa relação entre os povos, apresentando o fato de, na ocasião, não ser incomum a sociedade de árabes e judeus, em alguns empreendimentos. Não que isso não tenha ocorrido, mas pelas tensões históricas, estas devem ter sido largamente minoritárias, se não exceções.

No trecho: “(...) ajudados pela grande publicidade que a imprensa israelita deu a sua iniciativa (...)", vemos algumas palavras-chaves, para concluir o que essencialmente se procurou mostrar com a reportagem, em outras palavras, todos os aspectos bons da cidade existiam pelas mãos dos judeus. Obviamente que a publicidade a que se fez menção cumpriu com sua função, a de enaltecer os feitos do governo. E isso se deu amparado por recursos ideológicos, tanto quanto o efeito de sentido é também ideológico, no que se refere ao aparente silêncio dos árabes.

Para ressaltar o charme da cidade velha, a matéria mencionou a então recente "moda" entre "jovens" de habitar na região e que a procura por imóveis no local tinha aumentado. Aliar o substantivo moda ao substantivo jovem é uma estratégia própria da publicidade. Parece ser o par desejado por todos, ser eternamente jovem e ser jovem é dar valor para a moda e estar na moda. Se a moda é quase que intrínseca aos jovens "descolados" de todas as décadas, não parece menos verdade que a moda também é uma característica do meio artístico e literário, outros possíveis moradores para a região árabe, pois além de "modernos", "artísticos" deveriam ser pessoas sem preconceito.

Um nome de um judeu foi apresentado, como o primeiro a se mudar para lá. A fim de corroborar essa habitação em área comum a povos com diferenças marcantes, religiosas e culturais, o texto contou com a opinião de uma pessoa que pode ser tida como isenta e, ao mesmo tempo, com conhecimento para falar de moradia, um arquiteto, de origem italiana: “(...) não há nada melhor, para nos compreendermos e fundirmos que habitar porta com porta". A origem pode ser italiana, mas é bem possível que o arquiteto fosse judeu, se tomarmos por base o trecho acima, com utilização dos dêiticos de pessoa ao falar: "nos compreendermos", do que se pode ler “eles- os árabes; e nós- os israelenses". O afirmado é apenas uma nossa pressuposição, com base no subentendido pelo trecho.

$\mathrm{O}$ arquiteto era funcionário de um gabinete técnico e subordinado ao presidente da câmara, Kollek, um israelita, muito provavelmente um judeu. Nessa parte do texto, o jornalista voltou a dar a voz a Kollek, que via o gabinete como muito importante, já que sua 
função excedia a técnica e estética e se estendia aos aspectos sociais e humanos. Mesmo havendo a ressalva de que o trabalho estava no início e que havia polêmica e incerteza, atribuiu-se ao povo árabe a maior descrença ou desconfiança.

A fala de Kollek, aparentemente, mostrou-se contraditória, levando-se em conta o que foi dito por ele no início do texto, ao afirmar não haver ódio em Jerusalém e, no final do texto, para tentar justificar a descrença dos árabes afirmou: “A sua clarividência culta, ausência de preconceito do homem moderno nem sempre encontram compreensão fácil no clima de paixões acesas que caracterizam ainda hoje a vida de Jerusalém”. De certa maneira, o governante encontrou uma forma de não expor a verdade sobre uma convivência que não devia ter muitos caminhos para a serenidade, a que o político tentou demonstrar existir, em relação a esses povos.

Os israelenses voltaram a ser tratados como vencedores e no trecho que segue podemos verificar, outra vez, que além de promotores da paz e do progresso, os judeus sabiam pedir perdão: “Os vencedores (...) procuram que os árabes lhes perdoem o vandalismo que se seguiu à reunificação da cidade, quando os militares, sem o consentimento do Parlamento, abateram a golpes de picareta, toda uma ala do bairro muçulmano”. Ou seja, os atos não partiram dos vencedores, que respeitavam e sabiam conviver com os diferentes e, para reparar os erros desses militares, indenizaram quem sofreu com o ocorrido.

A finalização dessa parte da matéria é uma imensa lista de adjetivos e ações vindas de um homem que, pelo texto, é um ícone, um resumo do bem, do que é correto, justo e ainda preocupado com a cultura. Ao longo do texto, o povo judeu foi retratado como moderno, progressista, pouco preconceituoso, respeitoso, includente; ao passo que o árabe, também de forma generalizada, foi visto, apesar de majoritário em certas áreas de Jerusalém, como dependente do progresso promovido pelo judeu, um tanto quanto atrasado, desconfiado e com a crença infundada de que o território poderia voltar às mãos de Hussen; rei da Jordânia. Essa provável interpretação do texto, por parte do leitor, resulta de uma manipulação da revista, com objetivo de que o leitor construa um ethos dos israelenses, grande parte judeus, e um dos árabes. Com essa estratégia, percorremos, sem muita dificuldade, a trilha ideológica de certa anuência para com o povo judeu, detentor do poder, em Jerusalém. 
Como forma de demonstrar a aprovação a Kollek também do povo muçulmano, iniciouse a última parte da reportagem, mencionando-se manifestos de augúrios nos muros da cidade. Enfatizou-se o que ao longo de todo texto vimos ser trabalhado, o perfil de um governante, um homem com inúmeras qualidades e que acima de tudo prezava o respeito, pregava a tolerância e tinha os olhos voltados para o futuro, o qual poderia se mostrar promissor para uma terra rica em hábitos e costumes, além de próspero espaço para variadas manifestações artísticas.

A manipulação para convencer o leitor, quanto à maneira de ser dos povos retratados, prosseguiu quase até o final do texto. Ao se mencionar que alguns árabes manifestavam-se favoravelmente em relação a Kollek, propicia-se o entendimento de que também um grande número de árabes já tinha se convencido da importância política do presidente da câmara, um homem comprometido com os habitantes do local.

O teor democrático do trecho, que justifica o subtítulo: "Sistemas democráticos", como finalização da matéria, mais uma vez trouxe à tona o nome de Kollek, que juntamente com seus colaboradores, promoviam debates públicos, sobre os problemas dos bairros. Ressaltou-se que as reuniões eram abertas e sob o tema: "O cidadão pergunta, o Município responde”. Enfatizou-se o exercício da democracia, uma prática de Kollek, que além de todas as qualidades expostas, abriu espaço para um diálogo direto com os cidadãos, por meio dos encontros semanais, a fim de discutir melhorias para a cidade.

Para demonstrar a eficiência das ações de Kollek, aludiu-se à insatisfação de muitos árabes, por motivo de escritas toponímicas, na versão árabe, conterem erros ortográficos, em placas espalhadas pelas ruas. A isso Kollek afirmou-se desolado, o que atenuou o problema e reforçou sua presteza, pois no dia seguinte as placas desapareceram.

A conclusão do texto é a de que Jerusalém precisava de soluções para vários problemas e que quem podia sanar era a equipe de Kollek. Um de seus colaboradores, para demonstrar certa modéstia, terminou sua fala, reproduzida em discurso direto: "Esperamos estar todos à altura". Altura das expectativas israelitas e dita também dos árabes, em relação a esse governo.

A reportagem, em sua totalidade, traz marcas do plano histórico da enunciação; dito de outra forma, quando ocorre menção a fatos que pertencem ao passado, mas também encontramos o plano discursivo da enunciação, em que há uso de verbos no presente, 
predominantemente, e trechos com um tom mais subjetivo. $\mathrm{O}$ uso freqüente de verbos no presente é, também, um recurso lingüístico para transmitir a sensação de atualidade. Nos trechos em que a enunciação se reporta a fatos históricos, o esperado é uma maior objetividade. Analisando ambos planos, o histórico da enunciação e o discursivo da enunciação, deparamo-nos com muitas vozes, cada uma orientada por determinadas ideologias e objetivos. Essa polifonia apenas reforça nossa crença de que os órgãos da imprensa, a serviço de determinados grupos, utilizam as vozes de alguns para atingirem seu público-alvo, a fim de reforçarem suas próprias vozes, o que é uma forma de posicionaremse em relação a diversos assuntos.

Como uma conclusão do que se viu na matéria, há que se ressaltar alguns pontos. Apesar de a invasão de Jerusalém ter ocorrido num passado bem recente, tomando como referência a data da publicação da revista, o esperado é que houvesse, mesmo que brevemente, uma retomada desse período. Entretanto, notamos a falta de vínculo da matéria com a realidade histórica.

Enfim, no texto, a ação militar armada não entra em causa, ao contrário, mesmo que subliminarmente enfatiza-se a operação como benéfica, pelo uso do adjetivo "heróica", para designar a ação dos pára-quedistas, quando da invasão de Jerusalém. De todas as formas possíveis, legitima-se a ação militar e a ordem imposta, tendo esta como um fato propulsor de algo muito superior: a vitória do progresso, ou seja, a vitória de Israel sobre o povo árabe. 


\subsubsection{Flama, número 1068, ano XXV, de 23 de agosto de 1968.}

Na capa há uma foto, que ocupa pouco mais que a metade da página, e traz Hermínia Silva, um dos nomes mais importantes do Fado. A outra parte da capa fica por conta de quatro manchetes: "Dar de beber à alegria"- Hermínia Silva numa paródia ao êxito de Amália; "Teatro Grego em Portugal: juventude aos 2500 anos"; "Joaquim Agostinho: a grande revelação da volta -68" e "Festival de Espinho: uma atracção chamada Aznavour".

Esse número da revista apresenta, em seu sumário, as seguintes seções: "Especial", em que há continuação sobre a história pessoal de Robert Kennedy; "Actualidade", cujo subitem "Em foco", traz textos relativos à política externa além de questões internas a Portugal, não necessariamente sobre política e, ainda, o item "Telegrama", com pequenas notas, vindas de várias localidades, sobre assuntos variados. Na seção "Reportagem", há onze itens, que vão de uma matéria relativa a Éça de Queirós; um artigo sobre um locutor de rádio; a ida do teatro Grego ao país; a apresentação de Aznavour em Espinho; o destaque no esporte ciclismo; uma entrevista com a fadista Hermínia Silva; o festival de música da Costa Verde; um concurso de vestidos no Porto; a visita do cirurgião Barnad em Mônaco e finaliza com um corrida de touros. Na seção "Crônicas", há três itens: Cinema, com texto que se refere a uma comédia policial; Toiros, texto sobre uma atuação importante do toureiro Amadeu dos Anjos e, Medicina, com texto sobre a relação cigarro e câncer de pulmão.

Na seção "Rubricas", vemos nove itens, com temas que dizem respeito a limites de velocidade, "Cartas ao Director"; "Fotografe os seus filhos"; "Discos"; "Crocodilo"; "Desenhe um carro" e os passatempos como palavras cruzadas, programação da TV e o item "Humor". Por fim, há a seção: "Da Mulher", em que se dá destaque para a moda e para a decoração. Ao lado do Sumário, há menção a uma reportagem que comporá o próximo número e tem por enfoque os soldados portugueses em Angola.

Como o feito em relação ao número anterior, iniciaremos com uma leitura do texto que remete à capa: "Hermínia Silva - Dar de beber à alegria", matéria assinada por Manuela Alves. Antes de adentrarmos uma leitura panorâmica sobre o texto, julgamos como muito 
importante refletir sobre as pessoas que normalmente eram escolhidas para as capas da revista Flama.

Conforme o já exposto, apesar de nos limitarmos a três revistas Flama neste estudo, fizemos um acompanhamento mais longo, de suas publicações, em especial números após 1960. Destes, o constante e mais comum, para as capas, além de mulheres bonitas, eram pessoas que hoje poderiam ser chamadas de "celebridades", representantes dos círculos sociais com relativo poder econômico e alguma projeção, em virtude da profíssão. Contudo, há que se fazer uma ressalva, por exemplo, no que se refere aos nomes dos artistas escolhidos. Segundo o esperado para o contexto de um país que vivia sob uma estrutura política fechada, percebemos que o espaço era garantido para artistas que, a seu modo, pareciam ou compactuar ou pelo menos não se mostrar contrário ao Estado Novo. Essa ressalva foi feita, a fim de reafirmarmos, em relação a esse número, que a artista da capa era um dos ícones da música tradicional do país e que, de alguma maneira, compunha, em termos de música, o próprio quadro da era Salazar.

A reportagem ocupa quatro páginas. Na primeira, há predomínio do texto escrito e uma pequena foto da cantora. A segunda página traz uma foto de página inteira da cantora. A terceira e a quarta páginas da reportagem contam com mais três fotos, em que se vê Hermínia Silva, provavelmente, em sua casa. O texto começa com uma questão delicada: se há ou não rivalidade entre as duas grandes damas do fado, Hermínia Silva e Amália Rodrigues. Após a pergunta, a rápida e objetiva resposta, dada pela repórter: "Nada disso". Afirma-se haver admiração mútua entre ambas. A matéria apresenta-se, em sua diagramação, com letras diferentes, em itálico, no momento de reproduzir a fala da cantora. Apesar de não ser construída exatamente como uma entrevista, já que as perguntas não aparecem, remete a esse gênero, trocando-se a pergunta por um comentário, ao que se segue a fala de Hermínia Silva.

No decorrer do texto, fez-se menção à maneira distinta das duas maiores intérpretes do fado interpretarem as melancólicas canções. Hermínia Silva afirmou ter certa predileção para o que chama de fado alegre, ao que explica: “(...) as caricaturas são a minha especialidade”. Seguiu justificando ser o mais natural, bem ao gosto de Amália Rodrigues, cantar o fado sério sem luzes, de olhos fechados. Por outro lado, enfatizou também como adequada sua interpretação para aquele outro tipo de fado, o mais caricatural, ao que 
declarou: “(...) se o fado é alegre, olhando nos olhos do público e vendo-o a rir e a mexer a cabeça e o corpo, então deve-se cantar com a luz toda."

O texto seguiu reportando-se ao início da carreira da cantora, que além de cantar, também atuava como atriz. Contou-se um pouco da personalidade da fadista, como uma pessoa alegre e simples, que lidava bem com sua popularidade, de que tanto gostava. A intérprete justificou não ter mais trabalhado no teatro por pura falta de tempo, já que conduzia duas casas de fado, como proprietária e também com sua maneira particular de mostrar sua música. Houve espaço para mostrar um pouco do perfil de Hermínia, com seus gostos e rotina e a incógnita no que diz respeito à sua idade. Ao final da reportagem veio a notícia do lançamento de um novo disco, além de fazer uma participação num filme e a conclusão de que é uma pessoa realizada, verificável pela frase com que o texto é encerrado: "Tudo quanto sonhei se passou".

Na sequiência, passamos a análise do texto que se encontra na seção "Actualidade -Em foco", na parte destinada à economia: “E.U.A. e U.R.S.S. lado a lado”. Nas páginas seguintes, há reprodução do texto, veiculado pela revista. 
- A Fundafão Gulbenkian gastou, em Portugal, no sector da Saxide, 327593 contos, até ao fim do ano de 1967, a que se acrescentou já, no ano corrente, a verba de 37213 contos.

\section{ECONOMIA}

\section{E. U.A. e U.R.S.S. lado a lado}

A NOTICIA - Os Estados Unidos e a Uniāo Soviética deviam aliar-se para resolver os problemas do mundo: a sensacional proposta é do cientista soviérico Andrei Sakarov.

ENSAIO - Sakarov escreveu um ensaio intitulado Reflexōes sobre o progresso, a coexistência pacífica e a liberdade intelectuals, que tem a data de 1968. Nunca foi publicada na Uniāo Soviética e só agora chegou ao Ocidente, através das mesmas vias que zêm exportado tanta literatura clandestina. $\mathrm{O}$ New York Times: traduziu-o na integra e publicou-o. $\mathrm{O}$ documento é importante sobretudo pela personalidade do seu autor.

INFLUENCIAS - Andrei Dmitriyevich Sakarov nasceu em 1921 e é licenciado em Física (1947)

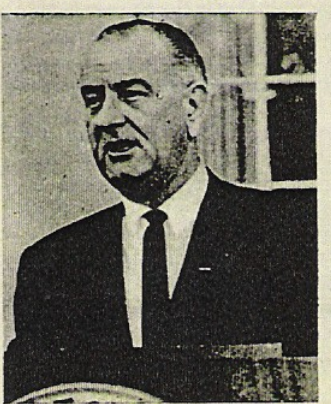

JOHNSON E BREZNEV

mios deden

pelo Instituto Lebedeo de Moscovo. Desde essa altura, tem tra balhado em intima colaboraçāo com Igor. Tamm, um dos três cientistas russos que, em 1958, receberam o Prémio Nobel da Física. Os dois cientistas foram eleitos para a Academia das Ciências (1953), na sequência das suas investigaçōes sobre o controle da fusāo termonuclear (aplicação pacífica do princípio da bomba de hidrogénio). Sákarov sofreu profundas influências do mestre, conhecido, também, pelas suas corajosas convicçōes - e posições de carácter político.
NAO-CONFORMISTA - Em 1966, mestre e colaborador enviaram uma petiçāo a Leonid Breznev, no sentido de que - no 23. - Congresso do partido comunista, não fosse reabilitado o regime estalinista, conforme era voz corrente nos círculos intelectuais moscovitas. Andrei Sakarov tem expressado as suas opiniōes inconformistas em artigos e ensaios, a que o regime jamais abria as páginas do ePravda mas que nem por isso deixaram de circular, dactilografados, nos meios científicos e culturais da União Soviética, sem quaisquer consequências funestas para o autor. Em « Reflexōes sobre o progresso» Sakarov define a crise checa como cuma significativa experiência para a definiçāo de uma nova forma política a meio caminho entre o socialismo e o capitalismon - E Sakarov concluiu: -Devemos apoiar esta audaciosa

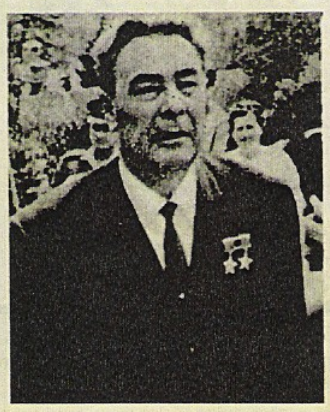

turo da Humanidade e do socialismo, com um apoio político e até económico». Esta posiçāo está longe de coincidir com a dos dirigentes russos no encontro de Cierna.

DADO CONCRETO - Para a sua original proposta de uma aliança EUA-URSS, Sakarov parte de um dado concreto. A Humanidade dividida está ameaçada de destruiçāo. Não há defesa possível, afirma o cientista, contra os mísseis estratégicos $\mathrm{e}$ as armas nucleares na posse dos russos e dos americanos. Para apoiar esta tese, Sakarov socorre-se da opi-

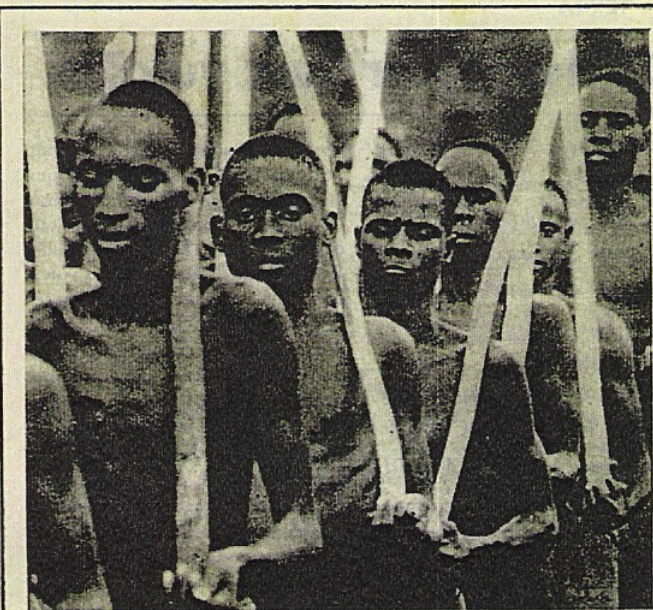

AS ARVORES MARCHAM DE PE - Voluntirios do exército de Biafro roce-

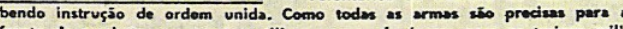
fronte do combate, os rocrutes utilizam ramos de irvore para os troinos mili-

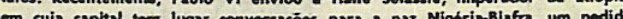

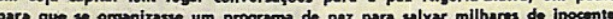

nião de Haris Bethe, Prémio Nobel da Física de 1967, publicado no número de Março da revista «Scientific American》, uma revista que não circula oficialmente na Uniño Soviética. Antes de mais é necessário abandonar os crité é necessário abandonar os crité-
rios actuais da diplomacia interrios actuais da diplomacia interclusivamente, a máxima vantagem para os próprios interessados e o máximo prejuizo para qualquer interlocutor.s 0 actual sisquer interlocutor.s 0 actual sistema conduziu à guerra no Vietname, em que os Estados Uni-
dos estão a sacrificar uma população inteira com a suposta justificação de travar a onda comunista» e a crise do Médio Oriente «em que a Uniāo Soviética encorajou cegamente a hostilidade dos árabes contra Israel.» Pelo contrário, os EUA e a URSS poderiam encetar um programa de colaboração para resolver em con junto os problemas mais graves junto mica, a fome, poluição da água, do ar e do sol.

QUATRO FASES - A grande aliança, de hoje até ao ano 2000 , devia realizar-se em quatro tempos, com uma série de reformas económicas e sociais que eliminassem as contradições mais evidentes entre os dois sistemas, encaminhando-os para um socia- lismo democrático. $\mathrm{Na}$ primeira fase, entre 1968 e 1980 , caberia à Uniāo Soviética retocar a sua estrutura política, criando outros partidos, acelerando o processo de descalinização em todos os níveis, garantindo a liberdade de expressão intelectual com uma le gislação semelhante à aprovada recentemente na Checoslováquia De 1972 a 1985, os Estados Unidos deveriam realizar uma reforma parcial da Economia assegurando à propriedade colectiva e estável uma maior percentagem de instrumentos de pro ducäo Uma legislacāo adequad sobre direitos civis deverin inequivocamente e concretamente oferecer aos negros as mesmas oportunidades que aos brancos. A terceira fase (de 1985 a 1990) veria as duas grandes potências procurar em conjunto a soluçāo do problemas dos países subdesenvol vidos e superpovoados. ét inútil controlar os nascimentos», escreve Sakarov. Um nível de vida mais elevado reduz automàticamente a taxa da nacalidades. Os países ricos poderiam destinar 20 por cento do seu rendimento nacional à assistência económica e técnica -da metade pobre do mundo. 0 quarto escádio, cerca do ano 2000 , seria a do triunfo da liberdade $c$ do progresso. 
"E.U.A e U.R.S.S. lado a lado", que se encontra na seção "Actualidade". Como intencionamos verificar o enfoque dado em textos que tenham a política como centro, mesmo que a matéria não seja aprofundada, é-nos relevante, para entendermos a linha editorial e possíveis marcas que podem denunciar alguma concordância ou discordância relativa ao aspecto político em voga. Baseando-nos nessa delimitação, encontramo-nos com a necessidade de afinar, ainda mais, esse critério, uma vez que na seção "Actualidade" desse número havia três artigos dessa natureza: "Nixon -o candidato do compromisso", que eliminamos, além do motivo de termos outros com teor político mais abrangente, este abordava propriamente as eleições nos Estados Unidos, um fato muito pontual. Os demais tratavam de alguns assuntos, que julgamos pudessem auxiliar no nosso olhar, mais especificamente para a Europa de 1968, continente em que a ebulição do período parecia mais forte, todavia ainda precisávamos delimitar melhor. O segundo texto intitulava-se: "Checoslováquia - A luta prosseguirá no campo econômico", o qual acabamos por eliminar também, além de ser curto e superficial, o que dificultaria nossa análise, apenas mencionava a crise tcheca, em referência ao que ficou mundialmente conhecida como: "A Primavera de Praga". Por fim, nossa opção foi pelo texto: "E.U.A. e U.R.S.S. lado a lado", que muito mais aprofundadamente mencionava a polaridade vivida em plena Guerra Fria.

O texto encontra-se abaixo de uma seção intitulada "Economia". Contudo, apresenta-se muito mais amplo do que os limites do comumente compreensível por Economia, já que é uma ciência que abarca assuntos mais gerais como a política e a própria sociedade. $\mathrm{O}$ artigo vem subdividido em itens: "A notícia”, "Ensaio", "Influências", "Não-conformista", "Dado concreto" e "Quatro fases".

A reportagem não é assinada, dessa forma, assim como o analisado no texto da revista Flama de abril de 1968, presumimos uma mescla entre o sujeito 1, alguém implícito sob a voz da revista, mas também sujeito 2, os jornalistas que produziram o texto, mesmo que não seja nominalmente apresentado. O texto ocupa uma página e traz duas pequenas fotos, uma do governante dos Estados Unidos, Johnson e a outra do governante soviético Breznev. A opção por um texto não assinado impossibilita uma interpretação mais pessoal / subjetiva, em relação aos dois países. 
A organização do texto marca, explicitamente, a divisão do mundo, a partir de dois regimes de governo, o capitalismo e o socialismo. Os recursos lingüísticos, com forte carga semântica, puderam demonstrar, nas entrelinhas, críticas muito mais ferrenhas ao que se vivia na União Soviética. Apenas a título de exemplificação: “(...) pedido que não fosse reabilitado o regime estalinista”; "funestas conseqüências”, “opiniões inconformistas (...) a que o regime jamais abriria as páginas ao Pravda (...)”. Quanto à composição da imagem, apenas as duas pequenas fotos dos dois presidentes, estas poderiam conduzir o leitor à idéia de um diálogo.

No que se refere aos gêneros, de início, encontramos as marcas apropriadas da notícia, em que se fazia menção a um outro gênero textual, escrito por Andrei Sakarov, um ensaio, cujo teor versava sobre uma proposta. No item "Influências", vemos marcas do texto narrativo: “Andrei Dmitriyevich Sakarov nasceu em 1921 e é licenciado em física (...) Desde essa altura tem trabalhado (...) com (...) um dos três cientistas russos que (...) receberam o Prémio Nobel de Física”.

Também como no texto anterior, deparamo-nos com o plano histórico do discurso, verificado especialmente no item "Influências", quando se apresenta o físico. No fragmento, além do esperado uso do pretérito perfeito, encontramos o presente, quando se mencionam as atividades então atuais de Sakarov. O plano discursivo da enunciação, igualmente observado, pôde ser visto em alguns trechos, nos quais o momento da enunciação encontrava-se mais explícito, com e também sem o auxílio de dêiticos, em especial de pessoa e de tempo: "Os dois cientistas foram eleitos para a Academia das Ciências (1953), na sequência das suas investigações sobre o controle da fusão termonuclear”. Como o próprio desse plano de enunciação, o caráter subjetivo é atestado, ao se fazer referência ao que o cientista tinha como proposta.

Já no tocante às vozes encontradas no texto, pudemos constatar, novamente, a voz de um sujeito 1, a voz da revista. A outra voz é do autor da proposta, um sujeito 3, personagem a que se refere a matéria, além de autor do ensaio. Essa voz é "ouvida", em alguns trechos, por intermédio da reprodução literal de suas idéias, por discurso direto.

Andrei Sakarov é apresentado sob a perspectiva de um cidadão russo, mas também este se pronunciou sob a ótica de um catedrático, um físico importante. Ainda sob essa perspectiva de cientista e de catedrático temos, implicitamente, a voz de Igor Tamm e Haris 
Bethe, ambos prêmios Nobel de Física. Apesar de haver essas vozes, oriundas do lugar do meio acadêmico, os dois físicos, assim como Sakarov, não deixaram de falar sob a ótica de simples cidadãos, também. Aliada a essas vozes, mencionou-se uma voz coletiva, que compactuava como os preceitos apresentados pelos cientistas: "a voz corrente nos círculos intelectuais moscovitas".

De forma institucional, encontramos outra vez um sujeito 1, o New York Times, representado pela voz de um órgão da imprensa, bem como o jornal "Pravda", representativo da voz oficial, da voz do poder na URSS. Ainda com referência à imprensa, encontramos a menção à revista "Scientific American", que não deixa de ser a expressão acadêmica de um renomado grupo. Subliminarmente, de algum modo, não se pode negar a existência da voz representativa do regime capitalista. No entanto, é possível inferir isso, na medida em que a voz representativa do regime socialista se fez audível, em oposição ao propagado pelo capitalismo: "Devemos apoiar esta audaciosa iniciativa, fundamental para o futuro da Humanidade e do socialismo (...)”.

O recurso, a nosso ver, para persuadir o leitor quanto à isenção no julgamento de um ou de outro regime político, ficou por conta de o texto não se esquivar de apresentar questões delicadas e não resolvidas nos dois países mais importantes de então: "O actual sistema conduziu à guerra no Vietname, em que os Estados Unidos estão a sacrificar uma população inteira (...) e a crise do Médio Oriente, em que a União Soviética encorajou (...) a hostilidade dos árabes contra Israel". São mais que posturas ideológicas, mas marcas textuais que, muitas vezes, vêem-se como responsáveis para levar o leitor à construção do ethos da revista. Mais uma vez houve a tentativa de convencimento de estar a revista a serviço da democracia e da verdade.

Após esse apanhado geral sobre o texto, passaremos a decompô-lo mais minuciosamente. Para tanto, partiremos no primeiro item, "Notícia", que funciona quase como um tópico frasal, elucidou a que vinha o texto. Para que a proposta não parecesse utópica demais, houve a explicitação de esta ter partido não de uma pessoa comum, mas de alguém com algum saber reconhecido, a ponto de sua referência trazer o substantivo: "cientista". O claro teor de proposta se dá não só pela escolha do tempo verbal, pretérito imperfeito, que traz inserido em sua concepção a idéia de ação interrompida, mas também pelo uso do verbo "dever". A matéria explorou uma proposta feita por um cientista 
soviético, que só via um futuro para o mundo, caso houvesse a união das duas grandes potências.

No item "Ensaio", mencionou-se o texto do cientista, um ensaio, sob o título: "Reflexões sobre o progresso, a coexistência pacífica e a liberdade intelectual", daí o nome da parte seguinte à "notícia". O ensaio tinha sido escrito em 1968, mas não publicado na União Soviética. No trecho, há que se ressaltar o uso ideológico do advérbio "nunca", que indica "em tempo algum". Parece-nos uma utilização exagerada, na medida em que o texto foi escrito em 1968, na URSS e a revista era desse mesmo ano, do mês de agosto.

O advérbio "nunca" é bastante forte e serve para compor o cenário que se tenta demonstrar como o vivido pelas repúblicas que compunham a então União Soviética. O esperado seria o uso de expressões como: "até hoje", "ainda", "até a presente data", por exemplo. Há outro dêitico de tempo, logo na seqüência: "Só agora chegou ao Ocidente". Não nos parece um tempo tão longo assim, ao menos não pelos dados fornecidos pelo texto. Entendemos como uma forma de reforçar a idéia de a União Soviética como um país fechado, não só por certas ações, como por não permitir divulgação de ideologias distintas à apregoada pelo regime vigente, não que esse quadro, de fato, não se mostrasse mesmo com essas cores.

O uso da passiva é verificado em alguns trechos, como recurso repleto de carga semântica. Em: “foi publicado”, essa estrutura pode conduzir como aceitável uma leitura de que em regimes totalitários a publicação de qualquer natureza está à mercê de quem tem o poder para aprovar ou não dada publicação. A publicação ocorre na condição de seu conteúdo sofrer ação de ser aprovada por alguém.

Em: “(...) que têm exportado”, ou seja, a clandestinidade foi responsável pela divulgação de uma literatura crítica em relação à política vigente, que conseguiu atravessar fronteiras. Vemos outro uso sintomático da voz passiva ocorre em “(...) foram eleitos para a Academia de Ciências, em 1953”, como maneira de demonstrar que os cientistas mencionados passaram por um tipo de julgamento, até terem sido considerados relevantes o suficiente, ao ponto de comporem a Academia das Ciências. Já em: “(...) o pedido que não fosse reabilitado o regime estalinista”, há o uso eufemizado do poder do presidente, que tinha como habilitar ou não encaminhamentos políticos apregoados por Stalin, ao menos alguns, ainda seguidos ou na eminência de voltarem no dia a dia da União Soviética. 
As utilizações referidas podem ter a ver com uma estratégia de "ameaça à face" do regime vivido pelo país, ainda reforçada pela menção ao fato de o texto ter extrapolado os grandes limites (geográficos e políticos) da então União das Repúblicas Socialistas Soviéticas, por vias da clandestinidade, responsável pela ação de exportar esse tipo de literatura. Assim, por intermédio de ações que subvertiam a ordem, havia maior probabilidade de opiniões contrárias ao regime não se virem abortadas.

Se por um lado a União Soviética foi mostrada por meio de suas restrições, cerceadora, por outro temos a referência ao "New York Times", uma empresa de comunicação de renome internacional, que conseguiu se firmar como imprensa séria, de credibilidade. A empresa em questão não está instalada em Nova York por acaso, ela é genuinamente americana e os Estados Unidos, nas entrelinhas, sobressaiam-se como um país à frente da União Soviética. O jornal, representativo de uma nação, já de início, por não só ter lido e refletido sobre o ensaio do cientista russo, procurou se mostrar tão imparcial, a ponto de: "traduziu-o na íntegra e publicou-o". Há um discurso subliminar que colocou, mais uma vez, as duas potências de então, de lado distintos, em muitas questões. O que se mostrou, de alguma maneira, em relação ao país soviético, é que em suas sanções ameaçaram a democracia e a liberdade, "própria" do que se propagava ser inerente aos Estados Unidos e, em oposição, ao recrudescido e fechado regime da União Soviética, país gigante, mas que, pelas mãos dos governantes, não cedia espaço ao que poderia ameaçar os dogmas regimentais do partido comunista, que pelo sabido, mantinha-se soberano, graças a sua "mão de ferro" para assegurar o controle do país.

Na parte em que se intitula "Influências", apresentou-se, sinteticamente, a formação acadêmica de Andrei Sakarov. O recurso para elevar Sakarov a um patamar de ainda mais credibilidade atribui-se ao fato de ser um cientista e se explorou sua estreita relação de trabalho e colaboração para com Igor Tamm, "um dos três cientistas russos que, em 1958, receberam o Prémio Nobel de Física”. Essa afirmação corrobora a importância e credibilidade do pesquisador.

Se Sakarov foi corajoso o suficiente para produzir um ensaio sobre a importância de uma eventual aliança entre as duas potências, objetivando a solução de muitos problemas do mundo, muito dessa sua postura pode ter sido amadurecida graças à influência de Tamm, não apenas como físico, daí o item ter esse título. O caráter mais politizado do item 
pode ser verificado no trecho: "Sakarov sofreu profundas influências do mestre, conhecido também, pelas suas corajosas convicções - e posições - de caráter político".

A opção por isolar o substantivo "posições” pode ser entendido como estratégia para ressaltar o posicionamento de Sakarov, um russo, que continuava vivendo na U.R.S.S., sob a égide do totalitário regime soviético. Colocar-se contrário ou crítico a regimes com esse perfil era desafiador e poderia mesmo trazer conseqüências imprevisíveis. Fosse como fosse, ao que parece, Sakarov não se mostrou temeroso.

O item "Não-conformista" apresentou um aspecto de mais afrontamento, de óbvia ameaça à face da política soviética, que foi intensificada por informações do texto, em que se conheceu melhor o posicionamento de Sakarov e suas ações contrárias ao regime stalinista. Para o leitor, o físico apresentou-se, pouco a pouco, refletido por um ethos de um homem que prezava suas convicções mais do que temia as inevitáveis consequiências, sobretudo num país que, para se manter dito unido, não abria espaço para um diálogo entre população e governo, apesar de haver a "capa" de uma "união social" entre as várias repúblicas.

O fato é que as ações de Stalin, a partir de meados da década de vinte, desapontaram muito, em especial as pessoas com maior visibilidade e alcance para analisar o contexto social e político em que estavam inseridos, aliás, bastante diferente do que se pregou em 1917, com a Revolução Russa.

A maneira encontrada pelo autor do texto para intensificar essa postura política do físico ocorreu mais contundentemente no item "Não Conformista", estritamente político, em que se retomou, outra vez, a coragem de mestre e colaborador. A estratégica utilizada foi mencionar que em 1966 Andrei Sakarov e seu mestre, Igor Tamm: “(...) enviaram uma petição a Leonid Breznev (...) no $23^{\circ}$ Congresso do Partido Comunista, não fosse reabilitado o regime estalinista, conforme era voz corrente nos círculos intelectuais moscovitas”. Os físicos não elaboraram o texto de pedido nos moldes do gênero carta, mas de acordo com o gênero petição.

A petição é um gênero de texto mais formal que a carta, é um documento apresentado a um juiz, em que a parte autora alega seus direitos e exige providências. No caso, Breznev, se não era de direito um juiz, poderia agir como um, na prática, já que falava e agia a partir de um espaço instaurador da ordem, das normas, dos deveres. 
O texto não nos oferece pistas referentes a outros intelectuais russos, assim, não podemos dizer que aqueles temessem ou não algum tipo de sanção, entretanto, podemos afirmar isso, no que diz respeito aos físicos mencionados, que não ficaram incógnitos em um documento que poderia não ser assinado. Por outro lado, é provável também que por serem cientistas de renome internacional, sanções a eles ou seriam mais improváveis ou com repercussão negativa, mesmo que passíveis ações de represália não viessem à tona para a sociedade, de forma mais geral. Apesar de estes não se manifestarem do mesmo lugar dos políticos do Kremlin, eram outras vozes autorizadas, pelo reconhecido saber nas ciências.

A matéria seguiu com críticas mais explícitas ao governo soviético, pela voz e pelas ações de Sakarov que, inconformado com muito do contexto a que, de alguma forma, estava submetido, fez-se "ouvir" se não pela própria voz, por meio de seus textos, que não encontravam espaço no "Pravda", jornal oficial da U.R.S.S., mas abriu brechas para fazer circular suas opiniões nos meios científicos e culturais. Talvez pela importância e relevo internacional do autor este não tenha sofrido o que a revista chamou de "funestas conseqüências".

O perfil de uma nação fechada apareceu várias vezes, ao longo do texto. Como a informação pode levar ao conhecimento, o maior acesso a informações poderia conduzir a reflexões, a posicionamentos. Entretanto, os milhões de russos, "acobertados" pelo manto de uma união social tinham acesso às informações, por meio de um órgão da imprensa oficial, o jornal "Pravda". Apesar desse contexto: “Andrei Sakarov tem expressado as suas opiniões inconformistas em artigos e ensaios, a que o regime jamais abria as páginas ao Pravda, mas que nem por isso deixaram de circular dactilografadas, nos meios científicos e culturais da União Soviética (...)”

O trecho acima traz significativas marcas lingüísticas, que ajudam a compor o tom crítico em relação ao que se vivia como realidade de um país mascarado por uma dita igualdade. Inicialmente, a locução verbal "tem expressado", com verbo auxiliar no presente, garante ao fragmento a idéia de ações atuais e constantes por parte de alguém que se via não só descontente, mas mostrava suas opiniões. O adjetivo "inconformista" auxilia na demonstração de descontentamento do cientista. Nesse trecho, há o advérbio "jamais”, que assim como o "nunca", referem-se a um tempo que não só não existe, como não 
existiria. Ou seja, era impensável, tomando por base os dogmas do regime stalinista vigente, abrir espaço para opiniões que não abalizassem o governo. O aspecto de contínua luta por esclarecer sua postura se deu na menção às opiniões inconformistas que aparecem não só em textos do gênero artigo, mas também do gênero ensaio.

Apesar de o texto referir-se pontualmente ao ensaio, mencionou-se ter o físico elaborado textos do gênero artigo. Apenas para elucidar a sensível diferença de ambos os gêneros, já que não entraremos nos limites de sua estrutura, faremos uma breve distinção, ancoradas no Dicionário Houaiss (2001):

Artigo: assunto, ponto, matéria que é objeto de discurso. No jornal, aquele que se discute uma questão, apresentando o ponto de vista do jornal ou do redator-chefe.

Ensaio: prosa livre que versa sobre tema específico, sem esgotá-lo, reunindo dissertações menores, menos definitivas que as de um tratado formal, feito em profundidade. Uma forma de demonstrar conhecimento do cientista, relativo à diferença de cada gênero, bem como seus determinados alcances.

Como as opiniões de Sakarov transcendiam um descontentamento pessoal e subjetivo, estas encontraram brechas alternativas. O que é visto, por exemplo, com o uso do adjetivo "dactilografadas", uma maneira de mostrar que mesmo não contando com a equipe da imprensa oficial, circulavam, em certos círculos, graças a um esforço também físico, no sentido de promover uma adesão, ao menos de seus pares.

O caráter atual do posicionamento de Sakarov pode ser observado quando da menção a seu ensaio: "Reflexões sobre o progresso", em que se colocou frente aos recentes acontecimentos ocorridos na Tchecoslováquia. O cientista viu no episódio o que chamou de “(...) significativas experiências para a definição de uma nova forma política a meio caminho entre o Socialismo e o Capitalismo”.

Para o autor do ensaio, o que se passou em Praga devia ser entendido como um importante movimento, que pedia ou clamava por uma abertura política, na ainda Tchecoslováquia. O que se clamou, segundo o físico, foi um meio termo, um caminho entre o socialismo e o capitalismo. Aliás, era esse o cerne da proposta do físico, pensando numa 
hipotética união entre os dois centros do poder do mundo, daquele momento do contexto da Guerra Fria, no tocante a possíveis ajudas para os países subdesenvolvidos e muito populosos. Essa hipotética união implicava num rompimento em relação ao apregoado pela cabeça do regime, de que faziam parte os países do leste europeu. A essa agitação que ressoava pela U.R.S.S., assim como em alguns países do leste europeu, Sakarov usou o adjetivo "audaciosa", para se referir à iniciativa a que ele julgou ser vital para o futuro da humanidade. Essa parte do texto finda com a frase que mostra mais uma vez o posicionamento claro, crítico e avesso de Andrei Sakarov aos rumos que a Cortina de Ferro persistia em seguir: "Esta posição está longe de coincidir com a dos dirigentes russos (...)".

No item "Dado concreto", a estrutura textual aproxima-se mais de uma notícia sobre a publicação de uma proposta. Como estratégia argumentativa, Sakarov, em seu texto, partiu de um dado concreto: o fato de, naquele momento, o mundo estar dividido e, assim ameaçado de destruição. Daquele prisma, o que se via era a humanidade, além de ameaçada, de mãos atadas, na triste condição de expectadora do que poderia vir a ser o seu próprio fim.

O cientista foi ainda mais explícito, e o trecho ganhou um teor menos figurativo e mais real: "Não há defesa possível (...) contra os mísseis estratégicos e armas nucleares na posse dos russos e dos americanos." Trocando em miúdos, o físico não via mais que duas possibilidades, frente a esse estado de coisas, ou haveria uma destruição, como consequiência dessa divisão do mundo, a partir das duas potências, ou uma chance de não só salvar o mundo da destruição, mas conseguir muito mais que isso, um desenvolvimento global, na condição de uma união entre os EUA e a URSS.

As estratégias para manutenção de credibilidade continuaram, na forma com que Sakarov construiu sua argumentação. Num determinado trecho, recorreu ao que a revista Flama aludiu a um socorro de opinião. Em outras palavras, o cientista buscou um outro nome de reconhecido saber, para mostrar entre eles uma comunhão de posicionamentos. O físico, após fundamentar sua teoria e aludir a uma consonância de pensamentos, passou a expor o que seria preciso fazer, para iniciar um trabalho conjunto entre os dois países. Para tanto, requisitou uma outra voz, a de Haris Bethe, outra pessoa de relevo no meio acadêmico, também Prêmio Nobel de Física, que teve um trabalho “(...) publicado (...) 
revista "Scientific American (...)". A fim de mostrar outro dado concreto de que a U.R.S.S. se mantinha fechada, prosseguiu: “(...) uma revista que não circula oficialmente na União Soviética". A inserção do advérbio de modo "oficialmente" acaba por afirmar, não tão às claras, que de um outro modo, entretanto, publicações variadas circulavam.

Como a estrutura do texto, na parte a seguir, não é muito clara, a passagem: (...) critérios actuais da diplomacia interna, destinada a obter, exclusivamente, "a máxima vantagem para os próprios interessados e o máximo prejuízo para qualquer interlocutor”, que aponta para a ferida aberta dos Estados Unidos, a Guerra do Vietnã, esta não é deixada para trás e tanto poderia ser atribuída à fala do físico Bethe, como a Sakarov. Entendemos essa ambigüidade como um problema estrutural do texto, mais do que um recurso utilizado conscientemente.

O trecho merece cuidadosa atenção. O uso do advérbio de modo "exclusivamente" enfatiza não o compromisso de uma nação para com seu povo, mas de acordo com interesses outros, muitas vezes escusos. Se são escusos, às vezes, na prática, estão claros e evidentes no texto, em que se vê a máxima vantagem dada aos interessados, na mesma proporção em que se dá o máximo prejuízo para qualquer interlocutor, reforçando a questão arbitrária e fechada, tanto dos Estados Unidos como da União Soviética. A crítica ficou acirrada e o olhar severo saiu da Europa do leste e seguiu em direção direta aos Estados Unidos.

O texto ganha o relevo de imparcial, quando a revista pontuou tanto os Estados Unidos como a União Soviética como países pouco preocupados com o direito de autodeterminação e bem-estar de outros povos, já que não limitavam ações bélicas e intervenções em conflitos entre outros países. Para tanto, afirmou-se: “(...) os Estados Unidos estão a sacrificar uma população inteira com a suposta justificativa de travar a onda comunista". O uso do adjetivo "suposta", no contexto, parece uma forma de colocar em xeque a existência de algo, no caso a tal onda comunista, que seria mais um pretexto para as ações dos americanos que qualquer outra coisa. A crítica do autor ganha peso, por não restringir o olhar aos E.U.A. e segue com a crítica do lado da U.R.S.S.: “(...) a União Soviética encorajou cegamente a hostilidade dos árabes contra Israel." O uso do advérbio de modo "cegamente", no trecho, dá-nos idéia de ações impensadas e insufladas, tendo por motivos reais, interesses escusos. O último período do penúltimo item traz a proposta de 
união das grandes potências, tendo por justificativa um bem maior, a vida da humanidade. “(...) os E.U.A. e a U.R.S.S. poderiam encetar um programa de colaboração para resolver em conjunto os problemas mais graves da humanidade: a ameaça atômica, a fome, poluição da água, do ar e do sol”. Para enfatizar que as ações nessa direção deveriam vir de ambos os lados, houve o cuidado do autor da proposta em salientar, com a expressão: "em conjunto", a imprescindível união das grandes potências.

$\mathrm{Na}$ seqüência da exposição sintética do conteúdo do ensaio, a Flama mostrou como poderia ser possível um programa, de acordo com a idéia de Sakarov, encabeçado pelas duas potências, para dar conta de "resolver os problemas mais graves da humanidade: a ameaça atômica, a fome, poluição da água, do ar e do sol”. (Aliás, ameaça que persiste e após quarenta anos continua na eminência de ocorrer).

O item "Quatro fases", parte final do texto, fica por conta do plano delimitado, da maneira como esse plano de ajuda humanitária poderia ser exeqüível. Houve a utilização dos verbos no futuro do pretérito, como forma de refletir na condicional união entre as duas potências, a fim de se executar um plano de ajuda humanitária.

O fato colocado como primeiro passo a ser dado era uma ação que o autor chamou de “destalinização da União Soviética, em todos os níveis”, o que nos faz pensar que, talvez, visse no quadro mundial como o problema mais grave a ser resolvido. Um problema cujo caminho para solução havia sido aberto com a prerrogativa dos acontecimentos da chamada "Primavera de Praga".

Em termos lingüísticos, o uso do substantivo "triunfo", no último período do texto simboliza uma esperança que estava nas mãos de dois homens, os presidentes dos Estados Unidos, Lindon Johnson e o presidente da União Soviética, Leonid Breznev, que aparecem em duas pequenas fotos, apenas com seus respectivos nomes e, sob estes, uma pergunta: “Mãos dadas para o progresso?”, o que poderia ser lido como um descrédito, já que para essa união um necessário despojamento por parte dos dois líderes seria imprescindível.

Esse último item do texto fica por conta de um possível cronograma da aliança entre E.U.A. e U.R.S.S., que começaria já no próprio ano de 1968 e estaria concluído em 2000, ocorrendo em quatro fases. A revista utilizou algumas marcas lingüísticas fortes no trecho, como o verbo "eliminar", referindo-se às contradições dos dois sistemas, o socialismo e o capitalismo. Nesse trecho, vemos outra vez a crítica ao sistema fechado e que já não podia 
se sustentar e usou-se como exemplo de caminho para a liberdade, o ocorrido em Praga e que resultou ganhos reais: “(...) caberia à União Soviética retocar a sua estrutura política, criando outros partidos, acelerando o processo de destalinização, garantindo a liberdade (...), com uma legislação semelhante à aprovada recentemente na Checoslováquia”

A opinião do autor era favorável a um sistema socialista democrático. Talvez, de alguma forma, acreditasse estar a U.R.S.S. um pouco mais no caminho para isso. Mesmo tendo imaginado o início da execução de sua proposta pela destalinização de seu país. É uma suposição, tendo em vista o uso do verbo "retocar", ou seja, a partir do que já se tem, fazer certos ajustes. A fase seguinte caberia ações dos E.U.A., mais especificamente no campo econômico, promovendo uma maior estabilidade, além de uma flexibilização na legislação sobre os direitos civis, em que brancos e negros tivessem as mesmas oportunidades. A terceira fase ficaria a cargo das duas superpotências, que teriam a difícil tarefa de buscar soluções para os países subdesenvolvidos e superpovoados. Finalmente, a última fase, no ano 2000, em que haveria o triunfo da liberdade e progresso, como consequiência da execução dos planos nas fases anteriores.

A reportagem é metalingüística, na medida em que se constrói não só em referência de um outro texto, mas especialmente, para noticiar sua divulgação, bem como apresentar seu autor. Tomando por base não propriamente o texto apresentado pela revista, mas considerando o teor do ensaio de Sakarov, concluímos o texto como contundente, levandose em conta a ideologia. Ao longo da reportagem, são várias as referências da ideologia dita socialista, presumidamente instaurada pela URSS e, por outro lado, a ideologia capitalista da parte dos EUA, nenhuma das quais, na prática, parecia menos cruel. O posicionamento ideológico de Sakarov não é só claro, como explicitado ao longo do texto. O autor do texto proposta, detentor dos caminhos adequados para a estruturação de uma tese, presumidamente deve ter seguido os passos desses encaminhamentos, a fim de argumentar eficazmente e, para tanto, lançou mão de recursos próprios da construção de um discurso dessa natureza, da construção própria da tipologia argumentativa, com enquadramento científico, técnico.

No texto da Flama, relativo ao ensaio, os recursos estruturais vão desde a conclamação de pessoas de reconhecido saber, como a um posicionamento de um físico, respaldado por 
um mote, uma reflexão e, em seguida, isso convergiu em propostas, para que o autor russo entendia como forma de salvar a humanidade. 


\subsubsection{Flama número 1072, ano XX V, de 20 de setembro de 1968.}

$\mathrm{Na}$ capa há três fotografias, sendo duas pequenas, com as respectivas manchetes: "Soraya disse não à festa Patiño" e "Richard Nixon: quem é o candidato republicano à

presidência dos Estados Unidos". Estas ocupam quase metade da capa. À outra parte, a maior, há a fotografia de um casal e traz a manchete: "Em exclusivo: As fotos da noiva de Amadeu dos Anjos". Entre as fotos pequenas e a grande há outra manchete: "Tudo sobre o ciclo preparatório do Ensino Secundário”.

Esse último exemplar de Flama a ser analisado apresenta, no sumário, as seguintes seções: "Especial", em que se encontra a "Entrevista com o único europeu de "coração novo"; "Exclusivo", que conta com a reportagem sobre Richard Nixon, o casamento de Amadeu dos Anjos e a matéria sobre Soraya, ex-imperatriz do Irã; "Actualidade", cujo subtítulo da seção, "Em foco", traz notícias nacionais e internacionais, num total de cinco. Uma com informações sobre o Congo e os problemas pelos quais passava no momento; um texto sobre plantações ilegais de uva; outra reportagem sobre o mercado negro na Checoslováquia; um texto sobre conflitos em Biafra, na África e um último acerca de governantes comunistas, Tito e Ceausescu e uma pequena parte de uma das páginas com o título "telegramas", destinados a pequenas e variadas notas de fatos recentes.

A seção "Reportagem" conta com oito itens, que vão de uma festa no Zambujal, segue para a questão do ciclo preparatório, um texto sobre automóveis japoneses; um artigo sobre as hospedeiras de Portugal; um outro que traz informações sobre a localidade Olivais; um pequeno artigo, com muitas fotos, sobre a doença de Salazar; ainda uma reportagem com um famoso pintor do Porto, Henrique Moreira e finaliza com uma matéria sobre um terremoto na Pérsia.

Cabe uma ressalva sobre um item da seção "Reportagem", em virtude de sua superficialidade. Trata-se de um artigo extremamente curto, com apenas duas páginas, contendo quatro fotos, relativamente grandes, com os devidos créditos, e um texto verbal construído com apenas um parágrafo, em que se menciona o fato de Salazar continuar internado na Casa de Saúde Santo António da Convalescença. Tinha sido operado de emergência: "a um hematoma subdural intercraniano, originado, ao que se afirma 
oficialmente, por uma queda fortuita na sua residência de verão”, no Estoril, há pouco mais de um mês. Partiu-se para a finalização do texto, com referência aos médicos responsáveis e com a informação de que no último domingo o presidente do conselho, Antonio Salazar tinha recebido a visita do presidente da república.

Em duas das fotos, vemos o presidente da república conversando com os médicos, uma outra em que vemos muitos jornalistas, a fim de cobrirem o estado de saúde do político, além da outro foto, cujo destaque é a senhora Maria de Jesus, governanta há longos anos de Salazar. Além de a reportagem ser superficial, com fotos que registram apenas pessoas em busca de informações sobre o estado de saúde de Salazar, há uma certa dúvida colocada, se o que se tinha conhecimento do ocorrido era, de fato, a realidade. Essa dúvida não explícita pode ser verificada em: “ao que se afirma oficialmente”. O instigante é o restrito espaço destinado a notícias sobre um homem que esteve à frente de Portugal por décadas.

Na seqüência da divisão da revista, há a seção "Desporto", que traz um texto sobre o futebol; a seção "Crônicas", com temas relativos ao cinema, touros, livros e artes plásticas; a seção "Rubricas", que conta com "Flash da semana", "Cartas ao Director", programação da TV, menção a alguns discos, os tradicionais passatempos, como humor, palavras cruzadas, fotografia dos filhos, além da página "Crocodilo" e a última seção "Da mulher", em que se explora moda e maquiagem. Ao lado do sumário, há uma foto de Nixon e um pequeno texto, com a menção à proximidade das eleições nos Estados Unidos.

Novamente procedendo ao critério de seleção de um texto de cunho mais político, outra vez não escolhemos a reportagem sobre Nixon, pelo mesmo motivo, ser esta muito mais uma apresentação do candidato mais cotado para governar os Estados Unidos e por ter como pano de fundo um acontecimento pontual: as eleições na Casa Branca, em novembro de 1968. Na seção "Actualidade", havia mais opções e para delimitar nossa análise, achamos que os textos relativos à África, como não dizia respeito direto à Europa de forma geral, nem a Portugal de forma específica, já que não eram textos sobre as colônias portuguesas, não eram tão representativos, tendo em vista seguirmos um dado recorte.

Por fim, sobraram mais dois textos possíveis. Excluímos o "Checoslováquia- Mercado Negro: uma ofensa”, por este apresentar um teor, ainda que político, mas mais focado no desenvolvimento econômico, por via do mercado negro. Aliado a isso, o outro texto, "Tito e Ceausescu unidos no perigo”, além de conter muito mais subsídios férteis para análise, era 
essencialmente político e voltou a tratar do importante movimento vivido em Praga, já mencionado em outro texto, na revista Flama, de 23 agosto de 1968.

Principiamos a exploração dos textos desse número da Flama com a reportagem central da capa, assinada por Manuel Vieira, presente na seção "Exclusivo", que no sumário se apresenta como: "Amadeu dos Anjos: casamento" e que nas duas páginas destinadas à matéria temos por manchete: "Amadeu dos Anjos - o amor colheu o toureiro". A reportagem ocupa três páginas, das quais são fartamente constituídas por fotos, num total de cinco. Em três delas temos o toureiro e sua noiva, uma outra em que Amadeu dos Anjos se encontra ao lado do "apoderado" Fernando Camacho e uma última, em que o toureiro se encontra em plena arena de touros, recebendo flores de um menino.

Como característica da Flama, mais uma vez o destaque da capa é uma pessoa de renome na sociedade e a reportagem conta um pouco de sua vida privada e traz uma descrição de quem foi a eleita do toureiro. Ainda como marca da revista, aliás o bastante visto em publicações do gênero, há forte apelo da imagem.

O texto inicia com o uso da primeira pessoa do singular, em que o jornalista fez uma descrição de como, pessoalmente, via Amadeu dos Anjos, uma pessoa boa, simples, que não dava valor a adulações. O prosseguimento do texto se faz após o subtítulo: "Na capital sê marçano", em que se contou um pouco da origem humilde do toureiro, o início da vida como simples trabalhador, em Lisboa até começar a se interessar pelos touros. O texto apresenta outro subtítulo: “Bondosa, honesta, dona-de-casa”, em que há uma guinada e o foco do jornalista passou a ser a noiva do toureiro.

Com esse subtítulo, composto por adjetivos para qualificar positivamente a escolhida de Amadeu dos Anjos, temos claro o ideal de mulher até então como modelo, apesar das "revoluções" feministas que começavam a "pipocar" em vários países do Ocidente. Como a revista tinha uma forte ligação com a Igreja, a linha editorial não podia ser muito distinta desse caminho e, assim, como o visto em outras tantas publicações a que Brasão (2006) se refere como revista de sociedade, a família merece imprescindível destaque e uma boa mulher, uma dona de casa é a base da família.

Apesar de oficialmente ainda o casal não figurar como família, estavam prestes a constituir uma. Nessa parte do texto, o jornalista, para demonstrar a proximidade com o toureiro, próprio de quem está numa situação de entrevista, deu voz ao entrevistado, 
verificável pelo uso do discurso direto. São várias frases do toureiro para descrever sua noiva, bem como a fase feliz vivida, a qual estavam tendo.

O uso da primeira pessoa do singular segue nessa parte final da matéria, para relatar uma atuação desastrosa do toureiro, o que o levou a ficar fora das arenas por dois meses e infeliz. No trecho, o jornalista usou os verbos no pretérito perfeito. Continuou, no entanto, o relato no presente, para demonstrar a mudança de estado de espírito de Amadeu dos Anjos: "Vejo-o hoje feliz". O jornalista voltou a narrar um outro dia de corrida de touros e o repórter deu prosseguimento com a utilização dos verbos no presente e passou a descrever a atenção e a preocupação com que Elsa assistia aos espetáculos de tourada. A intervenção do jornalista, a fim de melhor construir o ethos da moça, como modelo de companheirismo, dedicação e fé, torna-se a visível em: "Se Amadeu é colhido, nos lábios da jovem nasce uma prece e as mãos juntam-se a fortalecer a oração”. O fechamento do texto ficou por conta da tensão criada pelo trecho: “(...) Amadeu dos Anjos (...) desce às arenas, vestido de oiro, para matar ou morrer". É o ethos do herói que nada teme.

Para finalizar as análises das revistas portuguesas, passamos ao texto da seção “Actualidade", no item "Em foco", cujo título é: "Tito e Ceaucescu unidos no perigo". 
- Por portaria publicada no aDiório do Governos vão ser abertamente, de Angola e Mosambique.

Joseph Whelan: «Na minh diocese havia cinquenta homens. Desses, vinte e cinco já fugiram para o Norte, e os ou tros vinte e cinco continuam a comer da mesma gamela. Mas os que se refugiaram na selva nem sequer uma gamela têm». As experiências de terror por que têm passado, empurram os biafrènses para acçōes desesperadas, sem medirem as consequências. A esta hora, muitos dos vinte e cinco refugiados de que falou o bispo dos de Whelan estarão já mortos. «Eu e os meus padres - prossegue o bispo - vimo-nos incapacitados de distribuir alimen tos aos fugitivos. Não temos para nós, sequer».

\section{MERCENARIOS BRANCOS -} Enquanto 0 povo ibo morre pelas armas ou pela fome, que faz a meia-dúzia de mercenários brancos que constituem a maior força do exército biafrense? «Lutarei até poder declarou o rodesiano John Erasmus, de 26 anos de idade, e um veterano nestas questöes de mercenários - e depois se verá».

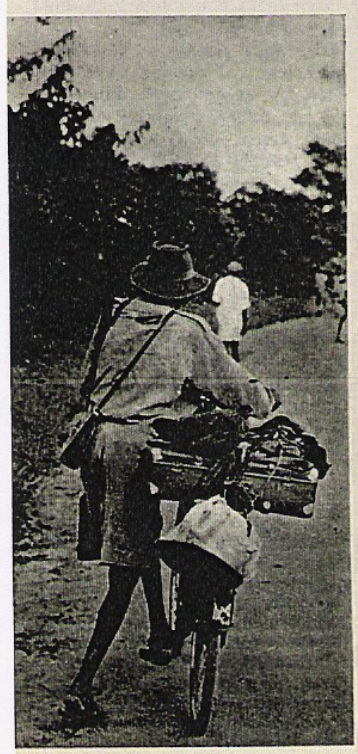
RUMO A SELVA - Unica saida.

COMUNISMO

\section{Tito e Ceausescu unidos no perigo}

A NOTIClA - Face à invasão armada da Checoslováquia pelas forças da U. R. S. S., tanto o marechal Tito como o primeiro-ministro Ceausescu (da Jugoslávia e da Roménia, os dois países que, com a Checoslováquia, constituiam o triângulo kherético» do campo socialista) temendo idêntica medida em relação aos seus países, foram unânimes em reafirmar a sua decisão de lucar pela independência, se tal se tornar necessário.

VIOLAÇAO DA SOBERANIA - A intervenção militar soviética em Praga é uma violação da soberania de uma nação socialista independente, não justificável pelo pacto de Varsóvia, que é apelo pacto de Varsóvia, que é ape-
nas um instrumento de defesa nas um instrumento de defesa listas». As opiniōes da Jugoslávia e da Roménia àcerca dos acontecimentos de Praga coincidiram tanto no conteúdo como na forma. Os dois paises encararam os recentes acontecimentos como o recentes acontecimentos como episódio de uma longa guerra-fria com Moscovo, e, pe rante a ameaça de agressão sovié tica às suas fronteiras, encontraram uma rápida e decisiva unanimidade.

UMA BANDEIRA MANCHA DA - A quatro dias da entrada dos tanques russos em Praga, marechal Tito e o primeiro-ministro romeno Nicolas Ceausescu encontraram-se em Vrsak, uma cidadezinha jugoslava na fronteira entre os dois paises. $\Lambda$ mudança entre os dois paises. $A$ mudança
de perspectiva deve ter sido pede perspectiva deve ter sido penosa, a julgar pelo tom da última que se mantenha o sangue frio, mas devemos fazer saber que se, um dia, uma ameaça de qualquer género pesar sobre a nossa independência, saberemos defendê-la com todos os meios».

Em 1948, foi afastada a mancha que ameaçava a bandeira vermetha do proletariado. A mancha reapareceu, mas torna-se muito mais difícil afastá-la de novo *Nos dias que se seguiram, os dois paises entraram em clima de mobilizaçāo.

Para além da polémica, porém, quais são as verdadeiras relaçōes entre os dois ex-estalinistas e a mãe-Rússia? E que coisas existem de comum na posição dos dois países - um dos quais, a Roménia, ainda é membro do pacto de Varsóvia, e o outro, ainda que Comunista, vive na aheresia» há já 20 anos?

IDENTICA CRISE, EM 1948 O jornal \&olitika», de Belgrado, recordou que idênticos momentos de crise e um ataque contra a Jugoslávia tiveram lugar em Junho de 1948, quando Tito fo cexcomungado». Em seguida, $\mathrm{Ni}$ kita Kruchtchev veio a Belgrado e os dirigentes soviéticos reconciliaram tudo. $O$ jornal reproduziu na integra as célebres «Declarana integra as célebres «Declaraçōes» de Belgrado (1955) e Moscovo (1956) nas quais os princiigualdade entre os movimentos comunistas civeram um formal apoio da parte dos soviéticos. A

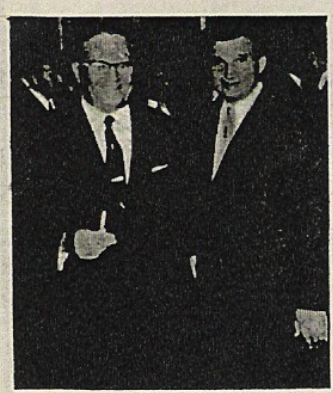

TITO E CEAUSESCU encontro de emergóncio. partir de então, Belgrado acentuou a distância em relação ao bloco comunista. Liberalizou parcialmente a sua economia, multiplicando as relaçōes e as trocas com o Ocidente. Em 1967, o Mercado Comum absorveu 31 por cento da exportação jugoslava forneceu 40 por cento das importaçōes.

O processo de liberalização im posto por Tito encontrou resistên cia da parte da velha-guarda conservadora e da nova burocracia estatal, mas é lento e incompleto aos olhos dos intelectuais, da va esquerda» e das organizaçōes estudantis universitárias.

Ora a crise checoslovaca forneceu ao marechal Tito toda a força que o impeliu para uma completa democratizaçäo das estruturas do partido para uma economia liberta de condicionalismos políticos.

DESAGREGAÇAOO PROGRESSIVA - A situação da Roménia muito diferente. A progressiva separaçāo da Uniāo Soviética, que os romenos realizaram nos últimos sete anos, não levou à saida da Roménia do pacto de Varsóvia nem a uma diminuição da influência económica da Rússia (com a qual se realiza ainda 65 por cento do intercâmbio comercial romeno). A industrializaçāo forçada (com um indice de desenvolvimento anual de 13 a 14 por cento) não significa ainda que a Roménia possa bastar-se a si própria Além disso, dentro dos propria Alem disso, dentro dos aspectos mais sensacionais da edesrussificaçáo», a estrutura poder permanece centralizada.

O partido comunista romeno é mais autoricário e ortodoxo que o checoslovaco e até que o jugos. lavo.

Nicolas Ceausescu, herói da imprensa moderada ocidental dirige o seu país com punho de ferro, sem fazer quaisquer concessōes à direcção colegial que se pratica a Rúcsia ḱ por esta razão que a Uniäo Soviécica não conduriu Un énia até uma intervençäo directa pelas ar-
mas.

Nas suas tentativas de desligação económica e até política da União Soviética (na perspectiva de uma liga balcânica com a Jugoslávia e a Checoslováquia), $\mathrm{Ni}$ colas Ceausescu encontrou um imprevisível aliado: a China, através de Chu-en-Lai, que ofereceu auxílio militar e até talvez ajuda económica à Roménia 
O texto é apresentado em uma única página e vem subdividido em cinco partes: “ $A$ Notícia”, "Violação da Soberania”, “Uma bandeira manchada”, "Idêntica crise em 1948” $e$ “Desagregação Progressiva”. Há apenas uma pequena foto, em que os presidentes, da Iugoslávia e da Romênia estão juntos, sorrindo. Pelo estudo em Hernandes (2006), essa foto também pode ser identificada como de registro foto de registro, ou seja, aquela que mais se aproxima de uma ancoragem para o texto. Há que salientar, todavia, a expressão cordial e o sorriso de ambos presidentes, uma forma de demonstrar algum tipo de parceria, união. Abaixo do crédito da foto, o qual somente menciona as pessoas retratadas, Tito e Ceausescu, lê-se "encontro de emergência".

Conforme o verificado nos três números da revista Flama, os textos retirados da seção "Actualidade", do item "Em foco", apresentam-se sem assinatura e, pela estruturação, é, como já observado antes, a representação do que Hernandes (2006) chama de sujeito 1, ou seja, o próprio meio de comunicação, no caso, a revista Flama.

A estratégia para manter o apagamento de um eu muito subjetivo é o pretendido, ainda mais em uma seção, cujo teor de muitos assuntos é o político. O explicitamento político, como também ideológico, pode trazer consequiências nefastas para um órgão de imprensa, quer advinda do que podemos recuperar com Althusser (1970) que representam os aparelhos ideológicos ou os aparelhos repressivos do estado, como conseqüência no tocante à perda de público, incompatível com os objetivos de uma empresa, dentro da lógica capitalista.

Quanto aos gêneros do discurso, observamos o predomínio do relato acerca de fatos recentes, bem como o gênero notícia, ao trazer informações de providências e articulações de dois países, a fim de se fortalecerem para não cederem a um iminente agravamento da crise.

Em "Tito e Ceausescu unidos no perigo" também, como nos textos anteriores, vimos dois planos de enunciação, o histórico e o discursivo. Nos trechos elaborados com o fito de compor um contexto histórico, as marcas de referência à enunciação não são comumente verificadas. É uma estrutura em que se privilegia o tempo da história, um momento já transcorrido: “A quatro dias da entrada dos tanques russos em Praga, o marechal Tito e o primeiro-ministro romeno Nicolas Ceausescu encontraram-se em Vrsak (.. )”. Assim, o 
mais observado são os verbos no pretérito perfeito, no caso específico do presente texto. O outro plano de enunciação, o discursivo, pode ser comprovado, em especial, nas passagens em que se reproduz a fala dos dois governantes, identificados como sujeitos 3 , ou seja, os personagens da matéria: “É necessário que se mantenha o sangue frio (...)”. Para tanto, o tempo verbal mais aplicado é o presente, uma forma de demonstrar o fato em questão, como atual.

Deparamo-nos, no que se refere às vozes do texto, com os presidentes Tito e Ceasusescu, ambos falaram sob a perspectiva de governantes, mas com a particularidade de se mostrarem insatisfeitos com algumas ações comandadas pelo poder central do regime soviético. A voz de Tito foi explicitada, por meio do discurso direto, no item "Um bandeira Manchada”: "É necessário que se mantenha o sangue frio, mas devemos fazer saber que se, um dia, uma ameaça de qualquer gênero pesar sobre a nossa independência, saberemos defendê-la com todos os meios." A afirmação pode ser vista como uma préameaça, caso vissem seus países sob alvos de novas invasões, como a de Praga. A utilização da primeira pessoa do plural auxilia a demonstrar um peso maior na advertência, uma vez que não seria uma ação ou uma resistência isolada. Aliado a isso, o uso da locução verbal "fazer saber" é nitidamente o envio do recado que queriam os dois governantes dar.

Ainda nessa parte do texto, há o uso das aspas para reproduzir um outro discurso direto, alguns questionamentos: “(...) quais são as verdadeiras relações entre os dois exestalinistas e a mãe-Rússia?","(...) que coisas existem de comum na posição dos dois países (...)?”, entretanto não existem marcas explícitas de quem os proferiu. A nosso ver, são perguntas levantas pelo próprio sujeito 2, ou seja, profissionais que, em nome da empresa que representam, dão voz à revista. Essa voz, que é a voz da Flama, é vista de forma predominante e distribuída ao longo de toda a matéria. Encontramos, ainda, um sujeito 1, o jornal "Politika", de Belgrado. Já com o status de sujeito 3, os personagens, mas também sob uma ótica de poder, encontramos os dirigentes soviéticos, não identificados nominalmente, mas que tiveram o poder de reconciliar "tudo". A reconciliação tinha a ver com os problemas entre o presidente da Iugoslávia e o alto comando soviético.

As vozes detectadas, unidas, propiciaram que o leitor, em quase sua totalidade indivíduos ocidentais, que olhassem, mesmo de fora, e compreendessem a insatisfação de muitas pessoas, de diferentes países do bloco socialista, alinhados à União Soviética. A 
partir dessa constatação, o esperado é uma construção do ethos do regime como arbitrário, opressor e que, na prática, não promovia a tal apregoada igualdade.

Quanto à organização global do texto, no tocante a seu conteúdo, temos indícios explícitos de descontentamento de alguns países que compunham a chamada "Cortina de Ferro". Esse descontentamento se deu num crescente e, se trouxe conseqüências materializadas até um passado mais recente, movimentos isolados ou não tão isolados assim passaram a ser freqüentes, em especial após a Primavera de Praga. Em suma, o possível de detectarmos foi a busca de uma abertura política. Com isso, o domínio soviético mostrava-se dividido, a ponto de se vir ameaçado mesmo dentro dos limites geográficos de sua área de influência política. Após uma prévia sobre o texto, passaremos a uma análise mais detida, segundo a seqüência com que a matéria foi produzida.

No item “A Notícia”, como o já verificado antes, há uma síntese do que será abordado. No caso, a aliança entre a Iugoslávia e a Romênia, principalmente em virtude da então recente invasão das forças armadas soviéticas, na Tchecoslováquia. Esse evento, de grandes proporções, ocupou os noticiários do mundo por vários meses e ficou imortalizado pelo poético nome de "A Primavera de Praga". Um nome carregado de força semântica, em especial pelo sentido possivelmente pretendido com o substantivo "primavera", muito mais ideológico do que um referente apenas temporal. É uma estação do ano, período em que a natureza mostra sua força, por meio da fecundidade, brotam-se plantas, frutos, é quando há o desabrochar de muitas espécies vegetais.

Primavera, conotativamente, é tida, até de certa maneira desgastada, como um período que antecede algo muito importante, normalmente uma situação, um momento bom e bastante aguardado. Para além de o evento em Praga ter ocorrido mesmo na estação, aconteceu em maio, primavera no hemisfério norte, representava um passo adiante, um movimento deflagrado, com intuito claro de independência em relação aos fortes limites impostos pelo alto comando da "cortina de ferro". Em reação a esse fato político, travou-se um compromisso mútuo dos referidos dois países, a fim de reafirmar a luta pela independência.

O item "Violação da Soberania" inicia-se com o discurso direto, do dito pelos dois governantes dos países acima mencionados: “A intervenção militar soviética em Praga é uma violação da soberania de uma nação socialista independente, não justificável pelo 
pacto de Varsóvia (...)”. Contudo não se esclarece se a frase foi proferida por Tito ou por Ceausescu. Vemos aí um simulacro da fala literal, ou uma reprodução de um discurso que de improviso nada apresentava. Para essa referência, usou-se o tempo verbal no presente, característico do plano discursivo da enunciação. Todavia, viu-se, também, no item, o tempo pretérito perfeito, como se pode exemplificar em: "encararam”.

Para demonstrar a união dos dois países contra a arbitrariedade vinda de Moscou, temos: “(...) perante a ameaça de agressão soviética às suas fronteiras, encontramos uma rápida e decisiva unanimidade”. A reportagem, graças à materialização lingüística perceptível pela escolha de certas classes de palavras, promove uma interpretação que ultrapassa o que se compreende por uma simples união.

Se "decisiva" corrobora atitudes oposicionistas claras, o adjetivo "rápida" possibilita a leitura de governos dinâmicos e prontos para defender o bem maior, a independência. O trecho é ainda mais contundente, pelo fechamento com o uso do substantivo abstrato "unanimidade", mas que no contexto proporciona mostrar um posicionamento concreto de não aceitação ao imposto por Moscou.

Para expressar o descontentamento dos governantes dos dois países acima citados, quanto à invasão à Tchecoslováquia, temos: "Os dois países encaram os recentes acontecimentos como o último episódio de uma longa guerra-fria com Moscovo (...)”. A expressão "guerra-fria" é um termo criado como referência a um período de forte tensão, sob ameaça de uma terceira guerra mundial, envolvendo especificamente as duas grandes potências de então, os Estados Unidos e a União Soviética. Não parece que seja adequado o uso da expressão para se referir à tensão entre os países do leste, que faziam parte do Pacto de Varsóvia e a União Soviética. Essa utilização pode ser vista como ideológica, ainda mais em textos a serviço de uma ou de outra revista. A menos que levemos em conta um recurso semântico, cujo efeito de sentido é mostrar a forte tensão quase no mesmo nível da vivida entre as duas grandes potências e países do leste europeu.

"Uma bandeira manchada", esse é o subtítulo da terceira parte da reportagem, em que se relata um encontro entre os dois governantes, a fim de se discutir a séria crise política que havia se abatido sobre os países que compunham o bloco socialista, dias antes de a Tchecoslováquia ser invadida. Como o que estava em causa era a certa (e até questionável) soberania, cabia aos dois líderes uma manifestação quanto aos episódios e prováveis 
repercussões em suas repúblicas. A revista reproduziu, como já apresentado antes, em discurso direto, o afirmado por Tito. Logo na seqüência da fala do presidente da Iugoslávia, lemos: "Em 1948, foi afastada a mancha que ameaçava a bandeira vermelha do proletariado. A mancha reaparece, mas torna-se muito mais difícil afastá-la de novo”. Podemos ler essa mancha em comparação com as ações soviéticas, sujas, como manchas. A voz passiva verificada aí é uma forma de não explicitar os responsáveis pela ação de afastar a tal mancha.

O uso da conjunção coordenativa "mas", que tem por função prioritária expor uma oposição de idéias, uma atenuação ou ainda contradizer algo, é utilizada, em algumas passagens, ao longo do artigo. Na segunda utilização, no trecho acima reproduzido, o "mas" traz o efeito de sentido de descrença quanto a uma reação ao que a Flama chamou de mancha que ameaçava o proletariado, dadas às maiores dificuldades de conter os avanços da força armada russa.

No trecho, encontramos o plano histórico da enunciação. Há referências a episódios pontuais, uma maneira de relatar o momento mencionado. Nesse caso, o uso prioritário foi o do verbo no pretérito perfeito. Porém, vemos também marcas do plano discursivo da enunciação. Nessa situação, percebemos o uso do verbo no presente, como o visto na fala do presidente Tito. O fragmento traz forte carga subjetiva, passível de ser observada mais claramente nesse plano discursivo da enunciação, em que se destaca o momento em que são produzidos os discursos e suas condições de produção, além do lugar, da perspectiva discursiva de quem o proferiu.

Em: “(...) quais são as verdadeiras relações entre os dois ex-estalinistas e a mãeRússia?”, $a$ opção pelo substantivo "mãe” é sintomático para simbolizar aquela que provê, a que educa e ensina e a quem se deve obediência e alguma devoção.

No item "Idêntica crise, em 1948", deparamo-nos, por intermédio do sujeito 1, com uma leitura ideológica em relação ao jornal "Politika", um órgão da imprensa iugoslava, pretensamente isenta, imparcial, tanto que: "O jornal reproduziu na íntegra as célebres “Declarações” de Belgrado (1955) e Moscovo (1956) nos quais os princípios da nãointervenção e da igualdade entre os movimentos comunistas tinham um formal apoio da parte soviética”. Se a leitura se mostrou ideológica, fazer referência a esse órgão da imprensa também não deixa de o ser, uma vez que o Politika retomou a crise de vinte anos 
antes, a de 1948, além de ter defendido a liberalização da economia e o distanciamento da União Soviética.

O título do trecho justifica-se pelo fato de a revista recorrer ao plano histórico da enunciação, para relatar um outro momento da crise soviética, já de décadas: “(...) quando Tito foi "excomungado", reforçado pelo adjetivo "excomungado" entre aspas, que demonstra seu uso conotativo, uma vez que, denotativamente, é utilizado para designar aquele que não segue os preceitos da Igreja é excluído dela. Tito foi execrado pelo poder supremo do regime soviético e, mesmo assim, manteve-se no poder. Isso graças à “indulgência” de: “(...) os dirigentes soviéticos reconciliaram tudo”. Subliminarmente, houve algum reconhecimento ao crescimento, à importância do avanço do liberalismo. O trecho segue com um relato em que se justifica a causa de a Iugoslávia ter vindo, há anos, aos poucos, distanciando-se: "em relação ao bloco comunista".

Desse posicionamento corajoso de Tito, a Iugoslávia, segundo o apresentado pela revista, teve um crescimento econômico, promovido pelas relações com o Ocidente. O fragmento: "O processo de liberalização imposto por Tito encontrou resistência da parte da velha-guarda conservadora e da nova burocracia estatal, mas é lento e incompleto aos olhos dos intelectuais (...), merece detida atenção. O uso do substantivo composto "velhaguarda" é bastante explícito para designar as pessoas pró regime soviético, desde a revolução ou há já muito tempo. Há um atenuante ao grupo dito "velha-guarda", pela estrutura do texto da revista, com o uso do adjetivo "nova", anteposto ao substantivo "burocracia", que apresenta outro adjetivo, "estatal". Entretanto, ambos compartilhavam de uma mesma visão política.

Na seqüência, vemos o uso da conjunção coordenativa “mas", que é retórico, já que não há uma contradição ou oposição real de idéias e sim uma maneira de reforçar que o regime, de novo, talvez pouco tivesse e que contava, ainda, com o peso da lentidão e da incompletude, no que se referia a ações, na prática.

Como último item, temos: "Desagregação progressiva". O trecho traz o primeiro período com o verbo no presente, para mostrar a situação da Romênia, bastante diferente da bem mais desenvolvida Iugoslávia. Em seguida, passou-se ao plano histórico da enunciação, com verbos predominantemente no pretérito perfeito, para demonstrar os motivos de a Romênia permanecer tão isolada, pobre e dependente da economia da Rússia. 
Se as críticas discretas feitas pela revista ao regime soviético são possíveis de se verificar em muitos trechos, neste último há uma estratégia interessante. O uso de um neologismo. “(...) dentro dos aspectos mais sensacionais da“desrussificação”, a estrutura do poder permanece centralizada."

Implicitamente, de algum modo, podemos ler no fragmento a seguir como uma justificativa para a Romênia continuar no atraso em que se encontrava, tudo por se mostrar mais ao lado e/ou submissa ao "prescrito" pela "mãe-Rússia": "O partido comunista romeno é mais autoritário e ortodoxo que o checoslovaco e até que o jugoslavo."

Por outro lado, o artigo trouxe a informação que poderia contradizer o afirmado antes: "Nicolas Ceausescu herói da imprensa moderada ocidental dirige o seu país com punho de ferro (...)”. Herói talvez pelo fato de que a dita imprensa moderada ocidental, da qual a Flama devia fazer parte, via também em Ceausescu, apesar de ter um caráter mais ditador que Tito, um expoente de afrontamento para com o regime soviético.

O texto finda com a referência a momentos de tentativa da Romênia de se desligar economicamente da URSS, a fim de estabelecer uma liga com a Iugoslávia e com a Tchecoslováquia. A surpresa para Ceausescu ficou por conta de um inesperado apoio da China: “(...) que ofereceu auxílio militar e até talvez ajuda econômica à Romênia”. O "talvez", como marca lingüística, indica uma possibilidade. O uso pode ter se dado para demonstrar que isso poderia não passar ou de uma hipótese levantada pela Flama ou de serem apenas rumores que chegaram até a revista.

Ao longo do texto, temos alguns usos relevantes do sentido figurado que, juntos, contribuem para desqualificar não só as ações recentes da U.R.S.S., mas também a de um regime, que parece falido e arbitrário. Apesar disso, houve o oferecimento de apoio à Romênia, por parte da China. Como em muitos outros momentos, a revista, com determinados usos lingüísticos, aos poucos, fez, "em silêncio", ou seja, não se colocou contrária ao regime soviético, mas proporcionou dados para que o leitor assim chegasse a essa idéia, para que construísse um ethos do regime soviético. O texto da Flama reforçou a noção de um forte união entre os países socialistas, independentemente de estarem em diferentes continentes. 
A postura da revista de não atacar claramente o Kremlin propicia uma postura de certa 'neutralidade' calculada, uma vez que isso auxiliaria na edificação de um ethos de imparcial, almejada por muito órgãos de imprensa. 


\subsection{REVISTA O CRUZEIRO}

\subsubsection{O Cruzeiro número 14, ano XL, de 06 de abril de 1968.}

A capa não segue o habitual, ou seja, não traz uma moça bonita, normalmente uma atriz, cantora ou personalidade marcante da vida social de então. De autoria de um importante colaborador da revista, Carlos Estevão, podemos apreciar em um fundo branco, desenhos de variados bichos e em primeiro plano um homem, em cima de um poste, engolindo papéis e, ao que tudo indica, fugindo de um policial, que o ameaça, do chão, com um revólver. No canto inferior direito, com letras vermelhas, lê-se "Onde o jogo do bicho corre sôlto".

O sumário do presente número encontra-se na página 23, após três reportagens: "VIETNAME: a face sangrenta da guerra", "Onde o bicho corre solto" e "A roda viva do mundo". Ainda nessa página, temos uma pequena foto da candidata à miss Guanabara, em que se anuncia para a página 30 a reportagem com a bela moça. Essa revista está dividida em quatro partes: "Reportagens", "Seções", "Humorismo" e "Política". Quanto à seção intitulada "Reportagens", temos vinte e um itens. Nessa parte da revista, encontramos textos variados, que se referem à cultura, de uma forma geral, com reportagens sobre festival de música, entrevistas com diretores de cinema, uma retrospectiva da música popular brasileira, entre vários outros artigos, com assuntos diversificados, como um, relativo à moda e um item 'Na roda viva do mundo', que traz informações atualizadas sobre questões sociais e políticas de outros países.

Na parte "Seções", há mais nove itens, normalmente textos de colaboradores com base em variados assuntos, desde palavras cruzadas, horóscopo a assuntos que envolviam economia, assuntos relativos a notícias do Brasil, em distintos estados, além de um texto de Raquel de Queiroz, uma metalinguagem, já que explorava o teor de seu artigo versava sobre o gênero ficção científica, a partir de uma outra publicação dos Diários Associados, a revista galáxia. O segmento "Humorismo" conta com quatro itens, que vão de charges, crônicas, além da página destinada ao Amigo da Onça e, para finalizar, "Política" com apenas um item "O silêncio dourado do Presidente", que versa sobre uma análise do 
primeiro ano de governo de Costa e Silva, além de explorar questões como a vinculação do voto, a sucessão presidencial.

Procederemos, inicialmente, como o feito com as revistas portuguesas, a uma descrição da matéria, cujo tema foi escolhido para capa. Causa até um certo estranhamento esse número da revista, pela oposição da capa, em que há um desenho que retrata, de forma bem humorada, a contravenção do jogo do bicho, legitimada em muitas cidades de todos os estados do Brasil e a matéria principal, sobre a guerra do Vietnã.

Em outros exemplares de $\mathrm{O}$ Cruzeiro, o mais comum para o texto relativo à capa eram artigos mais longos e aprofundados. Entretanto, na edição em pauta, a reportagem contou com quatro páginas, sendo que as duas primeiras apresentavam-se sobre um fundo amarelo forte, os mencionados bichos, presentes no popular jogo, desenhados em preto e com um título em caixa alta e letras vermelhas: "Onde o bicho corre solto". No corpo da reportagem, propriamente dita, o título da capa não é reproduzido na íntegra. A palavra jogo é omitida e, assim, encontramos, pelo contexto, uma ambigüidade, pois se o jogo é proibido, correr solto significa uma contravenção e denotativamente o bicho correr solto implica numa ação própria de muitos animais, reflexos de atos pertinentes. Há, portanto, no trecho, um pretendido jogo com as mencionadas palavras.

$\mathrm{O}$ artigo sobre o jogo do bicho foi explorado de forma superficial, no entanto, essa prática de jogo mostrou-se instituída em alguns lugares do Brasil, como que inserida num código coletivo. Por meio da conjunção do plano de expressão e do plano de conteúdo, o provável é que o leitor não fizesse uma avaliação negativa do que parecia uma prática inofensiva, organizada.

É possível mesmo fazer uma leitura na defesa do jogo. Obviamente que defender o que por lei é tido por contravenção poderia macular a imagem da revista. Dessa maneira, o discurso é planejado na justa medida, para que não haja um claro envolvimento ideológico.

A terceira página traz dois desenhos dos respectivos animais: pavão e veado, além de um pequeno texto. A matéria é finalizada na quarta página, em que há apenas fotos. São seis, todas de registro, uma vez que contribuem para a ancoragem do assunto tratado.

É uma reportagem cujos créditos das fotos são atribuídos a Pedro Luiz e as ilustrações a Carlos Estevão, assim, como colaboradores da revista, revestem-se do chamado de sujeitos 2. O texto, embora não siga exemplarmente os moldes de um editorial, também não é 
assinado. Antes do início propriamente do texto, com letras maiores e em azul, obtemos a informação de que o jogo do bicho era livre em Recife e tanto quem trabalhava nessas casas de aposta como quem "fazia a fézinha" não tinha do que reclamar, já que tudo corria conforme as práticas legais trabalhistas e de apostadores.

A reportagem apresenta um texto com apenas sete curtos parágrafos. Em linhas gerais, o que se vê é a oposição, mesmo que implícita, entre: legalidade e ilegalidade. No primeiro parágrafo, temos além do horário de funcionamento, as regras para jogar, bem como se obtinha o resultado da aposta. No segundo parágrafo, é possível verificar a existência de uma voz, que não parece solitária, mas difícil de identificá-la, pois é anônima.

O pretendido anonimato se justifica por haver uma denúncia ou acusação: "À boca pequena corre que o governo do Estado é conivente com o jôgo”. Sutilmente, o uso do pronome indefinido "ninguém", seguido do verbo na terceira pessoa do plural "dizem" são marcas claras de uma intencional indeterminação do sujeito, uma forma de não se comprometer com a situação mencionada. Há ainda no trecho uma referência comprometedora, já que se afirma haver uma "taxa de fiscalização". Não é esclarecido quem cobraria tal taxa, mas pelo contexto não fica difícil saber se tratar do próprio governo do Estado. No quarto parágrafo, afirma-se a respeito da impecável organização da "empresa", algumas com balanços diários de seus lucros. Com a intenção de elevar à categoria de um estabelecimento comercial como outro qualquer, existe a menção ao tipo de pessoa que nessas casas trabalha: “(...) gente especializada no assunto”.

A informação relevante do quinto parágrafo fica por conta do funcionamento do jogo, sua forma organizada de se firmar, um jogo que fazia parte da vida das pessoas, ao menos rotineiramente em Recife, desde a época de Getúlio Vargas. O penúltimo parágrafo apresenta o que seria uma justificativa para sua manutenção: "Segundo os entendidos, o jogo do bicho está mais do que integrado no espírito nacional”. Novamente temos uma voz que se esconde, entretanto pelo trecho, mostrou-se a favor da manutenção do jogo, como estava, em Recife.

O parágrafo final revela que houve mudança no jogo: "No Recife (...) uma nova era do jogo do bicho. Acabou-se a emoção de antigamente. O bicho agora é indústria séria”. Como no trecho final, vemos uma crítica nessa mudança ocorrida no famoso jogo, habitualmente também chamado de "Para todos". 
Encontramos, mesmo num texto curto, incontestes vozes, a da revista, de algum modo ancorada por imagens que servem para dar maior credibilidade ao assunto. Algumas são fotografias das fachadas das lojas. Enfim, um recurso importante, já que auxilia na construção da credibilidade da matéria. Por outro lado, há a voz, provavelmente não individual, que aponta o jogo como instituído, ao menos em Recife. Como o esperado pelo contexto, não há uma voz que seja a representação oficial, de alguém do governo para confirmar ou desmentir o fato apresentado. O provável disso seja a inquestionável verdade, amparada por fotos e relatos de apostadores e/ou conhecedores dessa realidade, que devia e deve continuar a se estender por todo o território nacional.

Se há certo descompasso entre a capa, cujo assunto não é dos mais relevantes e a matéria principal do número, temos uma pressuposição para isso. Uma hipótese para uma capa fora do habitualmente visto em O Cruzeiro, inclusive em números de outros anos, tenha se dado como forma de se auto-preservar e não apresentar uma foto da Guerra do Vietnã, cujo assunto, nesse número, era o tema central.

Embora o foco do número esteja logo estampado com suas tristes cores na primeira página de $\mathrm{O}$ Cruzeiro, esse número da revista nos fez refletir mais quanto à escolha do texto a ser cuidadosamente analisado. O motivo disso se deu por causa de um dos itens da seção "Reportagem", o "Na Roda Viva do Mundo", pois apesar de haver vários temas que poderiam ser relevantes, tendo em vista o caráter político, apresentavam um formato mais de nota do que do gênero reportagem, dada à ênfase em noticiar um fato e não em explorálo, o que notamos até pelos restritos textos. Por outro lado, o presente número contou uma seção intitulada "Política", como já dito, com texto sobre o presidente Costa e Silva. O texto explorava as discussões na base militar para as próximas eleições para governador e para presidente. Compreendemos, contudo, que embora o texto trouxesse outros dados que poderiam nos levar a um levantamento mais ou menos ideológico, uma visão da revista mais ou menos em consonância com o governo militar, optamos pelo texto de maior relevo, tanto pela temática, como pelo forte apelo das imagens captadas do inferno vivido no Vietnã.

A seguir reproduzimos o apresentado pela revista, no item "Reportagem - Vietname: a face sangrenta da guerra, bem como a análise do texto, tanto em seu plano de conteúdo como em seu plano de expressão. 


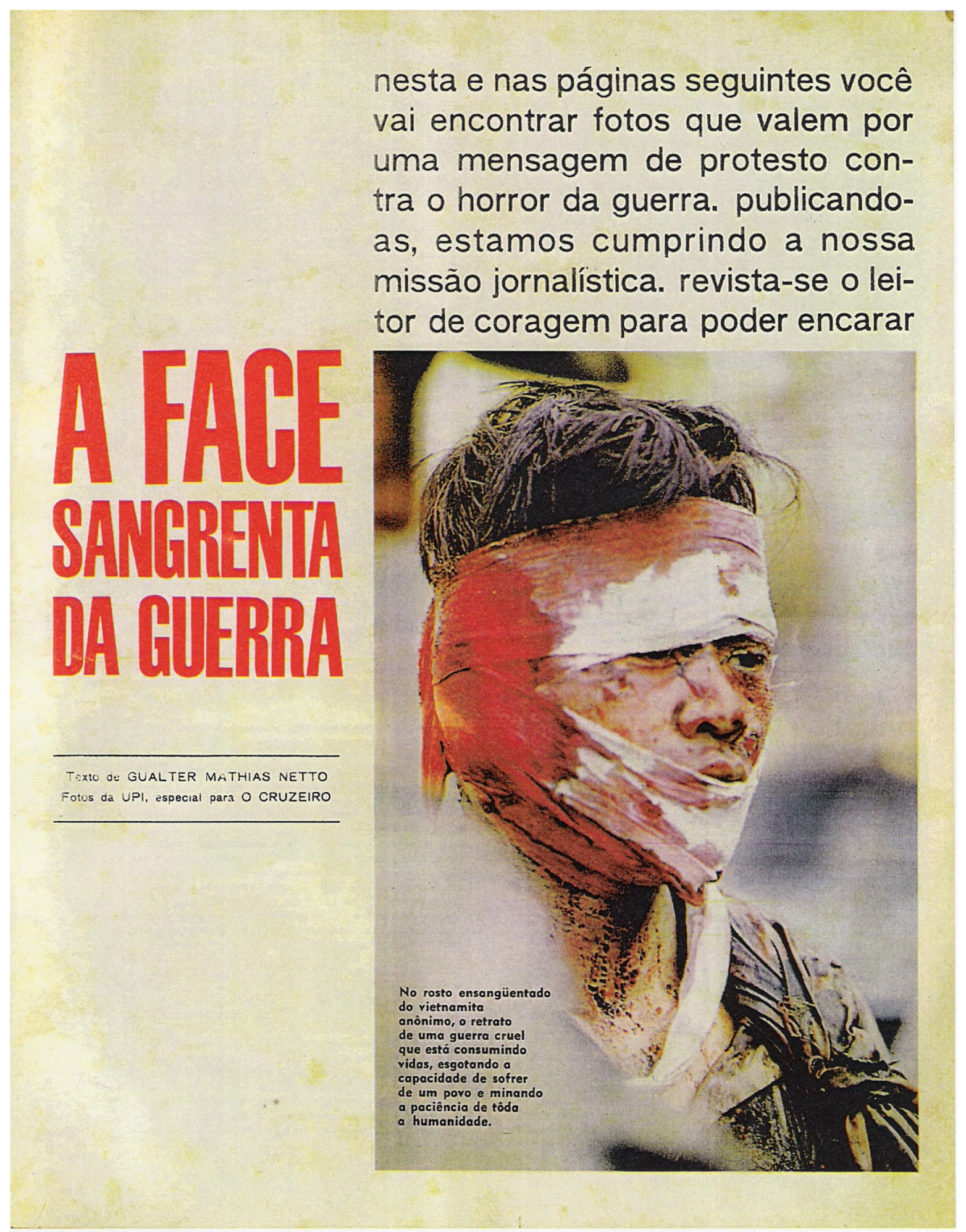




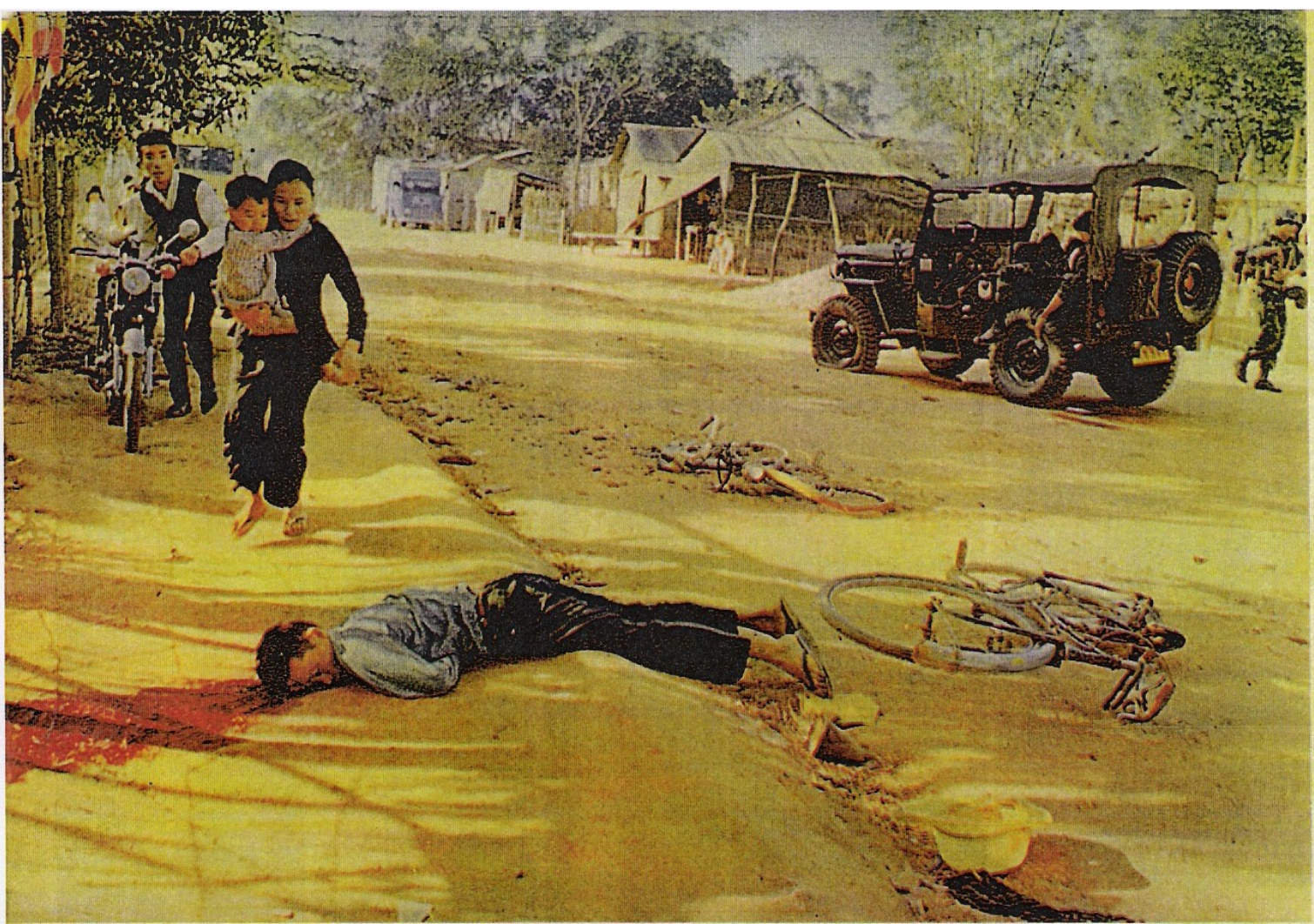

Familias em fuga se deparam a cada passo com os corpos em poças de sangue. O terror jó chegou às cidades. Fugir - fugir para onde?

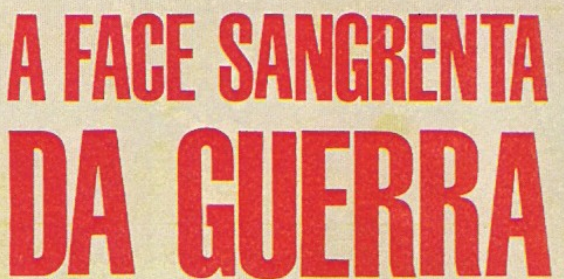

"1e

nome do Senhor, gritantas pungente partlu dos bispos quando, em 1966, o arceoll, núnclo apostólico no Canadá e envado especial de Paulo VI, entendeu-se com a cúpula Igreja Católica vietnamita para que se unissem esforças com as budistas com vistas a obter o fim da guerra. No Natal do mesmo aho, o cardeal Francis Spellman, entāo arcebispo de Nova Iorque, num sermão às tropas americanas no Vletname, clamou: "Tôda soluçāo que nāo fồ a nossa vitória é inaceitável."
Ambas as manifestaçōes refletem, em tons diferentes, o desejo universal de acabar com uma guerra que vem consumindo, ao longo dos anos, milhares de vidas submetendo $\circ$ povo do vietname a sofrimentos insuportáveis e exaurindo as reservas morais de tôda a populacaio mundial Entretanto, um a tos militares e diplomáticos do Ocidente: Como acabar com a guerra?

o esfôrço militar norte-americano no conflito do Vietname começou em forma de assistência em armamentos e conselheiros estratégicos. Aumentou consideràvelmente nos três últimos anos, atingindo, em 1968, a cifra de 507 mil homens, que será elevada para 525 mil até o próximo outono (primavera no Brasil) ou para muito mais, caso seja atendido o recente pedido do general william westmoreland de remessa de mais $206 \mathrm{mil}$ imediatamente. Em 1965, visando a impedir a infiltraçäo em massa de guerrilheiros e tropas regulares do Vietname do Norte ao suldo paralelo 17 , os Estados Unidos miclaram a cosalda abea ao pals de Ho Chi Minh, em bombardelos trequentes sobre Hajphong, Hanô e cut bos pontos estrategcos. O resultado náo fol o esperado. No principlo da escalada, as torças norte-vietnamitas no victname do Sul ocçavam em cerca de 5.000 soldados; hoje-êles são mais de 112.000 . E quando o general Westy fazia declaraçoes otimistas sôbre o panorama do conflito os comunistas empreendiam a maior ofensiva de tôda a guerra, atacando ao mesmo tempo numerosas cidades em tódas as quatro zonas táticas daquele país. 


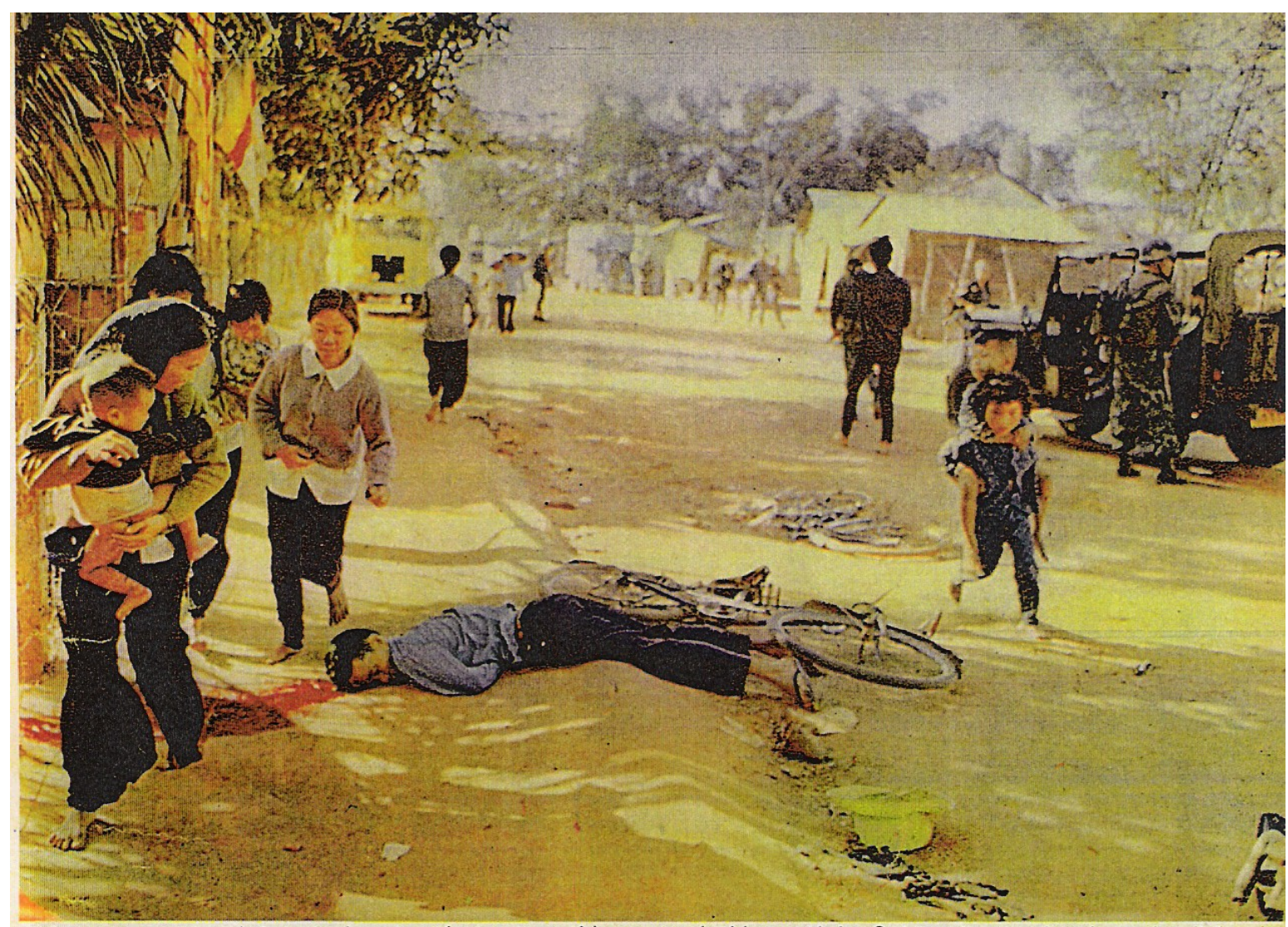

A cena se repete a cada instante. A morte está presente em tôdas as ruas de tôdas as cidades. O vietnamita aprende cedo sua dura lição.

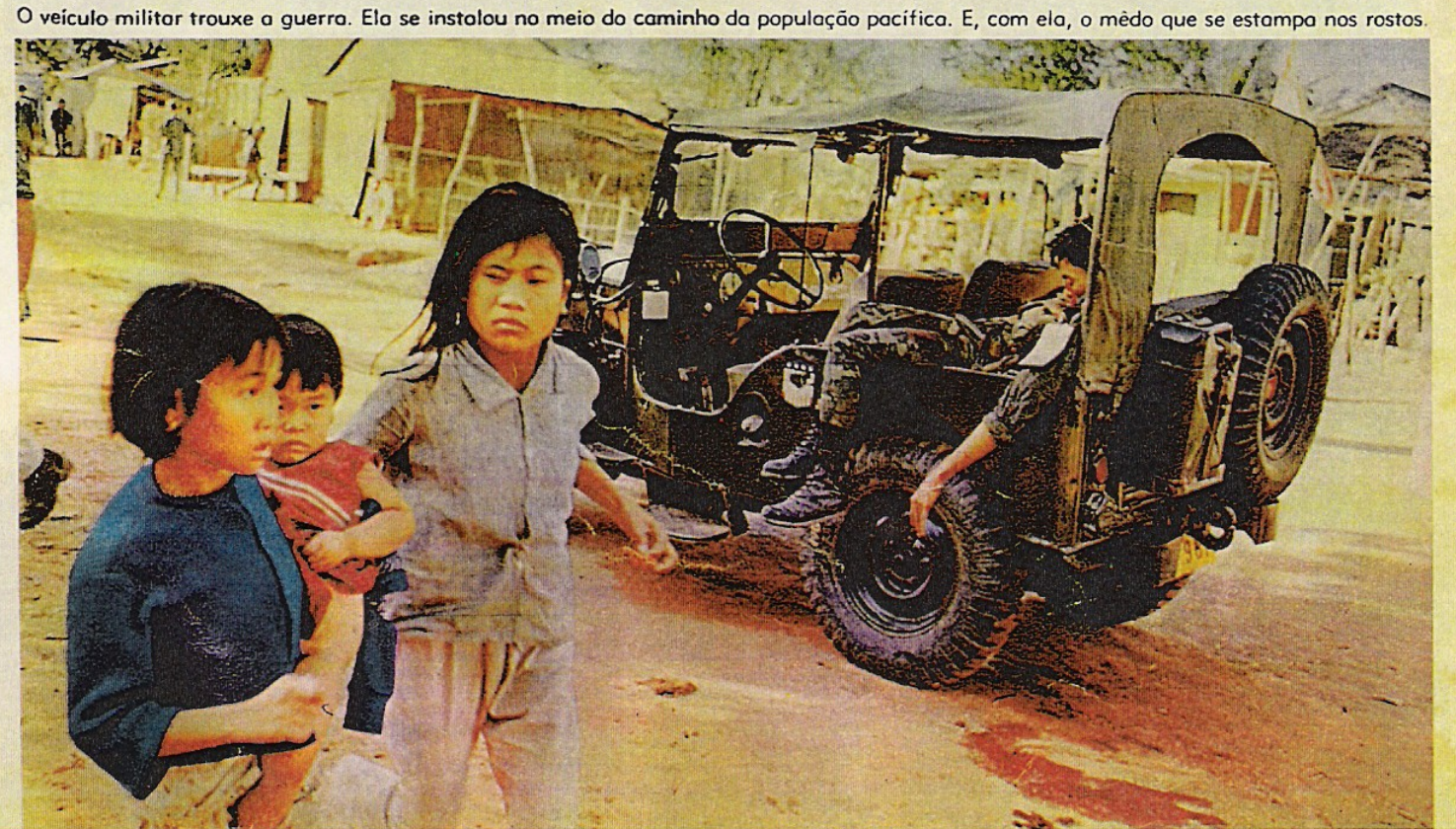




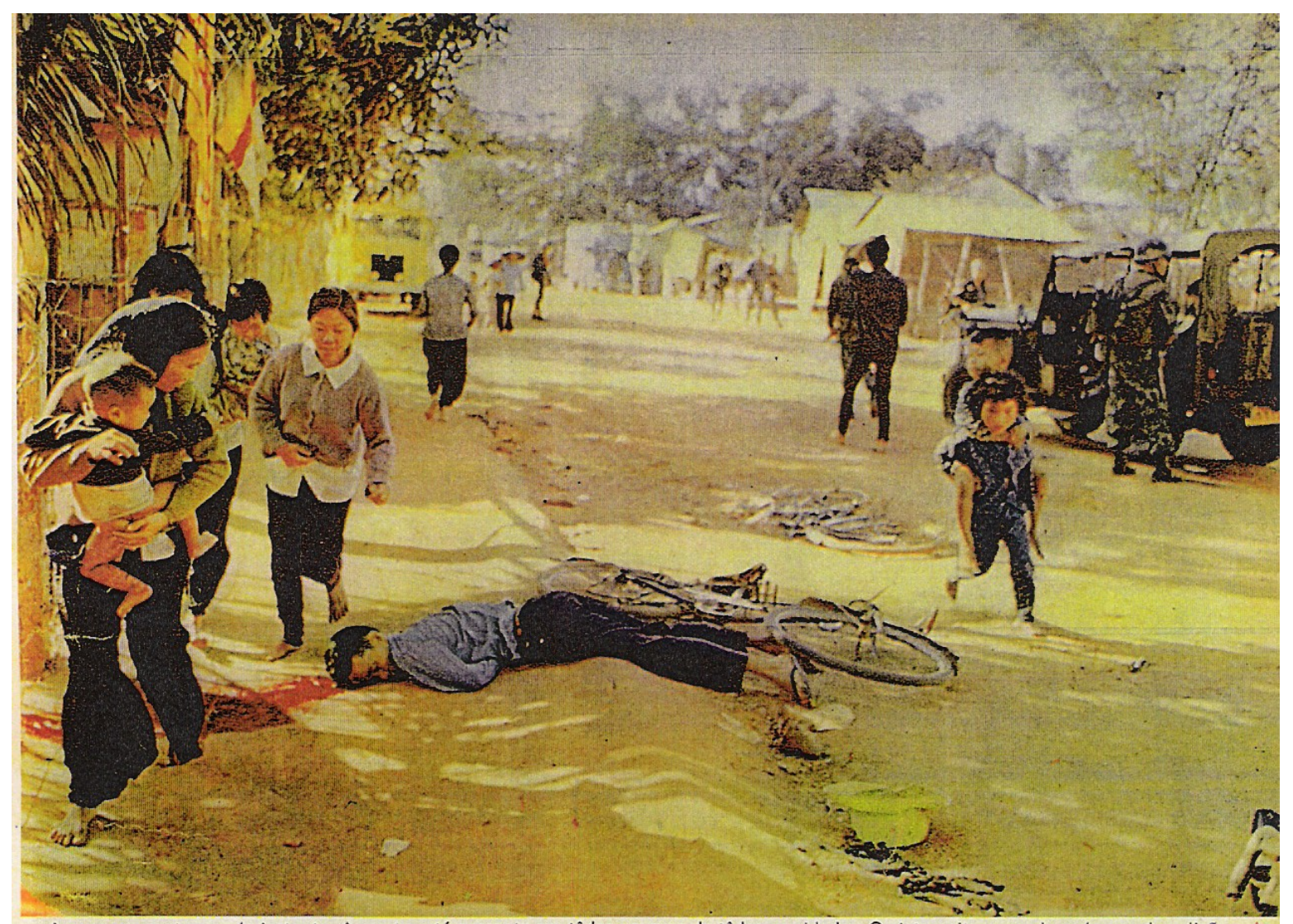

A cena se repete a cada instante. A morte está presente em tôdas as ruas de tôdas as cidades. O vietnamita aprende cedo sua dura lição.

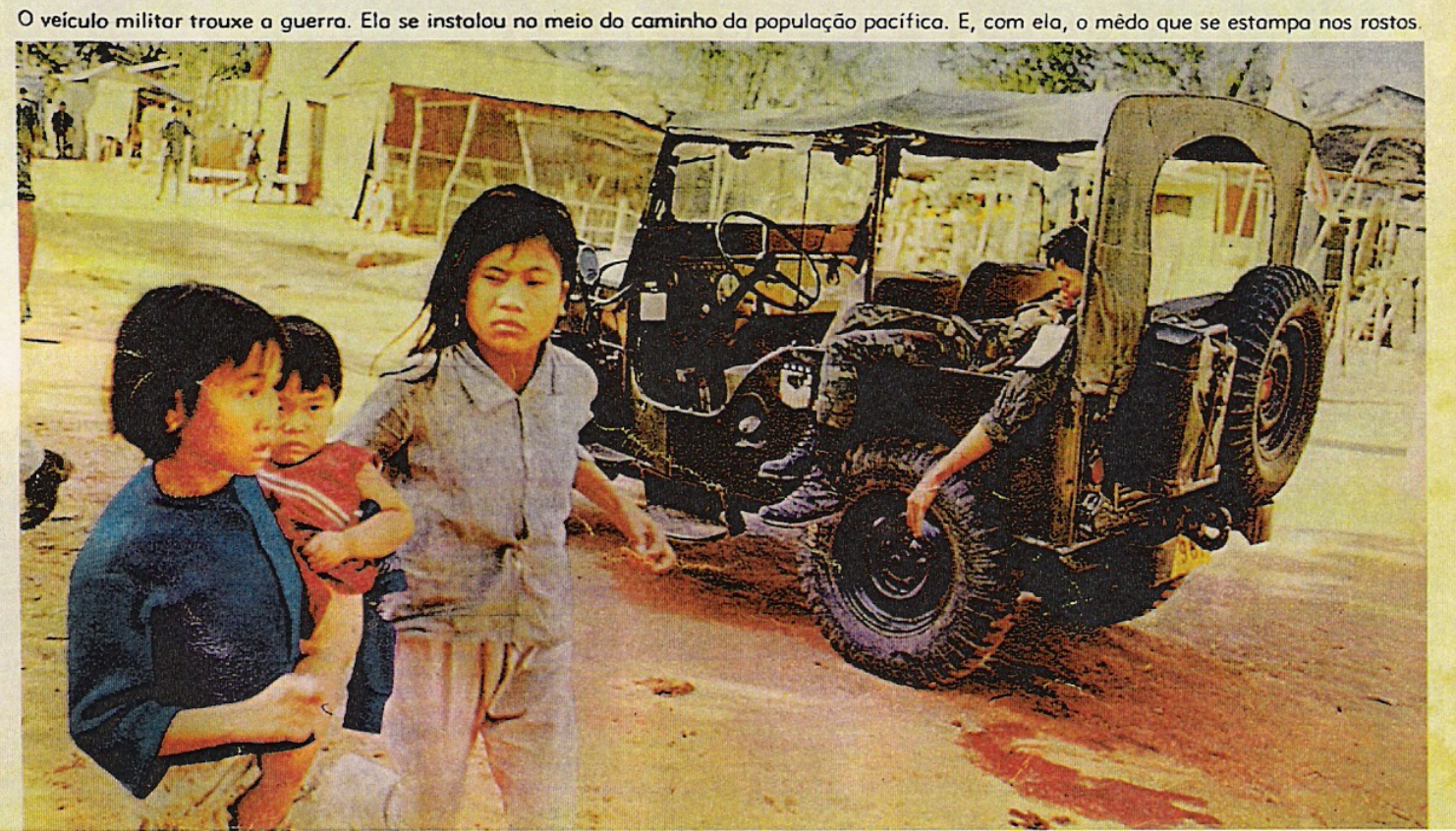



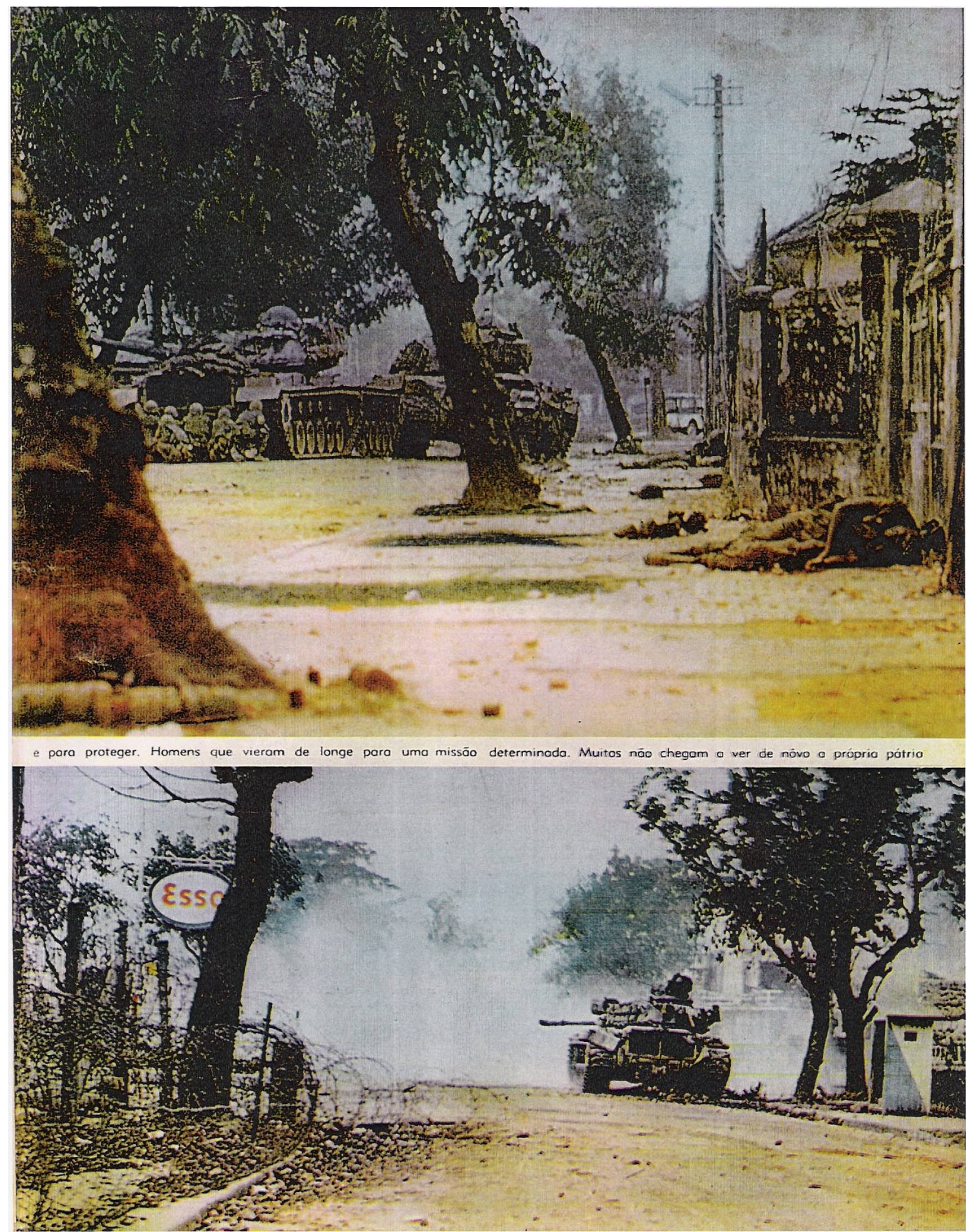


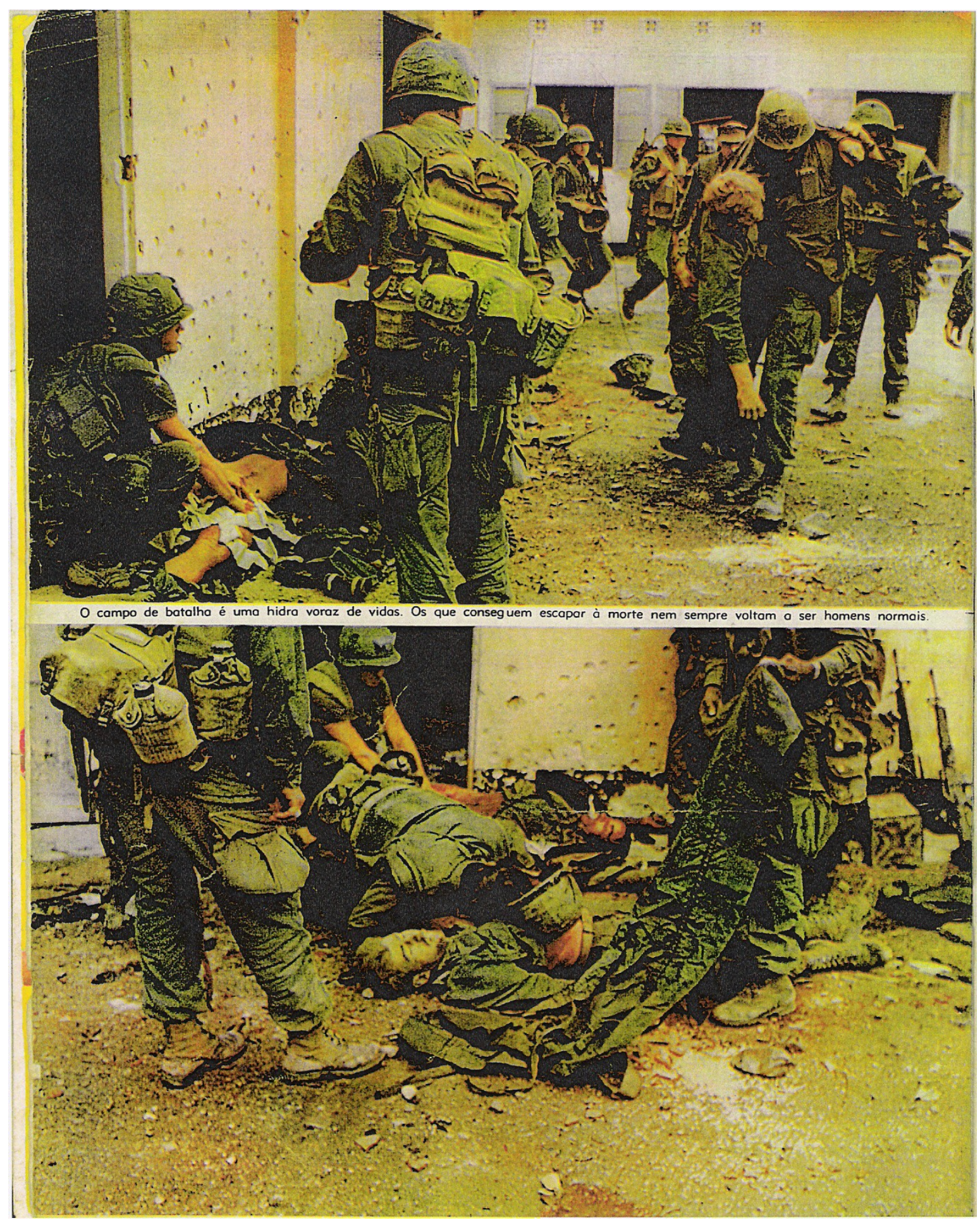




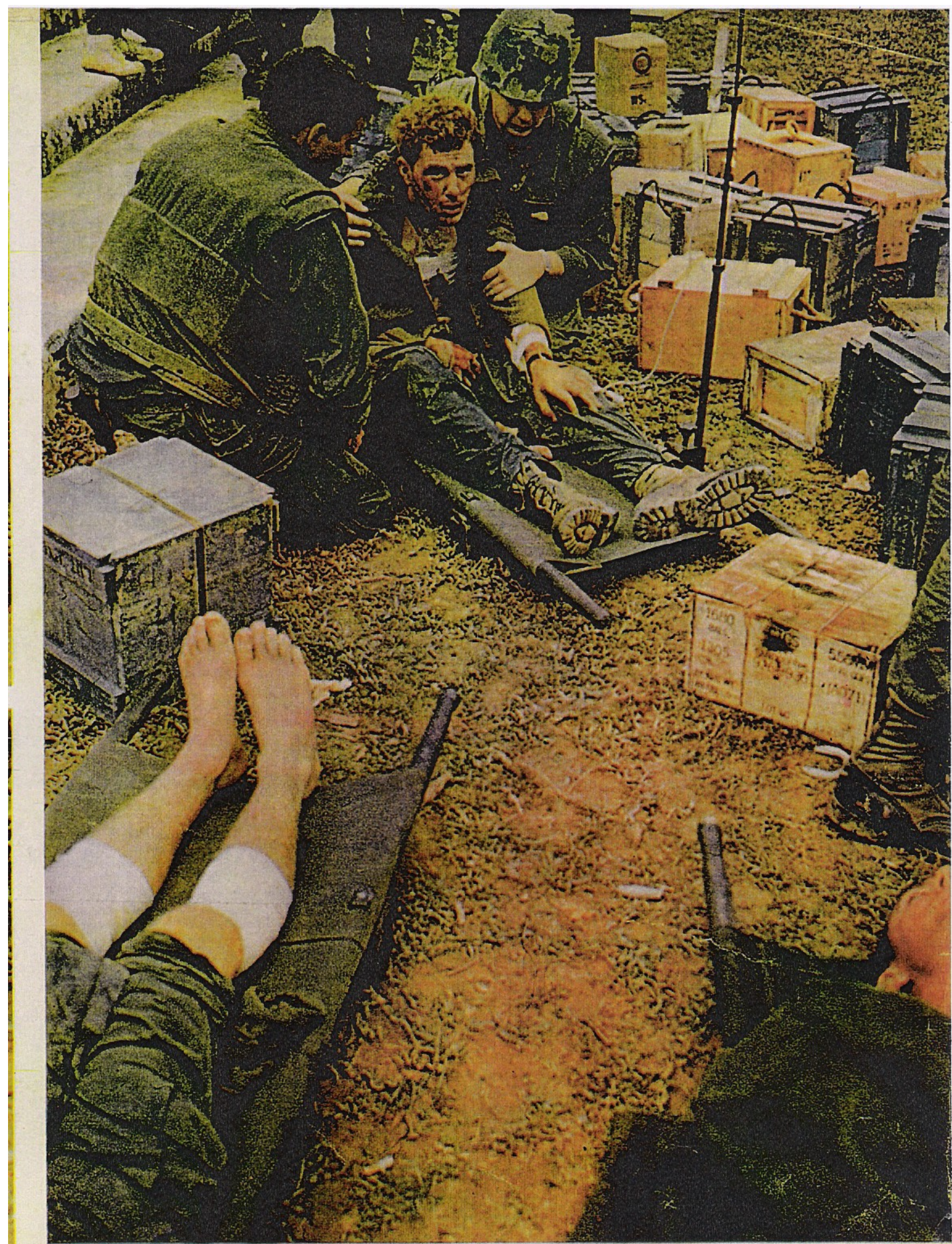

A FACE SANGRENITA

As cifras das baixas demonstram o extensão da carnificina da guerra. $O$ total das perdas, durante três anos de luta no Vietname, segundo números oficiais, jó está ultrapassando o de tôda a guerra da Coréia: $19.313 \mathrm{mor}$ tos, contro 33.629 , e 117.680 feridos, contro 103.284 , ou seja, 136.993 baixas no Vietname, em três anos, para 136.913 no conflito coreano. 


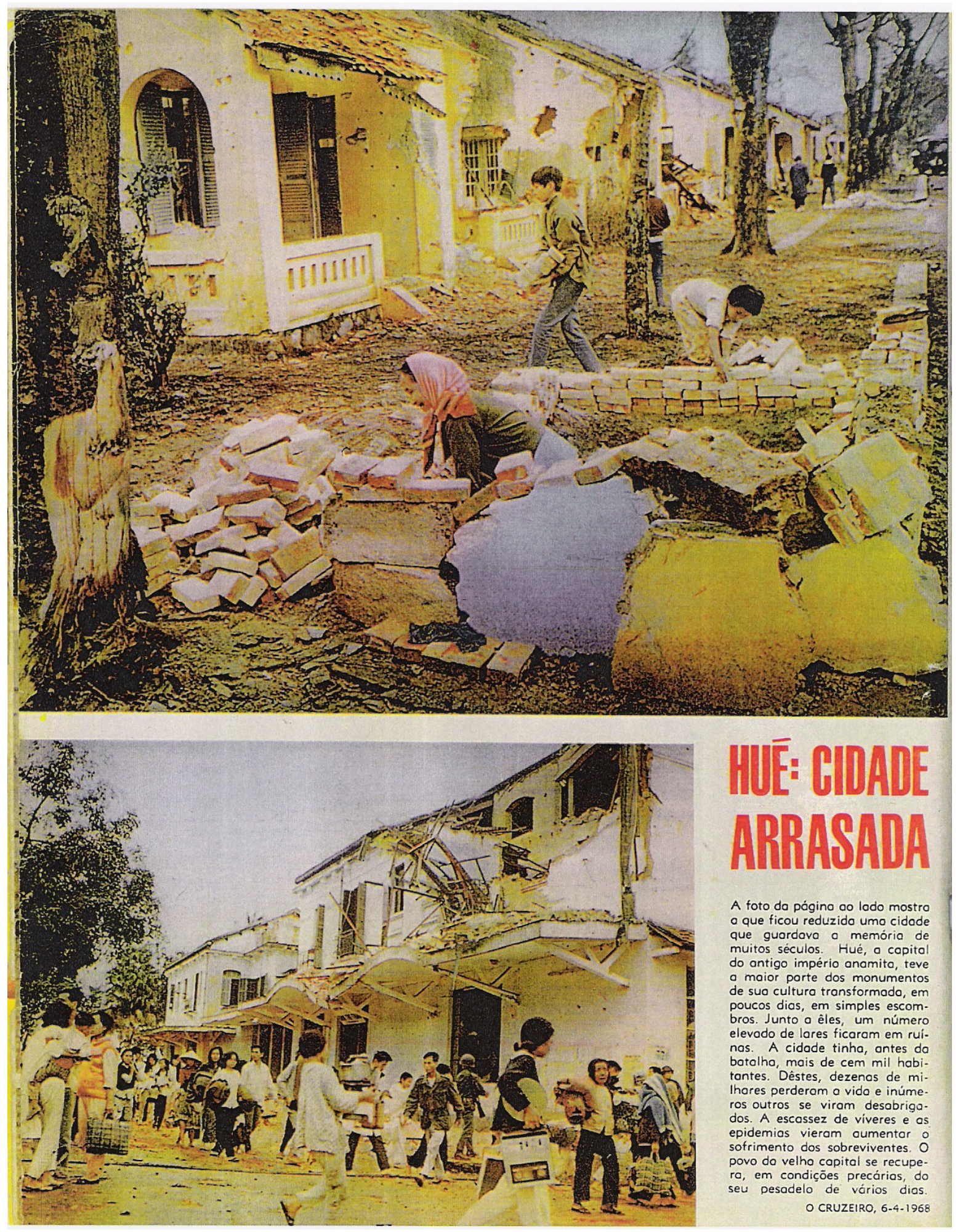




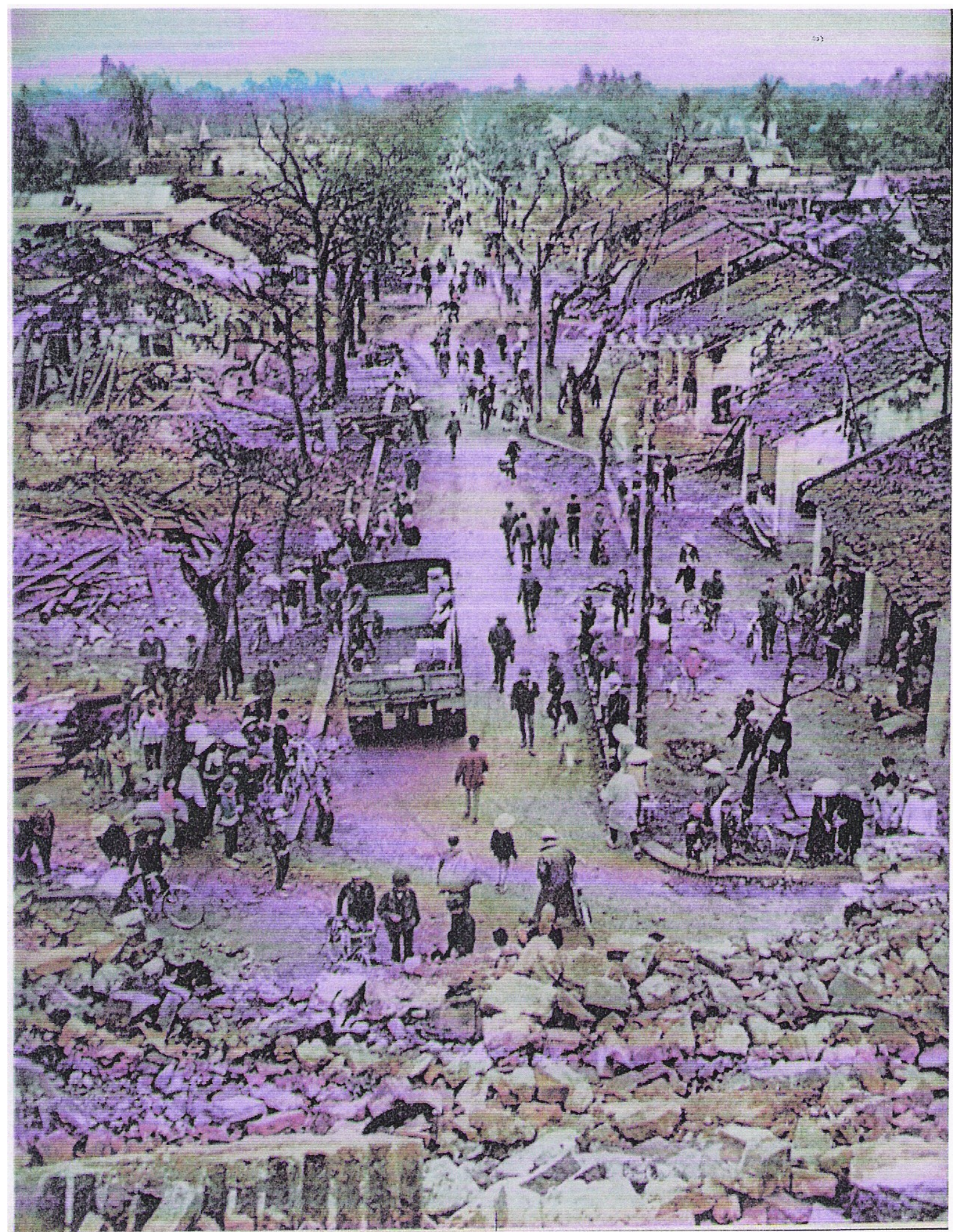




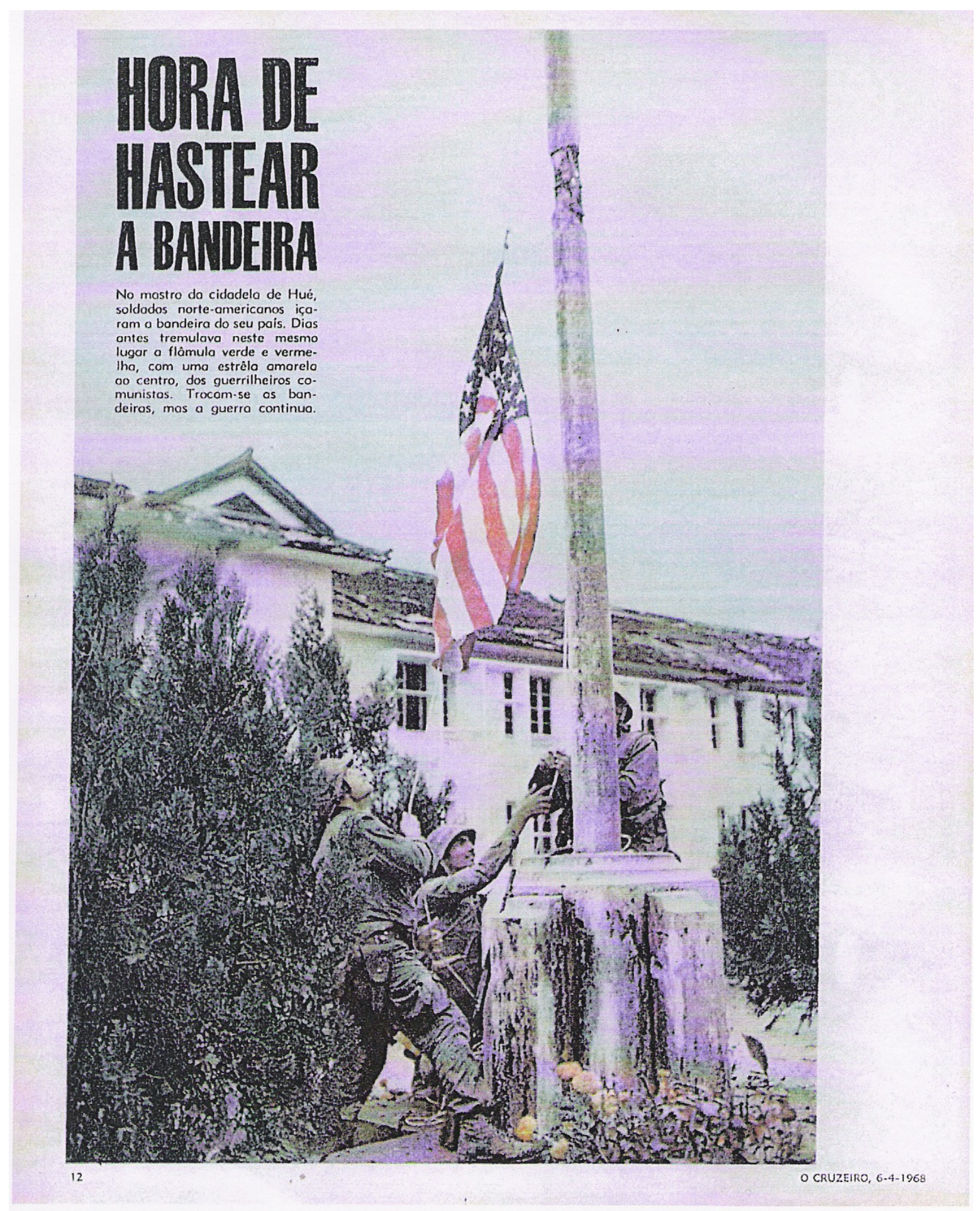


Sem a intenção de nos remetermos a teóricos específicos, já que não nos é fulcral, segundo nosso foco de análise, achamos pertinente refletirmos sobre a distinção entre o que se pode chamar de imprensa de referência e imprensa popular. Aquela é tida como não só mais séria, pretensamente mais imparcial, como também a escolhida pelas classes mais altas da sociedade, pelas pessoas mais bem formadas. Por outro lado, a imprensa popular preza pelo amplo apelo mais explícito, a fim de atingir o seu público, normalmente pessoas mais simples. A imprensa popular atinge seu objetivo, lançando mão dos chamados “factóides', aliados a um linguajar menos formal, às vezes até menos polido e conta ainda com o recurso de imagens bastante fortes, muitas vezes explícitas de um acontecimento, às vezes com uso de fotografia chamadas de fotos de flagrante. Não que essas não sejam exploradas pela imprensa de referência, no entanto, ao menos hoje, o mais comum é a não exploração, nessa mídia mais cuidadosa, de imagens muito violentas ou que exponham muitas pessoas envolvidas em um determinado fato, assim como uma preocupação com a estrutura textual.

Se isso é o comum hoje, imaginamos uma certa mudança, de postura da imprensa sensacionalista ao longo das décadas. O domínio exercido pela imagem é inconteste e na mídia imprensa auxilia, numa conjunção de estilos, num hibridismo da linguagem que seduz o leitor. Grillo (2004) afirma ser a primeira leitura, aquela mais veloz na qual o leitor se detém mais nos títulos e nas imagens. Na matéria em questão, é difícil não ficar perplexo diante de fotos com alto teor de violência, em que os mortos e feridos são flagrados com destaque, bem como o sangue derramado e "capturado" pelas lentes dos fotógrafos.

O Cruzeiro seguia os cânones da imprensa de referência na época e, mesmo assim, contou com esse forte recurso no plano de expressão da imagem, para corroborar o apresentado pelo plano de conteúdo. A partir do acima exposto, entendemos, então, como pertinente essa hipótese de ter havido uma bastante perceptível transformação na imprensa de referência.

Passemos, então, à reportagem: "A face sangrenta da guerra". Como o recurso tipológico é bastante importante, como o esperado, no contexto os tipos empregados são grandes e vermelhos, vermelhos da cor do sangue, explorado já no título. Se voltarmos ao afirmado em Hernandes (2006), no que se refere a esse recurso gráfico, que é uma simulação do som, leremos o título como um grito, um grito de alerta para o massacre cruel 
e constante a civis. A reportagem é assinada e as fotos trazem por crédito "Fotos da UPI, especial para O Cruzeiro". São dez páginas repletas de chocantes fotos coloridas, num total de catorze.

O título da reportagem é reforçado por uma grande foto, em que se vê o rosto ensangüentado, muito machucado de um vietnamita. Recurso bastante apelativo, pela violência explícita num olhar desolado do ferido. É uma foto de síntese, em conformidade com o visto em Hernandes (2006). O civil é a personificação da crueldade, é o resultado sintético das ações militares. Essa composição, antes mesmo de começar o texto, é uma estratégia para advertir o leitor do que viria a encontrar nas seguintes páginas, o retrato de um massacre. $\mathrm{O}$ aviso ao leitor se é explícito na foto, é explicitado, também, verbalmente em: "nesta e nas páginas seguintes você vai encontrar fotos que valem por uma mensagem de protesto contra o horror da guerra. Publicando-as, estamos cumprindo a nossa missão jornalística. Revista-se o leitor de coragem para poder encarar". Nesse trecho, somado aos créditos da foto, encontramos a voz do sujeito 2, do jornalista Gualter Mathias Netto.

Chamou-nos a atenção a tentativa de justificar o uso das imagens chocantes e sensacionalistas como um dever no protesto contra a guerra. Contudo, sabemos que imagens desse tipo, de impacto e de violência, despertam em grande parcela da população um sentimento de curiosidade e de repulsa, mas que possui um forte apelo comercial. Haja vista a existência de uma imprensa dita marrom, originada na Inglaterra e que, na década de 60, já começava a ocupar um espaço na imprensa brasileira. É possível estabelecer um paralelo entre os atuais programas de rádio e de tv, detentores de um discurso de condenação e de apologia à violência.

A guerra que parecia infinda era tanto refletida em todo o mundo, como com igual repercussão, refratada, contestada. Eram vozes, especialmente no cenário Ocidental, que se mostravam contrárias à guerra do Vietnã. No fragmento retirado dos créditos da primeira foto, percebemos o repúdio às ações militares: “(...) uma guerra cruel que está (...) minando a paciência de tôda a humanidade”.

O texto não é muito longo, nem precisaria sê-lo, as fotos com seus sintéticos créditos "falam" muito e comovem a todos. A segunda página da reportagem traz uma foto em que se vê um menino, talvez um adolescente morto, caído numa calçada, rodeado por sangue e famílias tentando fugir, mas o provável é que nem soubessem para onde. Na terceira página 
do artigo, composta por mais duas fotos, a primeira fotografia parece a seqüência da vista na página anterior. O rapaz morto continua a ser observado por outras pessoas que lutavam para fugir daquele inferno. Não podemos afirmar o que mais choca, mas chama atenção crianças novas assistindo àquele horror, expostas, tão cedo, a um grau inimaginável de violência. A segunda foto da página traz três meninas, com aspecto bastante assustado, andando por uma das ruas e na proximidade se vê outro morto, dessa vez um militar vietnamita, dentro de um Jipe.

A quarta página traz uma foto de homens em combate. Na quinta página, apenas com imagens, vemos mais duas fotos. Na primeira, vêem-se soldados fazendo de trincheira os tanques de guerra e, pela calçada, mais mortos. A segunda foto da página mostra um tanque de guerra, em uma rua repleta de fumaça, em conseqüência dos fortes e incessantes ataques, tendo como parte do cenário uma placa com o logotipo de uma grande empresa do ramo petrolífero, um ícone do capitalismo.

Assim como a foto da página anterior, ambas de registro são mais brandas, já que não se vêem mortos. A sexta página traz fotos em que se vê um possível abrigo ou alojamento de soldados americanos, uns feridos, outros mortos, tendo ao fundo uma parede cravejada por balas inimigas. A sétima página apresenta a foto de um soldado muito machucado, sendo atendido por outros dois, além de mais militares estendidos no chão, machucados ou já mortos.

Novamente o título da reportagem, entre aspas e com letras grandes e vermelhas, aparece: "A face sangrenta da guerra". O efeito é de ratificação da barbárie. Os créditos não amenizam as imagens, fala-se em "Carnificina da Guerra" e seguem com os números absurdos de baixa no conflito, que já atravessava anos.

A página seguinte da matéria traz mais duas fotos, ambas de registro, em que se vê a população da cidade Hué tentando reerguer o que sobrou. Outra vez com letras grandes e vermelhas é possível ler o último subtítulo da reportagem: "Hué: cidade arrasada". A penúltima página é, ainda, uma continuação da amostra a que se reduziu a cidade, em que é possível ver a destruição e muitas pessoas no que sobrou do lugar. A última página da reportagem, quase como uma visão do que era corrente na época acreditar, que o fim do conflito estava próximo, há a foto de síntese para o momento esperado pelos americanos, ou seja, quando se sagrariam vitoriosos. Numa referência a esse histórico momento, vemos 
soldados norte-americanos hasteando a bandeira dos Estados Unidos. Para essa conclusão da matéria, lemos em caixa alta: "Hora de hastear bandeira" e, na seqüência, os comentários sobre o que seria a ordem do dia, ou seja, as troca da bandeira dos comunistas pela bandeira dos americanos. A imagem traz uma dupla mensagem, na medida em que o "hastear a bandeira norte-americana" simbolizava, se não de fato, uma maneira de se mostrar mais próximo da vitória, era um recurso ideológico para tentar minar as forças dos vietcongs.

Se falarmos num recurso ideológico, no caso a troca das bandeiras, não é uma ação incomum, num contexto de guerra, entretanto, é preciso ressaltar a questão ideológica da revista, ao não só escolher essa imagem para a composição do plano de expressão, como aliado ao sincretismo da linguagem, por meio do plano do conteúdo, com créditos, em que se lê: "Trocam-se as bandeiras, mas a guerra continua". Há uma carga ideológica forte, sintetizada pelo soldado americano, num momento de êxito.

No que diz respeito ao aspecto verbal, o texto organiza-se apresentando a esperada dualidade de posicionamento. Por um lado, na postura arbitrária dos Estados Unidos de se manterem em uma guerra, mesmo com a forte oposição de uma significativa parcela dos americanos e, por outro lado, uma voz coletiva intercontinental que desaprovava os terrores dessa guerra. Há que se levar em conta que apesar de, após a Primeira Grande Guerra, os Estados Unidos terem saído como uma grande potência capaz de decidir muito dos rumos da História de então, de serem grandes exportadores, sobretudo de capitais e um importante consumidor, inúmeras nações, para as quais uma relação amigável seria bom, comercialmente falando, colocaram-se contra atrocidade acometida pelo país, sobretudo, contra civis inocentes.

Esse posicionamento crítico aos Estados Unidos também ficou claro por parte do Brasil como um todo e especialmente expresso pelo jornalista, a serviço de O Cruzeiro. Era a voz da empresa "Diários Associados" que também se manifestou, mesmo que num segundo plano, uma vez que o texto não era do gênero editorial e sim do gênero reportagem assinada.

No artigo, não há uma concreta manifestação da fala de um civil comum vietnamita. A situação daquele povo era de tamanho desprestígio, que mesmo órgãos de imprensa, apesar de majoritariamente contrários à guerra, não abriram espaço ou não tiveram como abrir 
espaço para ouvir a voz sofrida de representantes daquele povo. No texto, essa voz emudecida gera um espaço para outras vozes, por exemplo a imprensa, seus colaboradores e também os religiosos.

Se a voz do jornalista se faz clara em algumas passagens, o fato de a revista ter dado tanta ênfase ao assunto também faz com que reconheçamos a sua voz. Logo no primeiro período do texto, encontramos uma outra voz, reproduzida em discurso direto: "Em nome do Senhor, gritamos basta”. Tratava-se de um apelo dos bispos católicos sul vietnamitas, ou seja sujeitos 3, personagens da triste história, mas também pressupomos a voz do sujeito 1, na medida em que como veículo de informação, cumpre com seu papel, ao abrir espaço para a divulgação de como as pessoas, em seu dia-a-dia, conviviam com a guerra.

Especificamente no que diz respeito à súplica reproduzida, o provável é que essa voz tenha sido proferida tanto sob a perspectiva de um civil que vivia o inferno na terra, como na perspectiva de um homem religioso, que clama pelo Senhor. A utilização do verbo no presente, próprio do plano discursivo da enunciação, mais uma vez se apresenta como recurso para mostrar a proximidade do momento em que o apelo foi exposto.

São várias vozes oficiais da Igreja Católica: o arcebispo Sérgio Pignedoli: “núncio apostólico no Canadá e enviado de Paulo VI” - voz oficial da Santa Sé, na figura do Papa, engrossada pelo coro de outros bispos que ainda buscavam apoio no apelo de outros religiosos, os budistas. Como o lugar de onde se profere um discurso é extremamente relevante, no contexto, em especial, a Igreja assumia um importante papel na defesa da paz. $\mathrm{O}$ grito produzido por um religioso provoca um impacto muito maior junto à opinião pública.

O pedido feito pelo bispo não era recente: “O apêlo (...) dos bispos partiu (...) quando, em 1966, o arcebispo (...) Pignedoli (...) entendeu-se com a cúpula da Igreja Católica (...) para que se unissem (...) com os budistas com vistas a obter o fim da guerra”. O recurso da Igreja Católica foi unir-se a outros religiosos, numa tentativa ecumênica de fazer soar uma voz coletiva religiosa, comprometida com os fiéis. O dêitico temporal "em 1966" reforça a crença em ações contínuas da Igreja, objetivando a paz.

Por outro lado, uma outra voz religiosa se fazia ser ouvida, de forma questionável, tomando-se por base o desejo de paz. A voz em questão era do arcebispo de Nova York, que também em 1966, num sermão, afirmou: "Toda solução que não for a nossa vitória é 
inaceitável”. Essa fala não só tinha o poder de incitar os soldados a continuar na guerra e lutar veementemente pela vitória, como legitimava a ação militar, a partir de uma voz que poderia ser tida como porta-voz, o porta-voz de Deus.

O segundo parágrafo contemporiza as duas manifestações da Igreja, uma vez que ambas, movidas por diferentes visões da guerra, almejavam o mesmo, o fim do conflito. Todavia, a crítica ao estado a que estavam reduzidos os vietnamitas é visto ao longo de todo o texto. O jornalista utilizou-se de variados recursos linguísticos para não só enfatizar, como comover e conseguir adesão, na medida em que apresentava a "verdade”. Em:“(...) exaurindo as reservas morais (...)”, o repórter, ao utilizar o gerúndio, reforçou as ações contínuas que estavam tendo como reflexo o que seria a última característica que um indivíduo deveria perder, o moral. Um povo sem moral não tinha mais a dignidade.

O terceiro parágrafo faz referência ao fato de como os Estados Unidos chegaram ao Vietnã e com que objetivo. Nada mais apropriado do que o uso de verbos no pretérito perfeito, no trecho em que o plano do discurso é o da história. "O esfôrço militar norteamericano (...) começou em forma de assistência em armamentos e conselhos estratégicos”. Depois dessa retomada da entrada dos americanos, encontramos números que sinalizavam para um agravamento da situação: “Aumentou consideravelmente (...)”, em referência ao contingente enviado pelos EUA ao local do confronto. No trecho, a ênfase se dá pelo uso do advérbio de modo "consideravelmente".

Em alguns trechos, com o mesmo efeito de sentido da seqüência seguinte, observamos o uso da voz passiva. “(...) 507 mil homens, que será elevado para 525 mil até o próximo outono (...)”. A passiva é clara mostra dos soldados limitados a cumprirem o que o governo americano determinava. Um governo ativo, em constante ação, próprio de um país em guerra.

No trecho: “(...) os Estados Unidos iniciaram a escalada aérea ao país de Ho Chi Minh", temos uma ação coletiva de um país contrário ao que, pela estrutura do texto, pode ser lido como "um país de uma pessoa", como se Ho Chi Minh fosse proprietário do Vietnã. O recurso lingüístico pode ser compreendido como a explicitação do motivo do confronto, as idéias do importante líder comunista, um comunista de carreira e de escola, que viveu na então União Soviética, mostrava-se não só ferrenho seguidor do comunismo, 
como um obstáculo para os americanos, já que ampliava a área de atuação dos preceitos advindos do Kremlin.

A reportagem segue com a parte verbal na quarta página, em que o título da matéria é repetido: "A face sangrenta da guerra". O primeiro parágrafo reforça a explícita polifonia verificada em: "A campanha do Tet levantou muitas vozes em todo o mundo, pedindo o fim da guerra (...) clamores esparsos que se ouviam em diversos pontos do globo”. Lembrando que a campanha do Tet foi uma violenta ofensiva das forças militares do Vietnã do norte sobre o Vietnã do Sul.

Ainda nesse parágrafo, o trecho: "Ao mesmo tempo, uma outra ofensiva - de paz- se desenvolvia em diversas frentes” apresenta um paradoxo. Apesar de um recurso estilístico, visando a uma maior expressividade, tendo por base o agitado ano de 1968, compreende-se como verdadeiro, embora cause certa estranheza que manifestações que objetivavam a paz só conseguissem alguma repercussão numa forma combativa e agressiva.

Além das vozes esparsas, como já foi dito, muitos americanos pediam igualmente o fím da guerra. Como 1968 era ano de eleição nos Estados Unidos, o presidente da época, o senhor Lindon Johnson, via-se bastante afrontado, num ano que sua herança política seria colocada em causa.

Em uma matéria que pouco procurou explicitar as origens e os impasses do conflito, a revista, ao fazê-lo, deu voz, por meio do discurso direto, a Theodore Sorensen, que teria sido o mais íntimo conselheiro do presidente Kennedy. Vale ressaltar que o então presidente Lindon Johnson havia sido vice-presidente no governo Kennedy. Apesar de seu discurso ter o pretenso tom de um civil americano, é mesmo uma representação oficial, um pronunciamento que se mostrou por um lado um tanto quanto paternalista. Na realidade, uma maneira eufemística de não expor o caráter de fato imperialista: "Nossa ampla supremacia militar não pode produzir uma vitória e nossa ampla supremacia política não permite uma retirada”. Era a tentativa de justificar a manutenção da guerra. Seguiu o americano com a explicação: "Estamos incapacitados de transferir nossa responsabilidade aos sul-vietnamitas e sem possibilidade de anular os propósitos dos norte-vietnamitas". Os propósitos norte-vietnamitas citados eram o fechamento do cerco contra os americanos, o que, de fato, ocorreu, além da iminência de intervenção de outras nações comunistas, a U.R.S.S. ou a China. 
No que diz respeito ao intuito do jornalista, este, respaldado pela revista e em consonância com o senso comum, relativo ao assunto em questão, era convocar a sociedade, por meio de uma voz insinuante, com o objetivo de conseguir adesão popular e que esta tivesse eco suficiente para demover uma possível utilização de armas nucleares. Esse posicionamento, embora se coadunasse com a grande maioria, foi construído textualmente, de modo um pouco mais subjetivo, marca mais visível em textos elaborados por um sujeito 2, jornalistas e colaboradores, em geral, em textos do gênero comentário.

O gênero comentário nos leva a entendê-lo, muitas vezes, como um complemento de um texto do gênero relato. Este que é escolhido no meio jornalístico, diversas vezes, tendo em vista o curto espaço físico, se o texto é escrito, ou curto espaço de tempo, se o texto é veiculado pelo rádio ou pela televisão. Além de também ser uma estratégia ideológica de não se posicionar frente a um tema.

O trecho em que podemos verificar esse aspecto mais subjetivo se dá em: "Nenhuma análise é mais penetrante, nem mais inquietante, do atoleiro do Vietname do que estas poucas dezenas de palavras de Sorensen (...) a hipótese do emprego de armas nucleares no conflito deve ser afastada”.

O parágrafo seguinte tem por foco os números. Estes se referem às baixas, aos desaparecidos, aos inválidos. Em contrapartida aos números catastróficos apresentados pelo lado americano, o parágrafo seqüente mencionou que os números não pareciam tão alarmantes do lado dos norte-vietnamitas.

Para construir o ethos da imparcialidade, o jornalista desenvolve um parágrafo, em que não despreza nenhum dos lados envolvidos no confronto e assim inicia: "As cifras oficiais, de um e de outro lado, fazem parte do capítulo da guerra psicológica de todos os conflitos”. Finda então o parágrafo: “(...) se pudessem ser ouvidas as vozes de todas as pessoas que lêem jornais e revistas, ouvem rádio e assistem à televisão, horrorizadas que estão ante a violência das notícias, fotos e filmes que mostram detalhadamente o horror dessa guerra, é possível que elevasse de ateus, comunistas, capitalistas, militares, religiosos de todas as religiões um uníssono: “BASTA!”A palavra "basta”, em caixa alta, como já visto em Hernandes (2006), é a representação do que seria o som, o alto som do grito reproduzido graficamente. 
A última parte do texto verbal encontra-se na antepenúltima página da reportagem. $\mathrm{O}$ título é: "Hué: cidade arrasada". Como continuação do alerta do título do início, também este é escrito em caixa alta, em letra vermelha. É um único e pequeno parágrafo, poderia mesmo ser atribuído a esse texto o gênero de crédito de fotografia, uma vez que seu conteúdo limita-se a explicar, por meio de palavras, o verificado pelas imagens. Dito de outra forma, o atual estado da mencionada cidade, após ações militares: "Hué: a capital do antigo império aramita teve a maior parte dos monumentos de sua cultura transformada (...) em simples escombros". Vemos a antítese clara entre a "capital do antigo império", o que ratifica a importância do lugar, em detrimento de "simples escombros"; ou seja a cultura de um local reduzida a escombros.

Em linhas gerais, o texto apresenta uma situação clara e específica, o confronto já de anos entre os americanos e os norte-vietnamitas. No entanto, subliminarmente, a grande questão do momento passava mesmo pela divisão do mundo. Ou se estava do lado americano capitalista, ou contra eles, do lado comunista.

Não se pode negar que a imprensa de referência contribua fortemente para um posicionamento político-ideológico, que chega ao leitor indivíduo e, por encontrar eco, reverbera e torna-se uma voz e um pensamento coletivo. Dessa forma, o comunismo não era visto com bons olhos, especialmente no Ocidente, contudo, diante de tanta atrocidade, o posicionamento de solidariedade para com os civis vietnamistas, seja do Norte ou do Sul, era quase que inevitável. Assim, estes se apresentavam sob o ethos de vítimas, pessoas desamparadas, sem vez e sem voz, enquanto que tanto os americanos, o exército sul vietnamita e os vietcongs eram vistos sob a égide do ethos de desumanos. 


\subsubsection{O Cruzeiro, Ano XL- ${ }^{0} 31$ de 3 de agosto de 1968 .}

A capa da O Cruzeiro de agosto traz uma foto da miss universo Marta Vasconcelos que, pelo triunfo alcançado, viajou para Nova Iorque para cumprir uma agenda de compromissos. Juntamente com a foto, havia três manchetes: "Nossa Senhora volta a Natividade", "Quanto custa uma mulher" e "Uma rainha em Nova Iorque".

O sumário da publicação encontra-se na página 19 e está dividido em cinco partes: "Reportagens", "Futebol”, "Seções", "Humorismo" e "Política". Em "Reportagens", há dezenove itens com textos que vão da matéria da capa, a miss universo, a brasileira Marta Vasconcelos, uma entrevista com o noivo da beldade, assim como a miss com sua família e um outro texto em que se relatou o encontro de duas mães de duas misses com o mesmo nome Marta, uma era a Marta Rocha e a outra a Marta Vasconcelos. Na sequiência, há um artigo com dados relativos aos gastos mensais de uma mulher; a reportagem sobre o ataque do CCC na noite paulistana, além de outro texto sobre os passos da Igreja, frente ao contexto da época. Ainda sob a temática da fé, há uma reportagem abordando a suposta aparição de Nossa Senhora, no interior do Rio de Janeiro.

Essa primeira parte da revista trouxe ainda com uma reportagem contendo informações sobre a Tchecoslováquia pós Primavera e um longo texto sobre o Vietnã. No âmbito da cultura e da vida dos famosos, encontramos um texto que abordava a história de amor de Agnaldo Rayol; um outro artigo sobre a grande produção artística de Ziraldo; uma reportagem sobre a cantora grega erradicada na França, Dalida; um texto bastante literário, produzido por José Cândido de Carvalho, com um perfil do ex-presidente mineiro Juscelino Kubitschek; um artigo sobre a novela "Antônio Maria" e uma reportagem ricamente ilustrada com muitas fotos sobre um novo tipo de circo, impulsionado pela eletrônica, num jogo de luz e música. Com a temática da água, vimos dois textos, um em que se enfocou o problema do abastecimento de muitas cidades, em especial do estado de São Paulo e um outro enaltecendo a natureza das Cataratas do Iguaçu. No primeiro artigo, verificamos o que popularmente muitos chamam de matéria "chapa-branca", em virtude de seu

posicionamento. A reportagem, de certa maneira, esteve a serviço do enaltecimento das 
soluções propostas pelo governo do estado de São Paulo, para o problema de abastecimento de água.

No que se refere a questões ligadas à economia, encontramos um texto apologético, fazendo propaganda de Minas Gerais, como sendo um local promissor e, assim trouxe informações de investimento naquele estado. Encontramos um outro texto, cujo tema era a moeda local e seu valor e, por fim, uma reportagem sobre eletrificação no estado de Alagoas. Apesar desse item "Reportagens" vir seguido do item "Futebol", houve ainda, naquele item, um outro texto acerca dessa temática: "No Clássico, Remo venceu Paissandu".

No item propriamente intitulado "Futebol", encontramos quatro textos, dos quais três eram entrevistas, todos diziam respeito à longa viagem da seleção brasileira de futebol, por vários países, a fim de observar melhor os jogadores que disputariam a copa de 1970.

Em "Seções”, encontramos horóscopo; duas páginas sob o título de "Em Confiança", em que se apresentaram pequenos textos relativos a pessoas conhecidas, como artistas e jogadores de futebol, o consagrado lugar destinado a charges; notícias sobre eventos em que compareceram funcionários dos Diários Associados, empresa proprietária de O Cruzeiro e onde estiveram presentes outras celebridades do mundo artístico, esportivo e político; além de em "Seções" haver dicas de culinária, uma crônica de Austregésilo de Athayde e cartas do leitor e suas devidas respostas.

Em "Humorismo", encontramos pequenos textos, do gênero "casos"; mais charges; uma crônica de Stanislaw Ponte Preta e uma página destinada ao famoso "Amigo da Onça”. No último item, "Política", há apenas um texto em que se discute uma possibilidade de diálogo entre a oposição constituída pelo MDB, Movimento Democrático Brasileiro e o governo.

Nessa página do sumário, encontramos a reprodução da foto da capa, além de uma outra pequena foto e um texto em que se menciona a vida pessoal de um cantor, Gutemberg, que se fez conhecido do dia para a noite e, assim como surgiu do anonimato, para lá voltou, sumiu da imprensa e da música, logo após seu casamento. O sumiço foi por pouco tempo. Alguns anos depois, formou o importante trio Sá, Rodrix e Guarabira, precursores do rock rural no Brasil.

Para seguir com o padrão adotado, passaremos a uma descrição da matéria relativa à capa da revista. O presente número, como um recurso habitual, elegeu para a capa mais 
uma moça bonita, dessa vez, ninguém menos que a miss universo, a brasileira Marta Vasconcelos. Como chamada de capa: "Uma Rainha em nova Iorque".

Logo na primeira página da revista inicia-se a matéria referente à capa. É uma reportagem assinada, que consta de sete páginas. O plano de conteúdo é construído juntamente com o plano de expressão, são muitas imagens. Somam-se doze fotos, algumas ocupam toda a página. A totalidade das fotografias, de acordo com sua função no texto, é a de registro. Auxiliam na abordagem do assunto, mostram o sucesso da miss que "seduziu" Nova Iorque.

A página inicial da reportagem traz uma grande foto da miss Marta Vasconcelos, em traje de banho, tendo ao fundo um cenário cosmopolita, um resumo do que é a metrópole Nova Iorque. O pequeno texto ao lado da foto apresenta-se mais como gênero crédito de foto e traz o nome dos colaboradores, que elaboraram a matéria. Indalécio Wanderley e Luiz Alfredo. A segunda página da reportagem é composta unicamente por uma foto da miss, em traje de passeio, sentada diante de uma fonte. A página três apresenta três fotos. $\mathrm{Na}$ primeira, a miss conversa com Edílson Varela, homem que coordenava o miss Brasil. $\mathrm{Na}$ segunda foto, a moça pousou perto de pessoas que a reconheceram no aeroporto. $\mathrm{Na}$ terceira foto, a jovem está em pose casual, simulando um passeio pela cidade. Também nessa página, o pequeno texto que serve como crédito, para elucidar os momentos e situações relativas a cada uma das fotos.

Nesse início do texto verbal, o plano de conteúdo é construído tanto sob a perspectiva especialmente do sujeito 2, a equipe jornalística responsável pela matéria, como pelo próprio sujeito 3, no caso Marta Vasconcelos. Há a reprodução, em discurso direto, de alguns enunciados proferidos pela miss. São frases que parecem entrecortadas, como se fossem respostas a perguntas feitas, tal qual respostas a uma entrevista, sem dúvida um gênero que, mesmo não explícito no artigo, ajudou na composição geral da reportagem.

Apesar de as falas se mostrarem como fragmentos, compõem o perfil de alguém ao mesmo tempo encantada com o que havia conquistado e, por outro lado, tendo que pagar um certo preço pelo destaque alcançado. O preço era a atribulada agenda de compromissos em Nova Iorque, em conseqüência, afirmou: "Muito cansativo para mim, que estava habituada a uma vidinha tranqüila”, além da ausência da família e do noivo. Tudo isso tendo por conseqüência a confissão da jovem: "Estou cansada”, “louca para voltar. E 
saudosa, principalmente"; "Seria ótimo se ele pudesse estar aqui comigo, passeando comigo, conhecendo comigo esta grande cidade".

A quarta página da reportagem apresenta duas fotos, uma que ocupa meia página e uma menor, abaixo de outro pequeno texto, cujo título é "Dela, o encanto e saudade". A estrutura textual de mescla de sujeito 2 , o jornalista e de sujeito 3 , no caso a miss, continua, com mais alguns trechos da fala de Marta, apresentados em discurso direto.

"Todos são muito gentis. Adultos e crianças. Fazem-me parar na rua, conversam comigo, dizem coisas amáveis. Estou cansada, é certo, mas encantada, também”. O jornalista, de forma claramente subjetiva, traça um breve perfil da moça, em que a qualifica como sendo uma pessoa alegre, saudável, extrovertida. "É um ótimo garfo". A partir dessa menção a um gosto particular da miss, estabelece uma relação entre o tempero americano, o baiano e a saudade de Marta Vasconcelos, em especial do vatapá, quase um sinônimo de sua terra natal, a Bahia.

A quinta página traz apenas uma grande foto de Marta brincando com uma criança, nas ruas de Nova Iorque. A sexta página traz uma foto que ocupa dois terços e a parte final do curto texto verbal da matéria, com informações de que recebeu flores e telegramas de congratulações, até do governador da Bahia. A moça disse ter ficado impressionada com a altura dos prédios, uma comprovação de provincianismo. Somando-se as características da moça, foi possível o leitor construir o ethos da nova miss universo, aliás, um ethos que ressaltava seu lado ingênuo e mesmo infantil, confirmado até pelo tipo de presente escolhido para levar aos irmãos: chicletes. A última página é composta por três fotos da moça, sendo uma de maiô, com um alto prédio ao fundo.

Antes de iniciarmos nossa próxima análise, cumpre-nos justificar nosso critério de escolha da reportagem. De cunho político, havia algumas opções: o texto sobre o ataque do CCC em São Paulo; a matéria cujo enfoque era o posicionamento da Igreja, na dita hora da decisão; um outro texto com informações sobre a Tchecoslováquia depois da "Primavera de Praga"; um longo texto sobre a ocupação do território do Vietnã, desde a Idade Média, bem como algumas estratégias de guerra tomadas por ambos os lados, a situação vivida pelos civis e soldados envolvidos no massacre duradouro, além de números trágicos dos anos de luta e, no item "Política", a reportagem em que se aventava um possível diálogo entre o partido de oposição, o MDB e o governo militar. 
Eliminamos a perspectiva de analisar o texto sobre a Igreja, uma vez que seu foco não era o conturbado momento político vivido no Brasil, mas sim um posicionamento e resoluções, em virtude da reunião da CNBB. Descartamos também o artigo sobre a Tchecoslováquia, por já termos explorado o tema em duas outras revistas. Por esse mesmo motivo também resolvemos não focar nossa análise do texto referente ao Vietnã. Por fim, apesar do título da seção ser "Política", o conteúdo do texto ficou mais a cargo de uma possível negociação entre o partido de oposição e o poder militar. Para explorar mais esse regime ditatorial e suas reprováveis ações, julgamos que a reportagem, abordando o chamado "Comando de Caça aos Comunistas", ser-nos-ia uma melhor referência dadas as várias vozes nele encontradas, além de marcas ideológicas importantes, uma forma de reiterar nossa opção por textos de cunho político.

Passaremos à nossa análise, na seqüência da reprodução do texto apresentado na revista. 


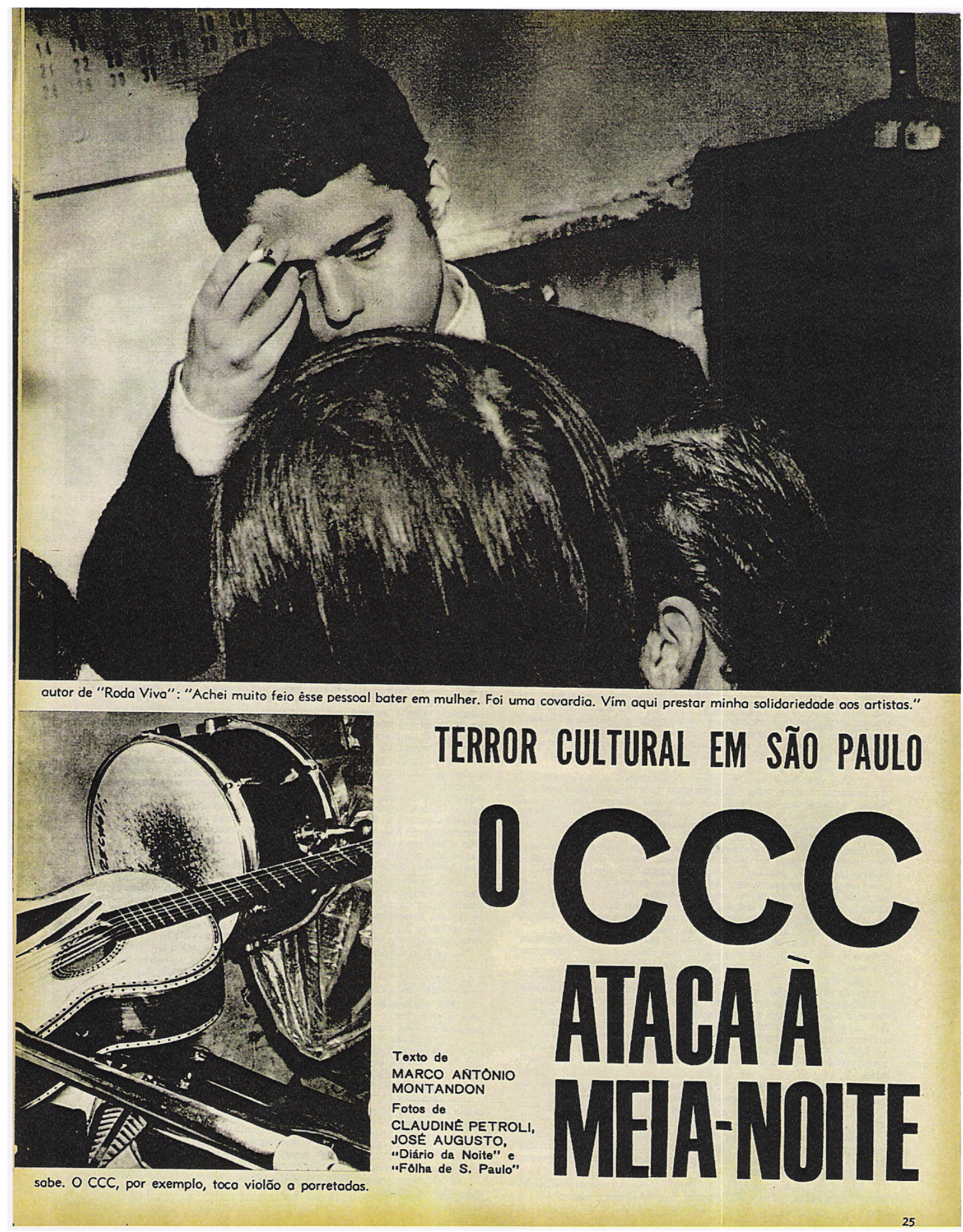




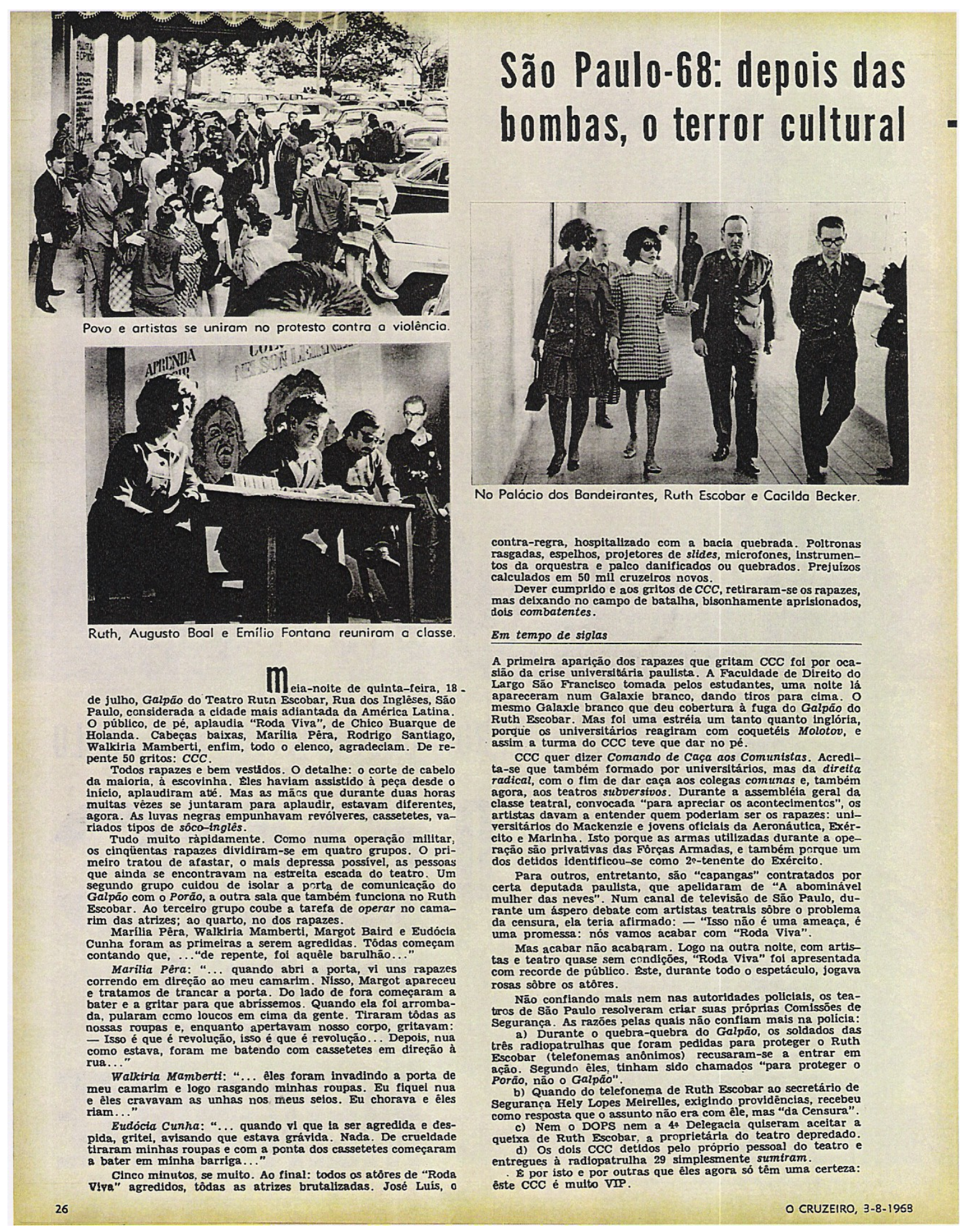




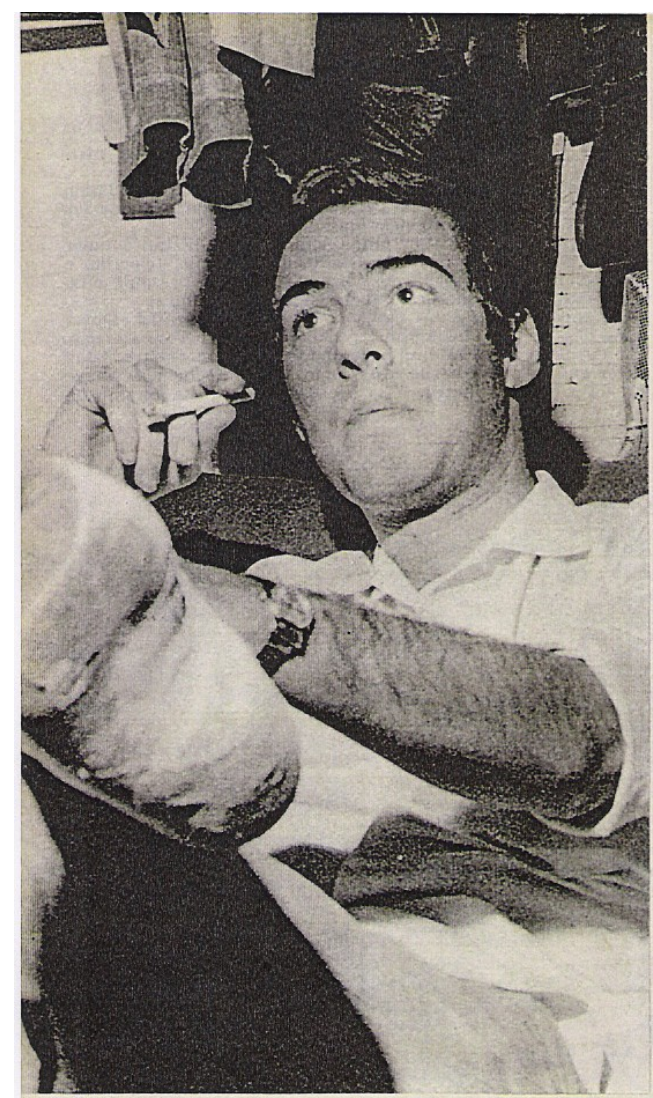

Fábio Camargo, ator. Ganhou palmas e pauladas do CCC

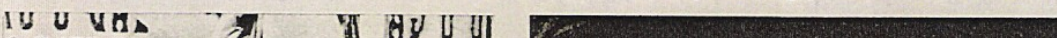
IU U Y RAT
DSES. 209-FONE 35.8843
ESES

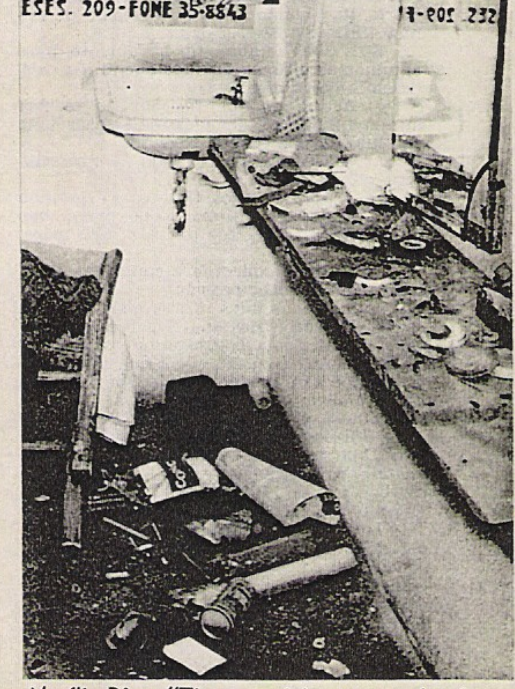

Marilia Pêra: "Tiraram minha roupa e depois me bateram com cossetetes. Eles pareciam loucos".
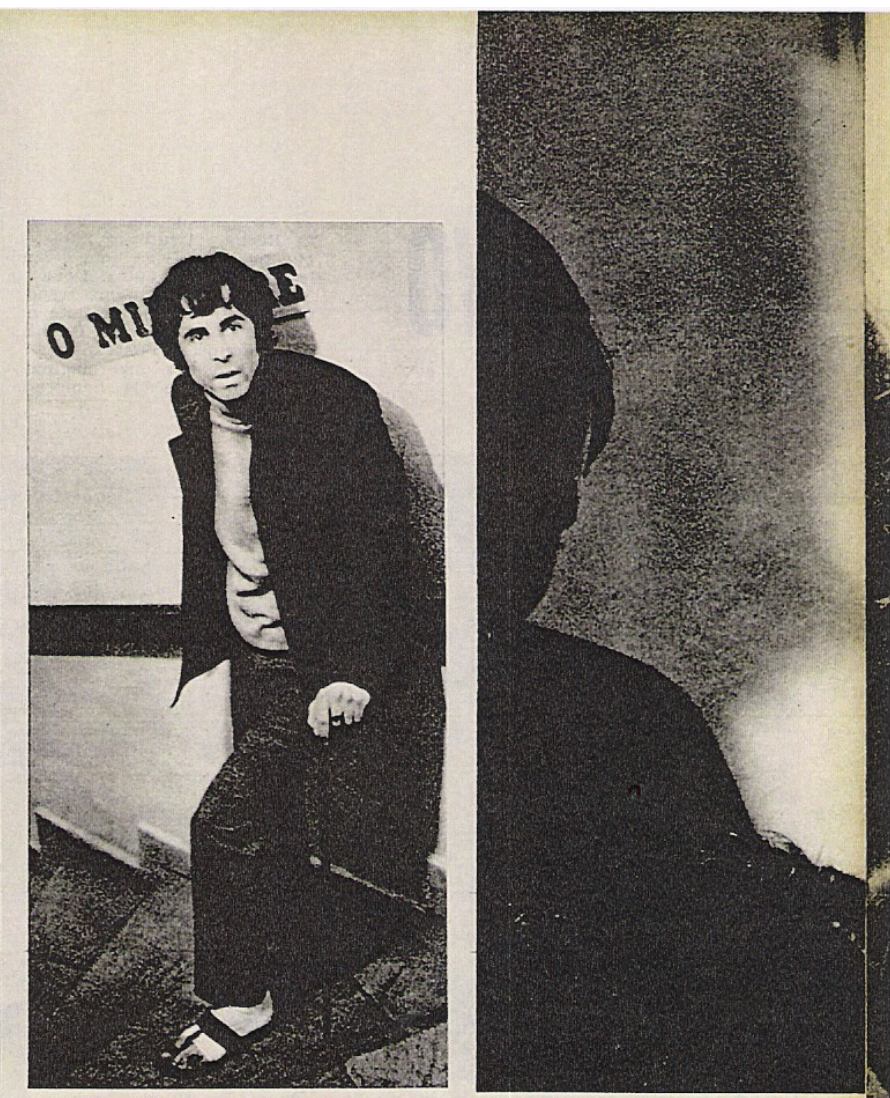

De Chico Buarque de Holanda,

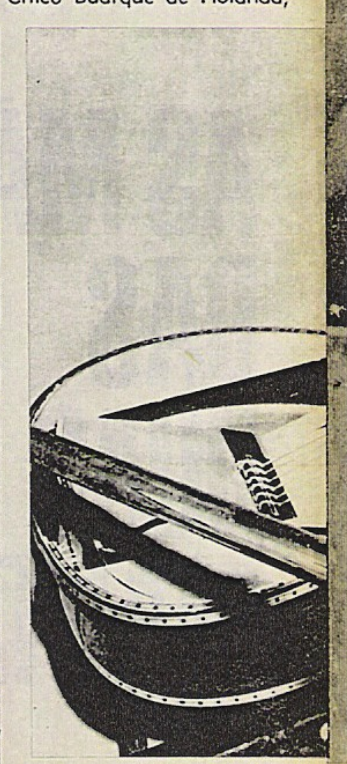

Cado um toca conforme O CRUZEIRO, 3-8-1968 
“Terror cultural em São Paulo - O CCC ataca à meia-noite”. A reportagem conta com três páginas. É um texto assinado por Marco Antônio Montandou e fotos de Claudinei Petroli e José Augusto. Novamente nos deparamos com a riqueza, em termos do plano de expressão visual. Somam-se, nas três páginas, nove fotografias. As duas primeiras páginas são compostas unicamente com seis fotos e seus devidos créditos.

O texto verbal concentra-se na terceira e última página da matéria e é ainda ilustrada por mais três fotos menores. A essa composição global do texto, quer em seu plano de expressão como no de conteúdo, não descartamos ser um posicionamento político ideológico pretensamente menos explícito, como um recurso que tanto permitia que o leitor continuasse com a crença numa revista cujo ethos se consolidava pela imparcialidade, ao mesmo tempo em que se exibia como destemida, a fim de informar sobre a realidade dos fatos. Ou seja, uma empresa que cumpria seu primordial papel. Sob outra perspectiva, a do governo, representado pelos órgãos de censura, poderia ser vista também sob o ethos da imprensa que apenas segue com sua função, como uma imprensa que não se colocava tão contrária às ações militares, ao menos pelo pouco espaço e aprofundamento do artigo relativo ao episódio ocorrido no Galpão do teatro Ruth Escobar, em São Paulo.

Como o texto é assinado e contou com o apoio de dois fotógrafos, a voz clara é a do sujeito 2 a do jornalista e a voz silenciosa, mas tão importante quanto a do jornalista, a dos fotógrafos. Os profissionais envolvidos no artigo procederam a uma escolha tanto do tom, das palavras para compor a textualidade, assim como das fotos, a fim de compor um plano de expressão sincrético. Relativo a esse sincretismo da linguagem, Discini (2007, p. 57) assevera:

Um texto (...) pode ser analisado como junção de dois planos: o do conteúdo e o da expressão. No plano do conteúdo estão as vozes em diálogo, está o discurso. No plano da expressão está a manifestação do sentido imanente, feita por meio da linguagem sincrética, que integra o visual e o verbal sob a única enunciação.

Além do sujeito 2, há a voz de vários sujeitos 3, personagens envolvidos nos acontecimentos, e vozes de pessoas anônimas ou muito conhecidas, como a de Chico Buarque, solidárias com as vítimas da invasão no galpão do teatro Ruth Escobar. Ainda que implícita, não se pode dizer que o sujeito 1 , no caso a própria revista não esteja, de algum 
modo presente, já que é um veículo da informação dada. O repórter fala do lugar de um profissional do jornalismo, mas também sob a perspectiva de um civil, indignado com as ações condenáveis do CCC. Os atores falam da perspectivas de vítimas, outros artistas se manifestam tanto como civis escandalizados, como pessoas de visibilidade no meio artístico, com a responsabilidade de se solidarizar com os colegas do meio artístico.

Quanto à organização do texto, a oposição claramente detectada se dá, por um lado, pelos artistas contrários ao regime militar e seus desmandos, por outro, os militares a serviço da ditadura imposta já desde 1964, que, aos poucos foi se mostrando mais cerceadora e o ano de 1968 marcou o início do que se chamou "linha dura" do regime militar, a partir do governo de Costa e Silva, o começo dos "Anos de chumbo".

Em relação às fotos, em mais uma análise vemos o predomínio das fotos de registro, aquelas que auxiliam na composição do plano de expressão, a fim de ilustrar melhor o fato em questão. Consideramos quatro as fotos apresentadas na primeira página, apesar de outras duas estarem divididas entre a primeira e a segunda página. A primeira foto tem por crédito: "Fábio Camargo, ator. Ganhou palmas e pauladas do CCC". A segunda foto traz Rodrigo Santiago que, conforme os créditos, era "vítima do terror". Nessas fotos, ambos apresentam-se com os pés machucados. Segundo Hernandes (2006), tratam-se de fotos de registro, uma vez que reiteram a violência sofrida na fatídica noite. A terceira foto apresenta um camarim completamente destruído, outro retrato da violência e, por último, a quarta foto, em que se vê, parcialmente, o rosto de Marília Pêra e nos créditos: "Tiraram minha roupa e depois me bateram com cassetetes. Eles pareciam loucos”.

A segunda página traz, além do título o nome dos autores da reportagem e duas fotos, a maior e de mais destaque traz, ao centro, Chico Buarque, com aspecto bastante sério e preocupado. Nos créditos há a reprodução literal do dito por Chico Buarque, ou seja, é mais uma voz presente no texto. Uma voz que ajuda a compor o coro contrário à ditadura militar: "De Chico Buarque de Holanda, autor da Roda Viva: "Achei muito feio esse pessoal bater em mulher. Foi covardia. Vim aqui prestar minha solidariedade aos artistas”. Por fim, a última foto em que se vêem instrumentos musicais quebrados. "Cada um toca conforme sabe. O CCC, por exemplo, toca violão a porretadas".

Um importante recurso lingüístico, o verbo "tocar" apresenta-se no contexto como ambíguo. Sob a perspectiva de quem explora musicalmente um instrumento e sob a 
perspectiva de quem "toca" (taca, na forma coloquial) um objeto qualquer no chão, ou contra algo, com o intuito de destruir, no caso a destruição dos instrumentos musicais.

Para reforçar ainda mais a atitude bárbara, outra palavra é usada "porretadas", com a função de advérbio de modo. Em outras palavras, o jornalista usou a ironia para mostrar alguns resultados da ação do $\mathrm{CCC}$, resultados que foram menos devastadores para os instrumentos do que para as pessoas vítimas da arbitrariedade do grupo.

Na terceira página da reportagem, encontramos o subtítulo: "São Paulo- 68: depois das bombas, o terror cultural”. Em destaque, no início da página, há três fotos. A primeira cujos créditos são: "Povo e artistas se uniram no protesto contra a violência”, em que se vê um grande número de pessoas na rua, provavelmente em frente ao teatro onde se deu a invasão. Não eram só pessoas comuns, eram vozes que se misturavam afinadamente e ganharam um tom mais melódico, tendo como primeira voz a dos artistas.

A segunda foto reúne uma nata de artistas intelectuais de referência: "Ruth (para se referir à Ruth Escobar), Augusto Boal e Emílio Fontana reuniram a classe" e, por último, a foto de duas importantes atrizes, juntamente com dois militares e sob esta os créditos: "No Palácio dos Bandeirantes: Ruth Escobar e Cacilda Becker”. Com o intuito de protestar contra a barbárie sofrida no teatro, um recurso escolhido, provavelmente de forma conjunta pelo meio artístico, foi designar duas mulheres de personalidade e de grande representatividade, graças às suas atuações no teatro e na TV. Foi uma estratégia para tentar visibilidade e apoio popular, contra o que seria muito delicado para o governo combater.

No que se refere ao que deu maior destaque à reportagem, temos o plano da expressão com as fotos e seus créditos. Estas expressam claramente todos os personagens envolvidos e o posicionamento comum a todos, diante dos acontecimentos. Mais uma vez vemos a comunhão sincrética da linguagem entre o plano de conteúdo, um pouco menos expressivo, e o plano de expressão. O texto está dividido. Na primeira parte, temos nove parágrafos e, por meio da reprodução, em discurso direto, enunciados que foram proferidos numa tentativa de franco diálogo, todavia, mais que um diálogo, pelo calor dos acontecimentos, além de um coro bastante afinado contra a covardia de que tinham sido vítimas, vislumbramos uma explícita polifonia.

No início do texto, o repórter utiliza o plano discursivo da enunciação, relata o ocorrido e, para tanto, recorre aos dêiticos de tempo: "meia-noite de quinta, 18 de julho", como de 
lugar: "Galpão do teatro Ruth Escobar, rua dos Ingleses, São Paulo". Para enfatizar o efeito de surpresa, o jornalista atribui ainda a São Paulo o adjetivo de "cidade mais adiantada da América Latina”. Ou seja, supõe-se que em lugares mais desenvolvidos atos bárbaros não aconteçam ou, pelo menos, não deveriam acontecer. $\mathrm{O}$ trecho segue com uma estrutura típica da narrativa, já que os elementos fundamentais desse tipo textual, como tempo, espaço, personagens, no caso o público, que aplaudia a encenação da peça "Roda Viva", de Chico Buarque, além dos artistas da referida montagem; o narrador e a síntese do que seria desencadeador de ações seguintes: "De repente 50 gritos: $C C C$ ". Ou seja, com esse quase "grito de guerra", nada mais que o esperado ocorreu, um tumulto generalizado.

A fim de expor a ação como covarde, o autor apresentou detalhes, que não contextualizados, pareciam informações irrelevantes. Essa descrição física dos agressores permite a leitura de que estes não eram pessoas desqualificadas, comuns, baderneiros sem um propósito. Eram jovens que não invadiram sorrateira ou abruptamente o galpão do teatro ao final do espetáculo, mas estiveram presentes o tempo todo, pagaram para assistir à peça e inclusive engrossando o som dos aplausos em alguns momentos. "Todos rapazes e bem vestidos (...) corte de cabelo (...) à escovinha (...) haviam assistido à peça (...) aplaudiram até". O uso da preposição "até" é uma maneira de reforçar o caráter premeditado de toda a ação.

O tom de narrativa segue, com os recursos conhecidos, para manter a atenção do leitor e, para tanto, o repórter foi (re) construindo, aos poucos, a cena, de forma bastante similar a de autores ao intentarem compor uma atmosfera de suspense que conjumina, normalmente, num clímax, uma situação extrema, para depois de um intervalo de tempo, haver um inevitável e, no caso imprevisível desfecho e finalização do fato.

Montandon compara a mãos desses jovens do CCC, em dois momentos: "Mas as mãos que durante duas horas muitas vezes se juntaram para aplaudir, estavam diferentes (...) As luvas negras empunhavam revólver, cassetetes (...) sôco-inglês”. O uso da conjunção adversativa "mas", no início do período, já traz explícita a marca de oposição. Houve uma mudança de procedimentos daquelas mesmas mãos que antes tinham aplaudido e que passaram a desferir contra as pessoas que tinham sido alvo de seus falsos aplausos.

No terceiro parágrafo do texto, pela descrição do ocorrido, percebeu-se a ação planejada, a ponto de os homens do "CCC" prontamente se dividirem e partirem, de forma 
rápida e eficaz, para a concretização do plano. O quarto parágrafo enumerou as atrizes, as primeiras vítimas da agressão. Há no trecho uma reprodução, em discurso direto, do que tinha sido proferido conjuntamente: “de repente, foi aquêle barulhão...” Vemos essa voz coletiva das atrizes que falam sob a perspectiva de quem sofreu uma inesperada violência.

Nos três parágrafos seguintes, o repórter optou por dar a voz a três atrizes, com a reprodução de seus pronunciamentos frente ao ocorrido. No fragmento, além da voz da atriz, Marília Pêra também utiliza-se do discurso direto e contou que os agressores disseram: “Isso é que é revolução, isso é que é revolução...” Segundo a atriz, a violência seguiu, com ela recebendo golpes de cassetetes, mas tendo que se encaminhar, nua, para a rua .

$\mathrm{Na}$ reprodução da fala de Walkíria Mamberti, o relato também mencionou o primeiro ato dos agentes do CCC: despirem as atrizes, agredidas, sem piedade alguma: “Eu chorava e eles riam...” A atriz utilizou, em sua construção textual, figura de linguagem paradoxo, delimitando bem os limites de um e do outro lado da ação. Eudócia Cunha relatou que ao se dar conta da situação, avisou que estava grávida, o que só serviu para demonstrar, ainda mais a covardia da ação: "Tiraram minhas roupas e com a ponta dos cassetetes começaram a bater na minha barriga..."

O penúltimo parágrafo apresentou o saldo da barbárie com "atrizes brutalizadas, contra-regra (...) com a bacia quebrada", além dos danos no teatro e em equipamentos. A primeira parte do texto é finalizada com um curto e contundente parágrafo: “Dever cumprido e aos gritos de CCC, retiraram-se os rapazes, mas deixado no campo de batalha, bisonhamente aprisionados, dois combatentes."

A parte final do texto apresentou-se com "Em tempo de siglas". São cinco parágrafos. No primeiro, vemos a referência a um outro fato transcorrido, a primeira aparição dos rapazes do CCC. Para essa menção, há o uso do plano histórico a enunciação, com os verbos no pretérito perfeito, além do uso do particípio, em "tomada pelos estudantes". Fora essa referência aos ditos rapazes do CCC, a pista: o mesmo Galaxie branco utilizado no Largo São Francisco, durante a crise universitária paulista. Nessa segunda vez, o carro ajudou os agentes a evacuarem rapidamente o Galpão do teatro Ruth Escobar. 
O segundo parágrafo elucida a sigla CCC, Comando de Caça aos Comunistas e hipóteses de que eram os integrantes: “(...) universitários (...) mas da direita radical (...) para os artistas, eram "universitários do Mackenzie e jovens oficiais da Aeronáutica, Exército e Marinha.”A suposição tinha sentido, já que “as armas utilizadas (...) são privadas das Fôrças Armadas, e (...) porque um dos detidos identificou-se como segundo tenente do Exército”.

O trecho merece destaque pela escolha lexical, que configura, em termos de materialidade lingüística, como marca ideológica dos agressores e seus objetivos. "Universitários da direita radical". A palavra "direita", no trecho, é um substantivo que é acompanhado de um adjetivo "radical". Ser de direita, para os jovens engajados, era um posicionamento consubstanciado por questões que envolviam poder, injustiça, força, inflexibilidade, associado ao adjetivo "radical" simbolizava, em especial num ano tão marcado por ecos de liberdade, paz e justiça, como "fora de moda", antiquado, reacionário. Todavia, não podemos afirmar que esse posicionamento ideológico fosse o comum na revista e próprio de seus leitores, de forma geral.

$\mathrm{O}$ adjetivo "comuna", escrito em itálico é tanto uma ironia, em especial por ser utilizado ao lado do cordial substantivo "colega". Como outro uso de destaque, vemos o adjetivo "subversivo", também em itálico, para qualificar o teatro. Ou seja, as peças que não seguiam os cânones de um espetáculo mais padrão, em que se discutiam questões da ordem do dia, eram taxadas de subversivas. Palavra, aliás, bastante explorada durante toda a ditadura, em variados discursos dos militares e seus comparsas.

O terceiro parágrafo segue com hipóteses sobre quem eram os temidos agentes do CCC. Havia quem aventasse a possibilidade de serem "capangas", a mando de uma "certa deputada paulista", cujo apelido era "A abominável mulher das neves". Vemos no trecho a voz reproduzida da mencionada deputada: "Isso não é uma ameaça, é uma promessa: nós vamos acabar com "Roda Viva". Nesse enunciado, a deputada fala unicamente sob a perspectiva do poder instituído, em consonância com o discurso militar.

O parágrafo seguinte relata que o desejo e promessa da deputada não tinham chegado a bom termo, já que: “(...) na outra noite, com artista e teatro quase sem condições, "Roda Viva” foi apresentada com recorde de público”.O último parágrafo apontou a consequiência do ocorrido, os teatros de São Paulo criaram comissões de 
segurança, uma vez que não confiavam na polícia. O jornalista, para reforçar a descrença que se abateu sobre a polícia, enumerou motivos para isso: os guardas das radiopatrulhas recusaram-se a entrar no Galpão do teatro; Ruth Escobar, ao exigir ações após a invasão, teve como resposta do Secretário da Segurança de que era algo que não competia a ele; o DOPS e a $4^{\circ}$ delegacia não aceitaram a queixa de Ruth Escobar sobre a depredação do teatro e os "dois CCC detidos pelo próprio pessoal do teatro e entregues à radiopatrulha (...) sumiram".

Como uma estratégia de ironia e recuperando o início da segunda parte do texto, em

que se fala em sigla, a matéria é finalizada pelo autor: "É por isto e por outras que eles só têm uma certeza: este CCC é muito VIP”, sigla que significa "very important person". A finalização do texto é eficaz para a construção do ethos de nefasto, arbitrário, violento no que se referia, num primeiro momento, ao CCC, mas de forma mais global a quem esse comando estava subordinado. Assim, sem muito poupar o governo militar e o estado de atenção pelo qual a sociedade estava submetida, o repórter expõe e ataca "a face" da ditadura que começava a se mostrar mais devastadora, contudo oficialmente instaurada. 


\subsubsection{O Cruzeiro número 37 , ano XL, de 14 de setembro de 1968 .}

A capa traz um foto grande e cinco manchetes. A primeira reportagem apresentada: "Ser ou não ser professôra" é ilustrada justamente pela foto da capa, em que se vê uma jovem moça, com ar pensativa, vestida com uma camisa branca, o que deveria compor o uniforme da normalista. Essa hipótese é ainda reforçada pelo broche que a moça usava, com iniciais que deveriam ser em referência à escola em que estudava. As demais manchetes são: "A Igreja traída", "Mulato: um negro branco", "Especial - Caderno Ceará" e "Índia: no mundo da magia". Apesar de na capa haver o mais comum para o Cruzeiro, ou seja, uma bela moça, essa não era conhecida, uma artista ou estava em voga na sociedade. Era o reflexo da incredibilidade de jovens moças que, mesmo com diploma de professora, decidiram não ficar na Educação.

Como o comum às revistas, o sumário traz o conteúdo da publicação, dividido em partes. O presente número traz esse índice apenas na página 19, após duas reportagens: "Ele aprendeu a andar nas areias do Saara" e "Chile, o ponto mais alto do continente". Nessa página que sintetiza a revista, encontramos três pequenas fotos, do lado esquerdo da página, em referência a três matérias: "D. Hélder Câmara, o pastor da angústia", "Mulato: um negro branco" e "Estudantes: protestos em Brasília e São Paulo". Na parte de baixo da página, do lado direito, há outra foto, a mesma que ilustrou a capa, entretanto, no índice a foto é bem pequena e está em preto e branco. A reportagem relativa à foto é: "As professoras não têm escolas". A revista estava dividida em três partes: "Reportagens", com vinte e quatro itens; "Seções", com seis itens e "Humorismo", com cinco itens.

Em "Seções", houve um outro texto que nos fez pensar na possibilidade de trabalhar com ele. Este era assinado pelo articulista Theophilo de Andrade e trazia por título: "O beijo de Judas". Embora versasse sobre a figura do presidente da URSS, Brejnev, também se referia à "Primavera de Praga". Todavia, pela estrutura, o texto seguia as marcas do gênero comentário, escrito em primeira pessoa e forte aspecto subjetivo, ao mencionar as postura de Brejnev, que se assemelhava a de Judas, uma vez que, segundo o jornalista, o presidente traiu seu pares. 
Como procedemos anteriormente, exploraremos, de maneira menos detida a reportagem cujo assunto foi escolhido para capa da revista. Na sequiência, selecionamos um texto, cujo teor é, também como os outros, voltado para a política. Neste número, encontramos algumas matérias com esse conteúdo, a saber: "Ho Chi Minh no Brasil", a que dispensamos por ser mais um relato de um brasileiro que teria vivido com o então futuro presidente do Vietnã, na Rússia, alguns anos antes. O texto seguinte era bastante longo, ocupando trinta e cinco páginas e se intitulava: "Caderno Especial Ceará", julgamos ser o artigo uma grande e detalhada propaganda do governo Plácido Castelo, assim, também descartamos esse texto. Na sequiência, deparamo-nos com: "Guerrilha jovem em Chicago", em que se abordava a grande manifestação de jovens hippies e militantes do Partido Internacional da Juventude. O evento ganhou repercussão, por ter ocorrido durante a convenção do Partido Democrata. As reivindicações centrais diziam respeito à liberalização da maconha e contestavam a continuidade da Guerra no Vietnã. Por ser uma manifestação mais isolada e com fins específicos, também achamos por bem não explorá-la.

Nosso impasse ficou relativo a um tema bastante importante da política nacional, envolvendo alunos universitários em Brasília. A matéria tinha por título: "Estudantes: protestos em Brasília e em São Paulo. Apesar da relevância do tema, ainda mais no período tratado, optamos mesmo por explorar uma notícia internacional, até para tentarmos traçar um paralelo entre as revistas brasileiras e portuguesas, uma vez que o assunto também nesta edição ganhou destaque. Então, optamos por explorar a reportagem “Tchecoslováquia invadida".

Principiamos uma visão panorâmica do número, a partir da reportagem da capa: “A Professôra precisa de escola e a escola precisa de professôra". O texto é assinado, ocupa seis páginas, das quais duas são destinadas apenas a fotos. Há, ainda, outras duas páginas quase que inteiramente ocupadas por outra grande fotografia. Somam-se sete fotografias. A primeira foto é a chamada foto síntese, por representar, de forma expressiva, a relação com o assunto central abordado. Os rostos satisfeitos das crianças contrastam com o aspecto compenetrado da senhora na janela, provavelmente, a professora da turma. Apesar de as crianças parecerem felizes, devem ser pobres, inferência levantada pelas vestimentas, aliado ao fato de se verificar somente uma criança calçada. 
A reportagem apresenta uma organização em que se vê a oposição "ser professora" e ter que se submeter à situação caótica da educação e, mesmo com o título de professora, "optar por outra atividade" profissional, menos penosa. Essa oposição pode até ser representada, contrastando a primeira foto com a segunda, em que se vê a jovem recém professora, vestida de: “mini-saia amarela, (...) as botas vermelhas de cano longo, dá os últimos retoques nos cabelos e no baton, e põe o anel de professora (...) sai para o trabalho - de recepcionista num posto de gasolina”. Essa foto é a chamada de registro, uma forma de ancoragem do texto, aliás, esse tipo de ancoragem será possível notar também nas fotos seguintes.

A terceira e a quarta foto mostram crianças sentadas no chão, descalças, curvadas sobre os cadernos, o retrato de descaso e precariedade da educação. Essas imagens contrastam, novamente, com outra foto, a quinta, em que a mesma jovem parece conversar, satisfeita, com um cliente do posto onde trabalha. Essa estratégia de opor a realidade cruel da educação com o sorriso satisfeito de quem optou por não seguir o tão proclamado sacerdócio continua nas duas últimas páginas da reportagem.

A sexta foto traz um close da ex-futura professora, alegre e a sétima fotografia mostra uma longa fila de alunos indo ou vindo da escola. Essa última foto é menos dramática do que as anteriores, que retratavam escolas, nesta última são fotografadas meninas devidamente uniformizadas e calçadas.

No que diz respeito à parte verbal, percebemos o verbo no presente, na passagem em que o texto assume uma estrutura mais próxima do gênero relato cotidiano. No mesmo momento em que a moça saia para trabalhar, "milhões de crianças de azul e branco cantam o Hino Nacional nas 130 mil escolas espalhadas por todo o Brasil”. Essa prática de canto era comum em várias épocas, quase tido como um requisito para as escolas, em especial as oficiais durante a Ditadura Militar.

A oposição no texto não se dá entre a moça que decidiu não atuar como professora, mas com cinco milhões de meninos e meninas que, do lado de fora olham tudo com inveja. Há a elipse da palavra "escola", no trecho, recuperável pelo contexto. A matéria segue desconstruindo o que seria um sonho para esses milhões de crianças com o sonho de que a escola fosse o lugar não só do conhecimento, mas quase um passaporte para um futuro bom. 
Para isso, o recurso utilizado pelo sujeito 2, o jornalista Archibaldo Figueira, foi afirmar não ter a escola muito a se invejar e enumera os problemas comuns da educação oficial, a começar pela evasão escolar, o fato de escolas terem à frente professores improvisados, em referência ao que se chamava de professores leigos ou seja, os não formados. A lista de problemas continua com a falta de material, mesmo o básico como carteiras, além dos salários baixos dos professores.

A quarta página da reportagem traz um título forte: "Nota zero para o ensino primário". Aqui, nota-se o recurso de busca de expressividade, a partir do tema central tratado. Em outras palavras, é do mesmo campo semântico da escola, da educação, a nota, mesmo sendo zero. O texto, nessa página, inicia-se por um parágrafo em que há apenas um único e longo período, com dados relativos aos professores sem formação e a conseqüência disso.

Na seqüência, há dados precisos da evasão escolar e da reprovação dos alunos no ano de 1963. A reprovação seria um dos fatores de tanta evasão. Somando-se a isso, os profissionais qualificados ficavam muito mais concentrados nas grandes cidades. O problema se apresenta, no transcorrer do texto, muito mais grave. Não se podiam desprezar que o estado da educação tinha atingido esse nível de precariedade, devido a uma conjunção de fatores. Além dos já mencionados, famílias moravam distantes demais das escolas, outras não podiam abdicar da mão de obra dos próprios filhos para a subsistência. Assim, não os mandavam para a escola.

Apesar de o texto esmiuçar os problemas relacionados à educação, o jornalista apresentou como uma síntese do grave quadro, "Entre as várias causas relevantes, duas se destacam: formação defeituosa e inadequada (...) e falhas no sistema educacional”. Ao final da quarta página, o texto trouxe um subtítulo para continuar com a reportagem: “As duas Medidas". No trecho, usou-se o tempo da história, o plano enunciativo da história, já que se retoma a vida de um sujeito 3, no caso, a professora Maria Álvares Campos. Contouse, nessa parte do texto, que a moça só teria condição de estudar: “(...) a menos que fizesse o ginásio por conta do governo". "A menos que" atenua o quadro que ia se traçando para uma jovem, que tinha vontade de estudar. Essa atenuante se deu pelo uso da expressão, que é condicional.

Para levar ao leitor a idéia de veracidade, o recurso é apresentar dados estatísticos. Essa estratégia consubstancia em uma "ameaça à face" do governo, que deixou a situação da 
educação chegar onde chegou. Todo esse panorama traz um outro "vilão", o número bastante ativo de moças que se encaminhavam para o magistério, menos por opção do que por uma decisão dos pais.

No caso do sujeito 3, Maria Álvares Campos, esta que se esforçou para garantir sua vaga na escola normal. Prova disso foi que: “(...) freqüentou um cursinho preparatório para o exame (...) com aulas aos sábados, domingos e feriados e até mesmo no natal”. A conjunção aditiva "e" é expressiva para demonstrar o empenho da jovem não só aos finais de semana, como nos feriados.

Embora tenha havido o claro esforço da moça, ela entrou para as estatísticas das jovens que seguiam o decidido pelos pais. Para isso ser demonstrado, afirmou-se: “(...) aceita tudo". Além do verbo "aceitar", claramente expresso, intensifica-se a aceitação, por meio do pronome indefinido "tudo". No trecho, houve a mudança do tempo verbal, que passou ao presente, uma forma de reproduzir um fato atual. Contudo, na seqüência, outra mudança no tempo verbal ocorreu. Ao mencionar os sonhos da moça, prestes a se formar, optou-se pelo uso de verbos no futuro do presente: “(...) o salário (...) que o Estado lhe dará (...) corrigirá provas (...) dedicará mais duas horas à preparação da aula do dia seguinte”.

A página cinco inicia-se com o fim do sonho da moça, momento em que descobre a sofrida realidade da profissão, que tentou exercer a profissão, mas só colecionou desventuras, assim: “(...) lê um anúncio e começa a trabalhar como recepcionista de posto de gasolina (...)”. O texto segue mostrando uma crise sem precedentes, como mesmo recurso, vez por outra trazendo dados concretos e estatísticos.

$\mathrm{Na}$ parte final da reportagem, na sexta página, mencionou-se o curso universitário, como algo que na mesma proporção permitia uma mudança de status econômico e social, era quase inatingível para a grande maioria. Diante de tão grave quadro, o INEP aventava uma possibilidade de tentar cooptar mais homens para o cargo, estes teriam menos problemas para se deslocar para locais sem segurança, por exemplo.

Passaremos, então, para a reprodução do texto apresentado pela revista na seção "Reportagem: Tchecoslováquia: adeus à primavera" e a respectiva análise. 

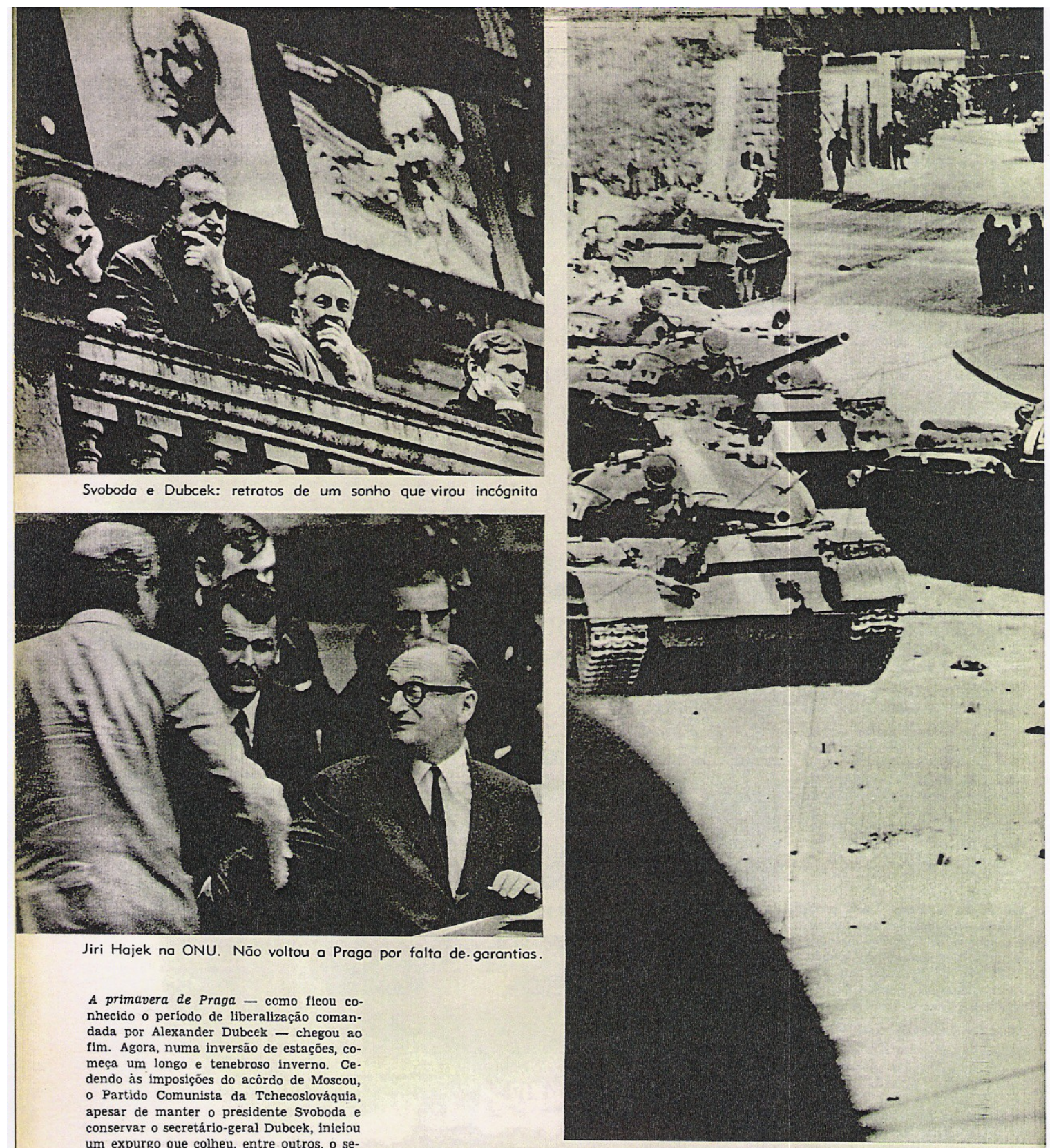

Jiri Hajek na ONU. Não voltou a Praga por falta de.garantias.

A primavera de Praga - como ficou conhecido o período de liberalização coman dada por Alexander Dubcek - chegou a fim. Agora, numa inversão de estaçōes, começa um longo e tenebroso inverno. Ce. dendo às imposiçōes do acôrdo de Moscou, - Partido Comunista da Tchecoslováquia, apesar de manter o presidente Svoboda conservar o secretário-geral Dubcek, iniciou um expurgo que colheu, entre outros, o secretário Cestmir Cisar e o ex-redator-chefe do Rude Bravo (jornal do $\mathrm{PC}$ ), Joset SpaPor não concordar em colaborar com polfoin necreta soviética, Joset Pavel com policla secreta soviética, Josel Pavel delxou o Mhisterio do interior. Este - e mais restabelecimento da cenłura à imprensa - o primeiro resultado da expitulaça posta pelo Kremlin à cúpula tchecoslovaca como condição para afrouxar a ccupação. Outras medidas virāo, esperando-se até a renúncia de Dubcek no encerramento, dia

Davis e Golias. Meninos de Bratislaya traduzem o repúdio de todo

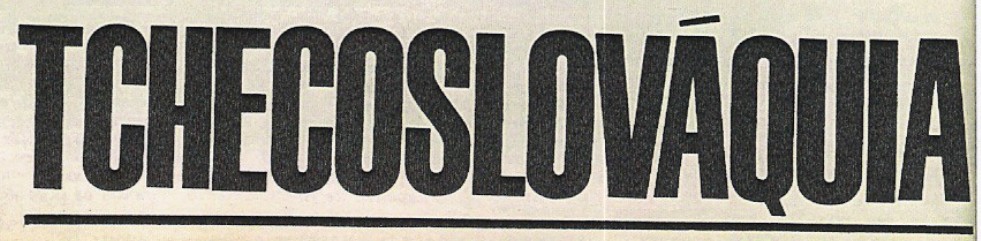




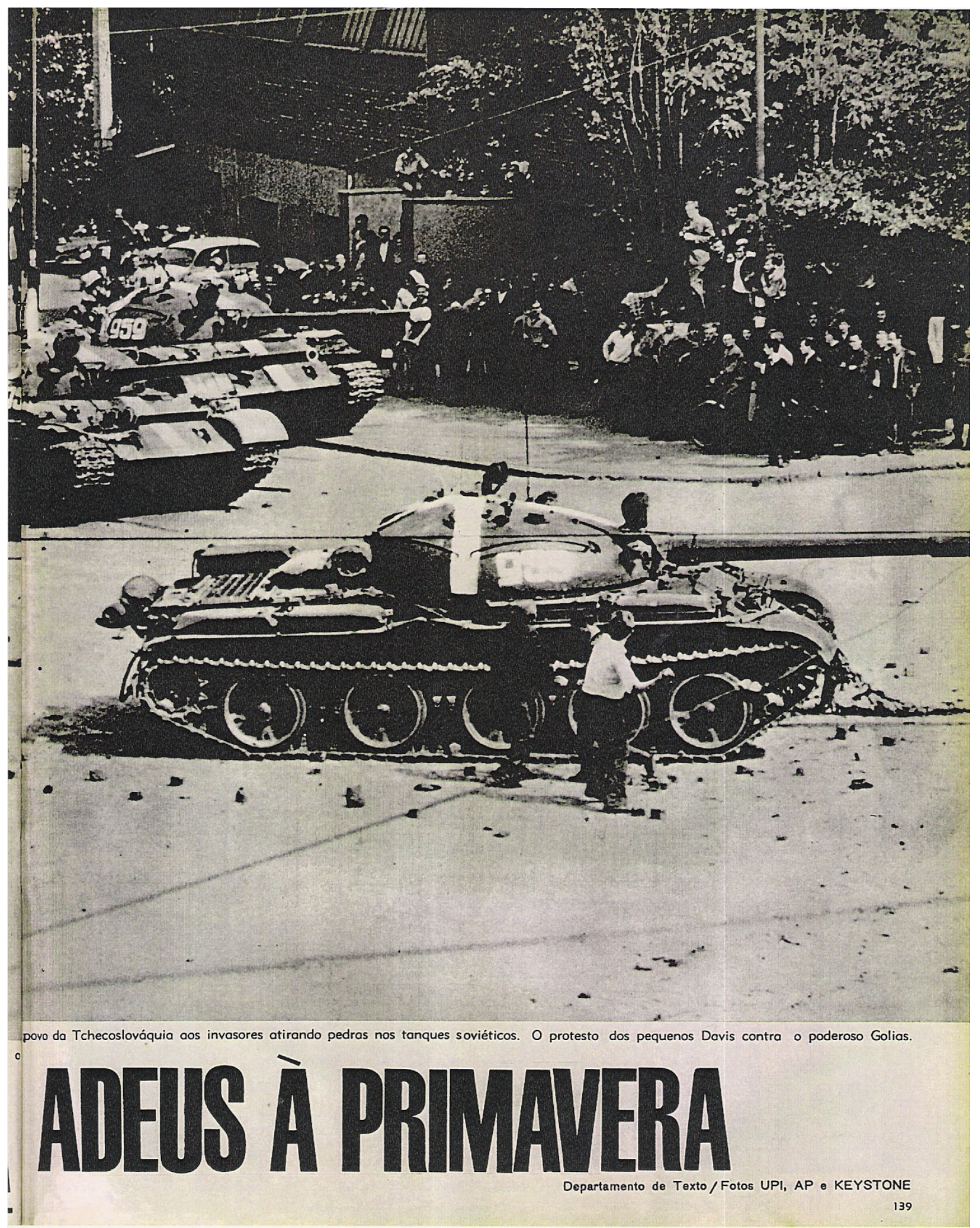



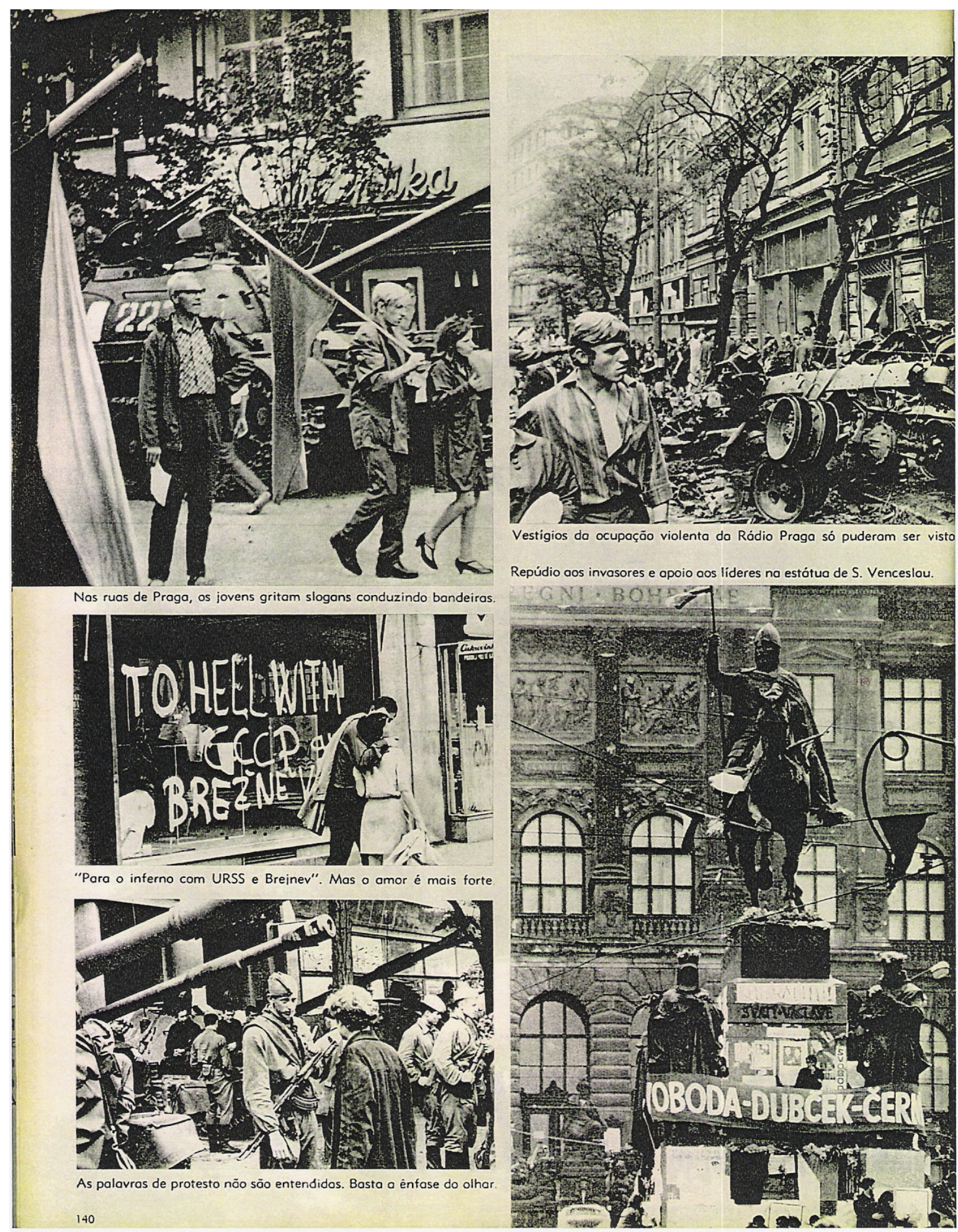


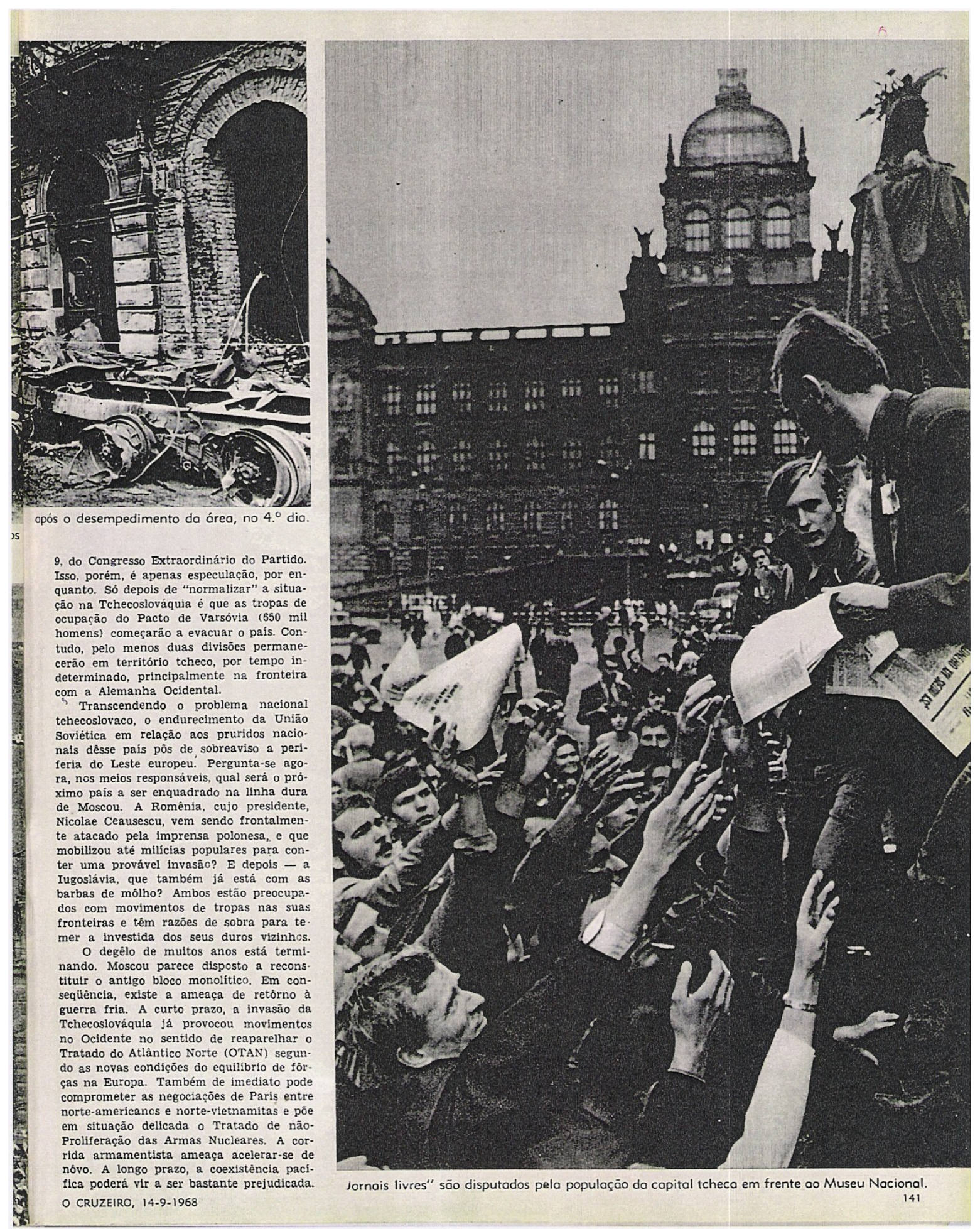


“Tchecoslováquia - adeus à Primavera”. A matéria não é assinada, mas que traz como informação acerca de sua produção: "Departamento de Texto/ Fotos UPI, AP e Keystone”, ocupa quatro páginas, com um total de nove fotografias. As duas primeiras páginas apresentam três fotos, sendo uma grande e central e apenas um parágrafo introdutório do texto verbal, aliás, um texto bastante curto, em proporção ao excessivo número de fotos. Especificamente às imagens do texto, nessa página inicial, a primeira foto é a chamada de síntese. Traz por crédito: "Svoboda e Dubcek: retratos de um sonho que virou incógnita". Tanto o ângulo da foto como os créditos são bastante emblemáticos. Trazem os líderes com ar de perplexidade, de dúvida, abaixo de retratos literais de dois homens. Os retratos não são muito claros, mas tanto podem ser dos próprios líderes, como de indivíduos que, de algum modo, podem ter contribuído para o sonho da "Primavera de Praga". A segunda é uma foto de registro, ou seja, apenas um subsídio de ancoragem para o texto. A foto de maior destaque traz o momento da invasão, dessa forma, pela sua função, é uma foto de flagrante, em que é possível observar um grande número de tanques militares russos pelas ruas de Praga.

Os créditos relativos a essa foto principal são extremamente sugestivos, nota-se a oposição que pauta o texto: "Davis e Golias", enfatizada pelo substantivo "meninos", para se referir a uma população que poderia ser comparada a de meninos, ao se levar em conta o oponente, as forças armadas soviéticas. A luta é tão desigual, que: “(...) o povo da Tchecoslováquia (...) atira pedras nos tanques soviéticos”. A carga expressiva continua nos créditos, ressaltando ainda mais uma vez a batalha desequilibrada: "O protesto dos pequenos Davis contra o poderoso Golias". O recurso dos adjetivos "pequenos" e "poderosos" antepostos aos substantivos próprios, nomes mitológicos que personificam, de um lado a coragem, apesar de pequenos, de pouca força e, de outro, a atrocidade, graças à força.

A terceira página da reportagem é composta apenas por fotos, num total de cinco. A primeira foto da página, em que se vêem os jovens empunhando bandeiras, é uma foto síntese, há uma voz coletiva, que tanto grita, como mostra, por atos, o que querem dizer, contra quem querem se levantar. Na foto em questão, não é difícil interpretar uma voz, que apesar de não ser explícita, faz-se ser "ouvida" e percebida pela imagem dos jovens com as 
bandeiras. A segunda foto, em que se observa um casal caminhando pela rua, diante de uma vitrine pichada, podemos julgá-la como foto de registro também, na medida em que unicamente ilustra o momento histórico.

$\mathrm{Na}$ terceira foto, o olhar de enfrentamento de um soldado soviético para um civil também parece enfática, mesmo que muda. Podemos ler a imagem como reprodução de uma manifestação de voz (silenciosa), mas que é igualmente oficial, já que partira de um representante do alto comando das forças armadas russas. As duas últimas fotos da terceira página também têm função de síntese. A quarta e a quinta foto mostram ações de ambos os lados. Na quarta fotografia, há a imagem da “(...) ocupação violenta da Rádio Praga”. E na quinta foto, vê-se a manifestação popular pró Svoboda e Dubcek. Na última foto, na página final da reportagem, vê-se a distribuição de jornal, há nos créditos a seguinte informação: “Jornais livres são disputados”, em mais uma crítica ao comunismo, já que o de fácil acesso eram apenas os jornais oficiais.

Quanto ao aspecto verbal do texto, também aqui é verificável a clara dualidade: de um lado, a fraca Tchecoslováquia e, de outro, a poderosa União Soviética. Na reportagem, embora não haja, de forma explícita, um discurso relatado, uma voz reproduzida literalmente, a oposição é clara entre os desígnios do poderoso Kremlin e, do lado oposto, quem ia contra ele, mesmo se estivessem inseridos num espaço tido como um bloco político. Isso, sem falar da óbvia oposição ocidental, em relação ao que era pregado pelo Partido Comunista Russo.

Independente da forma com que um texto mostra uma oposição de idéias, esse ato de expor perspectivas ideológicas distintas é próprio da linguagem, ao que se denomina heterogeneidade, uma característica de todo discurso. Essa heterogeneidade nada mais é do que assumir que um texto é carregado, atravessado pelo discurso do outro. Num discurso, o esperado é a presença de uma heterogeneidade constitutiva, ou seja, as vozes presentes. Não se trata apenas da voz do "eu”, pois este não existe sem o "outro". Uma explicação bastante clara quanto ao conceito de heterogeneidade constitutiva, termo, aliás, explorado por muitos autores, encontramos em Charaudeua \& Maingueneau (2004, p. 261):

Fala-se de "heterogeneidade constitutiva, quando o discurso é denominado pelo interdiscurso: o discurso não é somente um espaço no qual viria introduzir-se, do exterior, o discurso outro; ele 
se constitui através de um debate com a alteridade, independente de qualquer traço visível de citação, alusão etc. (...) em Bakhtin, a afirmação de um dialogismo generalizado; as palavras são sempre as palavras dos outros, o discurso é tecido dos discursos do outro. Em Pêcheux, a dupla referência à psicanálise e à concepção althusseriana da ideologia funda o primado do interdiscurso em relação a cada formação discursiva (...)

Enfim, como um discurso sempre se relaciona, de alguma maneira dialoga com outro ou outros, de uma mesma época ou mesmo de outra, o discurso, por si, é histórico. Já que o outro sempre se faz presente em um texto, isso prova que a linguagem é fundamentalmente heterogênea. O esperado de um texto é exatamente a apresentação ao menos de duas concepções distintas sobre um dado tema. Também não é incomum que um posicionamento se sobreponha ao outro, contando com um número maior de adeptos daquele específico ponto de vista, o que não elimina uma organização contrária a esses pensamentos sobre um mesmo assunto.

No caso específico do texto trabalhado, compreendemo-lo, predominantemente, como editorial. $\mathrm{O}$ artigo segue os parâmetros do gênero editorial, uma vez que o verificável é a presença do sujeito 1, a própria revista, em detrimento do sujeito 2, profissionais da equipe da reportagem. O pretendido apagamento de marcas subjetivas é verificado em alguns trechos. Por exemplo, em: "Pergunta-se", em que se confirma o esperado, o enunciador do texto jornalístico encontra-se refugiado à sombra de um órgão de imprensa e, mais ainda, de uma empresa que representa. Como já afirmado antes, esse pseudo distanciamento não assegura um posicionamento tão neutro ou objetivo como se tenta demonstrar.

Além de marcas peculiares ao gênero editorial, já mencionado, há marcas de relato histórico, além das marcas próprias do gênero comentário. Este é verificado até mesmo no momento em que algumas projeções são feitas, em que hipóteses são levantadas. A reportagem, sustentada mais nesses gêneros, traz algumas vozes que, unidas ou lutando em lados distintos podem ser resumidas da seguinte forma: agrupadas em vozes coletivas não oficiais, como uma maioria favorável ao enfrentamento da Tchecoslováquia e também vozes coletivas oficiais do partido comunista, cuja personificação na referência ao Kremlin mostrava-se não apenas discordar das ações advindas da Tchecoslováquia, como fortes o suficiente para coibir e ameaçar quem com "Ele” (Kremlin) não compactuasse. 
No que diz respeito à escolha do tempo, encontramos, como já visto nos demais, tanto o plano histórico da enunciação como o plano discursivo da enunciação. De certo modo, usados nas condições já apresentadas também. São elas, no plano histórico, o predomínio dos verbos no pretérito, como forma de recuperar o evento histórico, ao passo que no plano discursivo da enunciação, com a intenção de mostrar uma maneira de aproximação do sujeito enunciador, no momento de sua enunciação, o verbo no presente mostra muito bem isso.

O texto, logo no terceiro período do primeiro parágrafo, passou a usar o pretérito perfeito, justificado por referência ao já decorrido. Ainda ao final do primeiro parágrafo, o sujeito utilizou o futuro do pretérito, numa projeção do esperado pelo comando do Kremlin: “(...) renúncia de Dubcek no encerramento (...) do Congresso Extraordinário do Partido”. Entretanto, há que se fazer menção ao uso do futuro, como dito antes, quando das projeções e inferências postas. Se já iniciamos um esboço sobre as vozes encontradas no curto texto, passamos a nos deter mais nessa polifonia.

Comecemos pelo título: “Tchecoslováquia - Adeus à Primavera”, aliás que se encontra diferente no sumário, em que se lê: Tchecoslováquia invadida", verifica-se uma voz coletiva, advinda tanto da população que via com bons olhos o enfrentamento ao Kremlin, proporcionado por Svoboda, presidente da Tchecoslováquia e Dubcek, secretário-geral, como a voz dos mesmos. Era uma voz oficial, mas não em nome do Partido Comunista, de forma geral, mas de quem representava o poder na Tchecoslováquia. Pelo texto, depreendese ter havido entre Svoboda e Dubcek um afinamento. Os dois são mostrados sob a perspectiva de políticos, cujas vozes, mesmo não sendo recuperáveis pelo contexto, mostraram tão afinadas, a ponto de fazerem um coro bastante alto, só sendo caladas pelo som retumbante dos tanques soviéticos. No decorrer da reportagem, detectamos uma voz esperada, que é a da revista, entretanto, não encontramos a reprodução literal de uma fala de um sujeito 3, algum “personagem” mencionado no artigo.

Na sequiência do trecho, vemos uma voz oficial, mas também não oficial do Kremlin, oficial de outro país, a Romênia, que a exemplo da Tchecoslováquia, buscava um certa soberania, que talvez só fosse possível como consequiência de algum crescimento econômico, o que até então não estava acontecendo. 
Diante de um atraso tamanho e pouca liberdade de atuação, Ceausescu, presidente da Romênia, apesar de atacado pela imprensa polonesa, movimentou-se, a fim de mostrar a intenção em não aceitar uma iminente e possível invasão. O que poderia ocorrer, graças a atos e palavras proferidas pelo presidente e que atingiam a imagem do país e do partido comunista.

Enfim, as vozes, nesse texto, são muito menos explicitadas, se comparadas a alguns outros textos já estudados. Nossa hipótese é de que a revista apresenta, por intermédio de sua própria voz, um ethos de atual, informativa, por outro lado, apresenta-se ou como limitada a não explorar mais aprofundadamente o tema, em virtude da distância ou mesmo por uma opção editorial e/ou ideológica. Essa hipótese pode ser reforçada, conforme já dito, pelo excessivo número de imagens, se comparado com o reduzido espaço dado ao texto escrito. É inegável que as imagens carregam também em si uma carga ideológica.

Apesar da pretensa imparcialidade, pela opção quanto à estrutura do texto, quer em seu plano de expressão verbal, quer em seu plano de expressão não-verbal, mostra-se seguindo uma tendência do Ocidente, no que se refere a uma crítica ao regime soviético. Este mais uma vez nos foi mostrado como nefasto, como uma ameaça à tão pretendida paz mundial.

Quanto a outros recursos, comecemos pelo início do texto: “A Primavera de Praga (...) chegou ao fim”, aproveitou-se do campo semântico das estações do ano para mencionar, conforme o esperado por uma estação, no caso a primavera, uma metáfora para designar o importante evento histórico da Tchecoslováquia, que chegara ao fim. Para seguir nesse campo semântico, é verificado em "Agora numa inversão de estações, começa um longo e tenebroso inverno”. Se conotativamente primavera é referida como um momento de boas expectativas, inverno, também em sentido figurado, pode representar um período sombrio, de pouca esperança, o que, enfim, a nova realidade da Tchecoslováquia após ter se insurgido contra o Kremlin.

Outra significativa utilização lingüística diz respeito ao uso da voz passiva, em vários trechos: “(...) ficou conhecido (...) (o período); (...) capitulação imposta pelo Kremlin (...); (...) Ceaucescu vem sendo frontalmente atacado pela imprensa polonesa (...); O degêlo (...) está terminando". No primeiro e no último caso, os sujeitos das ações estão omitidos. No primeiro exemplo, nenhum dado parece relevante, o importante era ter atingido o grau de um movimento vultoso, de significativa projeção, para o que a revista chamou de "degêlo", 
uma forma metafórica de mostrar o isolamento a que estava restrito o bloco soviético. No segundo e no terceiro casos, a passiva é mais contundente para expor ações sofridas pelo sujeito, a "capitulação" e o presidente Ceausescu; além de apresentar os sujeitos agentes: o Kremlin e a imprensa polonesa, respectivamente.

Outros recursos lingüísticos podem ser notados. A expressão "linha dura", antecedida, enfaticamente pelo vocábulo "enquadramento", um substantivo abstrato, muito utilizado no campo semântico concernente a ações militares, que, próximo da mencionada expressão "linha dura", reforçam a crueza do regime.

No fragmento, “Isso (...) é apenas especulação, por enquanto”, o uso de "isso", anafórico, diz respeito à possível renúncia do político citado na revista, por ocasião do congresso extraordinário do partido comunista. Como essa era uma hipótese forte, dados os acontecimentos, a locução temporal "por enquanto" parece apenas um recurso retórico atenuante.

Na explicação do rumo dos futuros acontecimentos, em consequiência do vivido naquele maio de 1968, a matéria trouxe a informação de que Praga só seria desocupada, após julgarem (o Kremlin) estar a situação "normalizada". Ao falar nessa normalidade, a reportagem lançou mão do uso das aspas, que não deixa de ser uma marca, mesmo que implícita, ideológica. Afinal, uma questão nas estrelinhas do trecho ficava por conta de saber o que era normal, aos olhos do alto comando do Partido Comunista. A normalidade, pelo contexto, talvez fosse uma simulação, a fim de convencer a população de levar a vida como antes. A maneira de apresentar uma oposição à chamada "normalidade" é verificada com o uso da conjunção coordenativa "contudo", para mencionar que a ocupação continuaria por tempo indeterminado.

Reconhecemos, num dado trecho do texto, o que entendemos como uma pergunta retórica, a revista apresenta a dúvida e, ela mesma, responde. A mencionada passagem se deu frente à hipótese de outra provável invasão. No fragmento, referiu-se, como as repúblicas que estariam "na mira” do Kremlin, à Romênia e à Iugoslávia. Merecem atenção certos trechos: "barbas de molho", utiliza-se a bastante explorada expressão, com a finalidade de se reportar ao fato de as mencionadas repúblicas terem, em suas fronteiras, tropas armadas. Em decorrência de nossas informações anteriores, relativas a toda essa situação, sabíamos dos conchavos dos presidentes das duas repúblicas, que se preparavam 
para um iminente ataque soviético. Contudo, esses dados não foram abordados nesse texto da Cruzeiro.

O penúltimo parágrafo do texto traz a afirmação de que as severas medidas tomadas a partir da Rússia, no sentido de conter o que poderia vir a se propagar nos demais países do bloco socialista, fez-se entender (voz oficial) o que os militares soviéticos fariam para não deixar se espalhar uma onda de instabilidade.

Muitas críticas são verificadas no decorrer do texto, mesmo que subliminarmente, uma maneira de pôr em causa não só as medidas pontuais da URSS, mas o regime soviético como um todo. Um dos fragmentos que essa oposição crítica ocidental pode ser vista é: “(...) na qual será o próximo país a ser enquadrado na linha dura de Moscou”. Pelo trecho, não se duvidavam de duas coisas: de que os descontentamentos com o regime iriam continuar e, quiçá, manifestações de maior ou menor monta e, por outro lado, o recrudescimento do regime socialista, verificado no trecho logo acima reproduzido, por meio da tão explorada expressão, bastante pertinente em contextos de governos totalitários. 


\section{CONCLUSÃO}

Ao longo do presente trabalho, principalmente nas análises, buscamos evidenciar a relação do homem com a sociedade. Nosso enfoque recaiu sobre uma pequena parcela da interação do homem com o meio pela linguagem. Trata-se de uma amostra dessa interação, por partirmos de duas publicações específicas, revistas semanais brasileiras e portuguesas.

Essa busca, o de analisar os aspectos concernentes à relação do homem com a sociedade por meio da linguagem, levou-nos ao estabelecimento de outros objetivos, os específicos, que nos possibilitaram compreender e explicar nosso objeto de análise.

Entretanto, antes disso, alguns elementos foram imprescindíveis. Inicialmente, fezse necessário fazer um panorama sociopolítico da Era Salazar, em Portugal e da Ditadura Militar, no Brasil. Na abordagem não exaustiva da temática, propusemo-nos a pontuar os elementos mais significativos que chamam a atenção do leitor na análise das revistas. A seguir, dada a natureza da temática, voltamo-nos para a conceituação de ideologia e, posteriormente, abordamos a mídia impressa.

Como para este trabalho utilizamos modelos teóricos da $\mathrm{AD}$ de linha francesa, a próxima etapa consistiu no enfoque das propostas sócio-interacionistas que, não sem propósito, tiveram seu nascedouro na década de 60 .

Assim, após pensarmos essas etapas basilares, chegamos à exploração do discurso ideológico que permeia as duas revistas, que, provavelmente em virtude das imposições da censura devem ou podem ser orientados de alguma maneira. Isso permitiu que se visualizasse como se dá a construção da argumentação, a qual é elaborada, objetivando atingir determinado público-alvo.

Ao levantarmos marcas lingüísticas a partir dos discursos presentes nos textos analisados, acreditamos ter revelado determinadas posturas ideológicas, o que era nosso primeiro objetivo. De fato, em uma como em outra publicação essas marcas não apresentavam uma regularidade de posicionamento. Aliás, mesmo que às vezes sutilmente, detectamos posturas ideológicas diferentes num mesmo número das revistas, pela própria condução de certo assunto, assim como pela pouca ou grande ênfase dada ao fato. A verificação da maior ou menor profundidade concedida para determinados temas configurava-se em nosso segundo objetivo, o que também acreditamos ter atingido. 
A maneira de construir um texto, sobretudo em um órgão de imprensa, mesmo em nome da imparcialidade, não deixa de estar a serviço de uma ideologia ou de interesses, com objetivos variados.

Pudemos, por meio da materialidade lingüística, verificar o trabalho argumentativo dos textos, com objetivo claro de convencer o público-alvo, bem como qualquer outro leitor a seguir por determinada trilha, a um raciocínio, a fim de chegar a uma dada conclusão. A conclusão exposta pela própria revista apresenta, normalmente, o fato noticiado sob dois aspectos. Há, de forma geral, uma organização textual que orienta o leitor a perceber certa dualidade. Essa dualidade configura-se quase que num maniqueísmo, em que se depreende, pelo exposto, o que faz parte do que seria tido por bem e o que seria tido por mal.

Obviamente esse posicionamento da dita verdade, do que é bom e do que é ruim, de acordo com a mídia, como já afirmado, nada mais é do que uma suposta idéia de verdade, do bem e do mal. Cabe à mídia se colocar como um órgão da imprensa livre, imparcial e não manipuladora; ao leitor cabe o papel de crer ou não, concordar com ela ou não. Como obtivemos resultados a partir desse encaminhamento dado pelas marcas lingüísticas, fiamonos também ter chegado a bom termo nesse objetivo.

O último objetivo específico, qual seja: a identificação da polifonia presente nos textos, a fim de depreender o ethos das revistas e de seus colaboradores, foi igualmente atingido, na medida em que, por aspectos lingüísticos, detectamos uma confluência de várias vozes na composição dos textos. A nosso ver, essa polifonia contribuiu para que o leitor, mesmo que menos crítico, construísse um ethos da revista, diferente da visão do analista do discurso, para quem tanto a polifonia como as marcas lingüísticas propiciam não apenas perceber o ethos da revista, como também o ethos do sujeito 2, dos colaboradores da revista e, vez por outra, o ethos do sujeito 3, pessoas envolvidas no tema explorado no texto jornalístico. Bem verdade, que o ethos do órgão de imprensa e o ethos de seus colaboradores, às vezes, mostram-se em perfeita sintonia, independente de ter havido, por parte do sujeito 2 uma intencional ou não marca de pretensa subjetividade.

Para que nosso estudo seguisse um percurso histórico, bem como orientado pela Lingüística, sem deixar de lado marcas coletivas de uma sociedade, até mesmo levando em conta aspectos comportamentais, a Análise do Discurso de linha francesa, como já afirmamos, levou-nos a muitas respostas. Ela nos indicou categorias de análise que nos 
auxiliaram na compreensão de um ano que ficou marcado na história recente da humanidade.

Em nossa análise, detivemo-nos mais na questão do dialogismo, da polifonia, ou seja, afinamos nosso olhar para as vozes presentes nos textos. Recuperando idéias de Bakhtin (2004), no que se refere ao caráter dialógico da palavra e polifônico do discurso, buscamos essas vozes presentes em textos variados no gênero do discurso jornalístico. Essa busca foi consolidada pela materialidade lingüística, bem como pela diagramação do texto, no seu plano de expressão e no plano de conteúdo. Procuramos levar em conta, não como um critério de análise, mas como propulsor de algumas respostas, os gêneros discursivos presentes nos textos estudados.

Por meio dessas categorias, ratificando o dito antes, esses encaminhamentos possibilitaram-nos depreender com mais clareza a ideologia das duas revistas de ampla circulação, mesmo num momento em que a imprensa, de forma geral, estava em estado de atenção. A partir dos resultados dessas análises dos textos, pudemos confirmar muito do poder da imprensa. Indiscutivelmente, esse importante meio de comunicação, que é a mídia impressa, foi capaz de mostrar e também de omitir o que se viveu no instigante ano de 1968.

O fácil acesso a distintos meios de comunicação, bem como seu inegável poder senão de manipulação, ao menos de atração do grande público talvez seja o motivo de tantos pesquisadores terem a imprensa por objeto de estudo, o que também nos motivou. Interessou-nos entender os encaminhamentos de estruturação textual, bem como verificar os recursos relativos ao plano de expressão com que contou uma específica mídia impressa brasileira e outra portuguesa. Iniciamos nosso trabalho buscando verificar as estratégias argumentativas e ideológicas de revistas que circulavam normalmente em momentos de pouca abertura política. Independente da linha ideológica de uma revista ou jornal, a abordagem de temas, a filtragem das informações, tendo em vista não só um determinado regime de governo, mas também um certo tipo de público-alvo podem ser detectados por marcas de linguagem verificáveis tanto pelo plano de conteúdo como pelo plano de expressão. A polifonia presente nos textos assegurou e até mesmo confirmou muitas de nossas prévias hipóteses de como certos assuntos foram abordados. 
O discurso da imprensa procura refletir a sociedade de seu tempo, independentemente do aspecto relativo à manipulação da informação, objetivando mostrar o que chama de realidade. Acerca disso, Grillo (2006, p. 48) afirma:

Do ponto de vista pragmático, a imprensa contemporânea brasileira de referência se funda sobre a noção de representação do real e mobiliza formas capazes de evidenciar a transparência da imprensa em relação ao real por ela mostrado (...) "O real é o que eu mostro".

Não cremos que esse posicionamento se deva apenas à imprensa brasileira. Todo veículo de comunicação, assim como instituições e mesmo pessoas, investem num ethos que lhe confira não só credibilidade, mas que a confiança pretendida seja conseguida pelo tom de intimidade, de compreensão, facilmente alcançado em diferentes gêneros textuais.

Os recursos de que a mídia dispõe para comunicar algo podem ser extremamente eficazes, em muitas situações, em função de trabalhar com linguagem variada, por meio de textos verbais e não verbais. Entretanto, há distinção entre um veículo de informação e outro, por exemplo no que diz respeito às diferenças verificáveis da mídia imprensa para a televisiva ou radiofônica. Em relação a isso, Grillo (2006, p. 50) esclarece:

O discurso da imprensa está ligado a uma função social mais ampla que é o discurso midiático de informação e se difere dos outros discursos midiáticos, rádio e televisão, pelas características de seu suporte material. Enquanto os diversos gêneros da imprensa podem variar quanto às finalidades, à identidade dos parceiros, aos aspectos enunciativos, a parcela do real tratado etc., o dispositivo material é um aspecto que atinge a imprensa como um todo.

No tocante propriamente ao corpus de nosso trabalho, levando em conta os diversos números consultados da revista Flama, a linha editorial se mostrou oscilante, mas com um fio condutor mais exposto, em especial no que diz respeito a um posicionamento não exatamente laico e tendo a família como a instituição por excelência. Quanto à O Cruzeiro, de épocas e mesmo de décadas distintas, não podemos afirmar também que existe uma linha editorial clara e coerente, que tenha se mostrado explícita ideologicamente.

Para ilustrar esse aspecto de pouca ou de difícil coerência percebida, no que se refere ao editorial das revistas, na Flama encontramos reportagens sobre um festival de 
vestidos feitos com o tecido chita e artigos sobre os conflitos nas colônias ultramarinas. Essa opção por temas tão díspares foi por nós detectada também em O Cruzeiro, com artigo sobre a vida pessoal do noivo da miss universo e, por outro lado, uma reportagem sobre a invasão, pelo DOPS, na Universidade de Brasília.

Dessa maneira, apesar das várias vozes invocadas na composição dos textos trabalhados, não nos parece apropriado delimitar objetivamente um ethos específico para a revista $\mathrm{O}$ Cruzeiro e um para a Flama, mesmo tendo as duas publicações tantas características em comum. $\mathrm{O}$ curioso não se dá pela falta de um direcionamento editorial, no que concerne a números de ambas publicações em diferentes anos ou décadas, mas essa não coesão ideológica é passível de ser verificada num ano específico ou até num mesmo número, pela distinta abordagem e ênfase dada a certos assuntos.

Quanto a características comuns das revistas analisadas, estas vão da longevidade de ambas, a recordes de público leitor, assinante ou não, a preferência por mulheres nas capas, em especial do meio artístico, entre outras semelhanças. Bem verdade que muitas dessas marcas são próprias desse gênero de revista de variedades.

$\mathrm{O}$ aspecto mais artístico, sem dúvida, encontra-se na qualidade e na quantidade de fotos da revista $\mathrm{O}$ Cruzeiro. A qualidade não se restringe à tipografia, mas à qualidade técnica desse trabalho. Tanto como já apresentado antes, que a partir de meados da década de 40 a quase personificação da revista se deu pela união de dois reconhecidos profissionais. A dupla Davi Nasser, repórter, e Jean Manzon, este um fotógrafo com experiência anterior muito importante, por ter trabalhado na conceituadíssima revista francesa Paris Match tornou-se nome - marca de O Cruzeiro.

Também de inegável qualidade eram os nomes dos colaboradores, nesse quesito, tanto de o Cruzeiro, como da Flama, já que alguns grandes repórteres, fotógrafos e escritores fizeram parte como profissionais contratados ou como colaboradores esporádicos.

Uma leitura interpretativa, como a feita por nós, não pode desconsiderar fatores imprescindíveis, a fim de chegar a resultados e a conclusões que não sejam questionáveis. Assim, temos a convicção de que ler $\mathrm{O}$ Cruzeiro de quarenta anos atrás obviamente não pode reproduzir os mesmos encaminhamentos de um leitor da época, mesmo porque temos muitas das respostas e desfechos imaginados apenas naquele momento. Mais cuidado ainda 
tentamos ter ao analisar a publicação portuguesa Flama, tendo sempre em vista que não só não a líamos com os olhos de 1968, mas especialmente não o fizemos como leitores nativos.

$\mathrm{Na}$ esperança de termos procedido ao estudo com os cuidados acima apresentados, passamos a um breve processo de refazer o nosso percurso. O caminho percorrido, voltando quarenta anos no tempo, permitiu-nos uma instigante viagem para um ano tão emblemático e que tem sido alvo de manifestações e lembranças em muitos países. Exemplo disso foram os vários eventos relembrando especialmente o mês de maio de 1968. Concluímos, a partir de todo nosso processo de leitura e de reconstrução de um ano, que, de algum modo, o leitor que buscar construir 1968 por meio dessas publicações provavelmente conseguirá (re) compor parte do contexto, aquilo que foi menos filtrado ou pelas ditaduras em curso ou pela própria opção editorial da revista, guiada segundo uma ideologia ou interesses pontuais, tendo em vista um momento ou outro.

Acreditamos que por meio desses mesmos textos outras importantes leituras e análises possam ser feitas. Muitas das questões políticas tratadas podem ser mais detidamente abordadas, partindo de outros enfoques teóricos ou até mesmo com as teorias lingüísticas presentes neste trabalho. $\mathrm{O}$ ano de 68 pode ser muito mais explorado sob diversos aspectos, históricos, comportamentais e mesmo lingüísticos. Esperamos ter contribuído, de alguma maneira, para mais uma leitura do período. 


\section{REFERÊNCIAS BIBLIOGRÁFICAS}

ALTHUSSER, Louis. Aparelhos Ideológicos de Estado: nota sobre os aparelhos ideológicos de Estado (AIE). 2 ed. Trad. Walter José Evangelista e Maria Laura Viveiros de Castro. Rio de Janeiro: Edições Graal, 1985.

AMOUSSY, Ruth (Org.). Imagens de si no discurso: a construção do ethos. São Paulo: Contexto, 2008.

ANDRÉ, Maria Eliza Dalmazo Afonso de. Estudo de caso em Pesquisa e Avaliação Educacional. Brasília: Líber Livro Editora, 2005.

ARRUDA, José Jobson; FONSECA, Luís Adão (Org.) Brasil - Portugal: História, agenda para o milênio. Bauru: EDUSC; São Paulo: FAPESP; Portugal: ICCTI, 2001.

; PILETTI, Nelson. Toda a História- História Geral e História do Brasil. 4 ed. São Paulo: Editora Ática, 1996.

AUTHIER-REVUZ, Jacqueline. Heterogeneidade(s) Enunciativa(s). Trad. Celene Cruz e J. Wanderley Geraldi. In: Cadernos de Estudos Lingüísticos 19. Campinas: UNICAMP/IEL.

AZEREDO, José Carlos (Org.). Letras e Comunicação: uma parceria no ensino de língua portuguesa. Rio de Janeiro: Vozes, 2001.

BATISTA, Angelina. Imaginário e redação: leituras possíveis. São Paulo: Zouk, 2002.

BAKHTIN, M.; Volochínov, V. N. Marxismo e filosofia da linguagem. 11. ed. Trad. Michel Lahud e Yara Frateschi Vieira. São Paulo: Hucitec, 2004 (Original russo, 1929).

. Estética da Criação Verbal. 4. ed. Trad. Paulo Bezerra. São Paulo: Martins Fontes, 2003 (Original russo, 1953).

. Problemas da Poética de Dostoievski. Trad. Paulo Bezerra. Rio de Janeiro: Forense Universitária, 1981.

BARBOSA, Marialva.O Cruzeiro: uma revista síntese de uma época da história da imprensa brasileira. Rio de Janeiro, 2006. Dissertação (Mestrado) - Universidade Federal Fluminense. 
BARROS, Kazue Saito Monteiro de (Org.). Produção Textual-Interação, processamento, Variação. Natal: Editora da UFRN, 1999.

BENVENISTE, E. Problemas de lingüística geral I. 4 ed. Trad. Maria da Glória Novak e Maria Luisa Néri. Campinas: Pontes, 1995.

BRAIT, Beth (Org.). Estudos enunciativos no Brasil: história e perspectivas. Campinas: Pontes; São Paulo: FAPESP, 2001.

BRANDÃO, Helena H. N. Introdução à análise do discurso. Campinas: Editora da UNICAMP, 1991.

. Gêneros do discurso na escola. São Paulo: Cortez Editora, 2000, v. 5.

. Análise do Discurso: Um Itinerário Histórico. In PEREIRA, Helena, Bonito

Couto; ATIK, Maria Luiza Guarnieri (Org.) Língua, Literatura e Cultura em Diálogo. São Paulo: Editora Mackenzie, 2003.

. Gêneros do Discurso, Estilo e Implicações Didáticas. 52 Seminário do GEL, IELUNICAMP, 29-31 jul. 2004.

BRANDÃO, Sílvia F. Mota, Maria Antónia (Org.). Análise contrastiva de variedades do Português. Rio de Janeiro: In-Fólio, 2003.

BRASÃO, Inês. As Revistas de Sociedade em Portugal. In: Estudos de Sociologia da Leitura em Portugal no século XX. Lisboa: Edição Fundação Calouste GulbenkianFundação para a Ciência e a Tecnologia, 2006.

CAMPBELL, JOSEPH. O Poder do Mito. Trad. Carlos Felipe Moisés. São Paulo: Palas Athena, 1990.

. As Máscaras de Deus. Trad. Carmen Fischer. São Paulo: Palas Athena, 1992.

Isto és tu-Redimensionando a metáfora religiosa. Trad. Bini. São Paulo; Landy

Editora, 2002.

CARVALHO, José Murilo. A Formação das Almas: o Imaginário da República do Brasil. São Paulo: Companhia das Letras, 1990.

CARVALHO, Maria Teresa Nastri. Revisitando a produção de textos narrativos. São Paulo, 1998. Dissertação (Mestrado) - Pontifícia Universidade Católica de São Paulo.

CASAGRANDE, Nancy dos Santos. A Implantação da Língua Portuguesa no Brasil do Século XVI: Um Percurso Historiográfico. São Paulo, 2001. Tese (Doutorado) - Pontifícia Universidade Católica de São Paulo. 
. Os Bastidores do Discurso Político Sindical. São Paulo, 1996. Dissertação (Mestrado) - Pontifícia Universidade Católica de São Paulo.

CASTELLO BRANCO, Carlos. Os militares no poder. Rio de Janeiro: Nova Fronteira, 1977, v. 1-3.

CHAUÍ, Marilena. O que é Ideologia. São Paulo: Editora Brasiliense, 1980.

CHARAUDEAU, Patrick; MAINGUENEAU, Dominique. Linguagem e Discurso- modos de organização. Trad. Ângela S. M. Corrêa. São Paulo: Contexto, 2008.

Discurso das Mídias. Tradução Ângela S. M. Corrêa. São Paulo: Contexto, 2006.

. Dicionário de Análise do Discurso. Trad. Fabiana Kombu. São Paulo: Contexto,

2004.

CHARTIER, Roger. A História Cultural, entre práticas e representações. Lisboa: Difiel, 1988.

CLUBE dos Jornalistas. Disponível em: $\{$ www.clubedosjornalistas.pt $\$$. Acesso em: $11 / 10 / 2007$

COURTINE, Jean-Jacques. Metamorfoses do discurso político: as derivas da fala pública. Trad. Nilton Milanez e Carlos Piovezani Filho. São Carlos: Claraluz, 2006. . Analyse du discours politique. LANGAGES 62. Paris: Larousse, 1981.

CURI, Samir Meserani. O intertexto Escolar; sobre leitura, aula e redação. São Paulo: Cortez, 1995.

CURTO, Diogo Ramada. (Dir.). Estudos de Sociologia da Leitura em Portugal no século XX. Lisboa: Edição Fundação Calouste Gulbenkian- Fundação para a Ciência e a Tecnologia, 2006.

DIAS, Alexandre \& ALMEIDA, Rogério (Org.). Metamorfopsia da Educação. Hiatos de uma aprendizagem real. São Paulo: Zouk, 2002.

DIONÍSIO, Ângela P.; MACHADO, Anna R.; BEZERRA, Maria Auxiliadora. (Org.) Gêneros textuais \& ensino. Rio de Janeiro: Lucerna, 2003.

DISCINI, Norma. A Comunicação nos textos. São Paulo: Contexto, 2007.

DURAND, Gilbert. O Imaginário - Ensaios acerca das Ciências e da Filosofia da imagem. 2 ed. Trad. René Eve Levié. Rio de Janeiro: Difel, 2001. 
As Estruturas Antropológicas do Imaginário. 2 ed. Trad. Hélder Godinho. São Paulo: Martins Fontes, 2001.

. Imagens e Reflexos do Imaginário Português. Trad. Cristina Poença, Lima de Freitas, Jeannine Quintin e Ana Isabel Buescu. Lisboa, Hugin editores, 2000.

A Imaginação Simbólica. 6 ed. Trad. Carlos Aboim de Brito. Lisboa: Edições 70 Ltda, 1993.

ELGIN, Suzette Haden. Que é lingüística? 2 ed. Rio de Janeiro: Zahar Editora, 1981.

FAUSTO, Boris. História do Brasil. 8 ed. São Paulo: Editora da Universidade de São Paulo; Fundação para o Desenvolvimento da Educação, 2000.

FERNANDES, Cleudemar Alves. Interação social e formação discursiva No movimento de luta pela terra.São Paulo, 2001. Tese (Doutorado em Lingüística) - FFLCH/USP.

. O Coronel e o Lobisomem: Uma Abordagem Sócio-Interacional. São Paulo: Annablume, 1999.

FERREIRA, Aurélio Buarque de Hollanda. Pequeno Dicionário Brasileiro da Língua Portuguesa. 11 ed. Rio de Janeiro: Gamma, s/d.

FOUCAULT, M. A Ordem do Discurso. Trad. Laura Fraga de Almeida Sampaio. Lisboa: Relógio D’ Água, 1997.

. Sobre a história da sexualidade. In Microfísica do Poder. (Organização e tradução de Roberto Machado), Rio de Janeiro, Graal, 1979.

. Arqueologia do saber. Trad. L.F. Baeta Neves. Petrópolis: Editora Vozes, 1971.

GADET, Françoise; HAK, Tony. Por Uma Análise Automática do Discurso: Uma Introdução à Obra de Michel Pêcheux. Trad. Bethânia S. Mariani. Campinas: Editora da UNICAMP, 1997.

GOFFMAN, Erving. A Apresentação do Eu na Vida de Todos os Dias. Tradução Miguel Serras Pereira. Lisboa, Relógio D’ Água, 1993.

. Ritual de la Interación. Buenos Aires: Tiempo Contemporáneo, 1974.

GRILlO, Sheila Vieira de Camargo. A produção do real em gêneros do jornal impresso. São Paulo: Associação Editorial Humanitas, 2004. 
HERNANDES, Nilton. A Mídia e seus truques. São Paulo: Contexto, 2006.

HOLANDA, Sérgio Buarque. Raízes do Brasil. 26 ed. São Paulo; Companhia das Letras, 1995.

HOUAISS, Antônio. Dicionário Houaiss de Língua Portuguesa. Rio de Janeiro: Objetiva, 2001.

JUNG, Carl G. O Homem e seus Símbolos. Trad. Maria Lúcia Pinho. Rio de Janeiro: Editora Nova Fronteira, 1977.

KOCH, I. G. V. A inter-ação pela Linguagem. São Paulo: Contexto, 2000.

; BARROS, Kazue Saito Monteiro de. (Org.) Tópicos em Lingüística de Texto e Análise da Conversação. . Natal: Editora da UFRN, 1997.

LEITE, Marli Quadros. Variação Lingüística: Dialetos, Registros e Norma Lingüística. In: SILVA, Luiz A. (Org.) A Língua que Falamos - Português: história, variação e discurso. São Paulo: Globo, 2005.

LEITE, Renato Lopes. Noções de liberdade em alguns jornais anarquistas portugueses do início do século XX. In: SZESZ, Christiane Marques et alii (Org.) Portugal-Brasil no século XX: sociedade, cultura e ideologia. Bauru: EDUSC, 2003.

LIMA-FERNANDEZ, Maria Cecília. A Dimensão social das Palavras. In: SILVA, Luiz A. (Org.) A Língua que Falamos- Português: história, variação e discurso. São Paulo: Globo, 2005.

LONARDONI, Marines. Cartas de Leitores: um estudo do discurso e da construção argumentativa das cartas de leitores em revistas. Araraquara, 2004. Tese (Doutorado em Lingüística. e Língua Portuguesa) - Universidade Estadual Júlio de Mesquita Filho/UNESP.

MAGALHÃES, Ana Maria; ALÇADA, Isabel. 25 de Abril. Lisboa: Assembléia da República - Divisão de Edições, 2004.

MAINGUENEAU, Dominique. Análise de textos de comunicação. 3 ed. Trad. Cecília P. Souza e Silva e Décio. São Paulo: Cortez, 2004.

1989.

Novas tendências em análise do discurso. 2 ed. Campinas: Pontes/UNICAMP,

MARTINS FILHO, Eduardo Lopes. Manual de Redação e Estilo de o Estado de São Paulo. São Paulo; O Estado de São Paulo, 1997.

MATTOSO, José. História de Portugal: O Estado Novo. Lisboa: Estampa, 1994, v. 7. 
MEMÓRIA Viva. Disponível em: 〈LWWw.memoriaviva.com.brخ. Acesso em: 30 nov. 2007.

MELO, Daniel. A Leitura Pública no Portugal Contemporâneo (1926 - 1987). Lisboa: Imprensa de Ciências Sociais do Instituto de Ciências Sociais da Universidade de Lisboa, 2004.

MORAES, Letícia Nunes. Cartas ao Editor: leituras da revista Realidade (1966-1968). São Paulo: Alameda, 2007.

MORAIS, Fernando. Chato: o rei do Brasil. São Paulo: Companhia das Letras, 1994.

MORIN, Edgar. X da Questão: $O$ sujeito à flor da pele. Trad. Fátima Murad e Fernanda Murad Machado. Porto Alegre: Artmed, 2003.

NOGUEIRA, Franco. O Estado Novo. Porto: Livraria Civilização Editora, 2000.

ORLANDI, Eni Puccinelli. Vozes e contrastes: discurso na cidade e no campo. São Paulo: Cortez, 1989.

UNICAMP, 1997.

. As formas do silêncio: no movimento dos sentidos. 4 ed. Campinas: Editora da

PÊCHEUX, M. Semântica e Discurso - Uma Crítica à afirmação do Óbvio. Trad. Eni Orlandi, L. Chacon, M. Gonçalves Corrêa e S. Serrani. Campinas: Editora da UNICAMP, 1988.

PONTE, Cristina. Leituras das notícias - Contributos para uma Análise do Discurso. Lisboa: Livros Horizonte, 2004.

PRETI, Dino. (Org.). Interação na fala e na escrita. São Paulo: Humanitas, 2002.

. O discurso oral culto. 2 ed. São Paulo: Humanitas, 1999.

. Sociolingüística - Os Níveis de Fala. São Paulo: Edusp, 1994.

REVISTA ÉPOCA. São Paulo: Editora Abril, n. 5037 jan. 2008.

RIBEIRO, Branca Telles e GARCEZ, Pedro M. (Org.) Sociolingüística Interacional. 2 ed. rev. ampl. São Paulo: Edições Loyola, 2002.

SANDBROOK, Dominic. A irrelevância de 1968. Disponível em: <www.uol Mídia Global htm>. Acesso em: 16/05/2008.

SANTOS, Irenilde Pereira. A memória no Discurso do Auto da Compadecida. In MICHELETTI, Guaraciaba (Org.). Discurso e Memória em Ariano Suassuna. São Paulo: Paulistana, 2007. 
SANTOS, José Rodrigues. O Correspondente de guerra, o discurso jornalístico e História: para uma análise da reportagem de guerra em Portugal no século XX. Lisboa, 2001. Tese (Doutorado em Ciências da Comunicação) - Faculdade de Ciências Sociais e Humanas da Universidade Nova de Lisboa.

SANTOS, Marcos Ferreira. Crepusculário: conferências sobre mitohermenêutica e educação em Euskadi. São Paulo: Zouk, 2004.

SAUSSURE, Ferdinand de. Curso de Lingüística Geral. 3 ed. Trad. Antonio Chelini; Izidoro Blikstein e José Paulo Paes. São Paulo: Cultrix, 1971.

SEGALLA, Amauri. Como a geração de 68 mudou nossa maneira de ver o mundo. Revista Época, 7 jan. 2008.

SILVA, Luiz Antônio (Org.). A Língua que Falamos - Português: História, Variação e Discurso. São Paulo: Globo, 2005.

SILVA, Marisa Torres. A Voz dos Leitores na Imprensa: um estudo de caso sobre as Cartas ao Director no jornal Público. Lisboa: Livros Horizonte, 2007.

SOUZA, Lusinete Vasconcelos. Gêneros Jornalísticos no Letramento Escolar Inicial. In: DIONÍSIO, Ângela P.; MACHADO, Anna R.; BEZERRA, Maria Auxiliadora (Org.) Gêneros textuais \& ensino. Rio de Janeiro: Lucerna, 2003.

SOUZA, Pedro Diniz. A Dramatização na imprensa do "PREC". Coimbra: Imprensa de Coimbra, 2003.

- Voz do povo: Dramatização no discurso de um jornal revolucionário. Lisboa, 1998. Dissertação (Mestrado em Sociologia Aprofundada e Realidade Portuguesa, do Departamento de Sociologia) - Faculdade de Ciências Sociais e Humanas da Universidade Nova de Lisboa.

SZESZ, Christiane Marques et alii (Org.) Portugal - Brasil no século XX-Sociedade, Cultura e Ideologia. Bauru: EDUSC, 2003.

TELES, Viriato. Zeca Afonso - As Voltas de um Andarilho. Lisboa: Ulmeiro, 2000.

TRAQUINA, Nelson et alii. A Tribo Jornalística - Uma Comunidade Transnacional. Lisboa, Notícias Editorial, 2004. . O Jornalismo Português em análise de Casos. Lisboa: Editorial Caminha, 2001.

VENTURA, Zuenir Carlos. A Globalização começou em 68. Revista Época, 7 jan. 2008. 
1968 o ano que não acabou. São Paulo: Editora Nova Fronteira, 1988.

VERDASCA, José. Memórias de um capitão. Lisboa: Universitária Editora, 2003. Entrevista: São Paulo, 1 dez. 2006. 


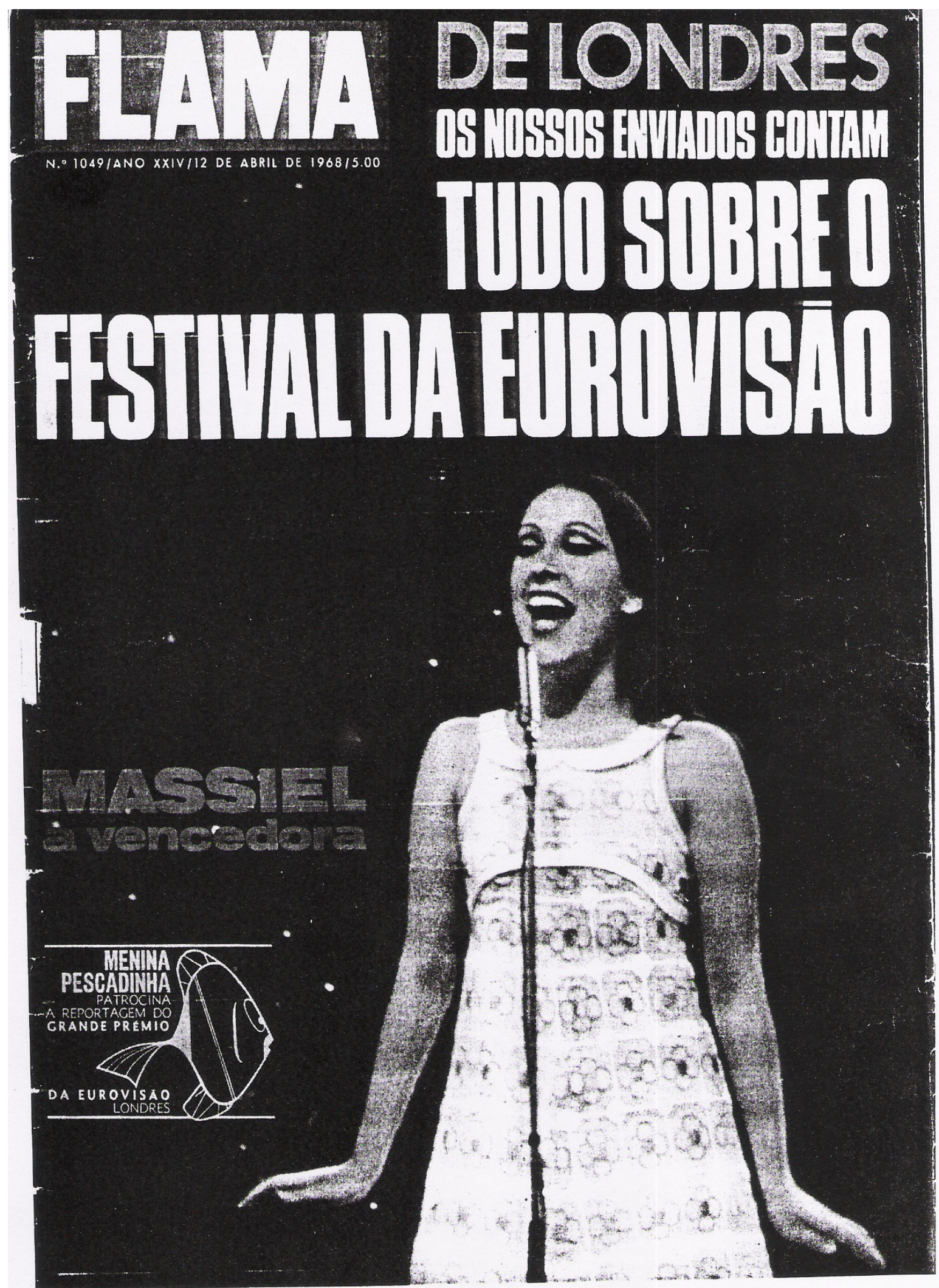




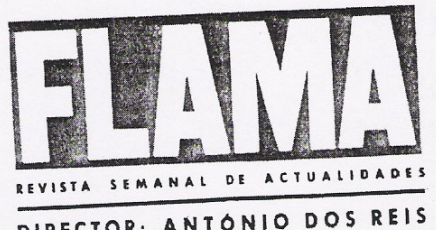

ANO XXIV - N. 1049 12 DE ABRIL DE 1968 - PREÇO $5 \$ 00$
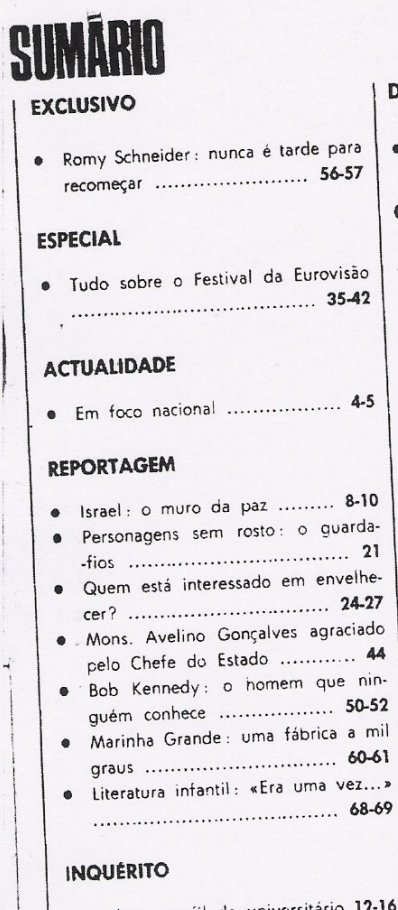

DESPORTO

- O sprint" final do campeonato 70

CRONICAS

RUBRICAS

- Cartas ao Director

- TV Procramas

- Krokòdeilos

- Palavras Cruzadas

- Humor

- Discos

- Flash

DA MULHER

Moda Primavera-Verão 68

$58-59$

CONCURSO

- 12: sorteio de at Quem

NA CAPA:

- VENCEDOR DA EUROVISAO

- Lisboa perfil do universitário $12-16$

EDITOR: ANTONIO DOS REIS C CHEFE DA REDACCÃO M. BECA MURALS / SUBCC

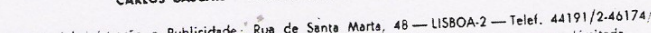

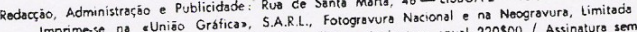

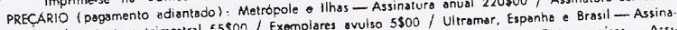
$110 \$ 00$ Assinatura trimestrol $55 \$ 00$ ) Exemplares

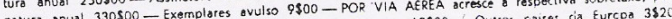

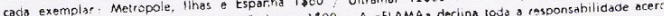

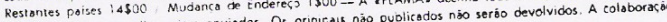
dos documenior que the seirm envindos. Os onginadita pela Direçso

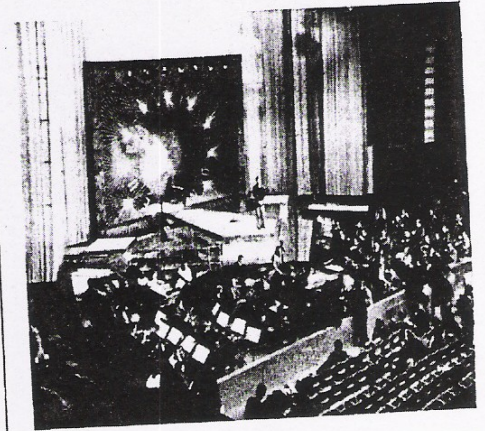

AOS LEITORES

Aparece esta ediçăc da nossa Revista em vésperas do domingo de Páscoa, dia em que a Igreja Catolica celebra a ressurreição de Cristo. Por isso, quere de Páscoa ciar esta «flamas com un leitores e anunFeliz para todos os nossos leitores ciantes.

A grande reportagem deste número retere-se ao Festival da Eurovisa. Para a realizar, a eflamas enviou a Múrias, e o Chere da Redackas M. Beça Murim lobo. seu reporter fotogracias a fim de acomque all estiveram ailo dias a fim destidores panharem, de perto, la canção internacio do famoso cerlame da canciaro uma excenal. Exigiu ainda este Oficinas onde a lente colaboraça (Fologravura Nacional Revista é te (For conseguir em tão curto Neogravura), para conseguras - manda espoço de tempo com capa e oito pá para a rua restival Eurovisäo realizado ginas do británica na noite do último sána capilat br conheca o campo das artes bado. Quem coŕ, certamente, o que esto grolizas ap Flamas representa de dina. mismo esforco técnico e económico. A nada nos poupámos na certeza de que as nossas largas dezenas de milhar de leitores saberào apreciar o nosso trabalho continuara a dispensar-nos a sua simpatia agora, se possivel ainda maior, ao apro. ximarem.se as Bodas de Prato da uflama. 


\section{GRANDE PRÉMIO EUROVISÃO DA CANÇÃO MASSSEL:AVITÓRIA AONDSSOLADO}

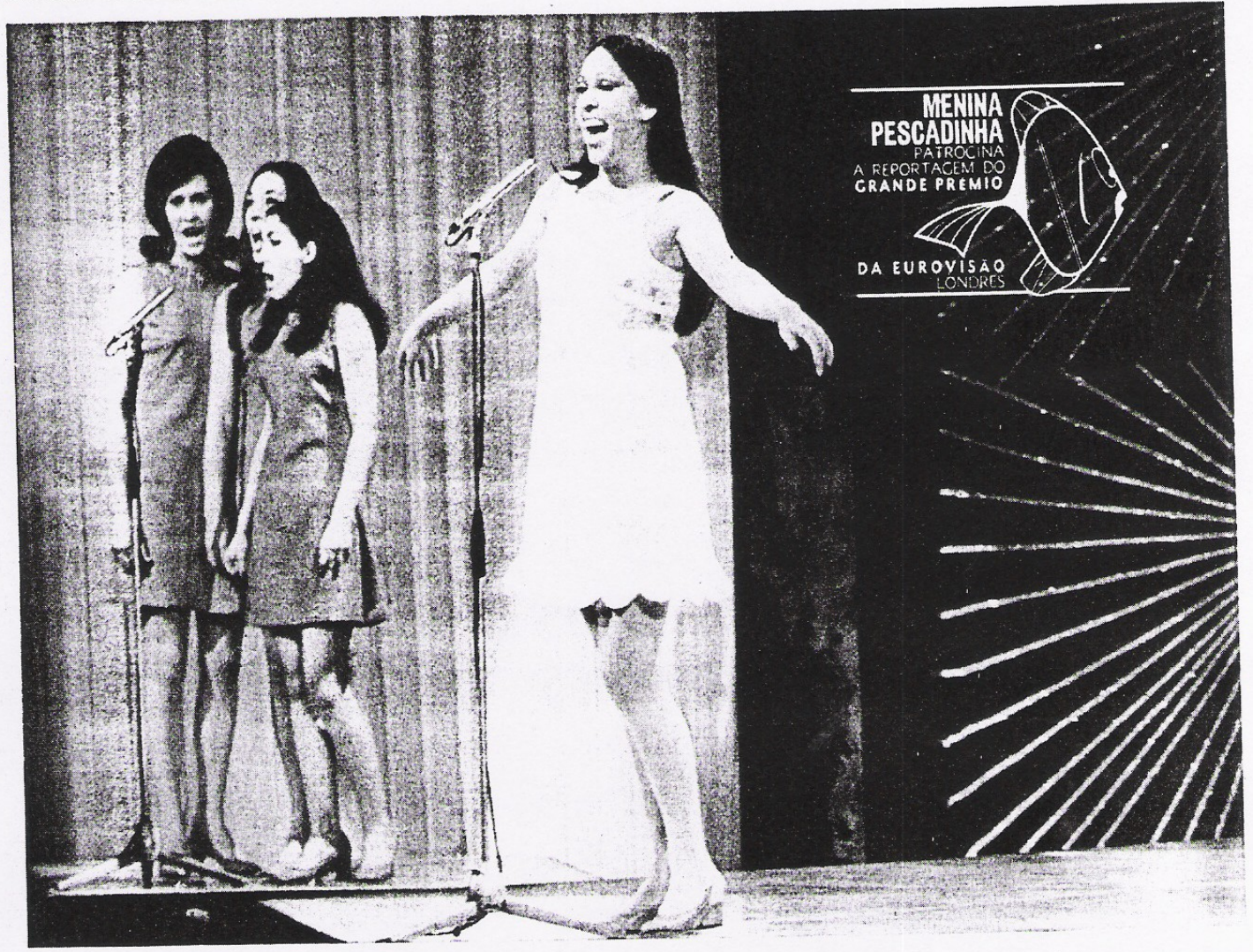

REPORTAGEM DOS NOSSOS ENVIADOS M. BEÇA MÚRIAS E JOAQUIM LOBO

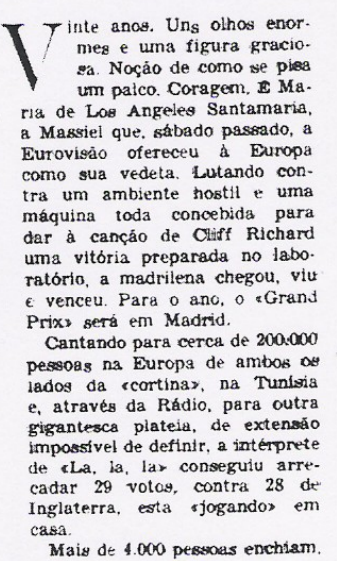

por completo, o Royal Abbert Hall, da platela es galerias. Massiel, ernbora sentindo hostilidade que a rodeava, parecia ser a mais caima da comitiva

Entre bastidores, momentas antes de atravessar o simbolo da Eurovián con dez inetron de altura que servia de fundo a decoraça da cena. annda enconthaloer com as componentes do trio de suporte. Mas seja-m permitida aqui, unua opiniáo. perce recessat a cente mulo pessoal: arrebatou para a Eppana XIII da Canḉo. O magnifico trovador cataláo, ao recusar-se, especta. cularmente, a cantar em cast thano a melodia com que anues. tros hermanoss viram a conquis. tar o troféu deste ano, conor guiu estas duas colsa.s - che. mar a atençáo do mundo inteiro para sLa, la, la $e$, por outro lado, obrigar a TVE a lanş a melindroua tarefa a irre do a melindrasa taresas a salerosas Massiel.

Ouvir, pela primeira vez, a sua Ouvin, pela prim Ramo a pequir e Manuel Calva Ramon Arculr e Manuel Calva

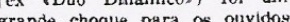
de guanto uaviam habituado eseutar o menino poeta de Bar. celon

Imedatamente, eu e muitos outrog fornalistas e criticos de todo o mundo que, no Royal Alter Hall, seguiram um por um os compassos das ensaios e secextho - cinco dias de puante de preparaupenas, hora o mela de espectáculo -- fomos levados a um juizo precipitado. A versa - Massiel tem muito menos ni. vel artistico do que a de Serrat. logo a Espanha perde. Puro en gano. A versão Massiel tem ob damente, musto menos nived ar ustico do que a de Serrat, logo a Espanha ganhou.

Com a sua sobriedacte de pro cessos, Joan Manuel jamais teri. batido Cliff Richard e a fabuB. B.

turno, teve a ajudá-la a publicidade causada pela renúncia do cataláo. A Imprensa lnternacional, embora, em muito: casco, tivesse atribuído razoes politicas no caso-sernat. também nảo deixou de elogiar o mérito da espanhola que, em quinze dias, se preparou para tão melindrosa tarefa

A chegada à capital inglesa. Masslel vinha um tanto nervo. sa, receando. certamente, que ov

reporteres a metralnasen 


\section{MASSIEL; 15MILDLLARES POR3MINUTOS}
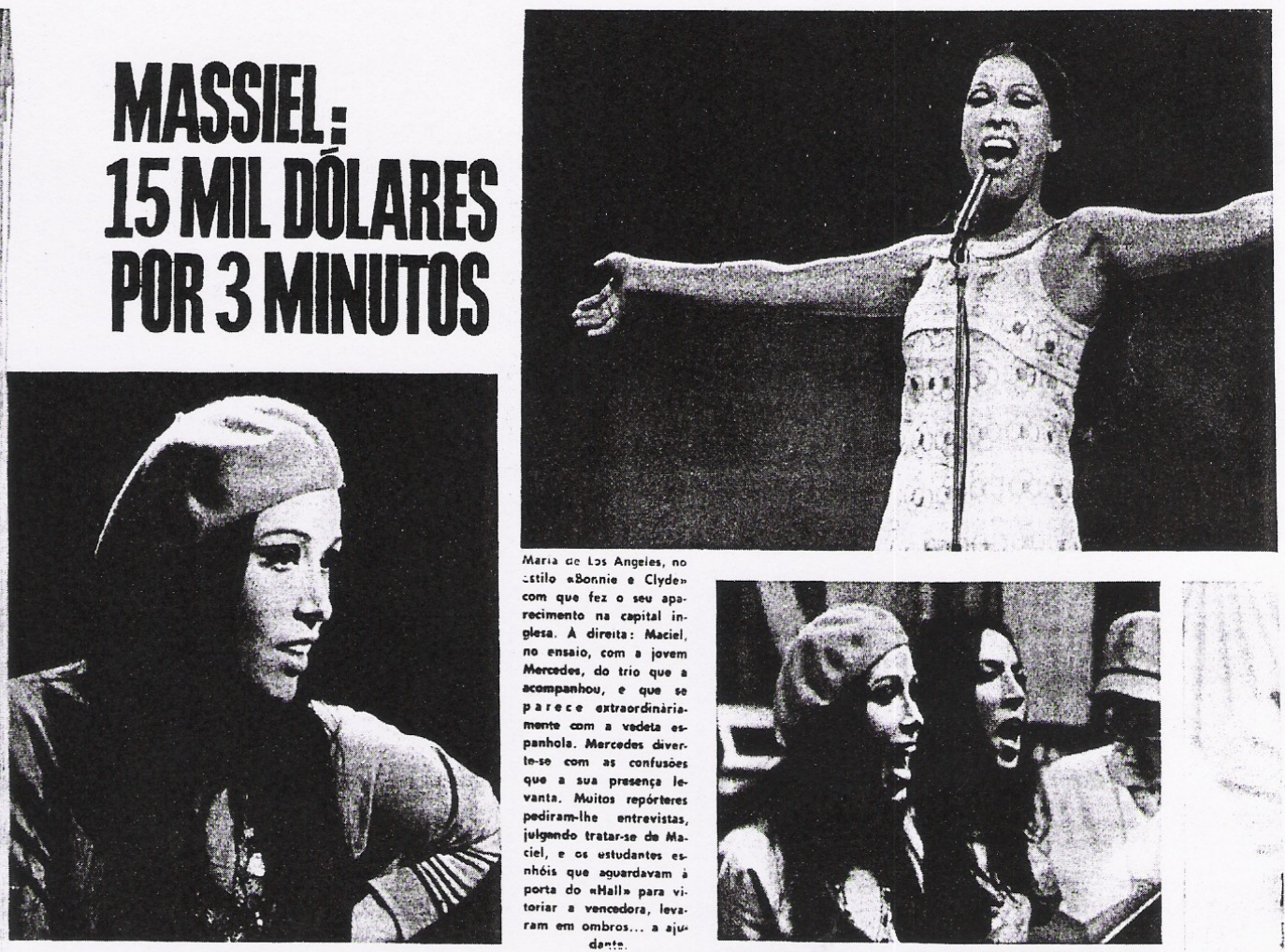

Maria ae Los Angeies, no com que fez 0 clyou apa. recimento na capital inglesa. direita: Maciel, no ensaio, com - jovem Mercodes, do trio quo a acompanhov, - que se parece extraordinario. panhola, Mercedes dis or to-so com as confusoes que a sua prasença lo. vanta. Muitos repórteres pediram-lhe entrevistas, ciel, e os ustudentos nhois que aguardaram a porta do nHalls para viram em ombros... a siw.

Assim não aconteceu, tanto hais gu os bitanicos nais dedicaram pésme. ao acontecimento, atirando com Cliff Richard para a primeira página. A BBC sdespejayas, $\$$ bre a Europa; "Congratulations" 40 vezes por dia! Mas ta-se $f a$ lando (e trauteando) o eLa, la, las por esse continente fora, e colo e quals conta para um televisivo As o rand Prix, thores, ou sploness puardam mais ou mencis. mente no ouvido do publico ta to por causa das vendas como por causa dos votos. E não há dúvida que a mesma cançảo, na voz de Serrat, estava arriscada a ter sorte identica à espléndida balada de R. Deco que Claude Lea sam penga que os que pospelo menos preentemente certame onde a qualidade pura possa sobrepór-ke ao chamado valor comercial. Foi isto que Massiel veio trazer de novo a

- Estou contentisoma, ma sinto sobre mim o pero de um nova reapomerabilidade $A$ minh vitoric é de todos as canconets. tas jonens de Espanha, de tod a juventude do meu pair.

Estas as palavra pue pronun. ciou, para a a Flamaz depois de col para a rimas, depols de acac uma vez sido todo 0 vera de res jornais, noticiosas, operadore de cinema

- Estava no Mesrico, no decur so de uma digressáo pela América do Sul, quando recebri um te legrama da TVE. Expticavam - me que etinha havido um com tratempos e que era forcaso qu "u vollasse o mais depressa pos. sivel, para tomar o lacgar de Joan Manuet Serrat. Fiquei espantada Larguei todos os contratos que mha - perdendo, derra forma. chegada a Madnid soube do mati.
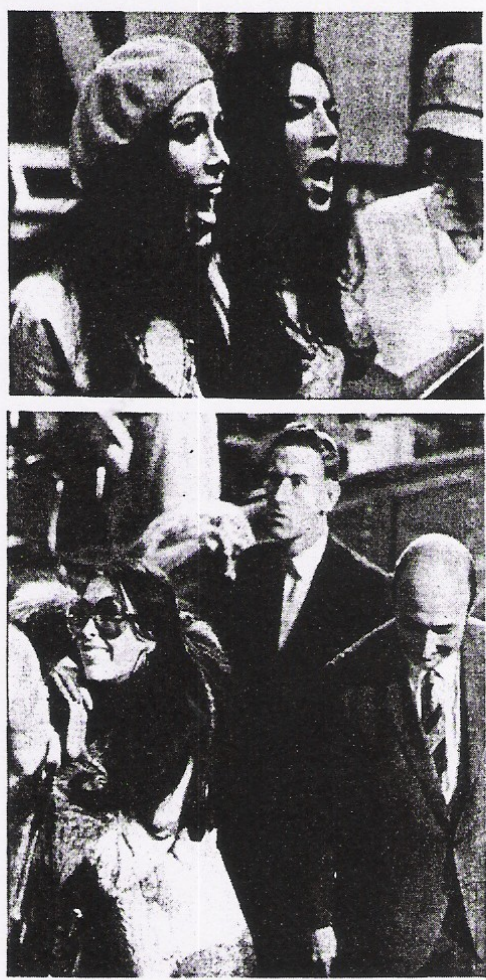

Massiol, sorridente, num intervolo (c)

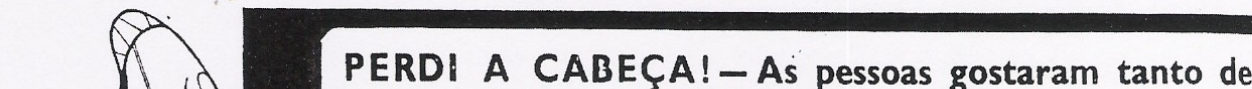
para um almoço grátis (aliás não só para um, mas pa as minhas embalagens. Com 20 vales, no valor de $10 \$($ de peixe congelado à vossa escolha. 

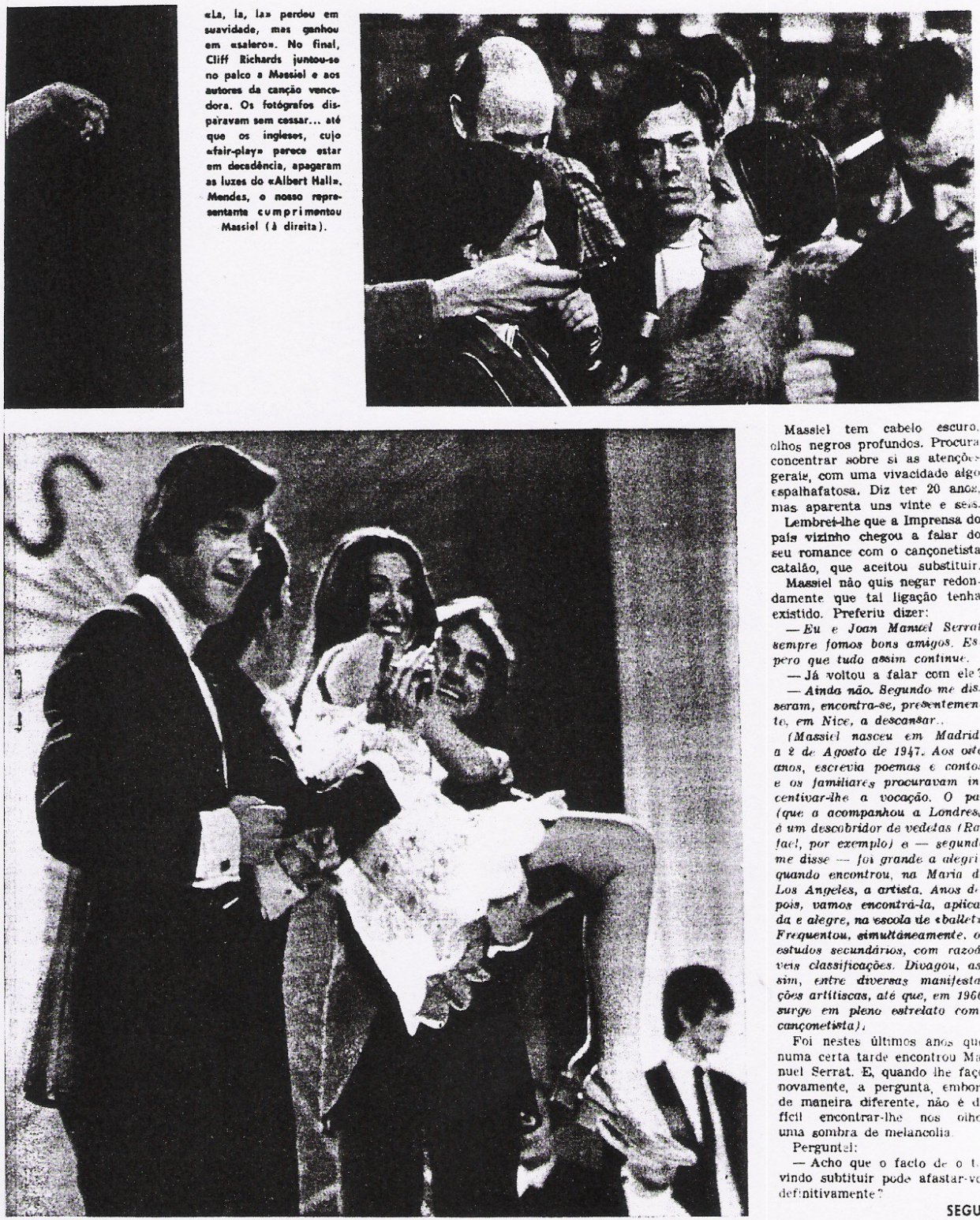

Masslel tem cabelo escuro.

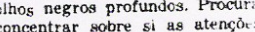
gerait, com uma vivacidade algo espalhafatosa. Diz ter 20 ano: mas aparenta uns vinte e setis. Lembreithe que a Imprensa do pals vizintho chegou a falar $d o$ seu romance com o cançonetist catalao, que aceitau substluir. Mente pue tal ligacá tenh existido. Preferiu dizer:

- Eu e Jonn Manuel Serrat sempre fomos bons amigos. Es. pero que tudo assin continue. - Já voltou a falar com ele? - Ainda näa Segundo me dis. scram, encontrarse, presemtemen16, em Nice, a descansar

a diss nasto de anos, escrevio poemas as onto e os familiares procuravam in. centivar-the a vocasaio. o pat (que a acompanhou a Londres. o um descobridor de vedetas $I R a$. fael, por exemplo) e - segundt me disse -n for grande a aregri quas a theontrou, na Maria de pois, vamas encontri-da, apdicada e alegre, na coscola de sbaliet Frequentou, simutareamente, as estudos secundirios, com razodvets classificaços. Divagou, assim, entre diversas manitestaçồs artitiscas, ate que, em 1966 surges em pleano

Foi nestro altumcs an numa certa tarde ancontou que nuel serrat. E, quando the faça novamente, a pergunta embor de maneira diferente, năo è di ficl encontrar-lhe nos who una sombra de melancolia

Perguntel:

- Acho que o facto de o 1.

def:nitivamente?

e mim, foram tão simpáticas, que este ano resolvi convidar toda a gente vara muitos). Para isso, basta juntar os vales de $\$ 50$ que acompanham $\$ 00$, basta ir a qualquer posto do S. A. P. P. e trocá-los por igual valor 


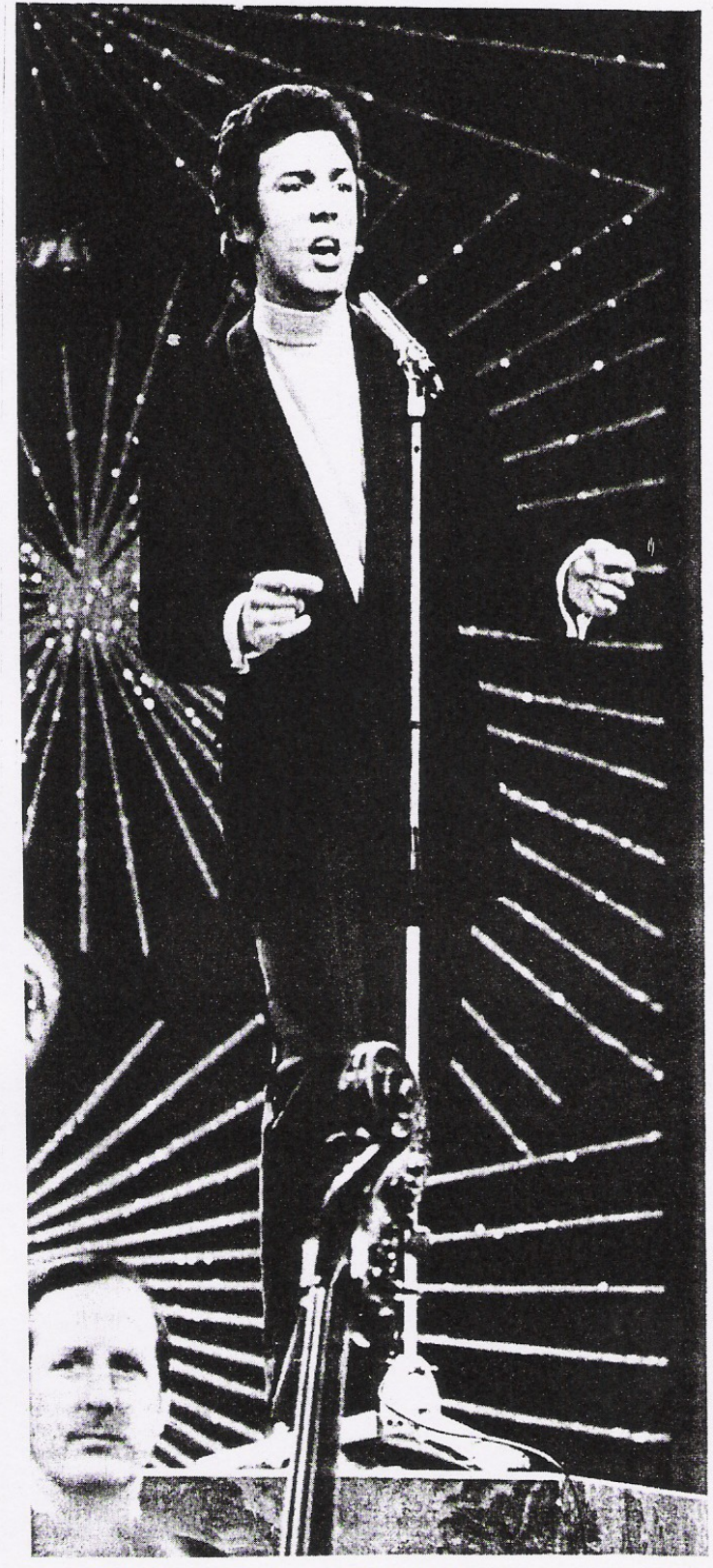

\section{CARLOS MENDES: COMPROU EM LONDRES ACAMISOLA DO FESTIVAL, PRECO:70ESCUDOS}

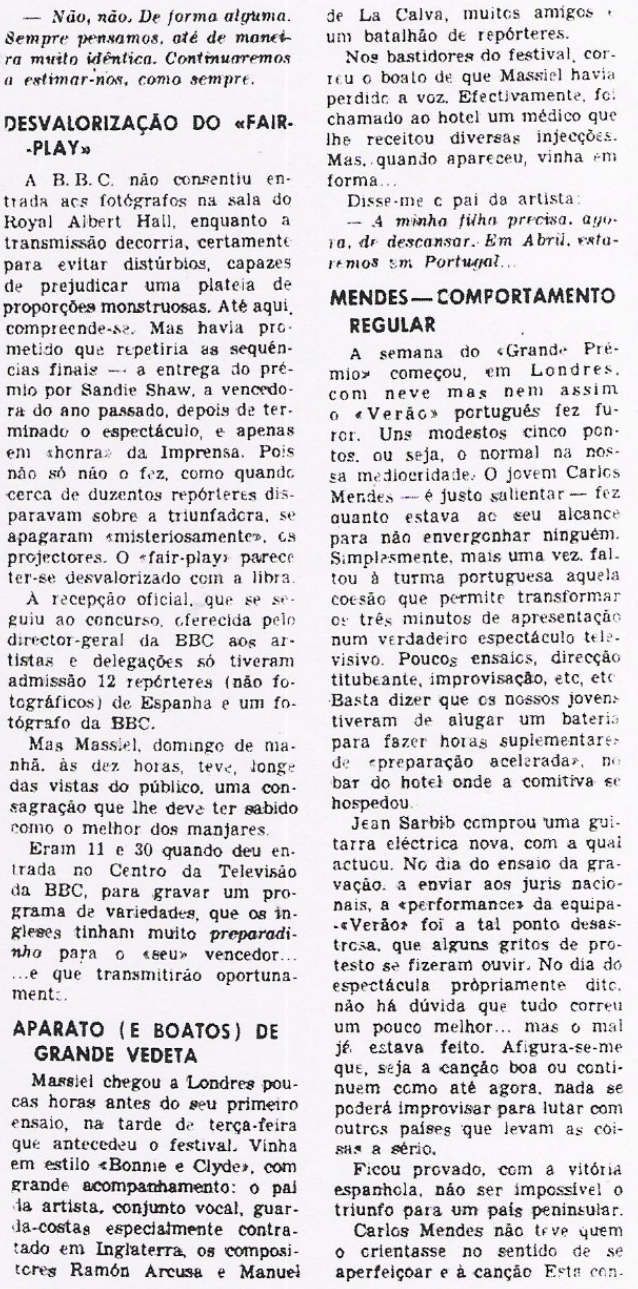

La Calva, muitos amigos mi batalhăo de reporteres. Nog bastidores do festival cor

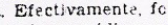

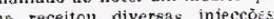
as guanio apareceu, vinha in Disse-me c pai da artist

DES- COMPORTAMENTO ortugués fez fu cinco pon a mediocridade: O joven Carics Merdes - e Justo salientar- te, mals una vez. fal. de apresentaçá ireça 列, et Basta dizer que os nossos joven para f8zer horas suplementar

Jean Sarbib comprou uma gy tarra eléctrica nova, com a qua actuou. No daa do ensaio da granto desa
os de propac ha duide que um pouco melhor... mas o mal estava feito. Afigura-se-me puem até agora, nada se poder improvisar para lutar com ats a sério.

ado, com a yitória

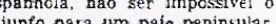
- crientasse aperfeiçoar e à cançáo Est? con.

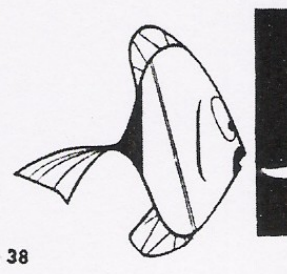

Para os comedores de pescadinha, esta é uma grande noticia. A popular menina Pescadinha (também conhecida por Pescada $n .^{\circ}$ 1) brinda os seus fiéis apreciadores com o peixe para um almoço de toda a familia, completansente grátis. 


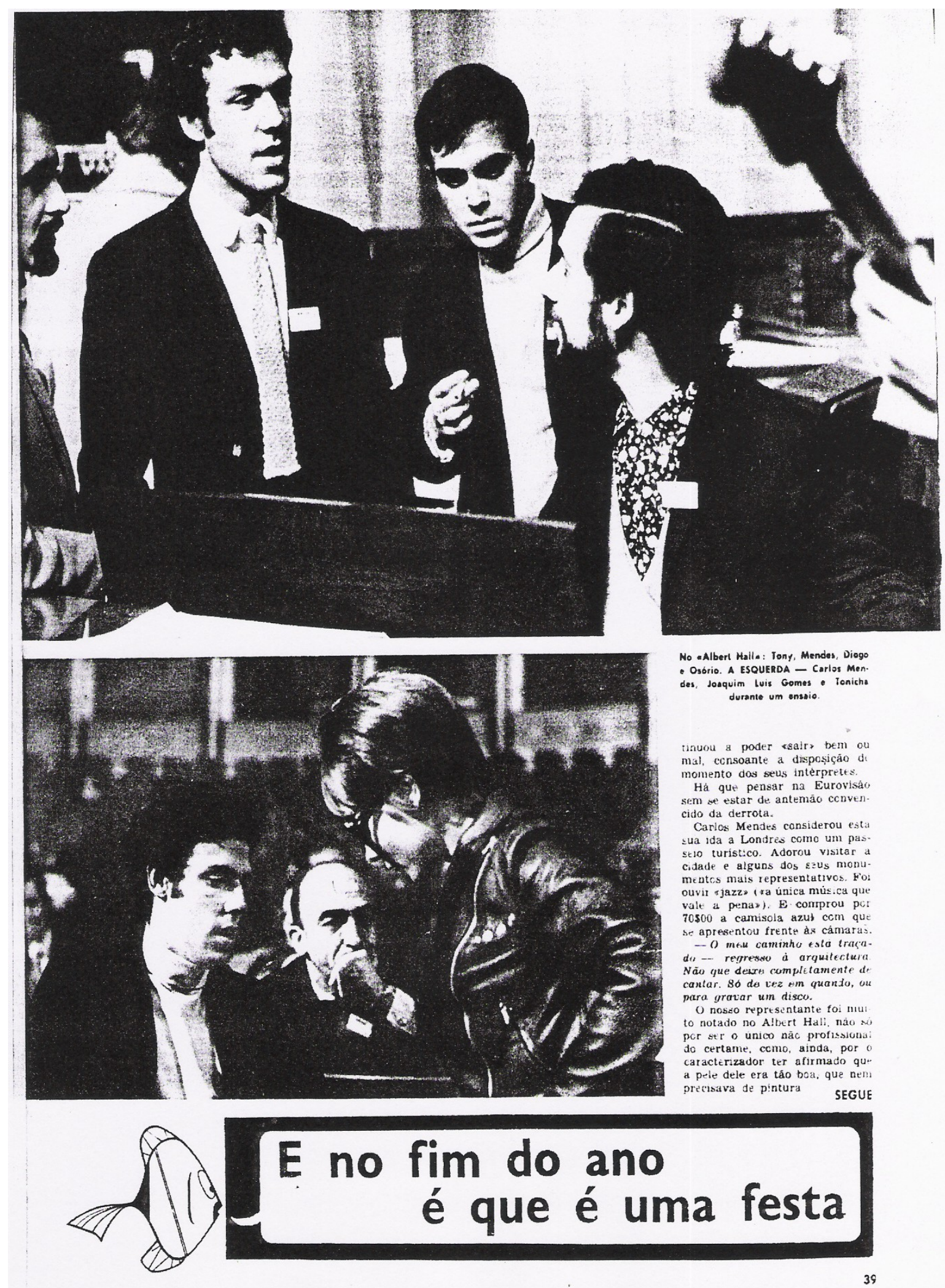



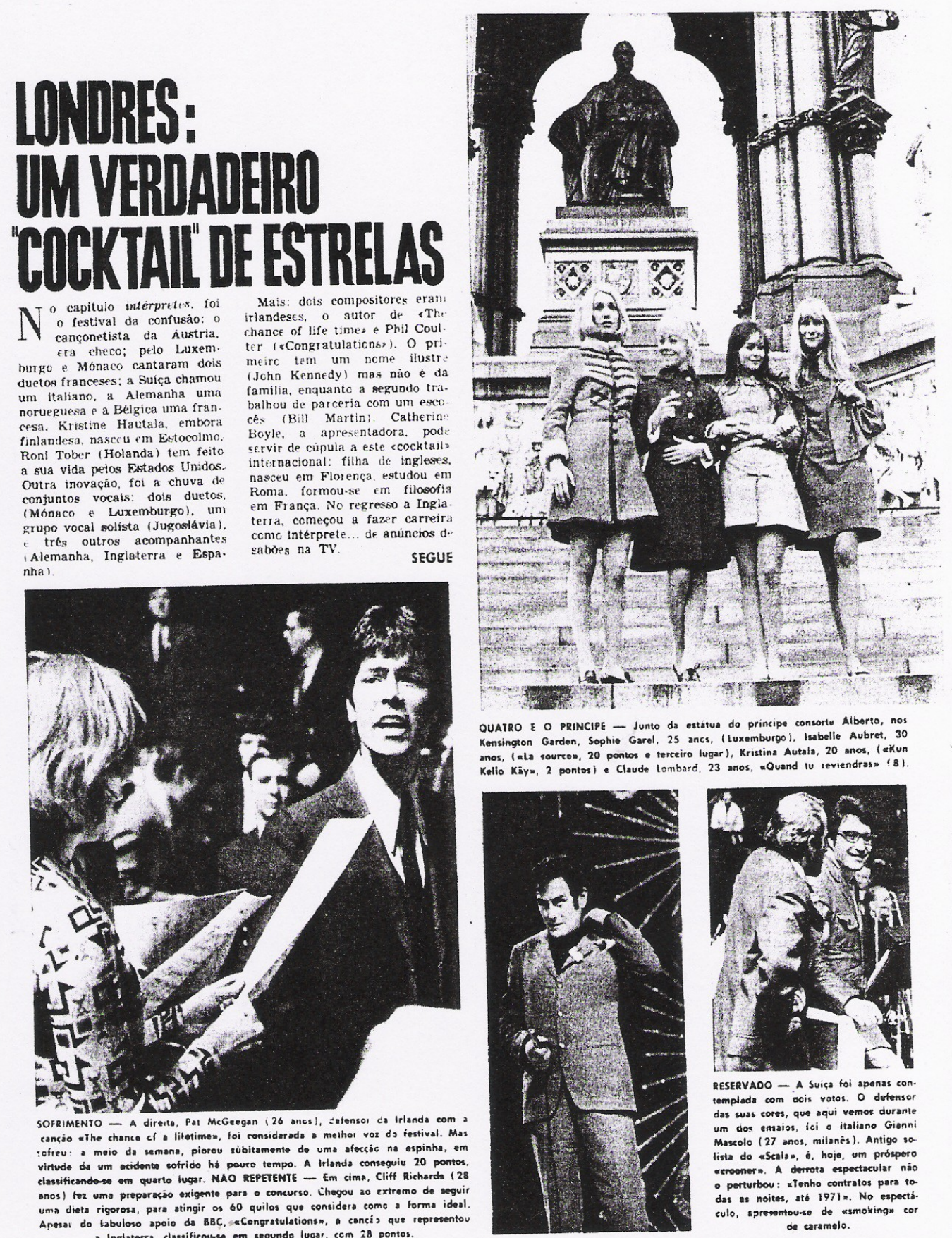

RESERVADO - A Suica foi aponas con. templeda com aois votos. O defensor das suas cores, que aqui vermot durarte Mascolo ( 27 anos, milanés). Antigo so lists do escaiss, is, hoje, um probsporo ecrooner m. A derrota espectacular nio - perturbou: stenho contratos para to das as noites, at 1971 . No espectio evilo, ipreormtouse de ssmoking" cor

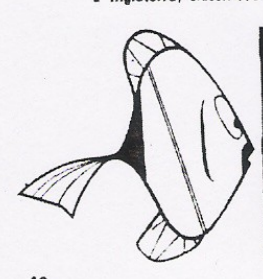

Quero dar felicidade a muitos milhares de amigos e admiradores. Todos os vales têm também uma senha numerada, que habilita a um grandioso sorteio. 

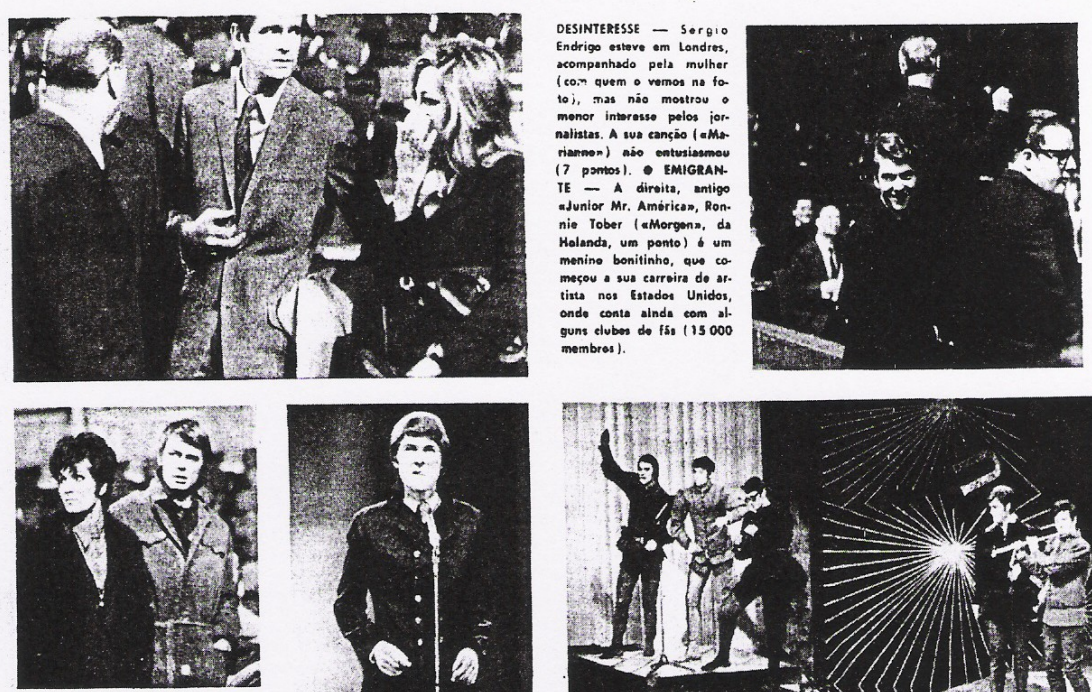

NO PALCO E NA VIDA - Encontra.

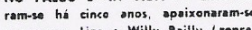

sententes do Monaco com a molodia uA

ram bem ionge do exito

bis

300 o reflexo da noss vida. Esta o agr.

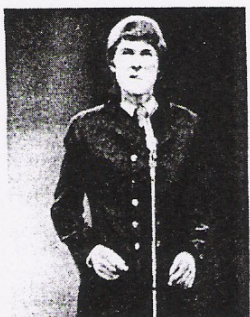

IE-1E - No wes incomproensivivi: arro.

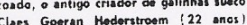

aprosentouse frente os càmaras da TV

prida fochave com oito boties dourados

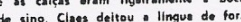

daroness de veres em tribs minution (15

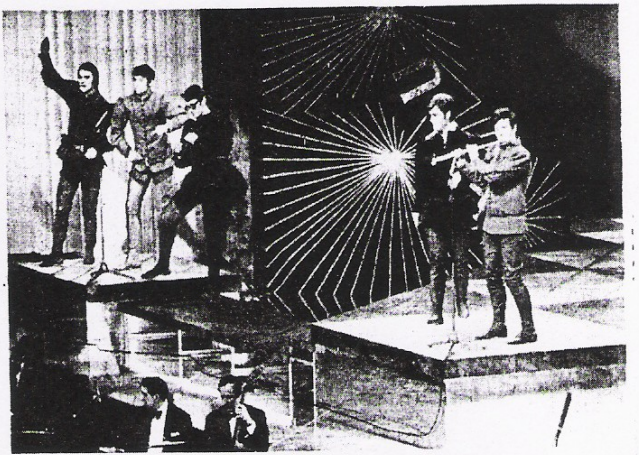

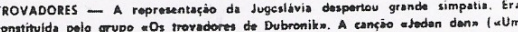

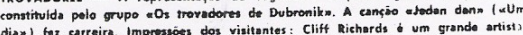
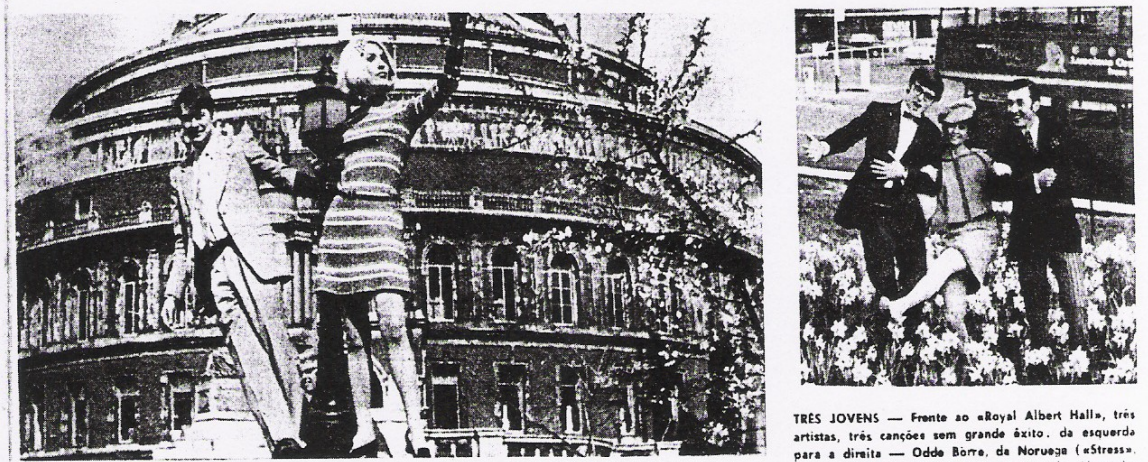

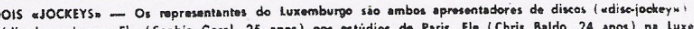

TDES JOVENS - Franto so aRoyal Albert Halls , wh

artistas, trís cancioee sem grande axito. da esquerd

2 pontos ): Woncke Myhra, 20 anos, de Aleminn

(atin Hoch der Liebes, 11 pontes) : Karal Gon burgo. aNout vivrons d'amours obteve apenas cinco pontos.

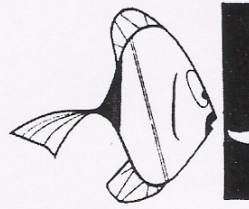

Guardem a senha, guardem quantas senhas quiserem, que talvez the caiba um dos 10 Automóveis,

10 frigorificos, 10 televisores, 10 aspiradores,

10 enceradoras, 10 secadores, 10 máquinas

de barbear, 10 torradeiras, 10 panelas de pressão,

100 transistores e milhares de outros prémios. 


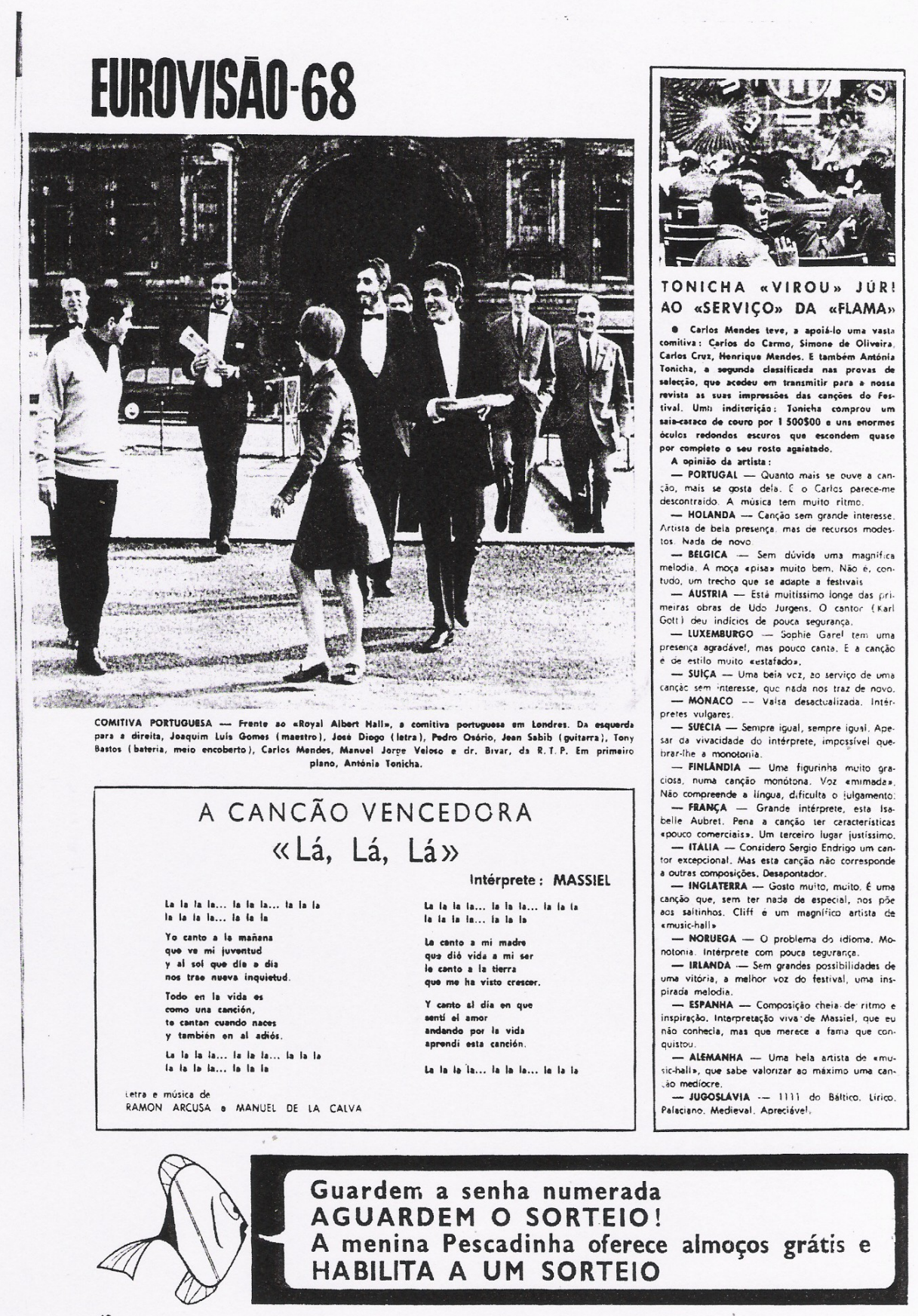

42 

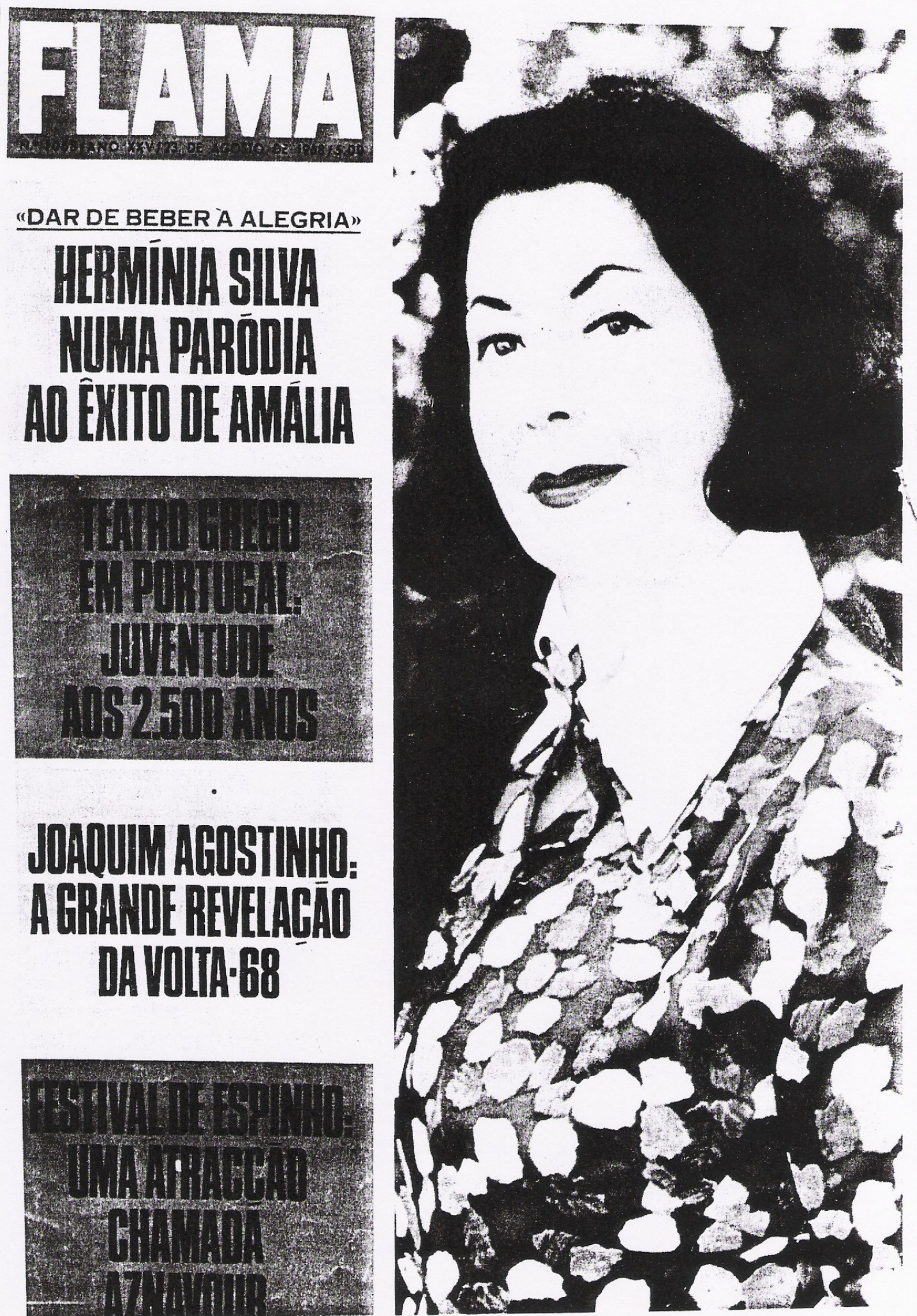

"DAR DE BEBER A ALEGRIA" HEPMINIIIIIIA NUWA PARODIA AD EXITO DE AMALILA

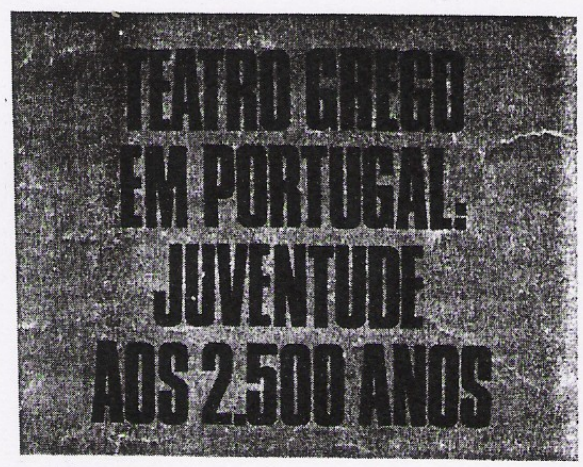

JOAOUIM AGDSTINHO: AGRANDE PEYELAGEAO DAVOIAABP

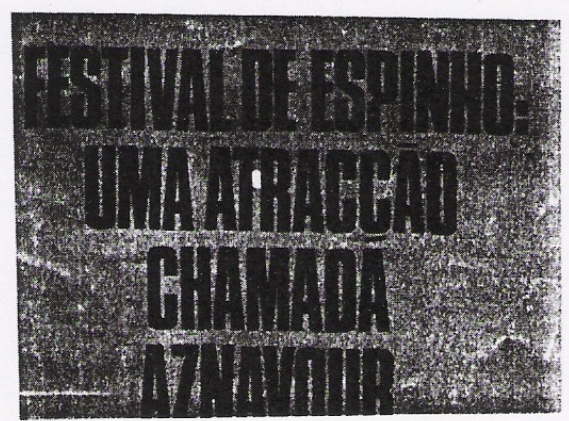




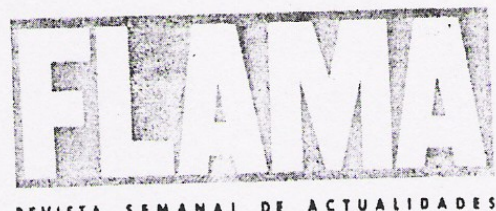

REYISTA SEMANAL DE ACTUALIOADES

DIRECTOR: ANTONIO DOSREIS
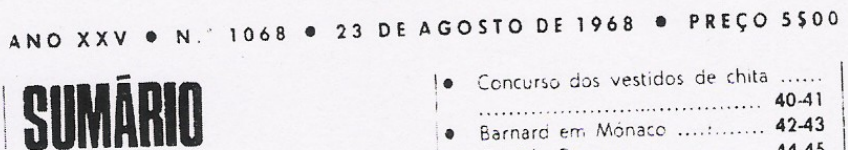

- Concurso dos vestidos de chit

- Barnard em Monaco ........... 42-43

- Corrida Gcyesca ................ 44.45

ESPECIAL

- Continuação da história de Robert Kennedy por Oriana Fallaci...50.53 50.53

ACTUALIDADE

- Em foco 6.9

REPORTAGEM

- Eça de Queiros permanece vivo em

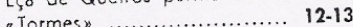
"Tormes" José Manuel Nunes: iocutor insatis. teito

- Teatro grego em Portuga! ...... 16-19

- Inquerito fim de semana ... 20.21

- Charles Aznavour em Espinho

- Charles Aznavour em Espinhe 24-25

Joaguim Agostinpo: revelação da Volta-68

- Herminia Silva: Dar de beber a ale gria ............................. 36.37

CRONICAS

- Medicina

- Toiros

- Cinema

46

RUBRICAS

- Tema nacional

- Cartas ao Director

- Fotograte os seus filhos

- Discos

Crocodilo

- Desenrie un carro

- Palavias Cruzadas

- TV Programas

- Humar

DA MULHER

- Actualidades femininas .........56.57

NA CAPA: HERMINIA SILVA

EOITOR ANTONIO DOS REIS CMEFE DA REDACC,AO. M. BECA MURIAS SUBCHEFE DA REOACCAO CARLOS CASCAIS FROFRIEDACE CA UNIAO GRAFICA SARL.

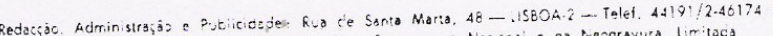

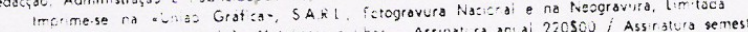

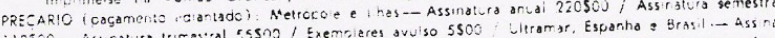
losco Ass ra:

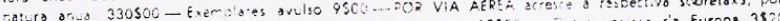

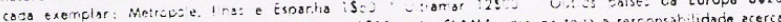

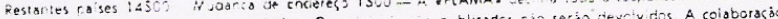

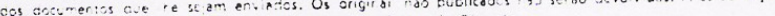

eramenta e cedica vela Direcsi
EM ANGOLA COM OS SOLDADOS Uma equipa de reportagem da Flama, constituída pelo redactor Silva Pinto e pelo repórter fotográfico Joaquim Lobo acaba de passar um mês em Angola, que percorreu de Norte a Sul, ouvindo militares e civis, brancos e negros. O resultado do seu trabalho aparecerá no próximo número da nossa revista, em vinte e quatro páginas de flagrante oportunidade, de jornalismo objectivo, sobre a guerra que já perfez sete anos. 


\section{HERMINIA SIIVA "DAR DE BEBER A A ALEGRIA"}

Depois de Amália «dar de beber à dor», Hermínia «dá de beber à alegria» num novo, disco que sairá dentro de dias.

Truto de rivalidade com Amá- lia? Nada disso. Se em popularidade, elas têm riva lizado, pessoalmente respeitam-se e admiram-se como profissionais do mesmo ofício.

- A Amália é umba «coisa» maravilhosa que năo tem expli. cação. A gente gosta e pronto náăa é possivel explicar mais. Eu näo é possivel explicar mais. Eu
sei que o público nos costuma associar; quando vém ter comigo falam-me sempre dela e Amáli tamberm me diz que the falan sempre em mim. As vezes, con fessam-me $\hat{E}$ da senbora $e d$ Amália que en gosto mais Em bora boje, baja bora boje, baja asm grut pazes e raparigas que can ravilhosamente o fado, eles gos tam de nós talvez porque traba thámos no teatro muito tempo e ja cá estamos há um bom par de anos. Quando a Amália se es treou no teatro de revista, disse Gostava mesmo de trabalbar com a Herminia. Vieram-me bus. car e eu aceitei. Fazia primeir. car e eu aceitei. Fazia primeira
figura, ela segunda. Ambas temos maneiras diferentes de cantar o priblico é que o diz, bá coisas que nós não sabemos explicar cada uma à sua maneira, conquis támos o nosso príblico. Aparece mos muita vez no rearo de re vistas Amalio es amo reatro de ree camarada, quando fala de mim põe-me nos pincaros da lua, ell nem me refo tanto.

Hermínia exprime-se as sim acerca de tudo e de todos. Há nela uma vontade grande de não querer ferir ninguém, de agradar a toda a gente. Por isso, a paródia
ao fado da Amália (no mesmo disco há mais duas, uma ao Quarteto. 1111 («Dona Urracan) e uma rapsódia de folclore) esta numa velha linha do reportórió de Hermínia: a das caricatura de fados sérios, como o aFado mal Falado», o "Fandango Inter-

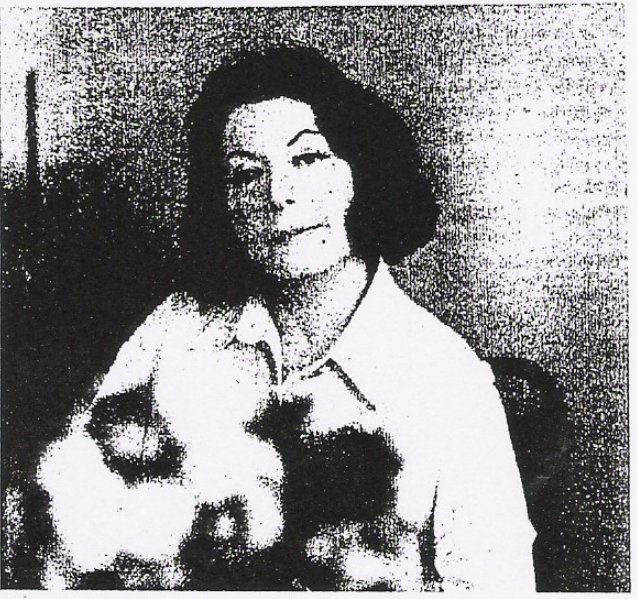

Equanto puder, Herminia Silva continuarb́ - cantar o fado, naquele seu estilo muito próprio, que a tornam inconfundivel.

nacionaln, e outros. Porquê em Herminia este gosto pela carica tura? Desde o início da sua ca reira que actua no teatro de revista. $\mathrm{E}$ as paródias surgiam na turalmente. Mas coincide esse facto com um gosto peia carica-

- São coisas que desempenba mos, sem saber porquê. As vezes, saem bem. Sinto-me bem a cantar assim. E claro que se me dessem os nicmeros sérios logo de inicio, eu cantava, mas eles afirmavam que eu tinha um jeitäo para estas "chargesn, e foram-me dando fados desses, artistas que cantasse sério havia muitos, e há. Eul, tam bém, canto fados sérios, mas as caricaturas são a minha especia lidade. O Villareb dizia que de pois de me ouvir no aFado ma faladon, ainda gostava mais de cantar o dele. Dizia que eut tinha uma maneira de brincar, que não.

REPORTAGEM MANUELA ALVE 30 magoava ninguém. Acbo que o fado deve cantar-se a sério, com sentimento. Concordo inteiramente com a Amália, que gosta de cantar sem luzes, e com aquel maneire que ela tem de fechor os olhos Sentese mairo lechar aquilo que se canta. Agora, se fado é alegre, olbando nos olhos do priblico $e$ vendo-o a rir $e$ mexer a cabefa e o corpo, entäo deve-se cantar com a luz toda. O contacto com o público atra vés da representaçāo esteve sem pre nos sonhos da fadista. Era ainda muito pequena, teria uns sete anos, andava na escola e já sonhava com o teatro.

- Imaginava-me no meio de muitas luzes, e eu a ser muito aplaudida, a receber muitas res. Tudo isso acontecen mas tarde. É verdade, tudo quanto so. nhei, se passou.

Contava, apenas, 13 anos quando começou a cantar. Foi no Par que Mayer, no Valente das Fa turas. Faziam lá revista. Hermínia cantava o fado, já representando. Uma vez, Alberto Ghira, man. dado dos Hortense Luz, foi convidá-la para ir trabalhar com eles. no Maria Vitória. Não aceitou, estava ali muito bem, nas Fartu. ras. Ganhava 55 escudos por dia, o que nāo era nada mau para 2 época. Ainda no Parque Mayer, passou para a Esplanada Egípcia; onde está agora o Teatro Capirólio Fazia-se revistas ao as livre - Nessa altura, era já vedeta. Tinba uns 14 para 15 anos. Es. treei-me, então, no Teatro Maria Vitória, numa opereta chamada "Fonte Sunta» Num fim-de-festa, tinba de cantar uns fados. Na peca a seguir "Feijäo Frader fiz numeros de revista e agradei imenso.

Trabalhou depois em vários teatros, entre eles o Variedades, onde substituiu Beatriz Costa, que partiu nessa altura para o Brasil. Desde então, ficou-lhe o gosto pelo fado representado, e aquele jeito de cantar, fazendo gestos com as mãos e comentários

- Já que não está escrito, im. proviso eu.

Criou um público. Um público que a tem aplaudido e manifes tado por ela muito carinho.

- Sempre me têm recebido bem. Ou cantando em casas particulares, ou em público, sempre me receberam carinbosamente. A vezes, vou na rua $e$ reconbeceme. - me. Até as criancinhas "Otha, aquela é a Herminia Silvas e vèm - pedem-me um aurografozinbo, que eu aceiro com muito agrado. que en aceiro com main agredo. fada nada a popularidade, atb. gosto.

Mesmo quando the levantaram boatos sobre a saúde da sua gargarre encarou o facto como fruto da popularidade, e do muito bem the quererem.

- Podemos constipar-nos, 10. mo qualquer pessoa e, se estamos SEGUE 


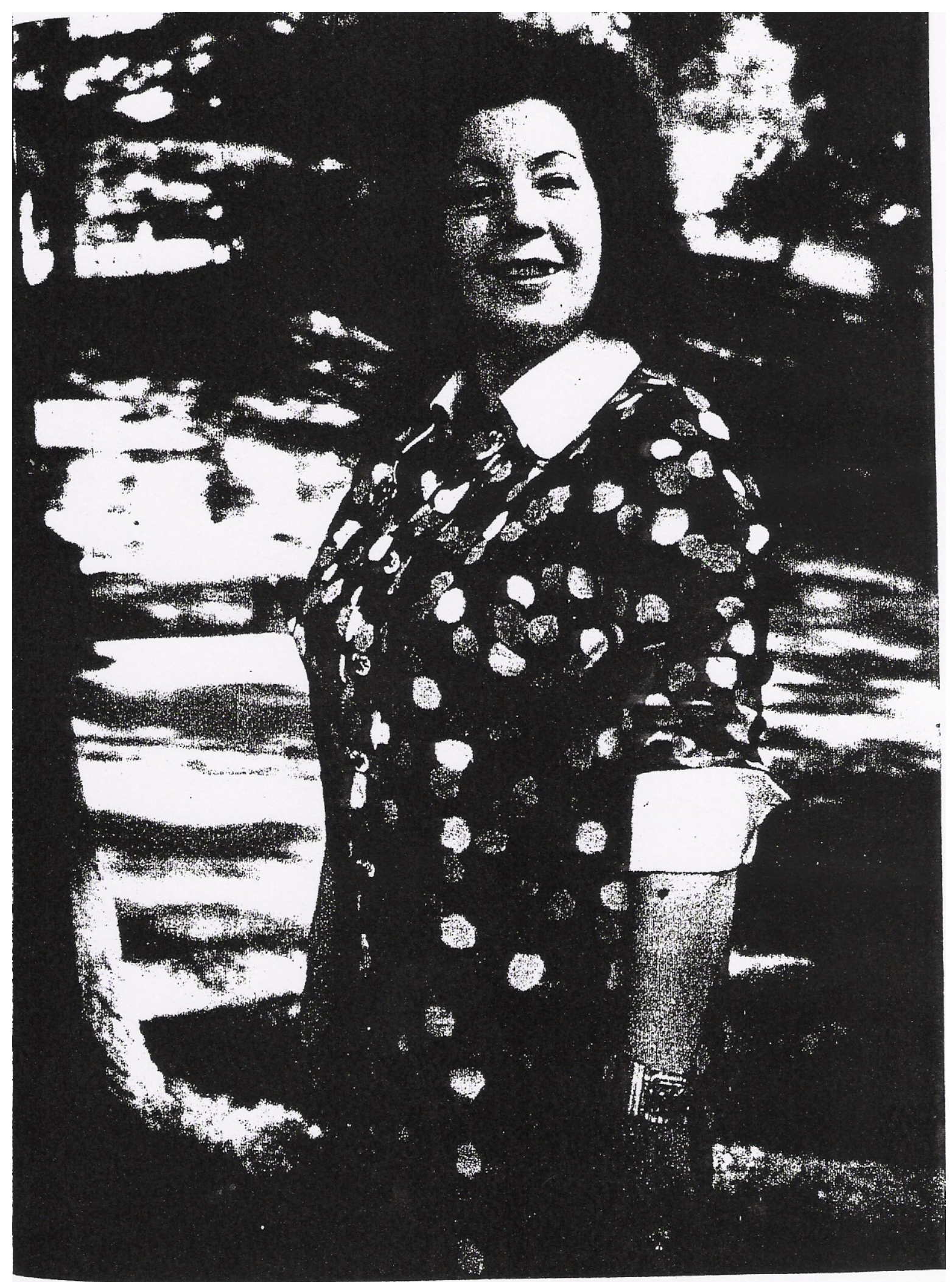


presos a contratos de revista, lemos que aparecer todas as noites. $\mathrm{Se}$ estamos indispostos $e$ năo nos saimos tão bem, o priblico, às vezes, não perdoa. Uma vez, cantava eu numa revista, adoeci, fui para casa com $39^{\circ}$ de febre. Estava muito rouca, cantava seis nimeros nessa revista, tive de ir para casa. Ao mesmo tempo, viram sair do teatro uma rapariga que la trat. balhava também, a deitar sangue pela boca. Logo pensaram que era eu. $O$ boato espalhou-se: $A$ Herminia não pode cantar, tem uma «coisan má na garganta." Também espalbaram que ell tinha uma garganta de prata quando imitava o trompete e a guitarra bavasiana. Mas como podia eu cantar, se isso fosse verdade? Pois se as pessoas que têm gargantas de prata, têm de lhes carregar por fora com um dedo, para faLar... Tudo isto foi por musto me quererem. Felizmente tenho sido sempre saudável, só às vezes me constipo.

Mas não fez mais imiraçōes. ( OO médico nāo aconselha as imitaçōes, porque é um grande esforço para as cordas vocais.x)

Nầo recorda maus exemplos na carreira. Só recordaçōes agradáveis.

- Na revista "Sempre em pé» fazia uma imitafão de Antigonaw. Todas as noites a Maria ninha Rey Monteiro, que come fava então a trabalhar com a mäe me is levar um ramo de flores. $E$ o sr. Robles Monteiro ia sempre ver-me às umatinées de domingo. Um dia, representava na opereta * Os Magalasn, no Teatro Apolo e foi chamada a artista Mari Maßos para dirigir os actores.

- Eu via a sr." D. Maria Matos fazer comentários aos meus cole. gas $e$ näo me dizia nada. Já an dava intrigada com aquilo. Um bocado acanhada, fui ter com ela $e$ perguntei-lhe porque näo me corrigia. Ela disse-me: Olba, minha filha, quando vamos tirar um retrato, sentamo-nos muito direi tinbas na cadeira. Depois, vem o fotografo e inclina daqui, levanta dali, puxa masis para lí. A posiçäo $j a \dot{e}$ muito diferente $e$ deixamos de ser nós. É como neste caso. Se eu the fosse mexer, deixavas de ser tu. Assim é que estás bem.

Presentemente, tem saudade dos bons tempos de camaradagem que passou no teatro?

- Teria, se quisesse voltar ao teatro e não me aceitassem. Então teria mesmo desgosto de näo poder reviver esses tempos. Mas nada disso se passa. Tenbo musitos convises para trabalbar no tea tro e bi mesmo empresários que, de cada revista que pensam apresentar, vêm propor-me trabalho. 32

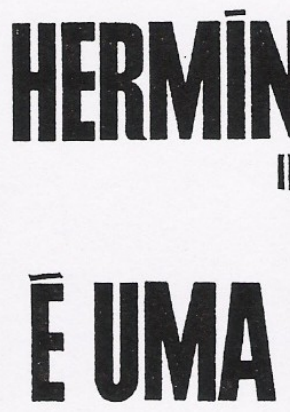

as como posso aceitar? As minhas duas casas, a de Benovente e o Solar, não me permitem outras ocupafões. Os clientes vêm cá, gostam sempre de me ouvir. Embora as minhas casas estejam já bem orientadas e tenba cá colegas que cantam bem, os clientes perguntam sempre por mim. Se uma vez out outra não posso can tar, ou porque estou muito cansada, ou não posso mesmo vir, eles ficam tristes $e$ eu também porque gosto de ver toda a gente satisfeita. Esta é a razäo por que só raramente agora trabalho no teatro $e$ por que não tenbo aceite os convites para actuar no estrangeiro.

Assim vive Hermínia actual mente: cantando na casa de Benavente e no Solar, convivendo com os seus amigos - gosta sempre de sentir muita gente à sua volta e de fazer bem-, frequentando quase diàriamente as "matinées" de cinema, e ajudando as empregadas em casa. Gosta de culiná ria, onde dá preferência aos petiscos nacionais: sardinhas ass das,' cozido à Portuguesa, entremeados com um pouco de cozinh francesa, em que aprecia muito os molhos.

Também gosta de ir às touradas. E mesmo muito aficionad e tem no meio tauromáquico a gumas amizades. Amadeu do Anjos, por exemplo. Eles e infortunado Quim Zé, foram pa drinhos de dois jovens cavaleiro da Moita. É assim Hermínia Silva generosa e amiga. Quando saíu de casa da irmã com quem viveu vários anos, e foi viver para casa própria levou consigo a mäe, um irmão, a sobrinha e o filho. Mais que irmä e tia, foi para todos como mãe.

- Casei-os - diz - como qualquer mäe casa os filbos: orientando-os, ajudando-os.

O filho, que tem boje 23 anos e é funcionário num banco, tem uma bela voz de lírico. Já tem actuado na Televisão e na Rádio. - Ele gostava de ter ido trabalhar no teatro, mas tireilhe a idesa da cabefa. Disse-lhe: $\alpha E u$ tive sorte, mas tu podes näo ter, é melbor tirares o teu curso. $E$ ele, que era bom rapazinho, tirou o curso comercial e empregou-se. Nunca abundonou o canto. Teve até liföes com $\mathrm{um}$ professor ita liano, mas nunca se lhe dedicava profissionalmente. Hoje näo sei se fiz bem ou mal em o ter contrariado. Olbe: já tinha que ser assim.

E uma mulher sem idade. Ela própria se quer defender assim. - As vezes dizem-me: a senhora já deve ter uns anozinhos... Sim, eut era pequeno, musiso pe queno, $e$ já a ouvia cantar.» $E$ ex

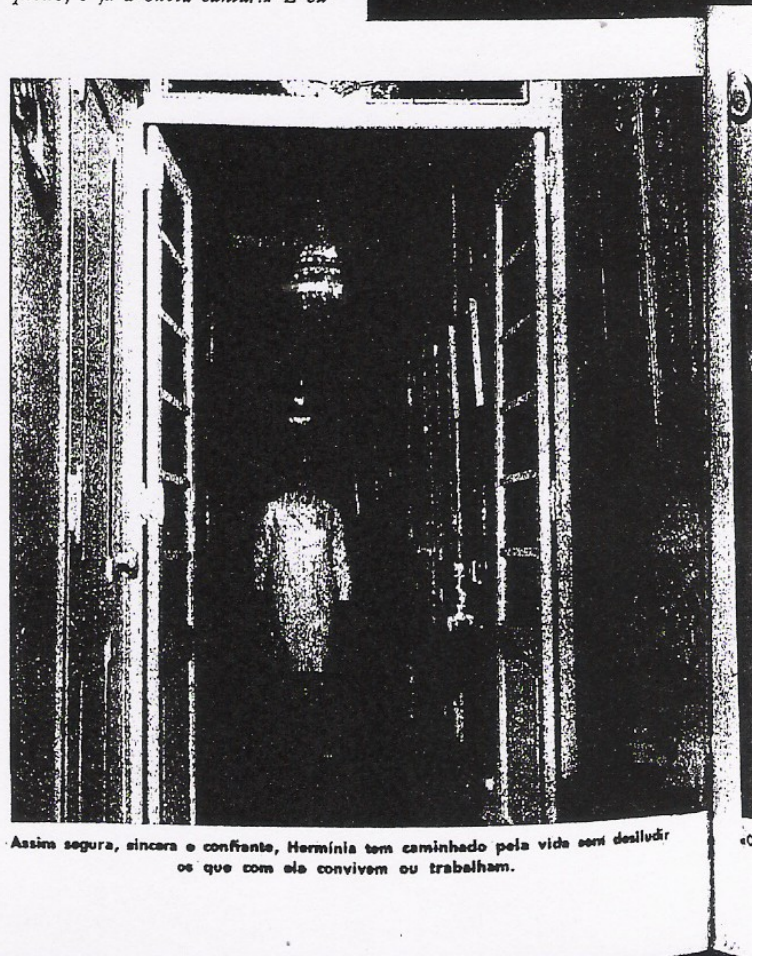



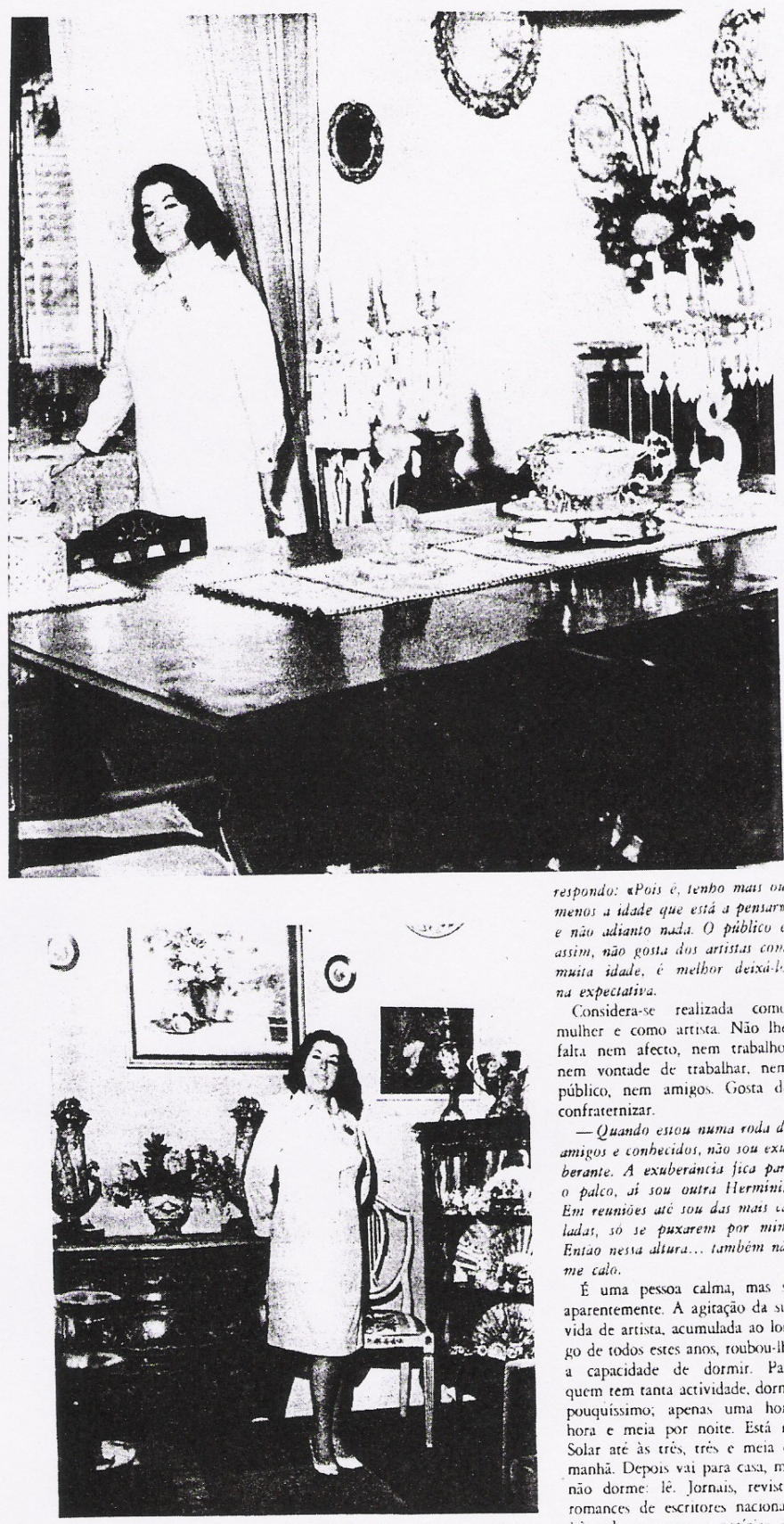

t t t a ?

Horminis Silvo gotsa do passer
em casa todo o tompo que th

- possivel.

Aapedias. Ate as seis, sete hords Acaba de adormecer de cansaço Guando pela jantla tentra jia a lua. do dia E em casia é a primeira. cvantar-se, mesmo antes das em pregadas - às oito e meia já esta na cozinha cosca muito de trabalhar em cass.

- Nato me cansa grandes per turbacies. Dores de cabbefat of olhos inchalos. uin certo cansugh O seno laz masiá fulfa. Mla qa bei-de fazer. Tomar comprimi dore laso nat atueru, tenbo med do hibita

Acha-se tima pessoa de sorte Quase desde que naseca you wrte a tem balejado, diz-now

Nasca no bespital de Saro

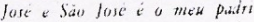
who. Sou muito religioss, sabte Imagine que tinha ens \& meses.

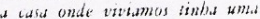
furtanda com grades largss. El er.2

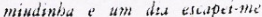
por entre as arudes nuth parar

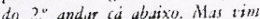
air no wlo de cise

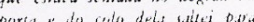

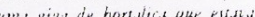

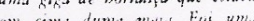

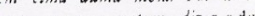
Me

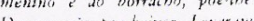

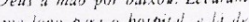

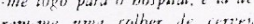

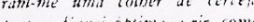

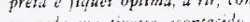

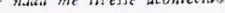
E e por ter tho sorte e saude que quer continuar a trabalhar, continuara anda per muites ano. nas suas casis tipicas, pelo meno, ja que o teatro so pode fazer de ve $\mathrm{cm}$ cuando. Gosta de actuar na Tie levisio Nio tem a contacto dire 10 do publiso que muito aprech amas é una quesio de híbir Nas primeiras yezes escranhames

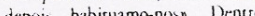
de apuns mes vai provar onero de a dixo, sa com ladon, a d dor

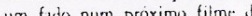
am rate

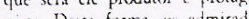

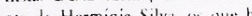
ros de Hermina Silon, or que bu muto tempo ná a vem, veran oportunicade de vela entio no celulúice, ainda que por pouc tempo

Dcixámos Herminiz Silva No a Solar da Herminias onde con versámos, delxamo-la do convirs do publico que esperava para ouvir. Connoxo veio a imagen da gatorinha que via ctudo lindo tudo a brilhas, e ta no meio voladora afirmaçán da fadist "Tudo guanto sonbei ie passous 


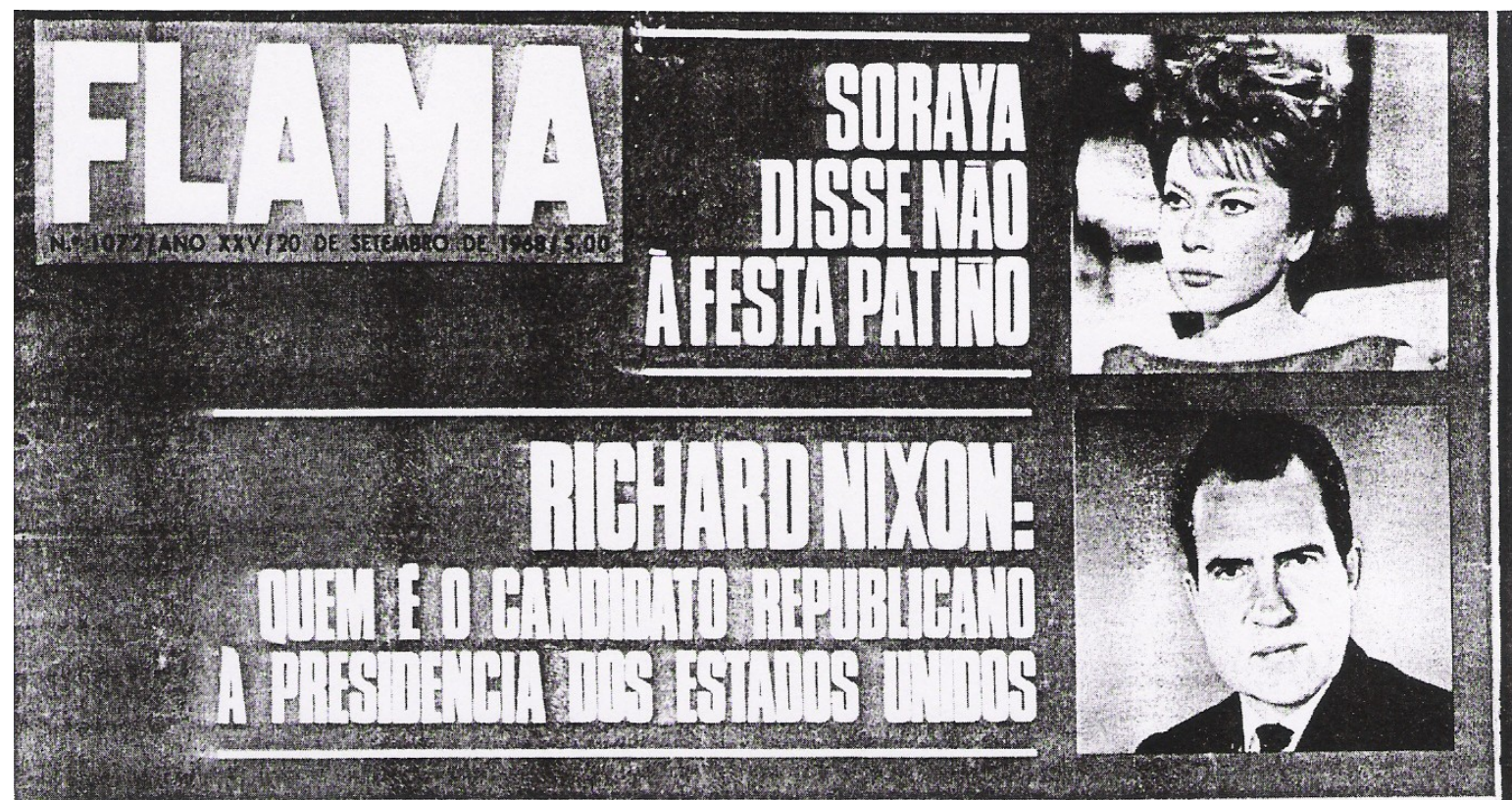

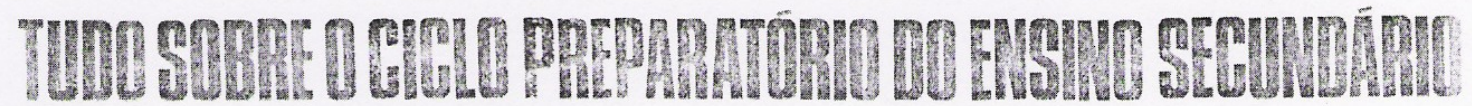

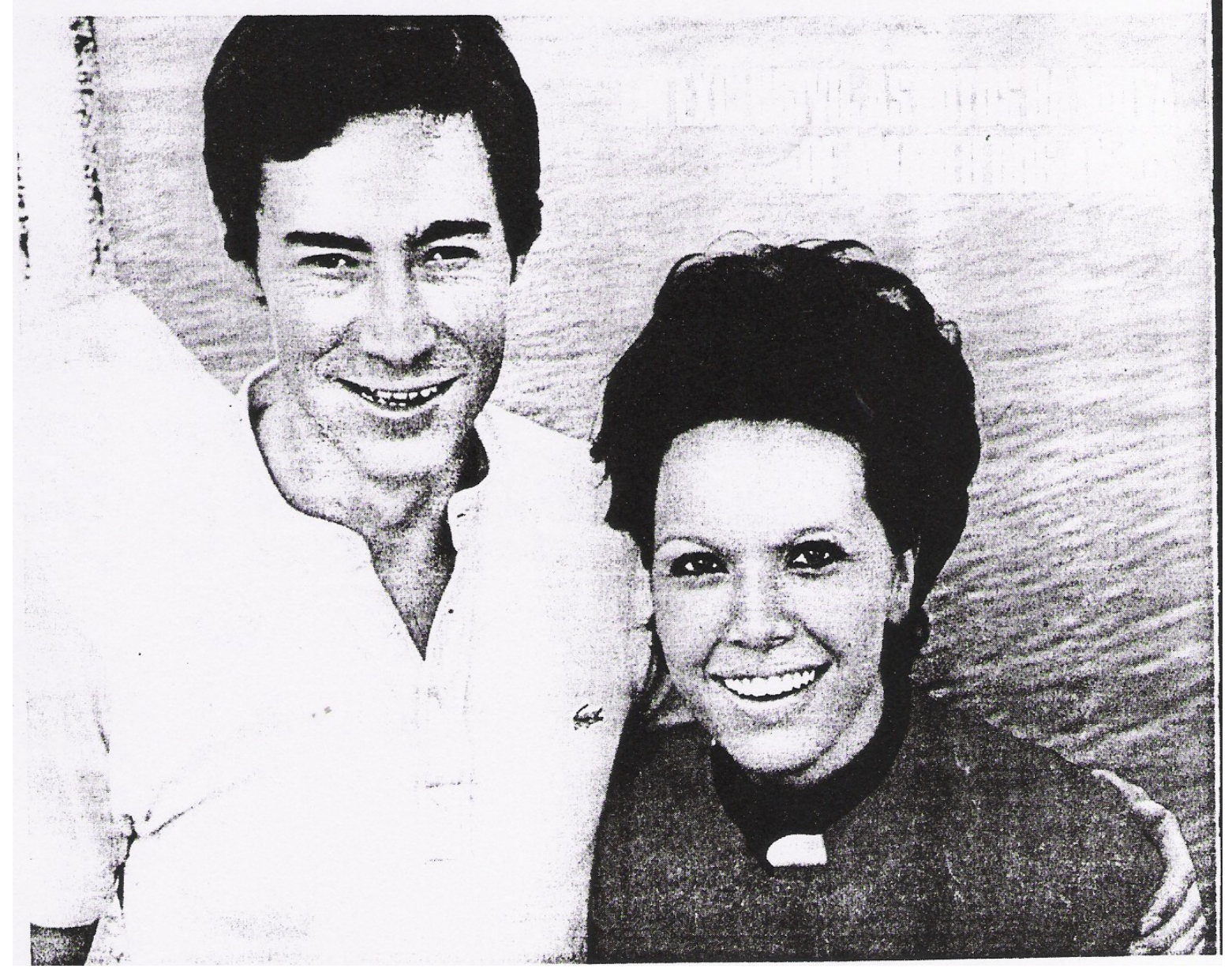




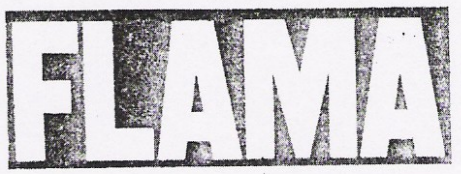

REVISTA SEMANAL DE ACIUALIDAOES

DIRECTOR: ANTONIO DOS REIS

ANO $\times X V \cdot N \cdot 1072$ - 20 DE SETEMBRODE 1968 PREC $5 \$ 00$

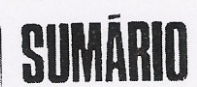

ESPECIAL

- Everes con ane 40.43

EXCLUSIVO

* Ricrate Nxen esta dearente? 44.47

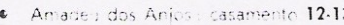

- Soráa 20.21

ACTUALIDADE

a En ....................

REPORTAGEM

- Festa la Zorbija

- Cice nimpatone

- Autcr cueis anonesaj

- Hospederas de Portuga

- Liston mocerria Oivais

-............................. 34.35

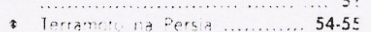

AMADEU dOS ANJOS E A NOIVA

DESPORTO

- Is sube tucoues no witetol ...32.33 CRONICAS

- cren

- $\cos$ ros

RUBRICAS

- Tema naciona

- Cartis ac Diertor

- Grtis as Drertor ..........

Vegocius a whiridat

- Trugrama:

- iroces

- iseos

- Dajovera...........

DA MULHER

- Acualuaces temninas 52.53

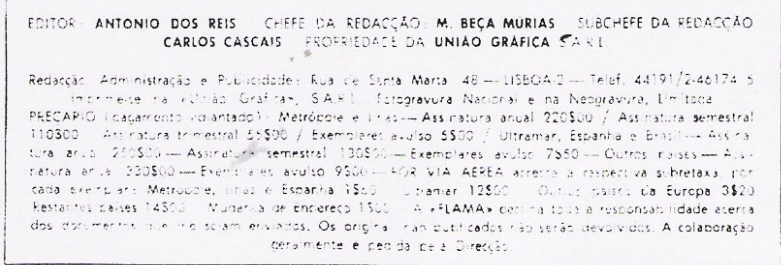

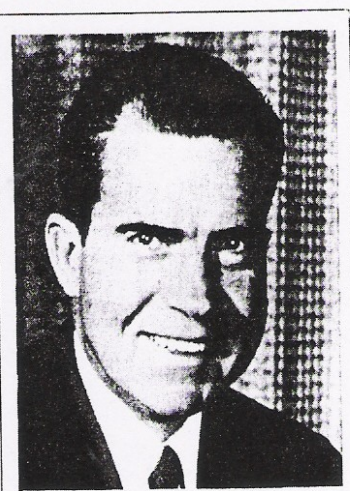

ELEICCOES - Aproximam.se as eleicóes americanas, facto que, náo so ao nivel nacional como internacional, se reveste de uma importancia dificilmente zlcancável por qualquer ouiro acto desta natureza. No sentido de proporcionar aos seus leitores uma informaso ta completa como aconte. cimento merece, "FLAMAn comesa cimento merece, a tflamas começ, a publicar, no presente número, uma serie de artigos sobre os personagens mais em foco no momento politico de i lem-Atlántico. Assim, e na semana em que, no estado de Nova lorque iniciou a sua campanha o candidato republicano, apresentamos, pela pana autorizada de Livio Caputo um perfil de Richird Nixon, para que chamamos a atencio dos nossos leitores.

A vez de $H$. 4 Humphrey chegara na proxima cemaria. 


\section{AMADEU DOS ANJOS morado», dizla Juan Belmonte. E o sentumento e a paixá É este o caso concreto do toureiro Amadeu dos Anjos. \\ REPORTAGEM MANUEL VIEIRA

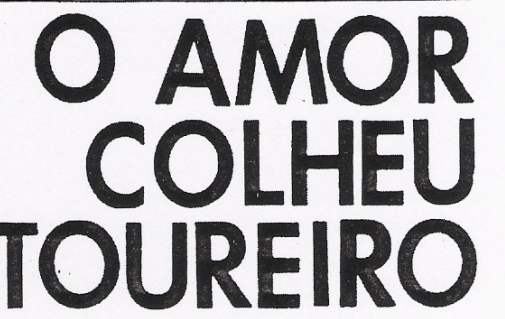

hamei-lhe um dia tou-
reiro cara-de-menian reire cara-de-menian renta tä́ bem a pete homen. sensivel no trato. meninciro nus brincadeiras. cat raio na $\mathrm{ex}$ pressäo, no sorrir e no rost mal barbalo. Kijo como aço. olhar miadinho, penetrante de quem salic o que quer, e amigo como poucos naten ser. be. testa adulacipes e cumprime log que tilicilmente retribu ria. Gosta te amıgos, precisa deles e sabe nnde ins encontrar. Nao as duzias, como lie seri fácil, lem os anigos que esco. gados que

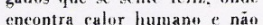
acenta falor humana e ná natismo oferee a sedetas, $E$ Amadeu de vedeta cio tem is arte de empunhar a umuletan. aquele reitigo cure o coloea entre os cornos de um foiro. una carseira escrita rom pxilos $\mathrm{P}$ ricatrizes.

NA CAPITAL SE MARÇANO

Safurdào í aldeia heirà. Lima da" muitas terreolas erguilas te visto. onde o lado a terra num exgotar monotono de dias e corpes. Sa. furdace ó a terra de Amadeu Augusto Anjos (que o dos w) aparercu mais tarile, a juntar. ee nos rarlazes. furmandon tomreiro). Amaded for agarrado ano livros inadrace. partill caluectas a vidros. Vhor. mal. pertanto. I màe. que era teredeira. via.se e desejava-se para sustenlar " rapaz. mais us ipuatro filhas que rumpleta. am a Camilia. Dan infancia humildes nail fira a hisloria.

Lishoa era outro horizonte. Na cidate podia fazer-se un homem. Profiscãu: marcano. que 'c a

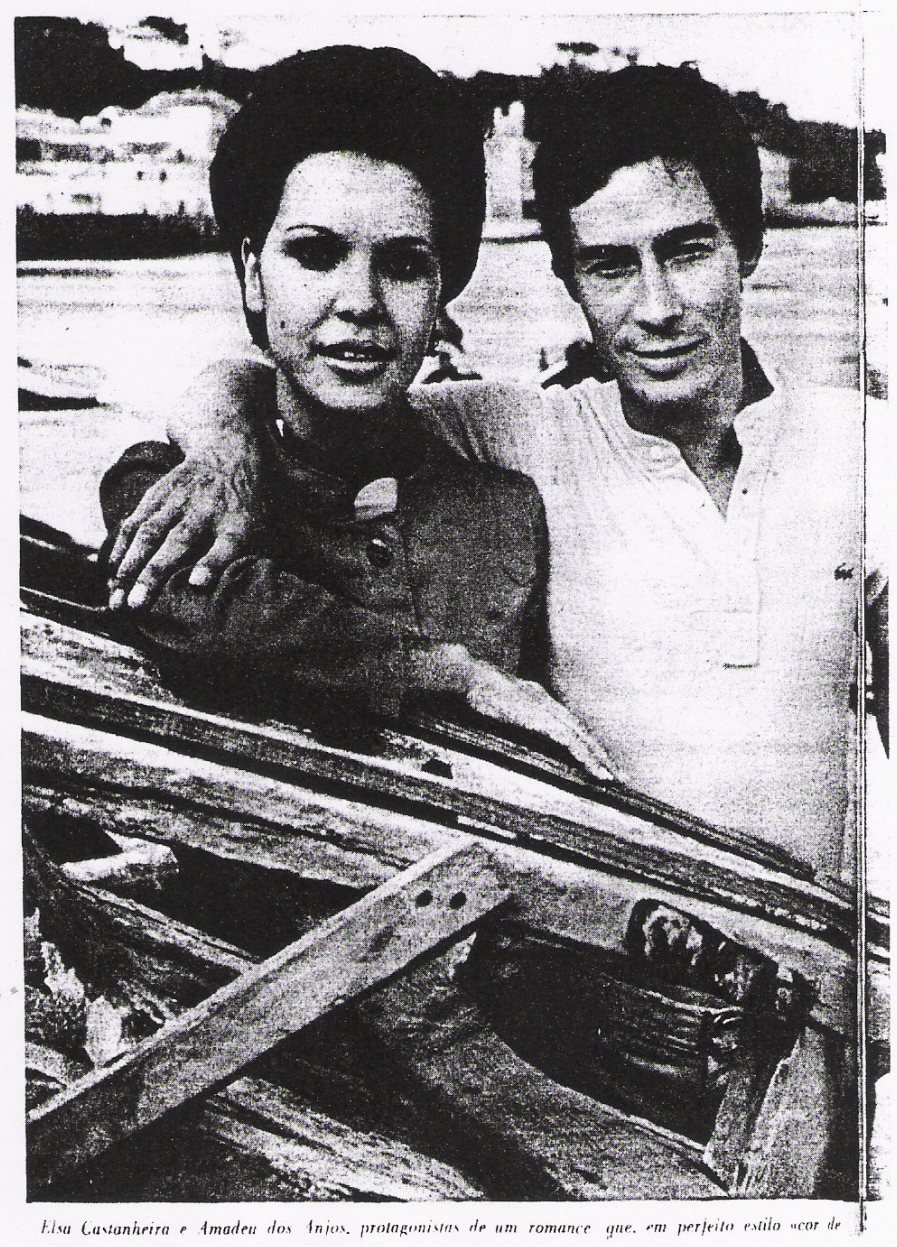



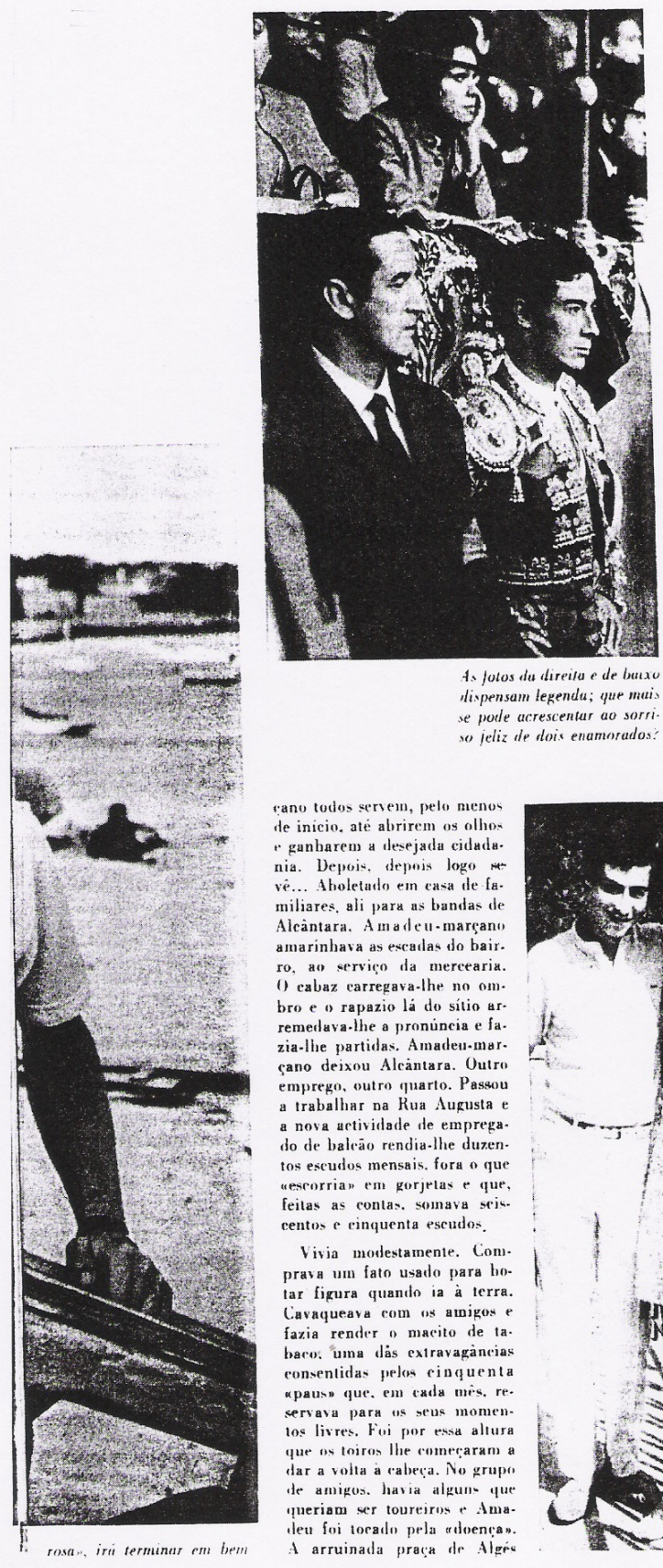

$O$ toiro circult nus conotes dos peries de brega. Na trincheira. junto do apoderado Fernando Camacho. " matalor esta atento. Na barreira. mesmo yor cina, a Eilsa esta presa da mesma atençàio. Noiva de tou reiro, ela já aprendeu a wern a qualetro, ela ja aprendeal a comportar dos toiro.

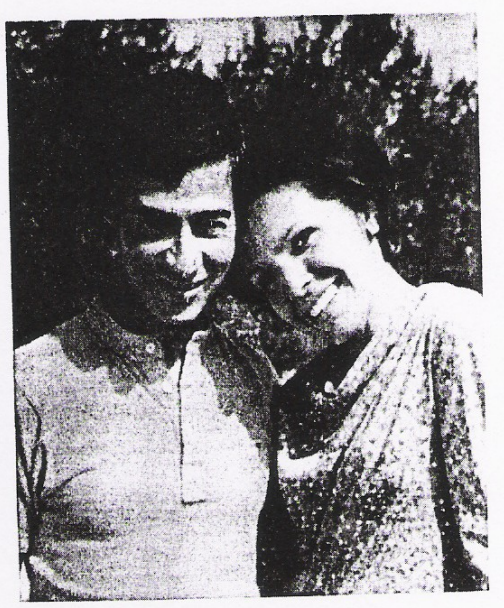

rano todos sersem, pelo menos de inicio, ate abrirem os olho ganharem a desejada cidada na. Depois, depois logo ... Aholetanto en casa de fa.

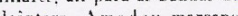
a . , ao kervico la mercearia. calbaz carregava-the no once remeluva-the a pronuncia $e$ faano

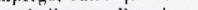
rendia-the duxen tos escudos mensais, fora o que eseorrian em gorjelas + que, centose $\mathrm{e}$ cinquenta escudos.

Vivia modestamente. Com. prava um fato usacto para bo. lar figura quanto ia a terra. Cavaqueava com as a anigos fazia render on maeito de taconsentidas pelos cincquenta cpausn que. em cada mes. re. servava para us seus momenlos livres. Fui por ensa altura que on toiros lhe rnmeraram a har a volta a rabeca. No grapo de amigos. havia alguns que queriam ser toureirse chara-

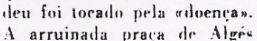
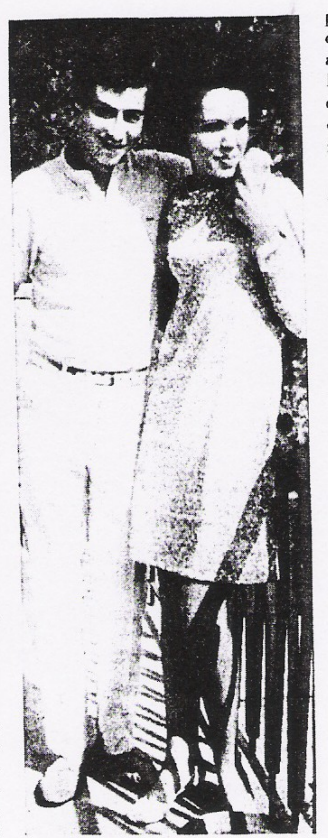

Bassou a ser a chonumentulv dos seus sonhos. a praça onde assistiu as primeiras curridas. Depois. foi um crescente de entusiasmo, ingresso na escolo eem que ele tinha jeito.

BONDOSA, HONESTA, DONA DE CASA,

Ciesta do Sol a uercedes. de Amarien rolaya, mansumea. e. sem destino. Falávamos, an mas ers fatal. toureiro enamoralo deu a conversa o rumo ujue the inte. ressava..

E tuclo tä diferente..

Tanto disparate que jaTanto disparate que fazemos. F. a primeira vez qua gesto dle ama mulher. lenho a cerleza. E a primeira ríz que neressito da sala presença rons. tante. que corio para ses ladio... Isto e a pelicitarie! A tisa extruordinaria. tem chase. sobriedawe botro ser simples coma ela gosto.

Yáo imaginas camb gke. a encarar a vela. 1 ma alma nova, uma nor'a rontale. força sem limite.

SEGUE 


\section{AMADEU ANJOS}

\author{
e Bondesa hunesta. dona de \\ casa", isto dizia Amadeu do \\ Anjo: a reportagem do ali \\ man (cumprem-sc. precisa. \\ evideal feminino Itoje Am \\ len relentra a areerenta \\ - E Joi isso que encontro \\ 4 Elsa reune tudo isso. \\ Como a conbecen? \\ Em rasa de uns amigos. \\ Primpirn em ronlactoss crrimo- \\ me preconterulo comersám \\ mais a compure arsim nè p" \\ A.... \\ A Elsa (Gtero Castanheira) \\ tem 20 anos do idade. Em \\ Yovembro, més provavel do \\ Come somara os 21 . \\ che \\ mace the adoca

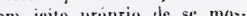 \\ en jerto proprin in a \\ lactual \\ actual. uma ra pa

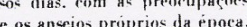 \\ Cas anseios proprios da epoca. \\ as pas para as bandas do \\ ins pais. para as bandas die \\ Lamiar Tem um passate mp \\ pre \\ coracăon. Fin a "lisinlata que \\ decorou a crasa. consceguindo \\ surpreendente resultadio. Gosta \\ de criancas e de horos (solu- \\ firmezis id erarácter. \\ queer predicalo duma ado. \\ quecer predicalo duma adto \\ lescencia nán distante). No \\ mela quarta. ingar de destaver.

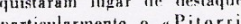 \\ nhom, ofesta to Amadeu. \\ SALAMANCA - TERRA
} ADOPTIVA

Foi um novilheiro brilhan te. Conquistou troféus. Eir uma esperancia da tauromaquia lusa, dizia-se. Uma experanca que sentiu o fracrsen. Sem mo ral. $\mathrm{sem}$ dinheiro. de esperan cas perdidas, mala aviada Amadeu voltou à terra. F foi na Guarda, quando ja pensav na Guatranja (Alemanla ou Francal guando tudo indieava Tue seria mas une reuiprante a precurar noutra tarefas

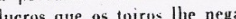
lacro que che corme A a a festival oraniza. do por Adolfo Aparicio e Joa

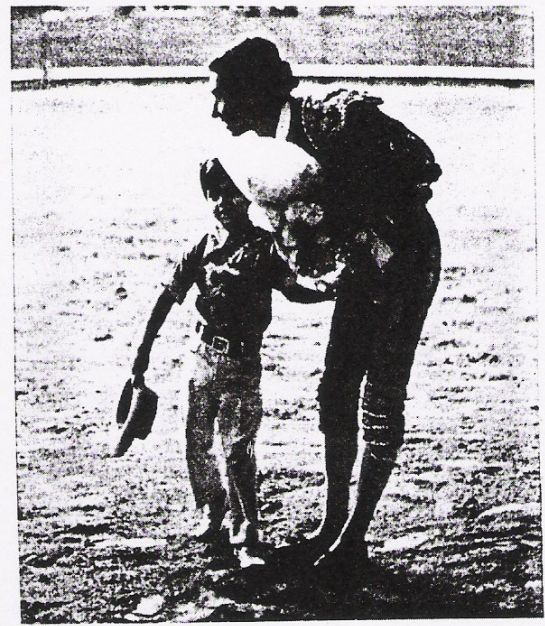

poleose no Campo Pequeno finta a cornta nm pequemina udmiralor oferece a Amadea tos finios um ramo de flores.

quim Caminn e ambos o ron. indaram a arompanha-Ins ate alamanea. Partiu. Tarimbu pelos wentaderos" da regian. ndou pelas novilhadas eron micas. onde os toiron näo veren picater. foi collindo. corre praças le "pueblos" ede corda. des $c$. finalmente. a ilo de Juho de 1962 . ahriram-se.llie an portas da "Mlonumentaln de Madrid. No fim da corrida. " coureirnesara-de-menimo, triumfante. deixou a praça ostentan. do as duas orchlhas que acalara ie cortar.

Por Salamanca ficou. Era Espanha e na. de Safuridáo. Todos os conhe. cram. Tordos sahiam que " ma. tador portugues tinha um apar. tumrnto no Passert CanelejaGanhou a s mizade $p$ o respeiti dos "aficionados", ganhou lu. gar a mesa dos ricos "ganadi. rosm. honras de figura no difiei e ardilose mundo taurino. $\mathrm{Ti}$. nha valido a pena. Salamane foi a terra da sua alternativ flendo Pace Camino por pa. drinho e "Bll Corrobesn com testemunha). Salamanca adoptou-o. fi-Jo renaserer toureiro. deu-llie a confiança táo nere: saria a profissáo que escolhera.

ENFERMARIA - a OUTRA SAIDA EM OMBROS

Nào se salve como aquilo acontere. Mas. de repente. "pilons encontra uma perna la vai o toureiro aembarcado nas hastes do toiro. Km Espa nha há cornadas, aloumas be celas. que trazem sabor a mor te. Por ca o corte do "pilon: atenua o perigo mas nao o el mina. que tamliem se morre na arenta. $k$ náo se salse aquilo acontece. Basta um gundo. perdesese as "raran loiri) e zas. (I) malandro aprel. de num instante. toire e bicl abide. e luladar que tem seus "golpesw.

Figueira da Foz. l'raça bo nila " "fapnan a sair na per. feiçăan. Modelar como as qu na presente lemporada. Oun apuro de forma, Amadeu do Anjos tem desenhado. F, na * salse como aquito aron ceu. Primeiro no ar. depmin chäo. o "esparda" sabe que por cima dele lia una mentanhia de c:arne a" uma paliegurra. hem armada. a abaterse sobre seu corpo indelesio. Cabre a nura. defende-se como pode pensa ems Deus, 6u $\mathrm{cm}$ cois nenluuma $p$ fica à espera de quem o va safar daquela situa. cáo incomoda. Náo e por acaso que os toureiros fonhece

Amadeu rolow na terra pro urando fugir ao inimigo. D confusão de pratas e chifres sai meio-consciente, rosto ensanguentado, expresán de sofri. mento. Em ombirns recollecu enfermaria da praşa. Vejo.o hegar. Mal respira. dos labio caem-Jhe monossilatus que sä a dar materializada. Lla un medico resmungan e um eniermeirn com ucralon. 0 médic toma o pulso do toureiro grita. Há meia dúzia de row(i.) sombrins, desconthere-se a gravidar. Entra um ocamara-man " que filnava a corrita. Entä. Amadeu:... I panhou tudo?": tpanhei. como sai isso? Ombe is que rosé pstava a filmar que nâo " vi."

Aos circunstantes espenta is calma do matador. Mas elesăl assim. rijo comono aço. so deste modo podem voltar ao redondeis $e$ a manler contacto rom huspitai $r$ clinicas.

Mais tarile veiu a radiogra. fia e" " diagnostico: luxacion ortida (claro) o mais isto aquilo. a juntar a fissura cootela nán sej quanio. Coisa para 211 dias, dizeme os que ja passaram por iqual transe. Aa quele dia. para Amiateu tha Anjos. म corrita acalou tor cerlo. Depnis $\dot{e}$ o vai e $\mathrm{rem}$ doamigos e adtuiradores. "C.mon esta ele?n. at coisa grave? "Muito Lempo?". "Ainda ben. coitadom.

UM TOUREIRO PARA MARIDO Conheçu-c há um hom pas de anos. Vi-o sair em ombro pela "porta lasgan. Vi-o derro. tado. Irste aprós uma actumes desajeitada. 1 c camposm a de. saparecerem do rompanos il aceso pue algum. julgara antever. Amadeu de hraço par. lido. engessado. ders meses lonpe dos tairos. corridas can celatias e varias rentenas do

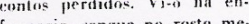
Cermaria, sangue no rosto me morado.

E. outra vez dia de corrida. A Bisa esta na harreira da Mraça. Ca en haiso. meme pre

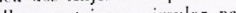
be Vila "Elsinlat pesta atenta. ja apren. deti a char wäa alery nepeili e admiraça. a dern ne-

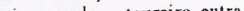
pois. quando o thurriro enta a vio rii as unlase de. a jalenta. mol as unhas e de. peja tue tho aquilo acabe de pressa. Sc A jovem nasce una nos labios da jovem nasce uma prece as mas jus fortalecer a oraça. Bla apren.

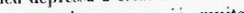
un tnureiro. encara ja. muito rompenetrada, "sen an de milher dle Anadeu dos An jo.s. enmpanheira para os bon e riscon tido de oiro. para matar ou morrer. 


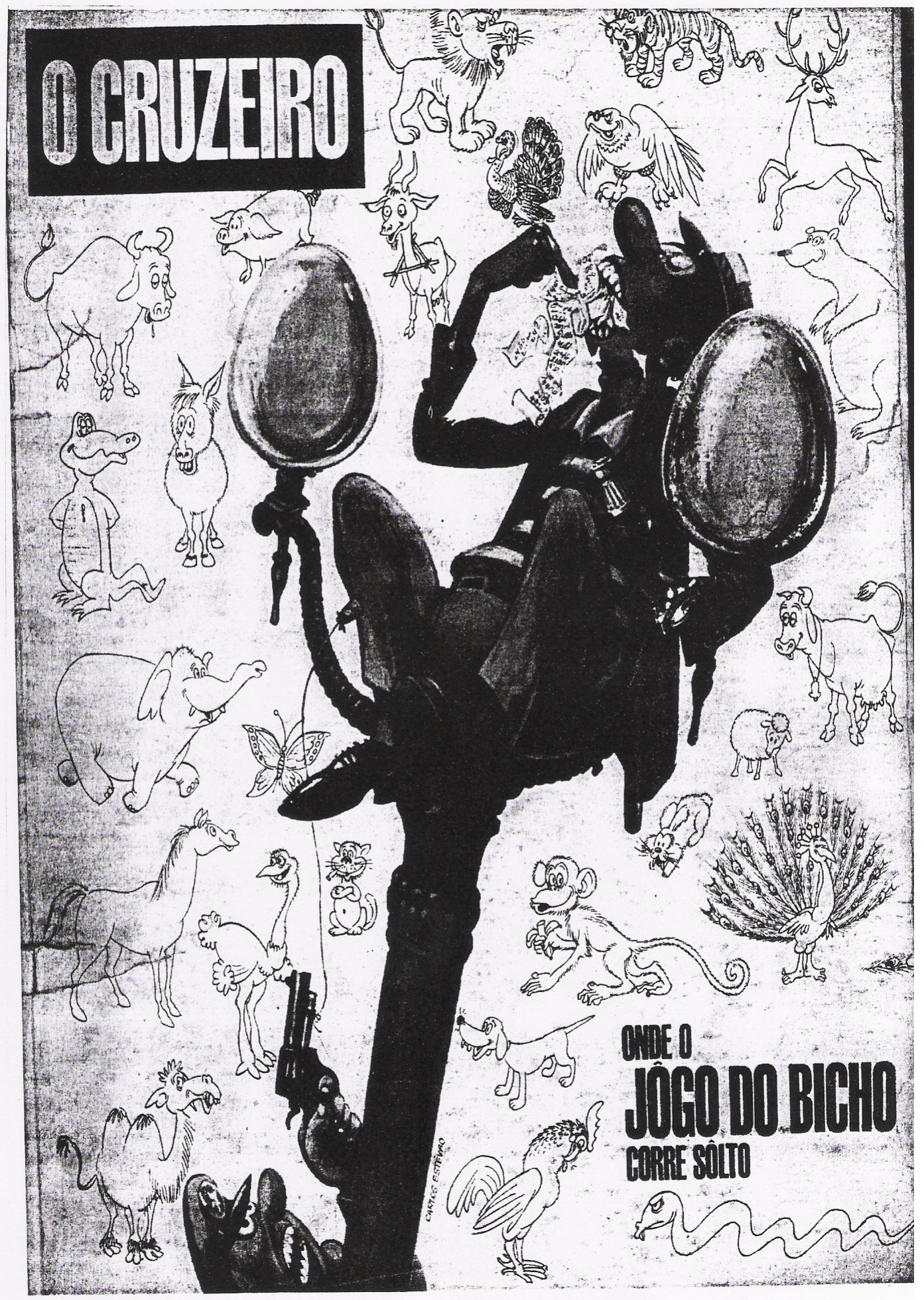



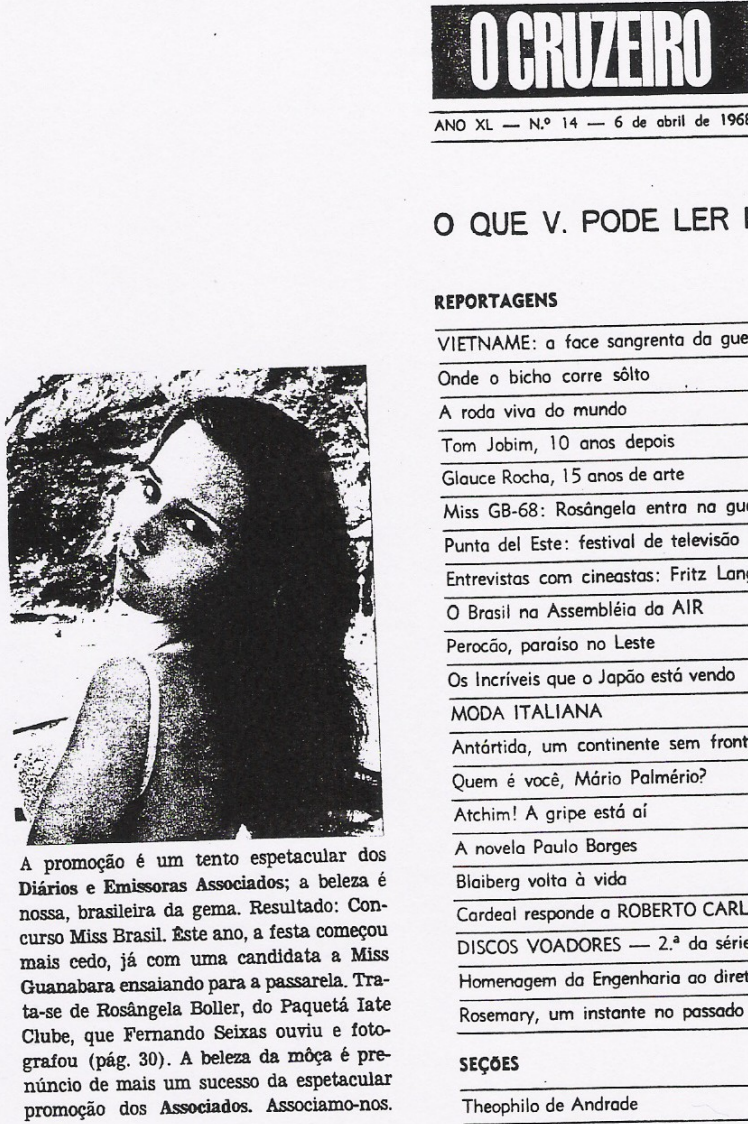

ANO XL $-\mathrm{N} 0^{\circ} 14-6$ de abril de 1968

\section{O QUE V. PODE LER NESTE NÚMERO}

REPORTAGENS

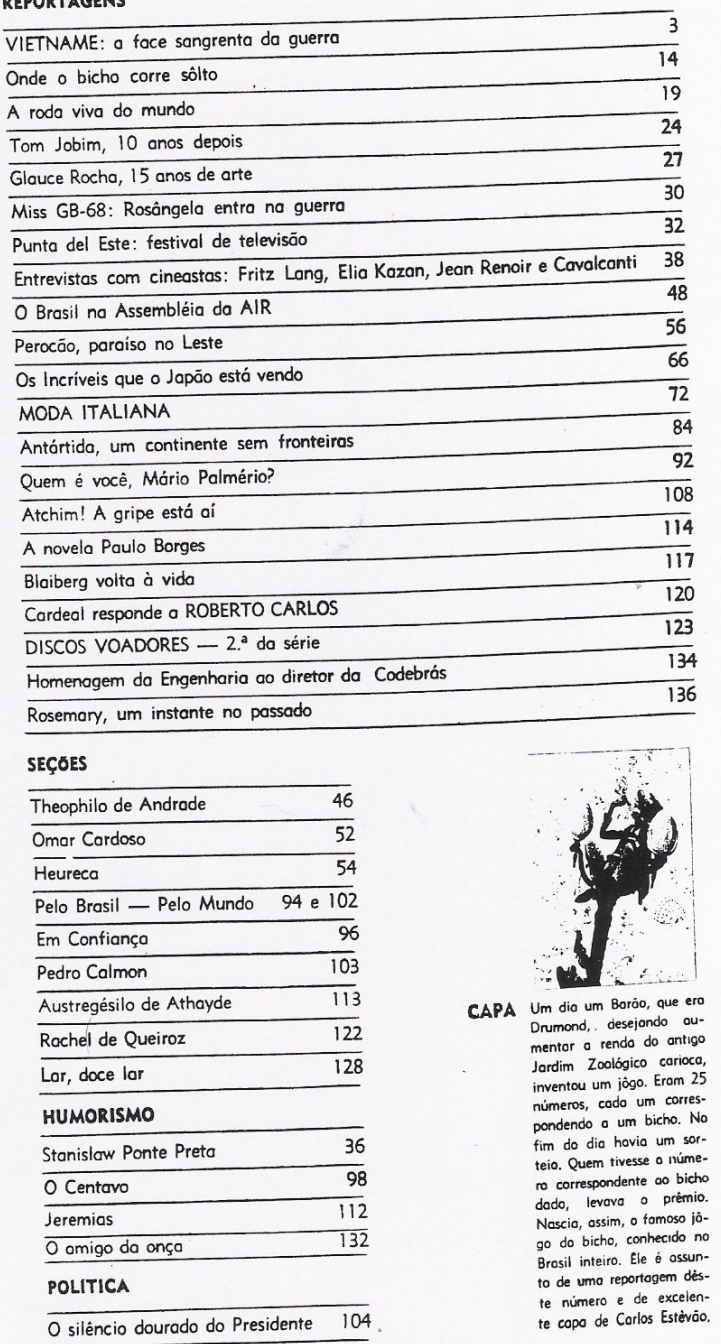




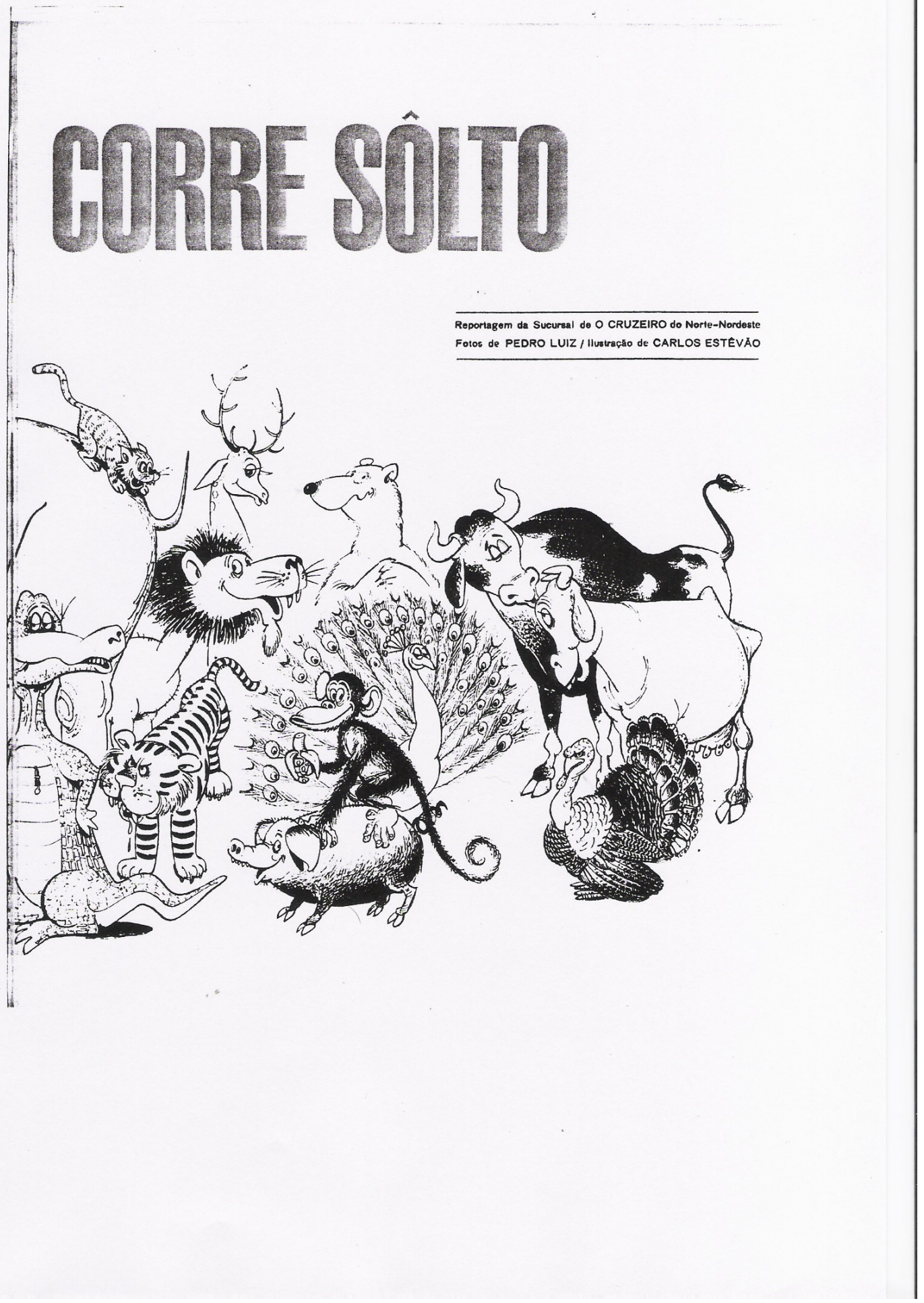




\section{RECIFE

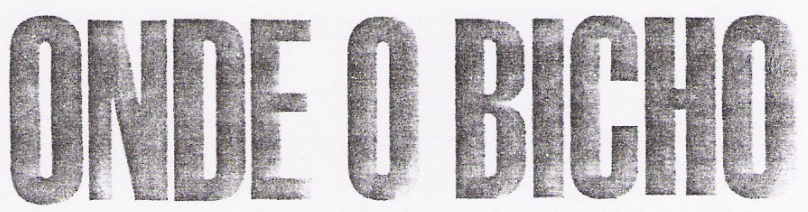

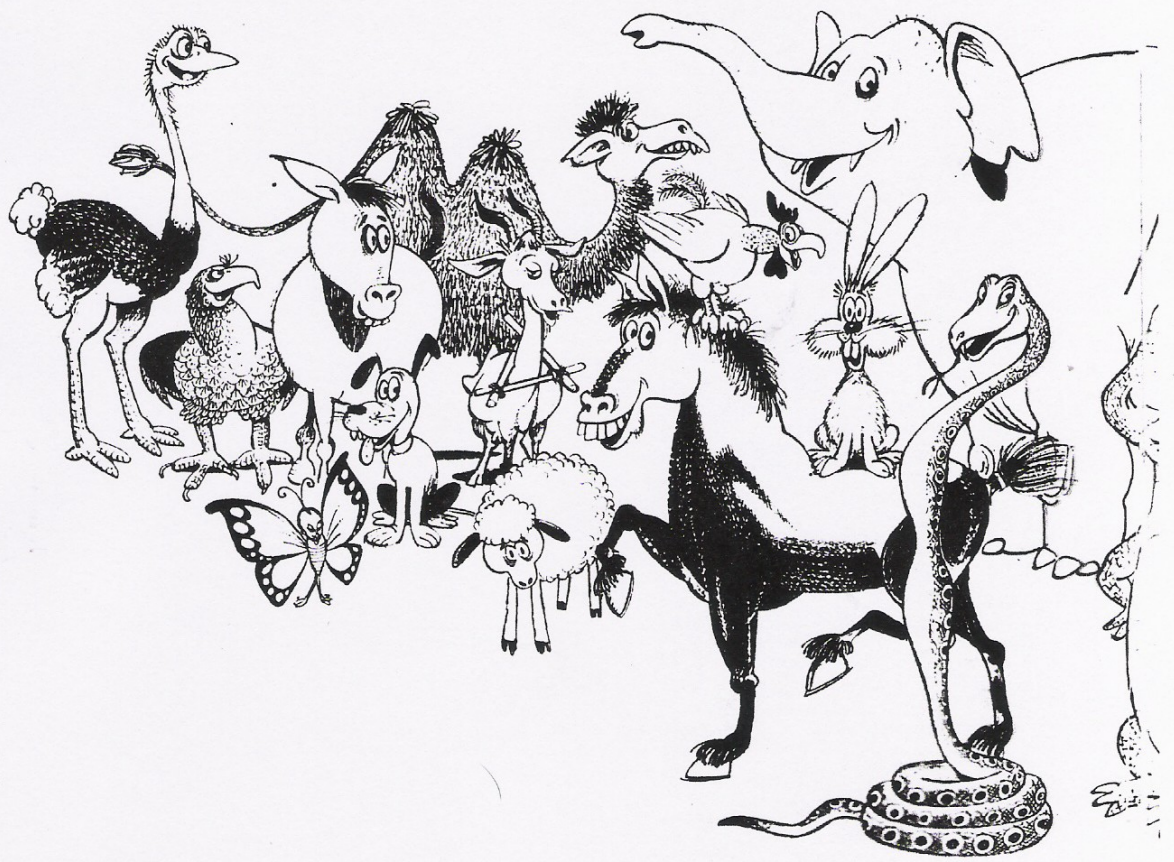


Quem mora no Recife sabe. () jôgo de bicho. la. ¿ livre. Funcionı

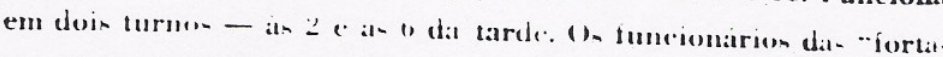

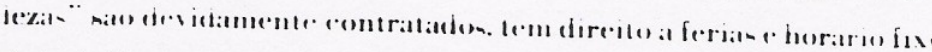

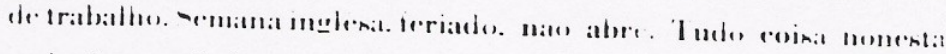

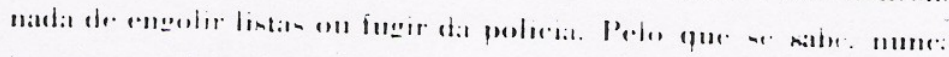

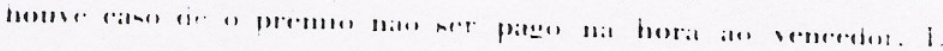

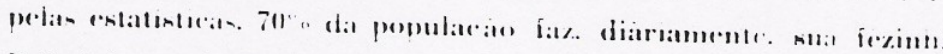

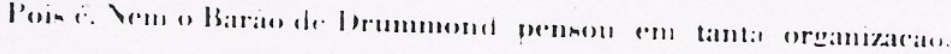

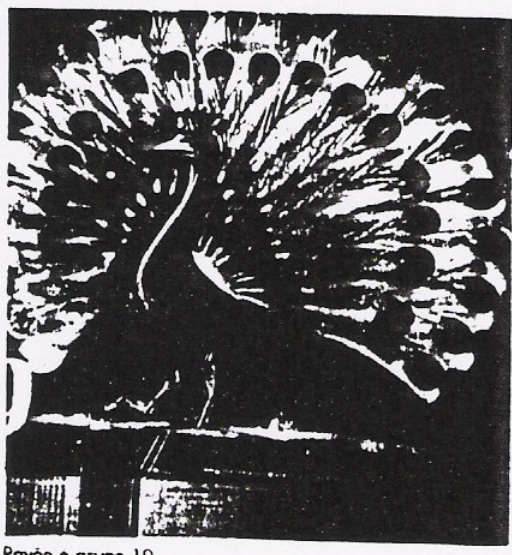

Povóo grupo 19

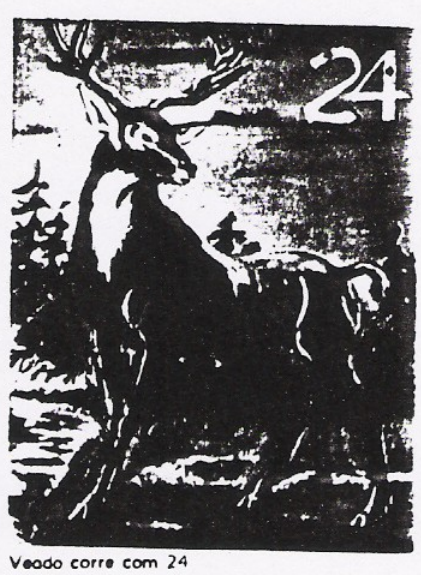

veodo corre com 24

público a partir das nove horan da manhá. Menor de lo in nuo jógo de bicho no kecife ato abertan ac

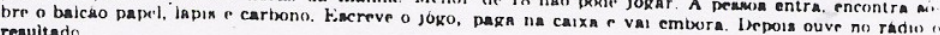

$\lambda$ búch pequena corre qü. o geverno do Eatado e conivente com o jógo. 1)izem - ninguem afirm.

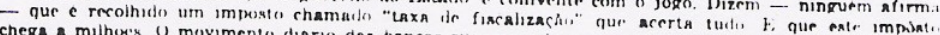
cipaimente nox tina-ieresernanas. Ciada cruzciro nove aplicado

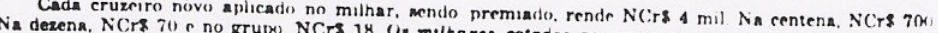

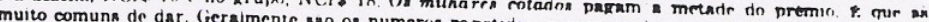

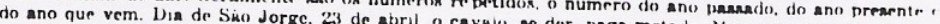
ail, que bicheiro nio o boto.

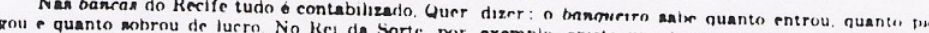

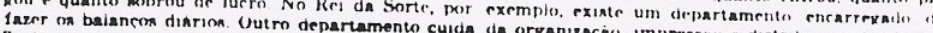
I ucio gente exprecializada no ansunto)

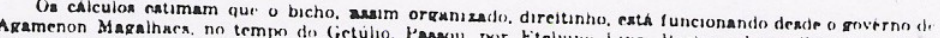

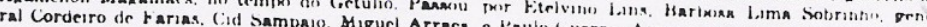

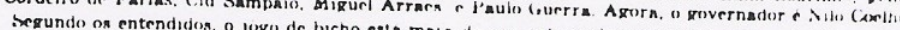

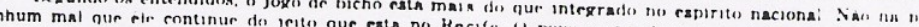

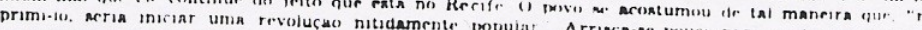
o pernamuucano gonia dias

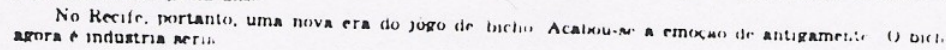




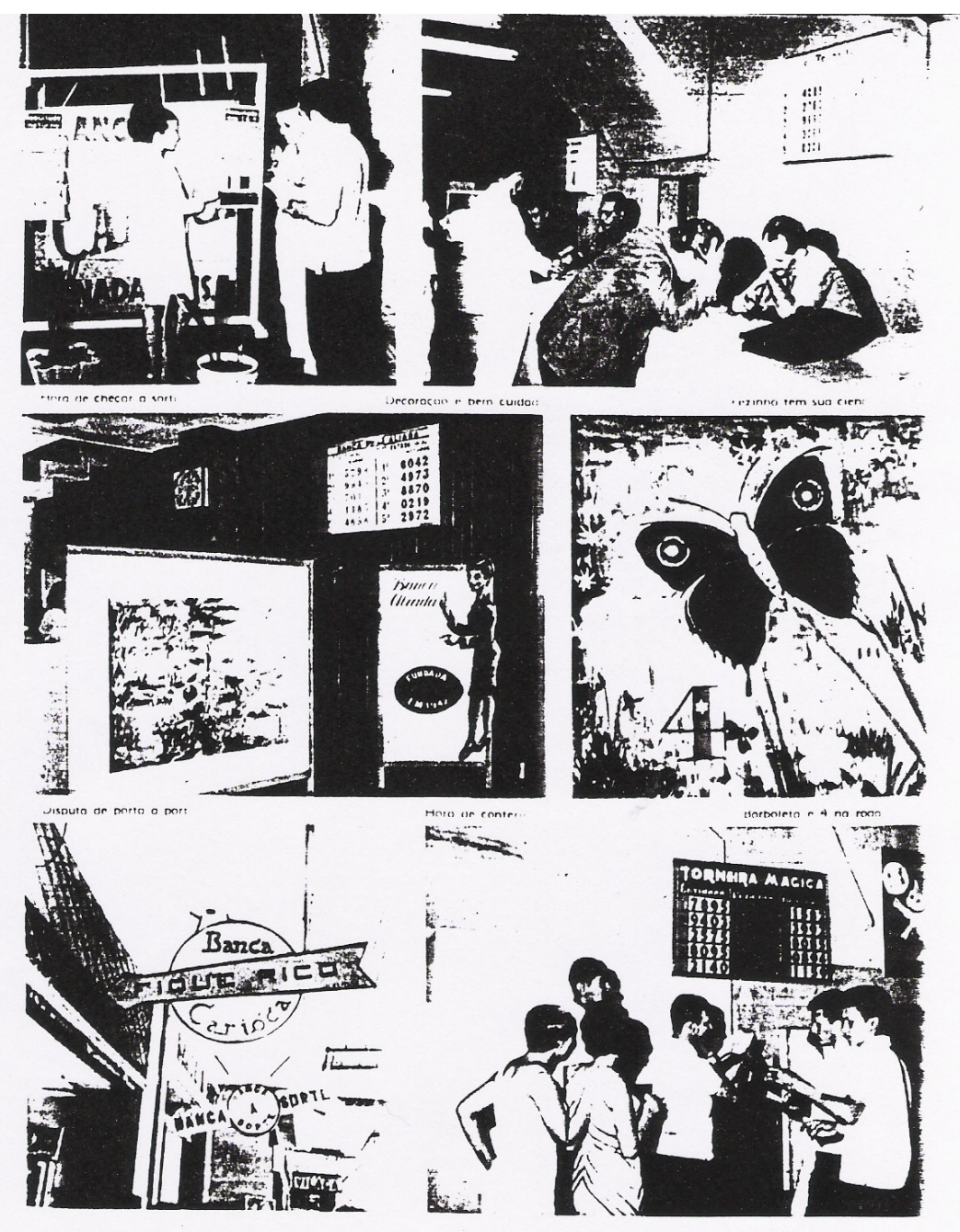




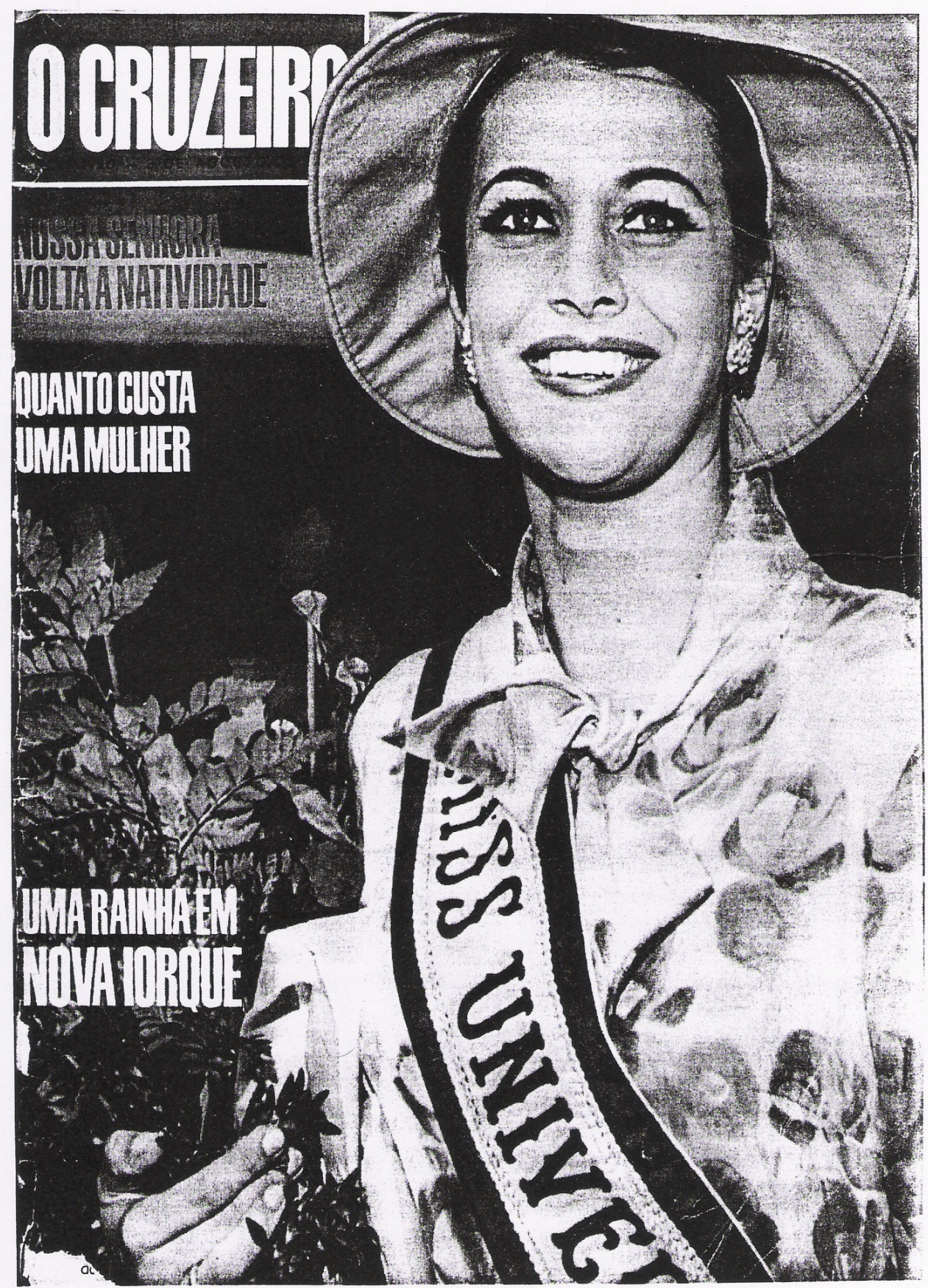


Há um ano alrás Gutemberg Guarabira era um ilustre desconhecido que morava em Cachambi não tinha telefone e gostava de freqüentar o Clube de Jazz e Bossa, na Casa Grande. Frequientou, fre. qüentou, féz lá umas amizades, entrou num grupo e passou a ser cantor. Foi quando baixou na noseo Gutemberg a inspiração de compositor. Compôs, entâo. Apareceu um Festival, êle entrou, foi clas. sificado, quando vin tinha tirado o primeiro lugar. Foi uma badalaçäo geral: dêle, da música, do Gru po, de Cachambi, de todo nundo. Também, quan do sumiu, foi um sumiço geral: dèle, da música,

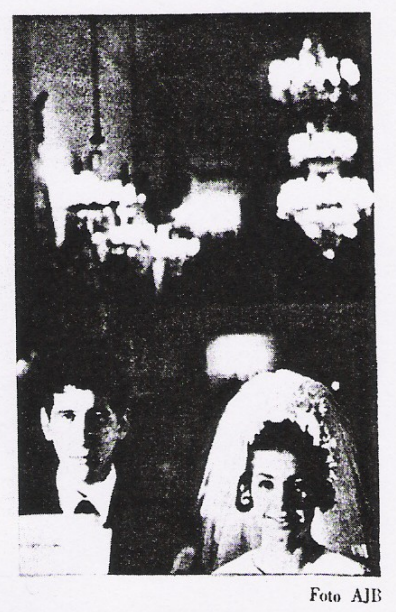

do Grupo, até do Cachambi, que nunca mais ouviu falar. 0 nosso Gutemberg não compós mai nada, quando todos esperavam um nóvo composi tor na praça. Ele tentou explicar que tinha sido comnositor assim, sem querer, estava ar rependido, mas a mprensa, sabe como é (afinal, êle tinha o nome do inventur da coisa), continuou badalando,
cobrando com simpatia. Mas não deu. Daquela toca não saiu mais nenhum coelho.

Agora, Gutemberg casou. Se ninguém ouvia falar nèle é porque ểe estava namoranito. Guaira, sua mulher. é filha do presidente do Banco do Brasil, sr. Nestor Jost. Para o casamento éle convidou um mundo de gente, da crista da onda, mas o negocio furou: o ministro da Educaçăo nāo foì; Vla. dimir Palmeira tanhéén nāo. Foram us anigos, os conhecidos c o ministro dos Transportes.

$\mathrm{Na}$ mesma noite Gutemberg seguíu para Brasilia, em lua-de-mel. Quando voltar, vai procurar um lugar para morar. Já andou pedindo ans amigos para ver se acham um apartamentinho bom barato, em Ipanema, mas quem achs um aparta. mentinho bon e barato en Ipanema não diz nada pra ninguem, é claro: muda na hera.

Assim vai. Casou. Está casado. Será feliz. No próximo Festival, talvez classifique uma outra margarida. Casamento feliz é assim, dá sorte. STRIITFIRO 2-R-10KR

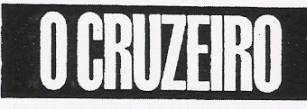

ANO XL - N. $31-3$ de ogósto de 1968

FUNDADOR DOS DIARIOS ASSOCIADOS: ASSIS CHATEAUBRIAND

O QUE VOCE PODE LER NESTE NÚMERO

\section{REPORTAGENS}

\begin{tabular}{|c|c|}
\hline MARTA: umo rainho em Novo lorque & 3 \\
\hline Entrevisto (exclusivol com o noivo de Marta & T0 \\
\hline Quanto custa umo mulher & 12 \\
\hline Miss-U E família & 20 \\
\hline Mães (de duas Martos) falam das misses & 23 \\
\hline Em Säo Paulo o CCC atoca d̀ meia-noite & 24 \\
\hline A lgrejo na horo do decisāo & 28 \\
\hline Bonança e tempestade na Tchecoslováquia & 30 \\
\hline Agnaldo Rayol: umo histório de amor & 38 \\
\hline Onde está o cruzeiro nóvo & 40 \\
\hline Ziraldo: o que estó em tôdas & 42 \\
\hline Dalida, uma mulher sòzinha & 56 \\
\hline VIETNAME: o longo cominho da guerro & 60 \\
\hline Quem é vocé, JUSCELINO KUBITSCHEK? & 76 \\
\hline António Maria, uma novelo ò portuguésa & 78 \\
\hline 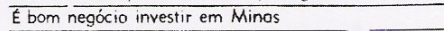 & 80 \\
\hline A NOVA MENSAGEM DE NOSSA SENHORA & 84 \\
\hline No Clássico, Remo venceu Paissandu & 93 \\
\hline CEAL eletrifica Alagoas & 94 \\
\hline FUTEBOL: Voleu a pena a excursão? & 99 \\
\hline Entrevisto (exclusiva) com o Dr. Lidio Toledo & 103 \\
\hline Entrevisto (exclusiva) com Admildo Chirol & 104 \\
\hline Entrevisto (exclusiva) com Tostão & 106 \\
\hline AGUA: um problema com soluçäo & 108 \\
\hline A natureza do espetáculo das catoratas do lguaçu & 116 \\
\hline A eletrónica faz o circo & 121 \\
\hline
\end{tabular}

A eletrónica faz o circo

\section{SEÇOES}

Omar Cardoso

Em Confionço

Theophilo de Androde

Pelo Brosil $\quad 58,75,82,50$

Lor, doce lar 72

Austregésilo de Athayde $\quad 92$

Conversa com o leitor $\quad 114$

\section{HUMORISMO}

0 impossivel ocontece

Jeremias, o bom

Stanislow Ponte Preta

Carlos Estévão

O Centaro

$O$ omigo da onça

\section{POLITICA}

Como a oposiçõo dialogorá com o govêrno

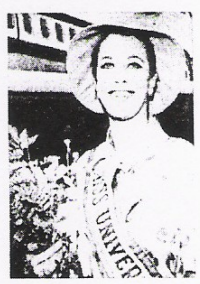

CAPA Marto é rainha, e nós os seus súditos. Por isso Indolecio estão em Nova loreue, ocomponhondo os seus possos, e Cloudio Kuck e Aldyr Tovares no Bahio, ouvindo seu noivo e seus familiares.
Todos juntos nos deram yórios repartocens. $E$ uma bela capa, em foto de Luiz Altredo. Paro aquêtes que têm fé, chamamos otençao paro $50 g \mathrm{em}$ de Nosso Serhora, com início na pógina 84 . 

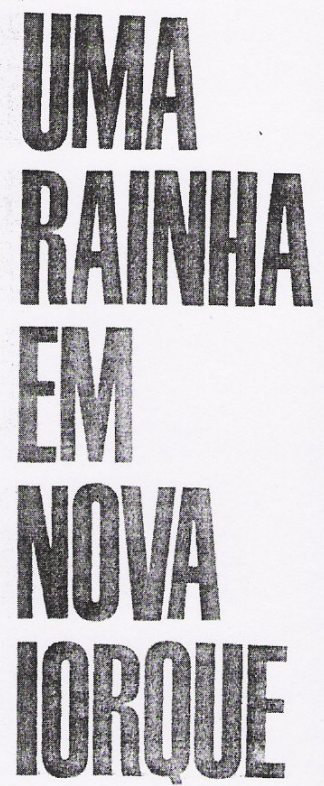

POr INDALECIO WANDERLEY E LUIZ ALFREDO

(erviados especiais) - Vis VARIG

Às 15,30 de quarto-feiro, dio

17, Marta Vasconcelos

chegou a Nova lorque. Foi

chegando e indo direto

pora a suite 3.834 do Hilton

Hotel, na Av. das Naçōes,

onde uma cabeleireira

uma manicure a esperayom.

O que Marta conhece de NI,

até agora, foi o que

conseguiu ver no trajeto do

aeroporto para 0

hotel, ou seja, a ponte sôbre

- Huison, que achou

"fantisstica". Mais nada.

Quando pensou que ia

dar uma volta pelo cidade

dia 18, mal conseguiu

andar por causo de uma.

inflamoçāo na unha do pé.

Teve que lancetar o dedo e

adiar o passeio. $O$ que elo

nõo póde adiar naquele dia

foi a entrevista coletiva

poro a imprensa, na sacoda do

Hilton, que durou mais de

duos horas e reuniu jornalistas

do mundo inteiro.

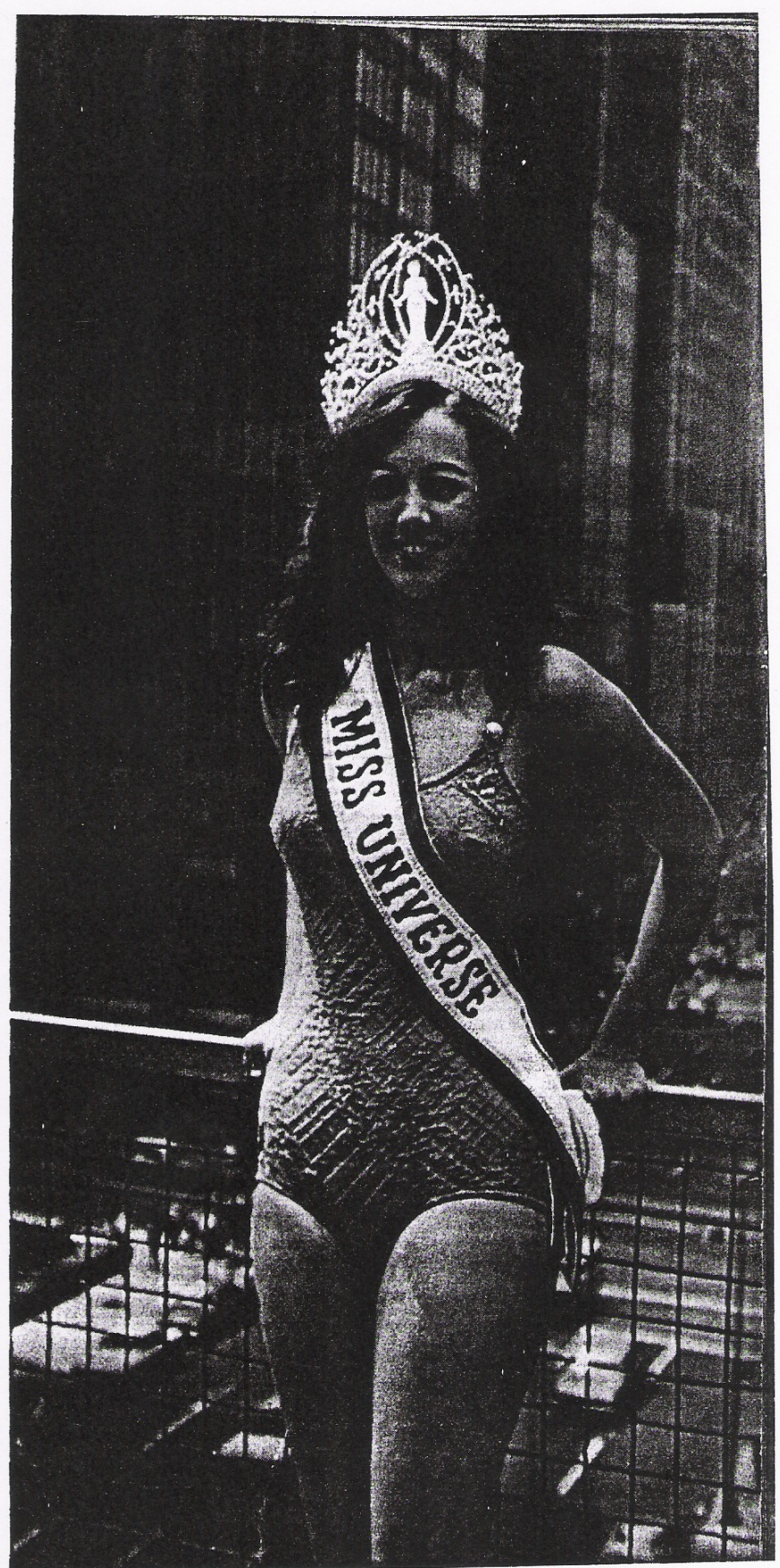




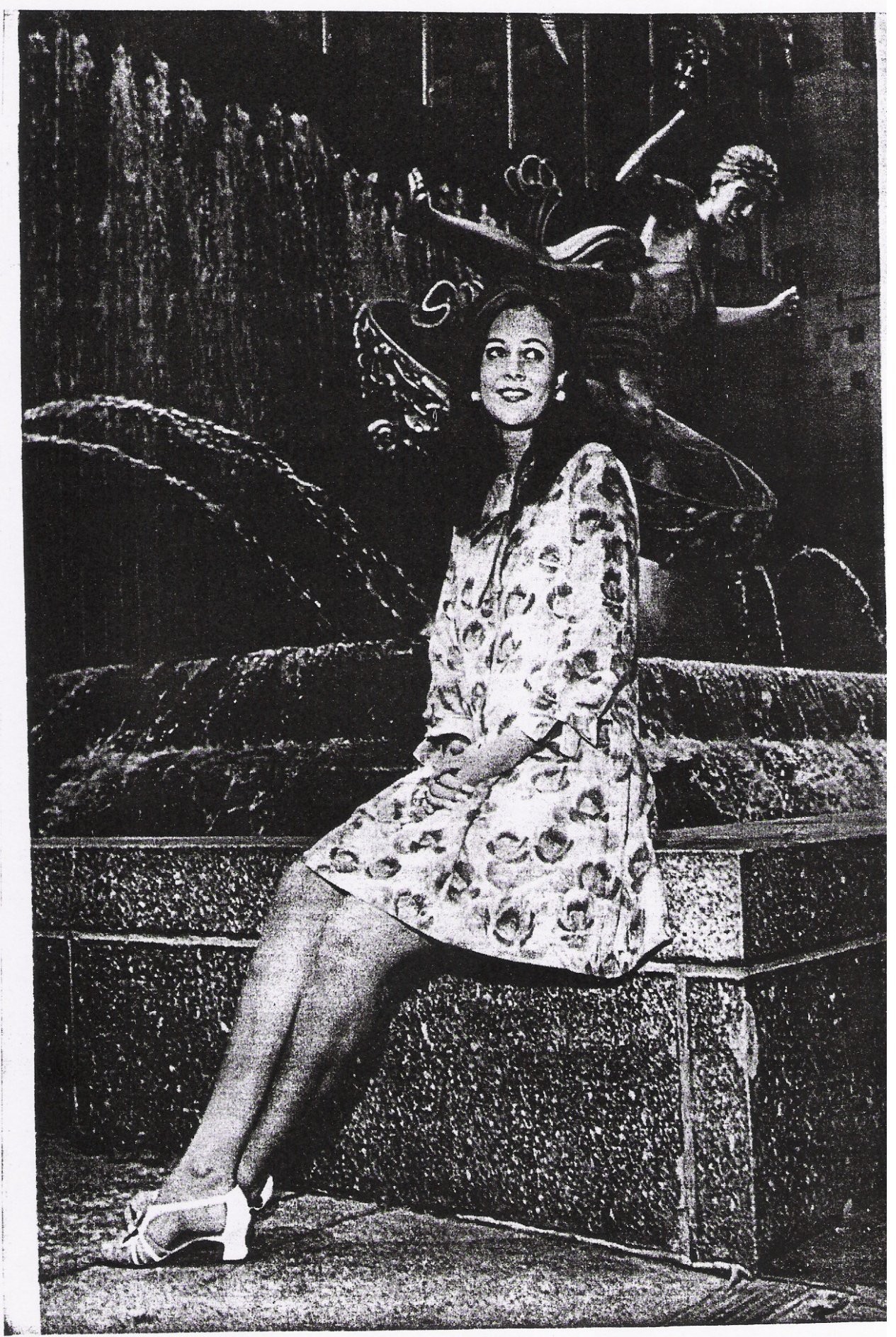


DO CANSAÇO DE MARTA, A ALEGRIA NACIONAL
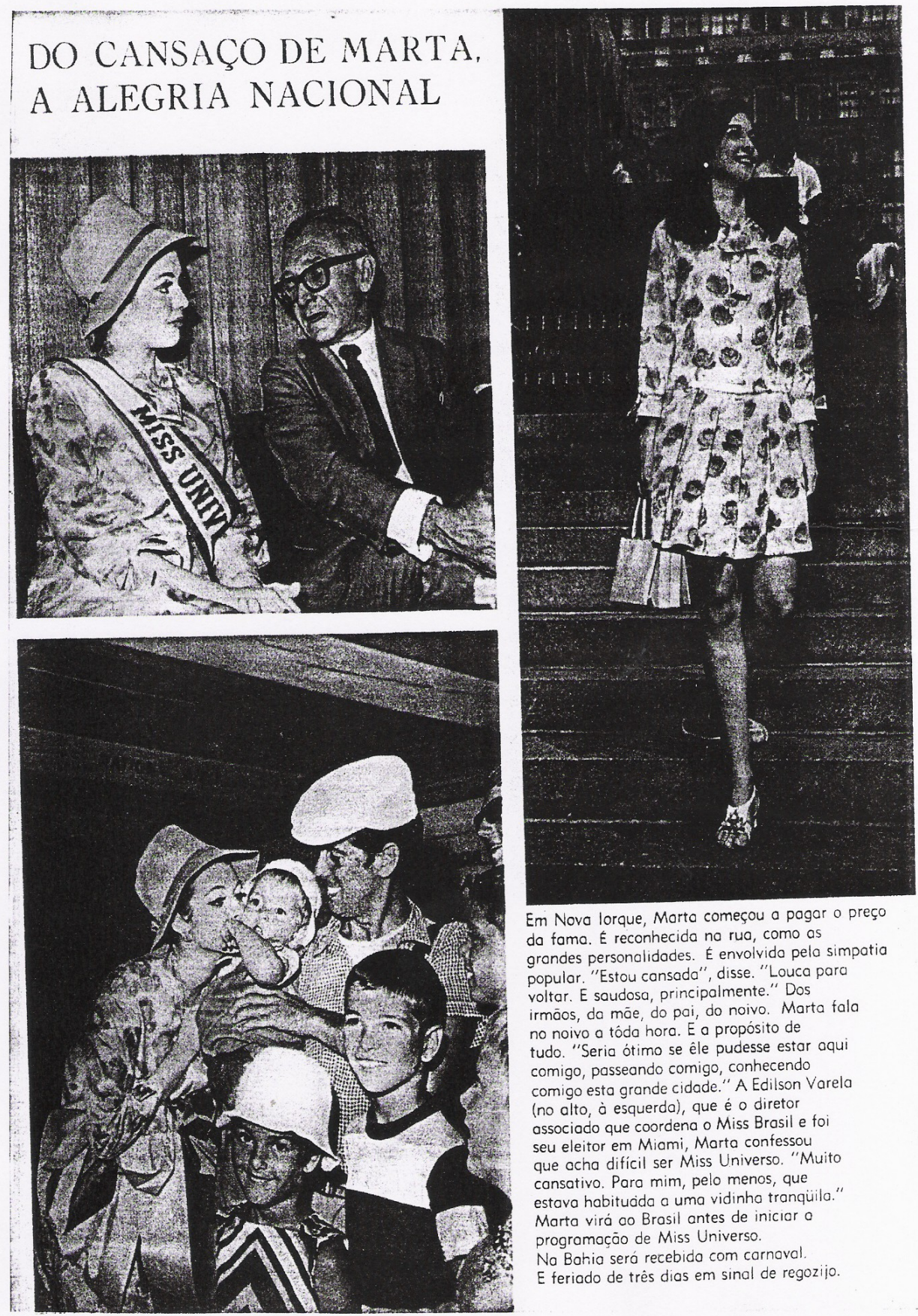

Em Nova lorque, Morto começou a pagar o preço do foma. E reconhecida na rua, como as grondes personolidades. E envolvida pela simpatio popular. "Estou cansada", disse. "Louca para voltar. E saudosa, principalmente." Dos

irmäos, da mäo do pai do noivo. Marta fala ir man, da má do pá ásito de tudo. "Seria ótimo se êle pudesse estar aqui tudo. "Seria otimo se ele pudesse estar comigo esta grande cidade." A Edilson Varela (no alto ò esquerda), que é o diretor associado que coordeno o Miss Brasil e foi asu ele am Miami, Marto confessou seu elítícil ser Miss Universo. "Muito que ocha dificil ser Melo menos, que cansativo. Para mim, pelo mentidinho tranquilo." estava habitudida a uma vidinho tranquila
Marta virá ao Brasil antes de iniciar o programação de Miss Universo.

No Bahio ser recebida com carnoval.

E feriado de três dias em sinal de regozijo. 


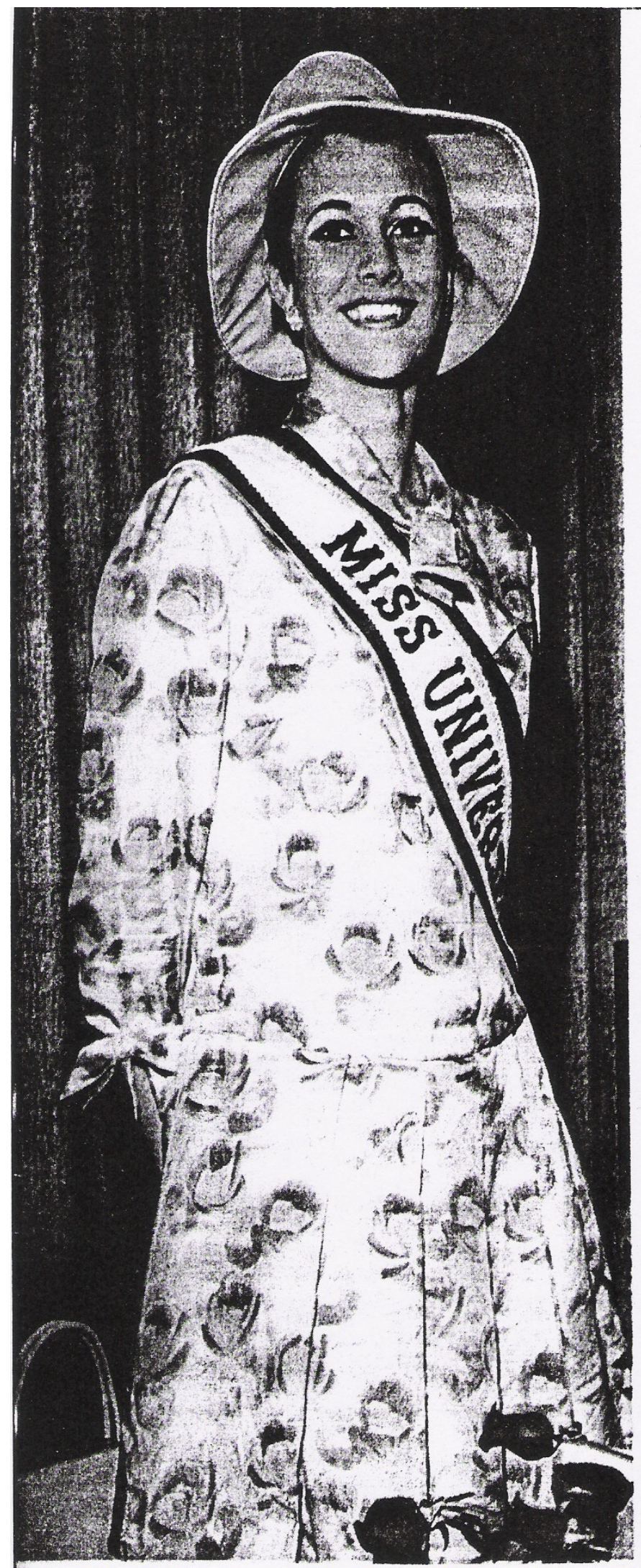

\section{DELA, O ENCANTO E SAUDADE}

"Todos são muito gentis. Adultos e crionças. Fazem-me parar na rua, conversam comigo, dizem coisas amáveis. Estou cansada, é certo, mas encantado, também." Marta tem sido muito simpática com a imprensa, inclusive com os fotógrafos, apesar do assédio que

The fazem. E mais simpática ainda com os fās Tem sempre uma palavra amável, um gesto de carinho. Näo há uma só pessoo em NI, das muitas que tiveram contato com ela,

que não elogie a sua gentileza, logo depois de elogiar a sua inegável beleza.

Marta é olegre, soudável, extrovertida. E um ótimo garfo. Come de tudo - e bem.

Adora refrigerantes e parece nâo ter sentido o tempéro americano, tão diferente dos mólhos e condimentos da sua Bahia. Aliás, no capítulo dos temperos, há umo saudade a somar-se à saudade das crioturas amadas: a do vatapá. Com bastante dendê e pimento, como mandam os melhores tratadistas da boa (e perigosa) cozinha baiana.

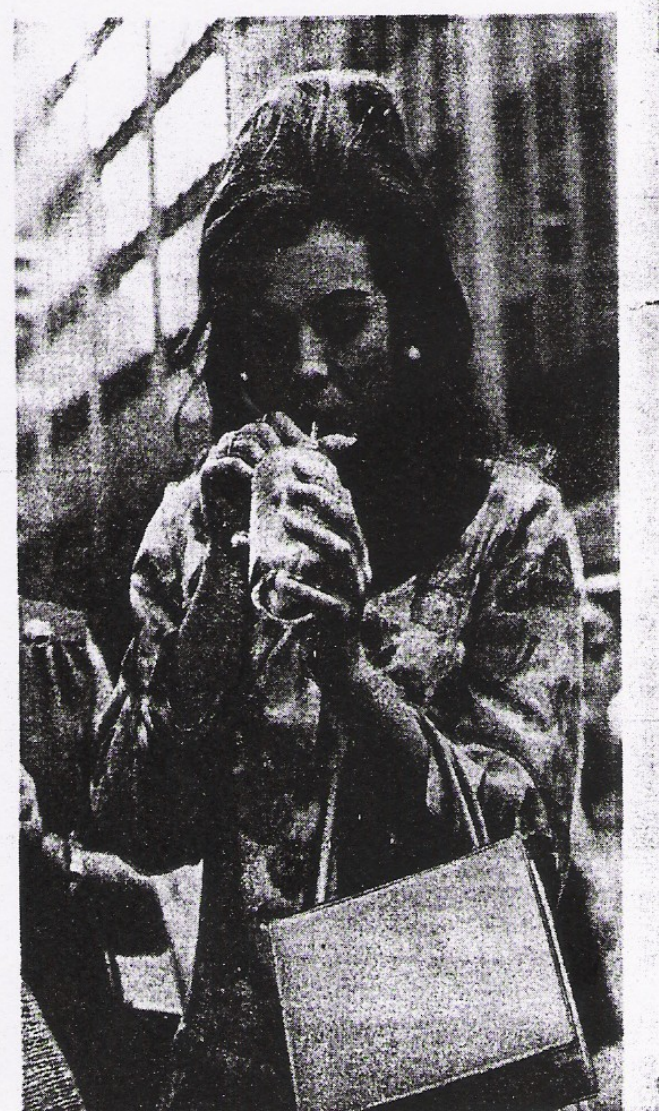




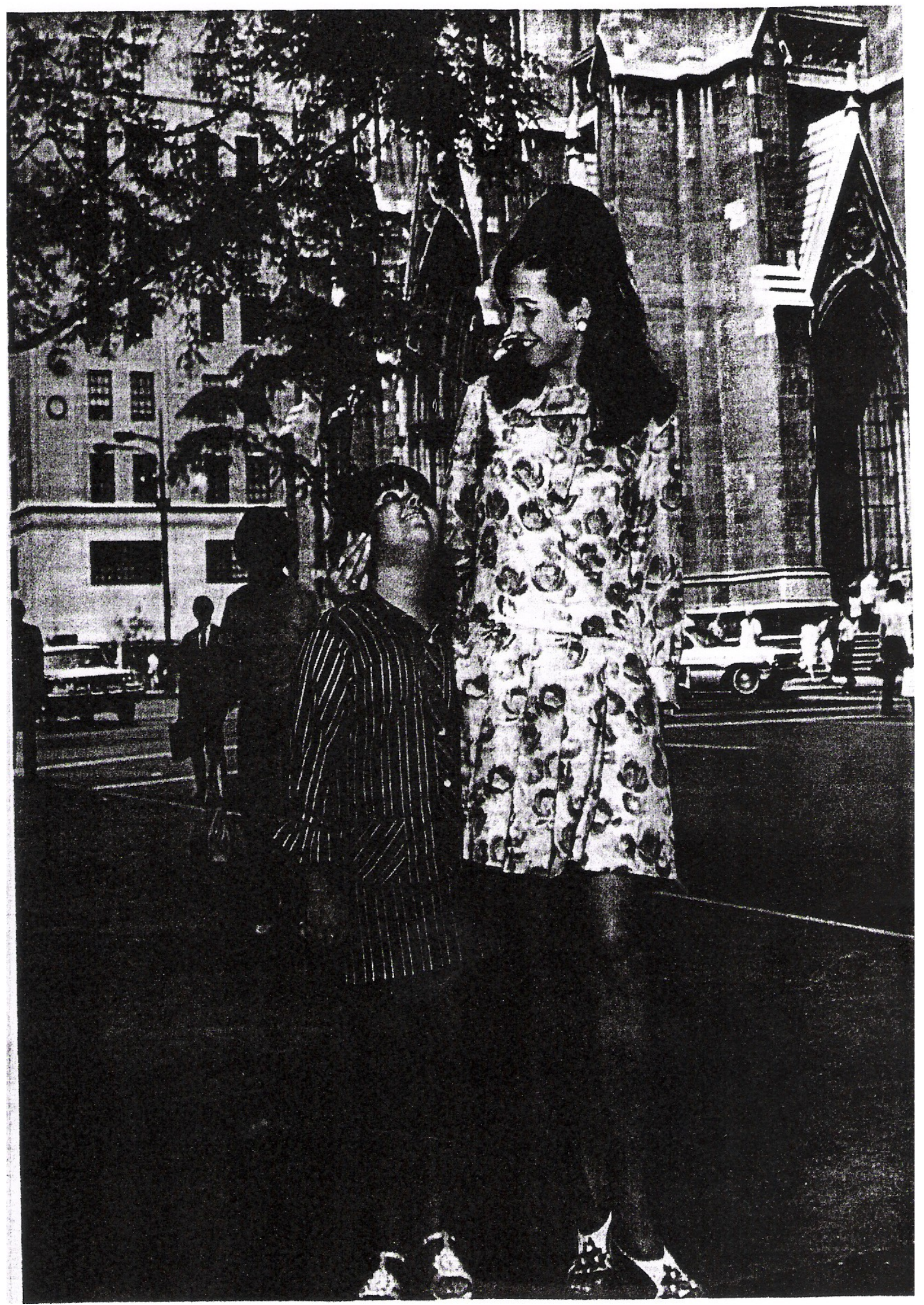




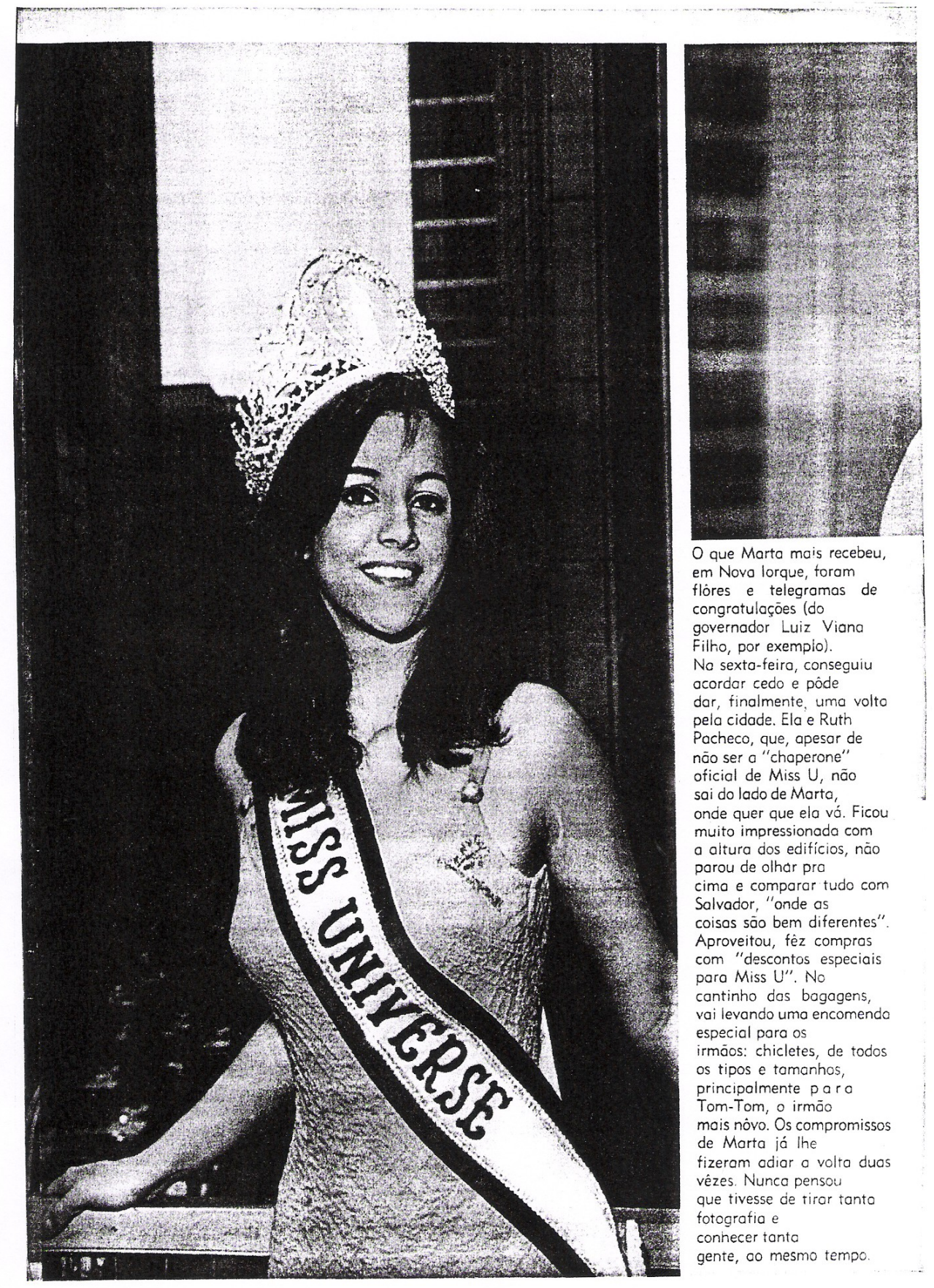



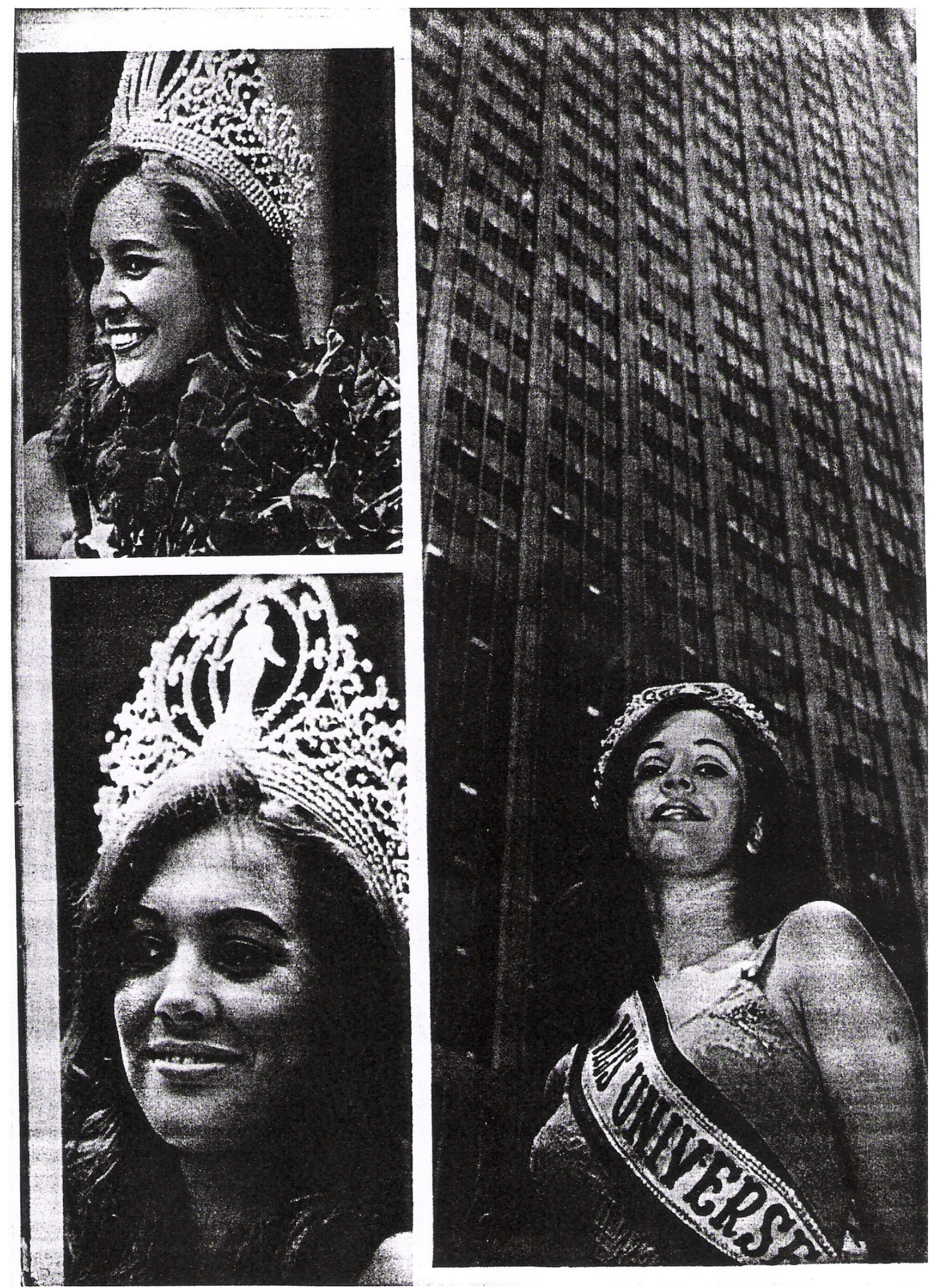


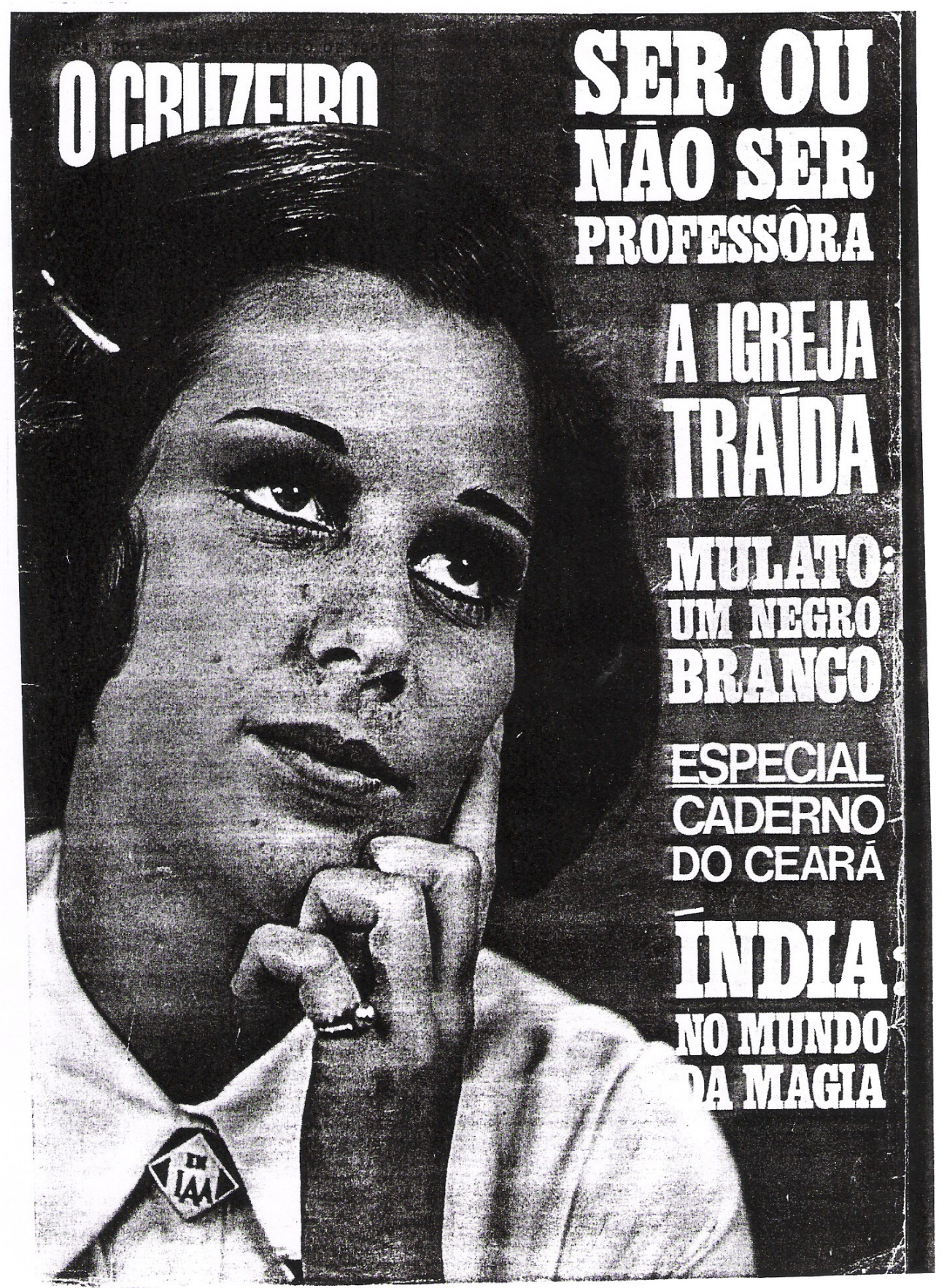



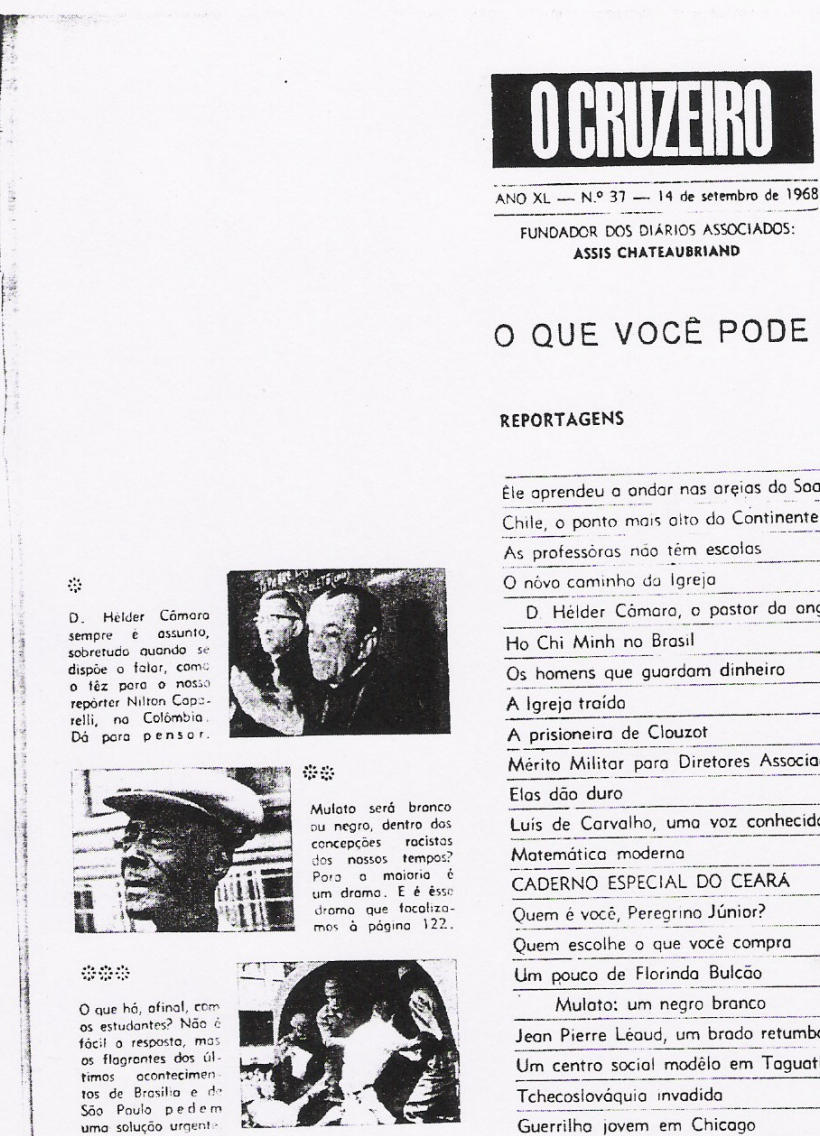

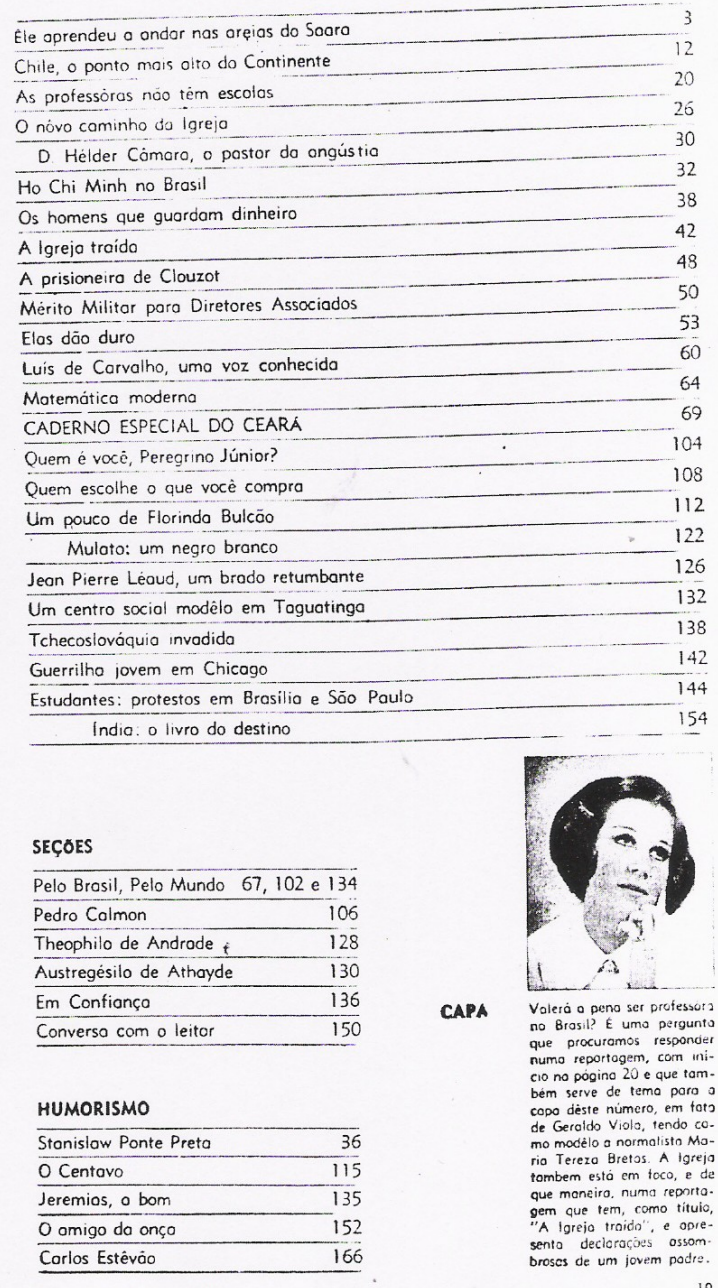




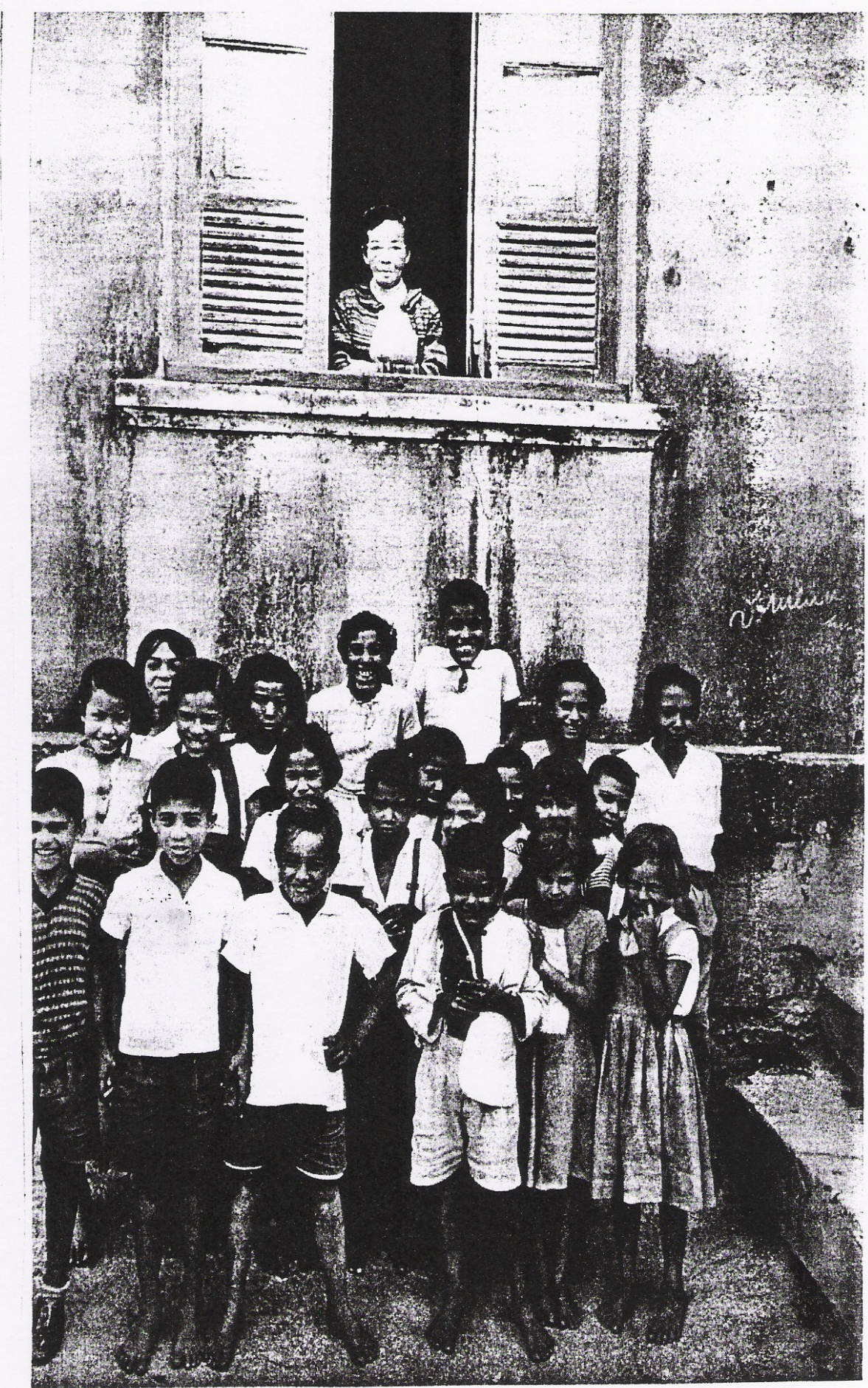



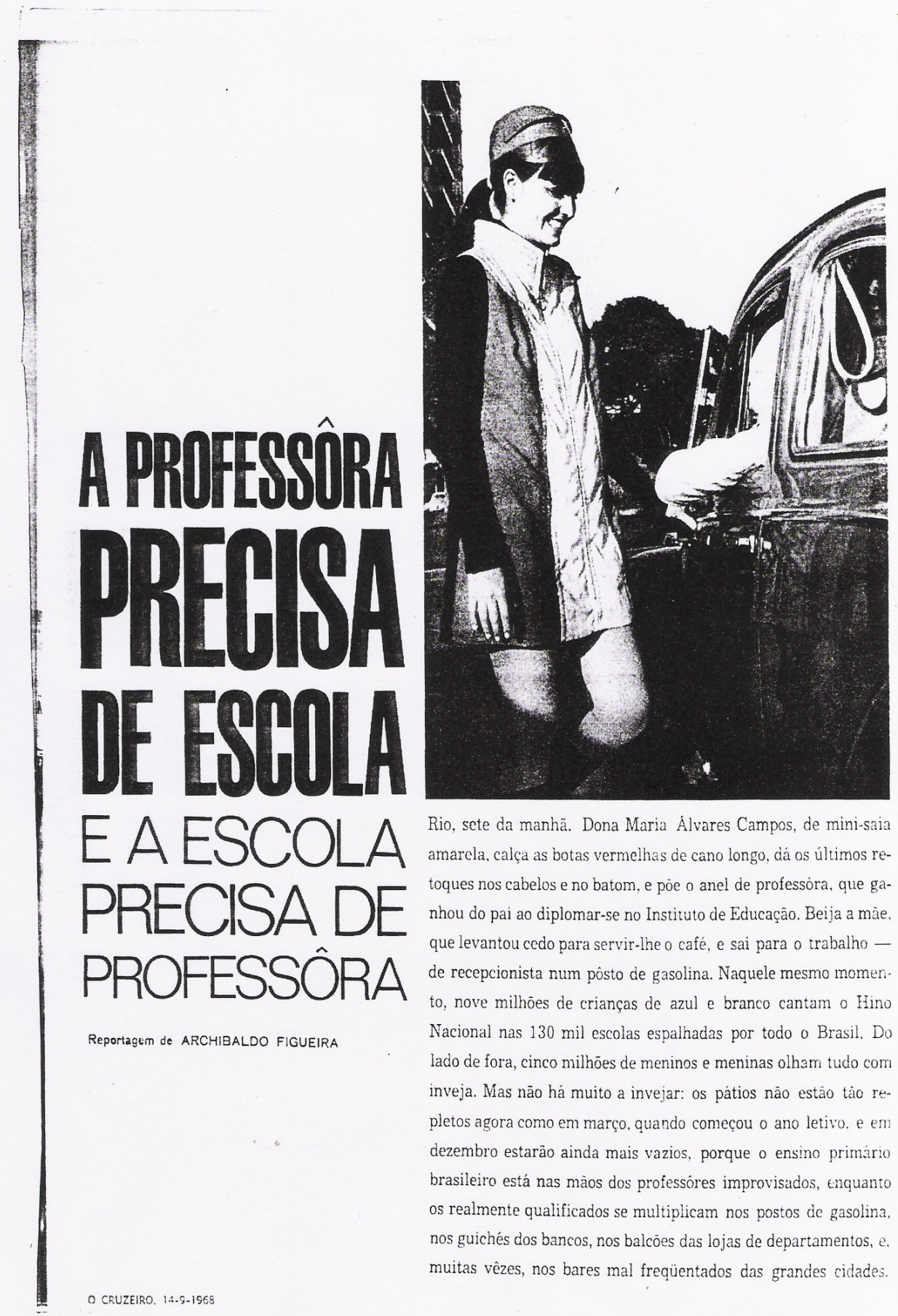

Rio, sete da manhã. Dona Maria Álvares Campos, de mini-saia amarela, calça as botas vermelhas de cano longo, dá os últimos retoques nos cabelos e no batom, e póe o anel de professora, que ganhou do pai ao diplomar-se no Instituto de Educação. Beija a màe. que levantou cedo para servir-lhe o café, e sai para o trabalho de recepcionista num pôsto de gasolina. Naquele mesmo momerito, nove milhōes de crianças de azul e branco cantam o Hino Nacional nas 130 mil escolas espalhadas por todo o Brasil. Do lado de fora, cinco milhōes de meninos e meninas olham tudo com inveja. Mas não há muito a invejar: os pátios não estão tảo repletos agora como em março, quando começou $o$ ano letivo, e em dezembro estarão ainda mais vazios, porque o ensino primário brasileiro está nas mãos dos professôres improvisados, enquanto os realmente qualificados se multiplicam nos postos de gasolina. nos guichés dos bancos, nos balcôes das lojas de departamentos, e. muitas vêzes, nos bares mal freqüentados das grandes cidades. 


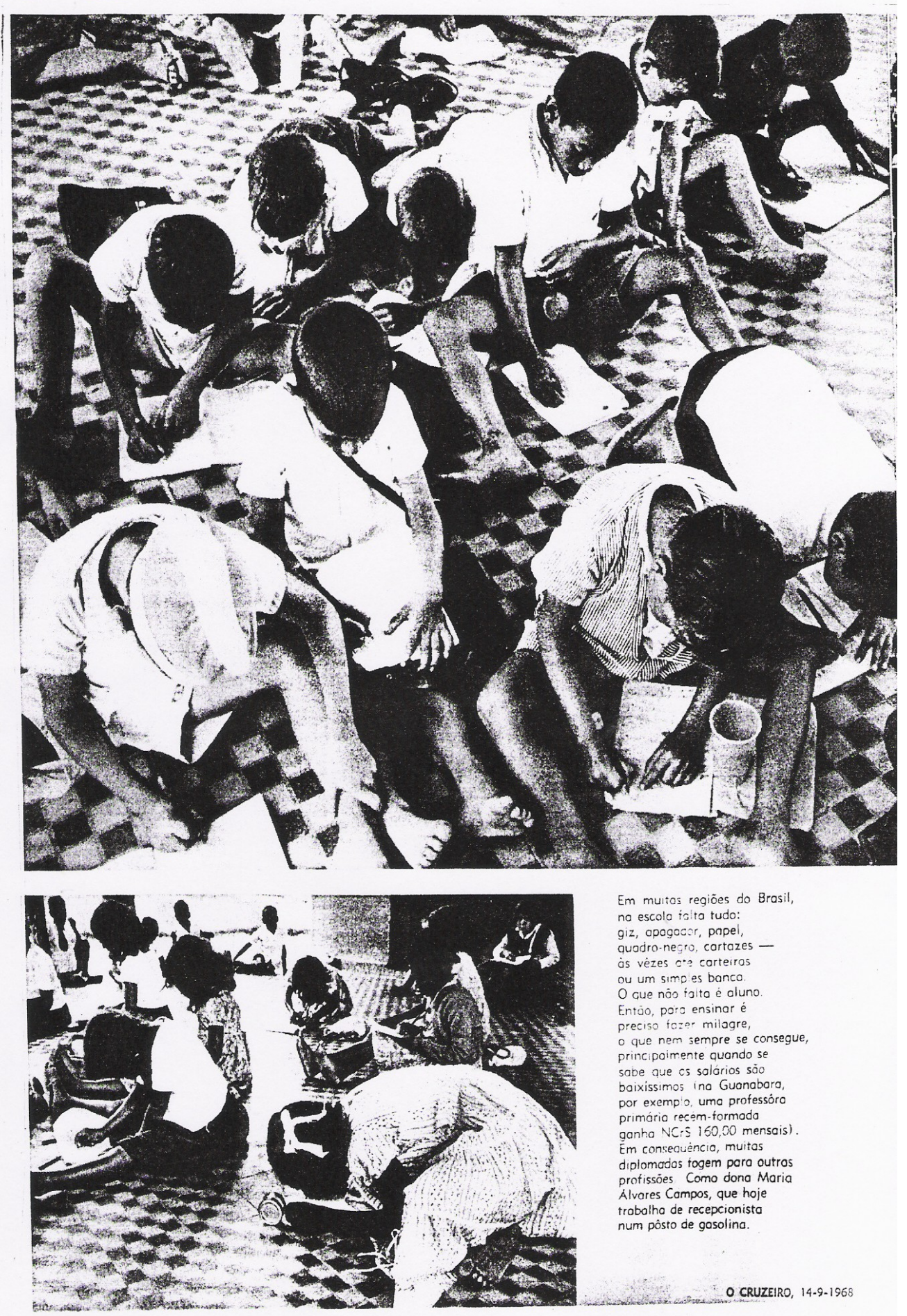




\section{nota zero para o ensino primário}
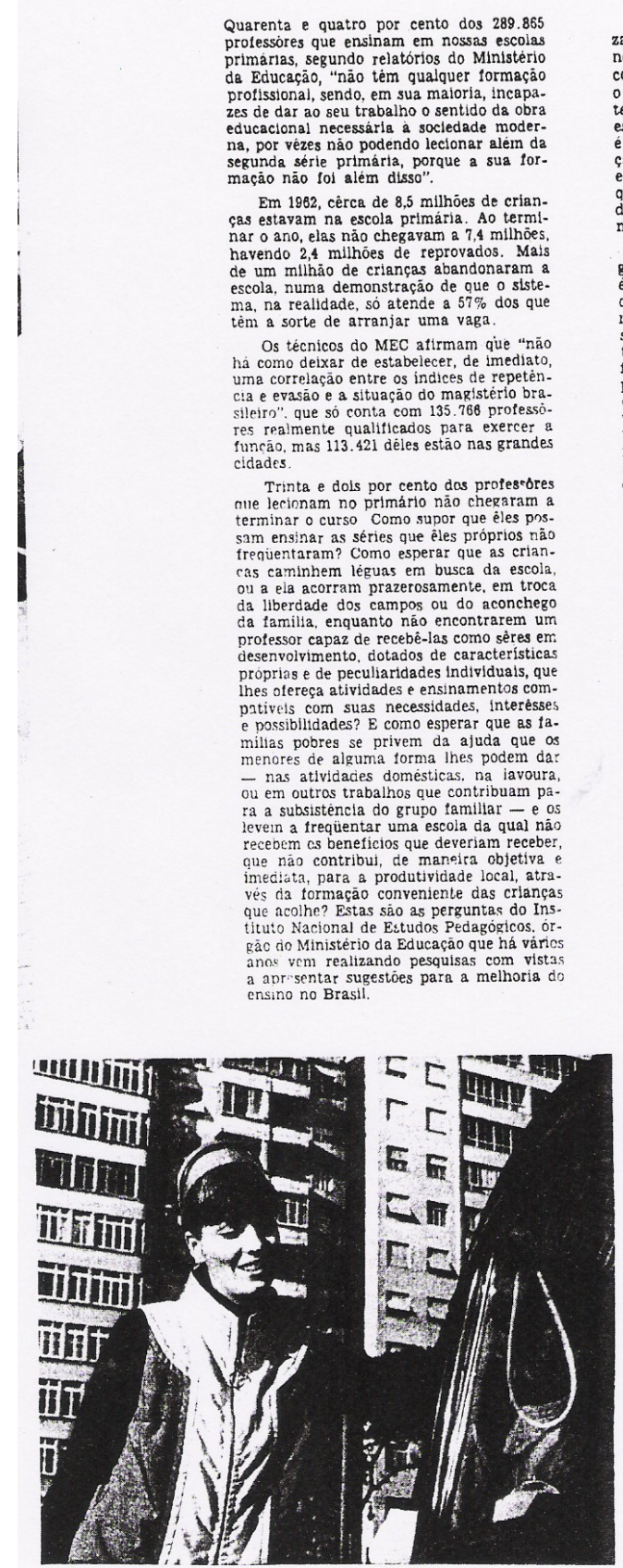

Nos grandes centros - onde a escolari zaçâo, boa ou má, é, por si mesma, uma necessidade sentca, compeliç de relençāo embora a escola não tenha a eficiencia que deveria, nem seja estreitamente Ligada às necessidades locais, e maior, e não são raros os casos de crianças que chegam ao imso curso pro tempo que serlo necesserio segundo os técnicos do INEP, em determinados Estados a primeira série primária é feita em quatro anos. O Instituto Nacional de Estudos Pedagógicos atirma que "a qualidade do ensino é superior nas reglóes onde se pode contar com professores formados em cursos normais de grau colegial e que realizaram curtos de apericicoamento elas que seria licito fazer as escolas em que. de modo geral. o professor atua, não sảo tão bem atendidos como deveriam. Entre as várias causas relevantes, duas se deda as arado e taiha no sletema educactonal, que implicam no abandono do professor a si mesmo, a partir de sua diplomacáo e por tóda a sua vida proissstonal. e em latta de estim

tote exatamente o caso da Cuanaba. ra, onde milhares de Maria Alvares verifica sava de um pesadelo na realidade da professora.

As duas medidas

Maria Alvares Campos tinha doze anos quando terminou. no no, ocurso de admistiu que não poderta continuar os estudos, a menos que fizesse o ginásio por conta do Governo. E, foco de um problema de tam! lia. teve seu destino decidido pela propria família: os tecricos do INEP artrmam que pass, e apontam uma pesquisa realizada $n$ Guanabara, provando que, em $42 \%$ dos casos. as moças se matricularam na escola normal por influencia da tamilla.

Decidido que Maria Alvares Campos iria para a escola normal, ela, durante um ano inteiro, frequentou um cursinho preaulas aos sabados, domingos, feriados e até mesmo no Natal. E, em janeiro, com outras dez mil, concorreu a uma das duas mil vagas abertas. fazendo um

Aprovada e classificada, matriculou-se no primeiro ano do 10 ciclo, que correspon. mats uma vez, tomar a decisáo. A despeito das pesquisas de Luis Pereira e Apareclda Joly Gouveia, segundo os quals de 53 a $61 \%$ dos alunos do normal ná tem o propasito de trabalhar, fica deciefessora. "porque na Gusmabars todos os formandos sáo aproveitados, e com as melhores salários de professora do Brasil"

Maria Alvares Campos aceita tudo. 0 INEP explica que "â situação se prende, em grande parte, a um problema pstcologico, porque antes de 18 anos as escolnas aind tentativ" $E$ sos trancos e barrancos, Marla Alvares Campos chega a. $2 .^{\circ}$ ano do último ciclo Normal. Aos 18 anos, a uitima sérte. Sonha com o vestido de baile, os con. vites para a lormate mesmo com o salório de NCrs 130.00 mensais que o Estadn the dará para ir diariamente à zona rural lecionar durante auatro horas e voltar para casa. onde corrigira provas e trabalhos duà preparaçáo da aula do dia seguinte. 


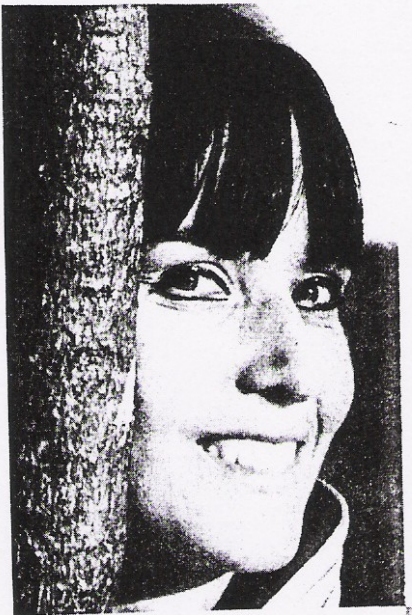

Mario Alvares Campos. Diploma de rofessoro; funçáo de recepcionista

Exatamente aj, no último ano do curé exatamente aj, campos descobre a ealldade: que para dar tormaçáa a uma rtança, tetá de morrer de fome, pedir caonz, tirar do pai o pouco que ele náo tem. or demagogia ou real necessidace. o Estaro decium alunas do último no do Curso Normal sao chamadas a lectonar ... "para cue fiquem hem preparadas" Mas na escoia falta tudo: giz, apagador artazes, papel, mimeografo. Sem este maerial na podera a pontos para a aprova :äo Năo terá o diploma. Apesar de o Esado pagar-lhe uns NCrs 2.00 por dia d? rabalho, ela gasta tudo na conduçao. E ecorre ao pal. que Ja ganha mal, para suJir as derancos andando qullometros sob jol ou chuva carregando enormies cartuchos le cartolina pintados até tarde da noite. nadrugada adentro. Chega o $1 \mathrm{~m}$ do ann 1 festa de formatura, o discurso do parainfo, o abraço do Governador. o beljo inamam-ns para "escolher" a escola. E narço. mandam-na para a que menos queia. e so $\mathrm{em}$ abril pagan-lhe o onmelro sa Glvares campos com o dinheiro compra 4lvares Campos. coin o dinheiro, compra zglhar como recepclonista de posto de gasolina em junho.

O caso de Marla Aivares Campos llustra jem a aftrmacào do INEP de que o continzente de $30 \mathrm{mil}$ professores oferecidos mals näo catura o mercado Justifica tamJém o fato de br rem a ser nomeados ou contratarios em muitos Estados, especlalmente nos sistema: municipals, por metros crite nos politicos, sem adidas tendentes a assecurar a apresenta ilficuldades em encontrar professôtes nue aceltem trabahar em determinadas regió de menos recurms. com o salario due thes Tal salario e com freaiência insuficient pars atender as syas despesas. apenas uma quota complementar no orca. mento da familia e não permitindo independencis finmeils en ao professor.

Os professôres formados fixam-se nos locais once estão as escolas de formação do magisterio $\ell$, muitas vézes, não aceitam sede dos municipios proximos. Assim, o mercydo de trabalho ê reduzidissimo em burbana e $91 \%$ na rurali.

O professor quando acelta trabalhar nas zonas rurais. como fase de provacão, ambiciona chegar aos centros maiores, fajam au as pedides de remocáa atinPaulo onde as remprosos só são permitidas do maglstério se remove cada ano. A situacāo ainda é mais grave em Estados que permitem a remoráo durante o ano. com ancas i lizcola $e$ consegientemente atendimento escular. "Em tais casos -.. diz - INEP - predomina o interésse pessoal do professor sobre o interesse do erisino. Não raro. classes sán fechadas durante o anopor dos para esculas do interlor sáo imedinta. Parana. os leipos consutuem a matros. No professorado t39 cona zona urbana e sude dois em dols anos, praticamente metade

mente transferidos, em comissão, para a capital." ascensão dos leigos se devern, principalmente, ao fato de ser a remuneração do maglsterio insignificante, levando a profissão da pagam ao professor titulado menos que 0 salario-minimo, e municipios onde a remuneração não passava de dots cruzeiros novos $e$ cinauienta centaras me agós-

Em 1963. no Nordeste, quando o saláriocruzeiros antigos, havia professores recebendo 200 cruzeiros antigos por mês. Hoje, na Guanabara, uma professôra recem-forais. Tals salários, não dando an professo independéncia financeira. determinam que éle fique presso a constelaça familiar. da qual depende para manter-se. Fu se de un jado alificando a admissão de incompetentes.

Problemas da mulher

O prrfessorado primário, no Brasil, é uma

Nas 130 mil escolas esoalhados pelo Brasil, estudam 9 mithöes de criancas. Cinco milhöes

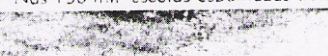
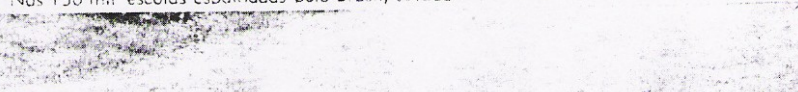

\section{$y$}

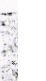
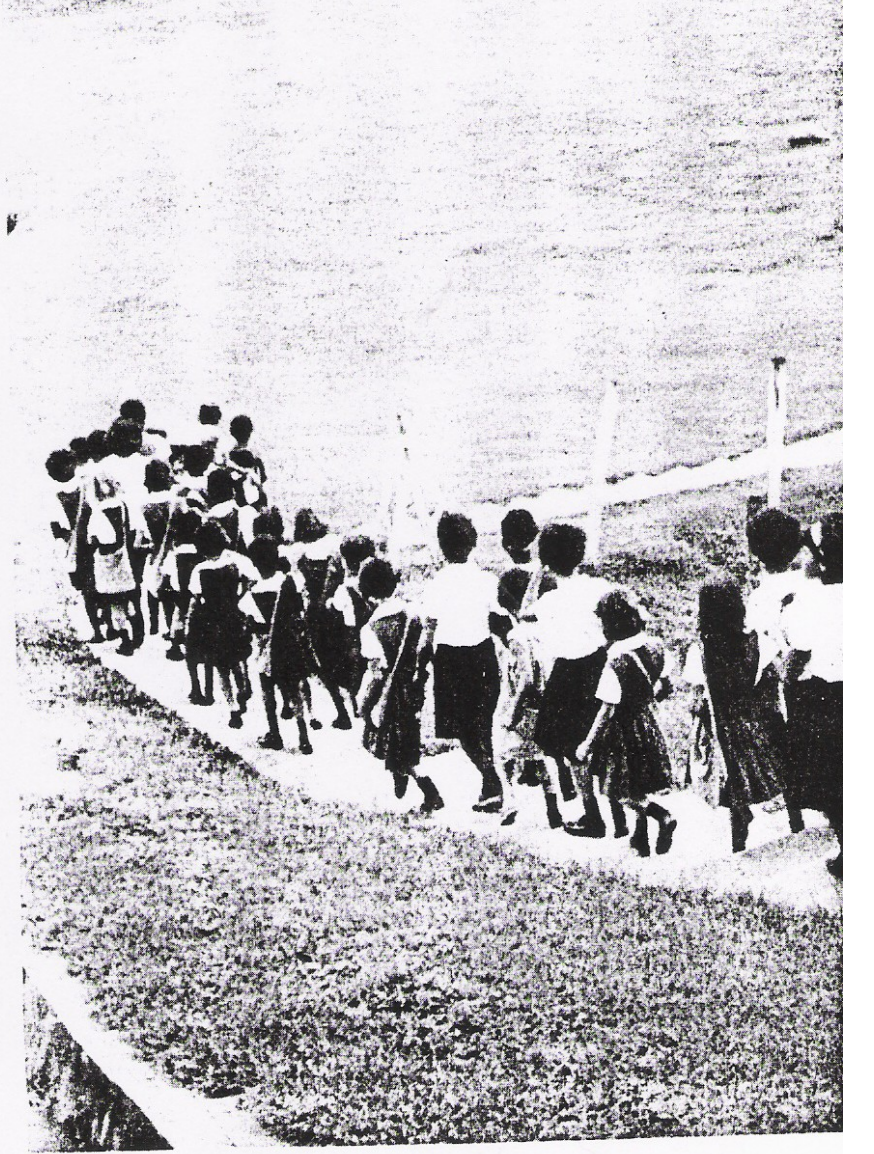
por cento do magistério são constituídos por homens. As mulheres, em geral, comportam-se timidamente quando têm de se dessentam os requilsitos de segurança e contôrto a que se acham habituadas. As normalistas de $2.0^{\circ}$ ciclo recebem os seus diplo. amililas tèm como inadequada para o tra. balho distante do lar, o que piora a situaçäo. Assim, as mbcas, monidas pela pressão Cemiliar, pretendem ao mesmo tempo tra. balhar - para nâo perder o emprêgo pú. Independéncia - e entrar para uma facul. dade, cujo diploma the permitirla uma mudança de status econômico e social. Baseados nestes argumentos, sente de incentivos que contribusm pars encaminhar elementos masculinos ao magistério, o que seria de grande importância, especialmente para a 5 .a e a ba ser

Alertam os técnicos que "apesar de haver desperdicto de professores Icrmados, réde de ensino normal conthua a se ex atenda às necessidades reals. Os cursos normais surgem aqui e all, ora atendendo criterios po tho de escolarizar a mulher brasileirs. arrentas a criaco de novas escolas nor-

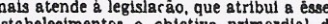
formar protessores pera as escolas primánas".

Anallsando as falthes do ensino os tec nicos do INEP afirmam ser "Impressionante 8 falta de relacionamento entre o program de preparasáo profisstional do professor e trabalho que ele deve realizar na escola prmária" Uma pesquisa eseluada recentminante é a exposicáo oral, deixando-se de lado os debates, as excursoos, as entrevista os estudos da comunidade e as pesquisas de um modo geral. Nas escolas de cinco dos riênclas nas aulas de Clincias. Os alunos estudam Psicologia e Sociologla, mas nã adquirem atitude psicológica e sociliógica adequada para enfrentar, no futuro, proble. mas concretos, Individais e coletlvos, como milis e a eacola 0 professor $a$ aluno, vida intelectual e a vida afetiva, os eleitos da personalidade do professor. Indagando. se da opiniáo dos professorand 's sobre
programa de Matemática da escola primá rla, vinte por cento déles confessaram ní conhece-10, tendo esta percentag.

E. taxativamente, após a pesquisa, 0 Instituto Nacional de Estudos Pedagóglcos malistas assim formados e que ingressa no magistério Inicia a carreira despreparada, resultando certo desanimo e aprendlagem por tentatlvas e erros; o que se vem ofereto ná á vels dos alunos ou às exigências atuals $d$ proilissäo; a tonica do ensino nas escolas tormaçao do magisterio alnda cismo, há um alastameducação primária al tamente seletiva Se não queremos perder grande parte de nossos estorços, é preciso que se faça um planejamento da formaça de professores dentro de uma nova mentada ed learao primárla seralmente desoonhecidos dos protessóres"

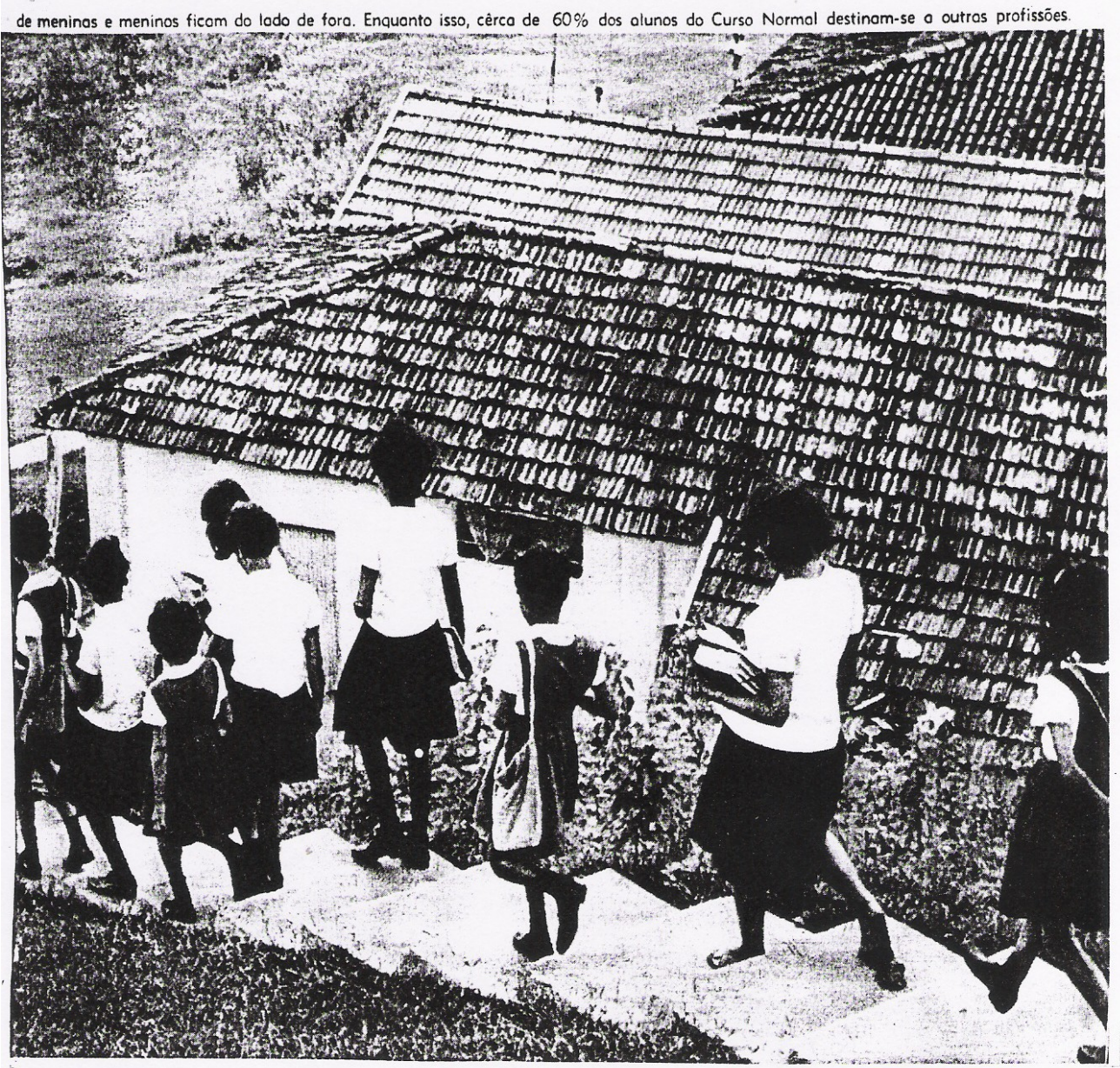

